UNIVERSIDADE DE SÃO PAULO

MUSEU DE ARQUEOLOGIA E ETNOLOGIA

PROGRAMA DE PÓS-GRADUAÇÃO EM ARQUEOLOGIA

EMERSON NOBRE DA SILVA

\title{
OBJETOS E IMAGENS NO MARAJÓ ANTIGO: AGÊNCIA E TRANSFORMAÇÃO NA ICONOGRAFIA DAS TANGAS CERÂMICAS
}

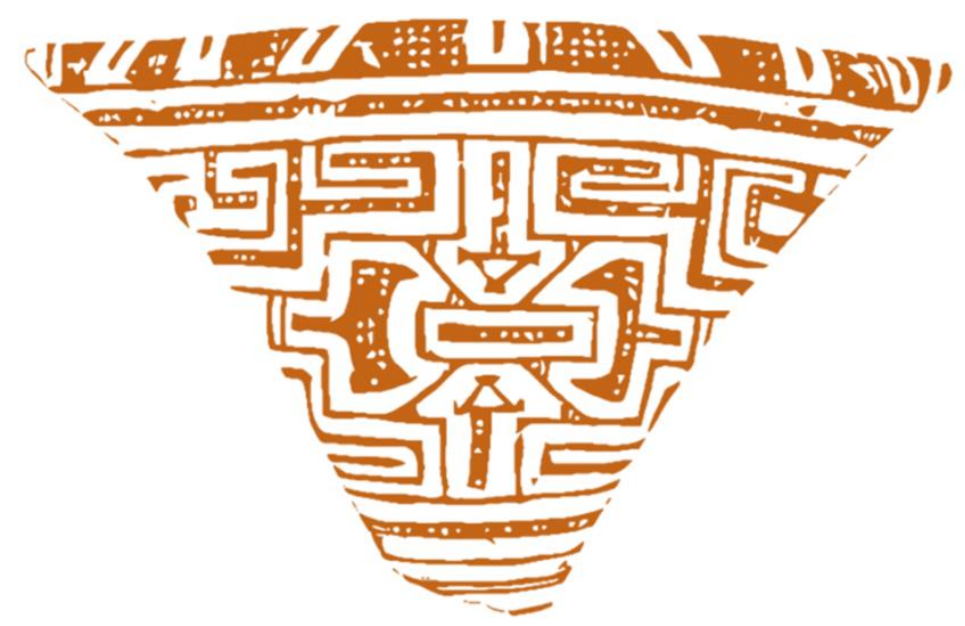

São Paulo 


\section{OBJETOS E IMAGENS NO MARAJÓ ANTIGO: AGÊNCIA E TRANSFORMAÇÃO NA ICONOGRAFIA DAS TANGAS CERÂMICAS}

(Versão corrigida. A versão original está disponível na biblioteca do MAE-USP)

Dissertação apresentada ao Programa de PósGraduação em Arqueologia do Museu de Arqueologia e Etnologia da Universidade de São Paulo para obtenção do título de Mestre em Arqueologia

Área de Concentração: Arqueologia

Orientadora: Prof. ${ }^{a}$ Dr. ${ }^{a}$ Maria Cristina Nicolau Kormikiari Passos

Linha de pesquisa: Arqueologia e Identidade

São Paulo 
À Anita e Armando 


\section{Agradecimentos}

Agradeço às muitas pessoas e instituições que contribuiram para o desenvolvimento da pesquisa aqui apresentada.

À CAPES (Coordenação de Aperfeiçoamento de Pessoal de Nível Superior) pela bolsa de pesquisa que fomentou este trabalho.

À professora Dr. ${ }^{a}$ Maria Cristina Nicolau Kormikiari Passos por me acolher como seu aluno, pelo incentivo em seguir na Arqueologia e, sobretudo, pela confiança.

À Dr. a Cristiana Barreto agradeço por todo o apoio e instrução para desenvolver esta pesquisa durante estes três anos e meio. Agradeço, especialmente, pela ajuda na redação dos capítulos e por toda a paciência, sobretudo, neste último ano.

Ao professor Dr.․ Eduardo Góes Neves por todo o incentivo ao longo dos anos e também pelas sugestões na banca de qualificação.

À professora Dr. ${ }^{a}$ Fabíola Silva pelo direcionamento e pelas úteis sugestões durante a banca de qualificação.

Aos membros da banca de defesa, professora Dr. ․ llana Seltzer Goldstein e professor Dr.․ João Darcy de Moura Saldanha, agradeço pelos comentários e sugestões que enriqueceram ainda mais este trabalho.

À Sílvia Cunha Lima pelas conversas sobre as cores e queima das

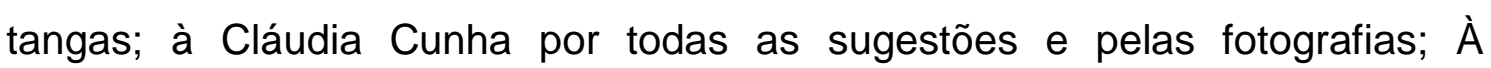
professora Dr. ${ }^{\text {a }}$ Márcia Arcuri por todas as sugestões. À Denise Schaan pela gentileza em compartilhar as suas fotografias e pela disposição em responder às minhas dúvidas.

A todos os funcionários do MAE, especialmente ao pessoal da Seção Acadêmica, sobretudo, à Aline, Regina, Karen e Cláudia, sem as quais a resolução dos trâmites da vida acadêmica seria mais complicada. Aos funcionários da biblioteca, com agradecimentos especiais à Monica, Hélio, Alberto e Washington.

À Carla Gibertoni e Cristina Demartini por toda a paciência e apoio durante toda a minha pesquisa. À Sandra Torres, Francisca Figols, Ana Carolina, Regivaldo e Paulo. 
Agradeço às equipes que me atenderam nas instituições nas quais eu analisei material. No Museu Paraense Emílio Goeldi, à Maura Imázio, à Helena Lima e à Camila. No Museu do Estado de Pernambuco, à Elvira Blásquez, à Adriene e ao Pablo. À Elvira, sou grato, especialmente, pela atenção dispensada nos meses anteriores à minha pesquisa e também nos meses posteriores, fotografando, gentilmente, os materiais solicitados. No Museu Nacional, à professora Dr. ․ Rita Scheel-Ybert, à Angela Rabello, à Mariana Ferreira e ao Leonardo de Azevedo.

Agradeço também à Cássia Rosa por intermediar o meu pedido de autorização de uso de imagens junto ao Sistema Integrado de Museus e Memoriais, em Belém. À equipe do Museu do Instituto Histórico e Geográfico de Alagoas, em Maceió, pela cordialidade em me enviar as fotografias dos materiais solicitados.

Agradeço também aos amigos que, de algum modo, contribuíram para o desenvolvimento desta dissertação. À Erêndira Oliveira, pela análise dos fragmentos da coleção do MAE, pela leitura e sugestões no meu texto, por todas as conversas ao longo de todos estes anos, desde que ainda estávamos no "limbo"; Mariana Cristante, grande amiga, que compartilha comigo o primeiro campo, quase uma década atrás, pelas sugestões no meu texto e pelas longas conversas; Marcony Alves, pelas incontáveis leituras dos meus capítulos, sugestões, incentivo e longas conversas; Rafael Lopes, Laura Furquim, Arkley Bandeira, Jennifer Watling, Meliam Gaspar, Joanna Trofflard e Alexandre Recuaro.

Aos amigos que fiz na Arqueologia: à minha gêmea Letícia Ribeiro; aos meus leoninos preferidos Marina di Giusto e Maurício Silva; aos queridíssimos Viviane Wermelinger e Arkley Bandeira; À Marjorie Lima, Letícia Correa, Thiago Kater, Eliane Chin, Jaqueline Beletti, Duane Motta, Guilherme Mongeló, Rafael Stabili, Jessica Cardoso, Nicolás Batalla, João Augusto Silva, Carollina Kesser, Camila Diogo, Caroline Caromano, Leandro Cascon, Glauco Constatino, Rodrigo Lima, Felipe Perissato, Cláudio, e muitos outros que provavelmente não mencionei. 
À Cleide, Débora, Danilo, Luciano, Sarah, Giovanna e Anderson pela compreensão durante estes três anos e meio. Às minhas tias Odeth e Bena e às minhas primas, Gisele e Débora.

E por fim, ao Fernando, não só pela compreensão, mas também por toda a ajuda durante todos estes anos. 
(...) "seu problema jamais foi a semelhança e a forma humana, mas o modo de representar a transformação, de transpor em imagens o fluxo transformacional que caracteriza os seres poderosos. A resposta a este problema não podia ser encontrada na reprodução a mais exata possível das formas naturais; mas, ao contrário, era preciso buscá-la na geração de imagens as mais complexas e paradoxais possíveis, nas quais as identidades estão encaixadas e os referentes são múltiplos"

(Fausto, 2013:328). 


\section{Resumo}

Esta dissertação está centrada no estudo da iconografia da cerâmica marajoara, mais especificamente, na iconografia das tangas cerâmicas pertencentes a diversos acervos e coleções, com o objetivo de refletir sobre figuração durante a fase marajoara. Partindo de uma abordagem que integra Arqueologia, Antropologia da Arte e Etnologia, compreendemos as tangas enquanto objetos de composição, transformação e fabricação corporal, o que também permitiu identificar, em sua iconografia, uma forma de conceber imagens e corpos caracterizada pela integração de figuras aludindo a diversos seres e suas partes anatômicas, e também pela utilização de recursos gráficos que sugerem transformações corpóreas. Assim, as características expressas nesta iconografia foram interpretadas como uma forma de materializar princípios cosmológicos referentes à transformabilidade dos corpos, característicos das sociedades ameríndias, que colocam a transformação corporal como o centro de suas preocupações.

Palavras-chave: Fase marajoara, tangas, iconografia 


\section{Abstract}

This dissertation focuses on the study of the iconography of marajoara pottery, specifically on the iconography of ceramic tangas, to reflect on figuration during the marajoara phase. This work benefits from an approach that integrates Archaeology, Anthropology of Art and Ethnology, enabling us to understand the tangas as objects of composition, transformation and bodily fabrication, and to identify in their iconography a way of conceiving images and bodies, which was characterized by the integration of figures alluding to diverse beings and their anatomical parts, as well as the use of graphic resources that suggest corporeal transformations. Thus, the characteristics expressed in tanga iconography were interpreted as ways of materializing cosmological principles regarding the transformability of bodies, typical of societies that place body transformation at the center of their concerns.

Keywords: Marajoara phase, tangas, iconography 


\section{Sumário}

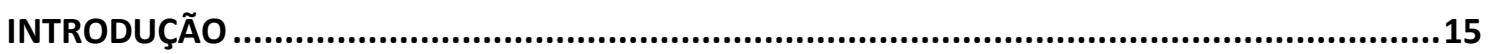

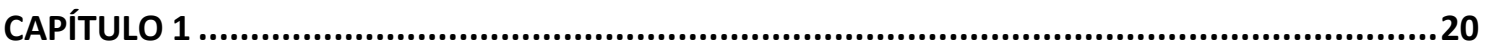

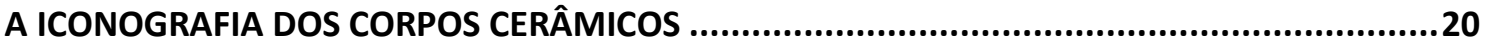

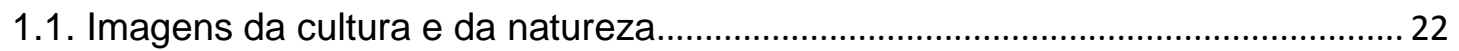

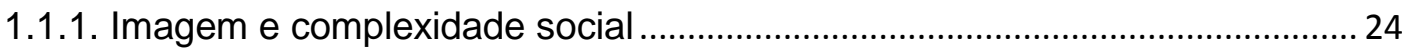

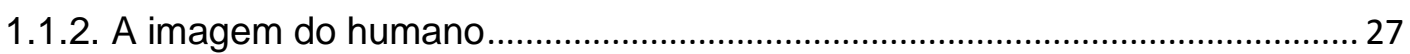

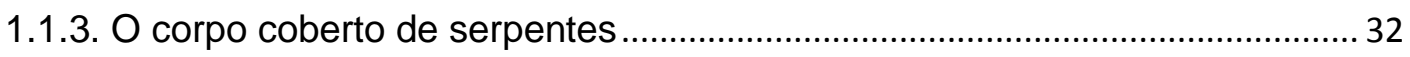

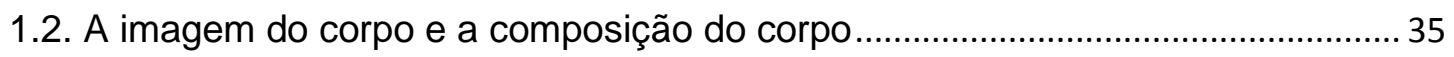

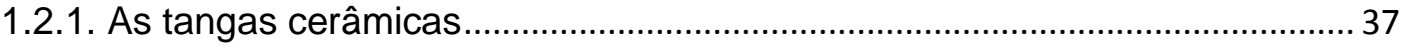

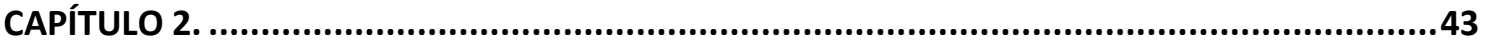

AGÊNCIA E TRANSFORMAÇÃO NA ARTE

2.1. Arte e Agência no mundo ameríndio ........................................................................ 45

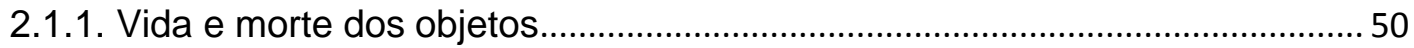

2.2. Anatomias artefatuais: corporalidade na Amazônia indígena ..................................55

2.2.1. A transformabilidade dos corpos e das formas ............................................... 58

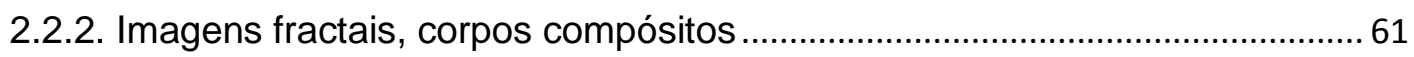

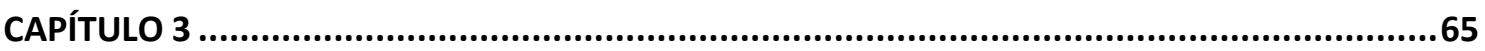

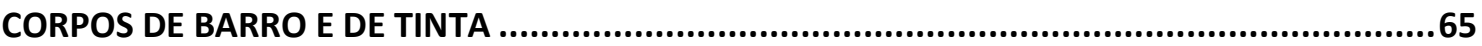

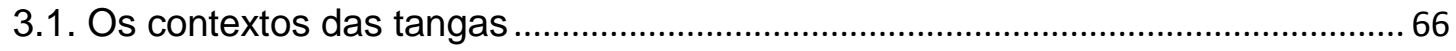

3.1.1. A distribuição das tangas com grafismos e das tangas monocromáticas .... 77

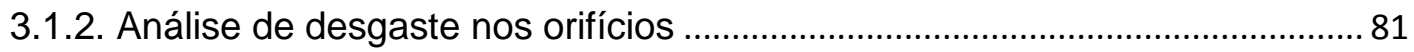

3.2. Os corpos pintados e a paramentação do corpo ................................................... 88

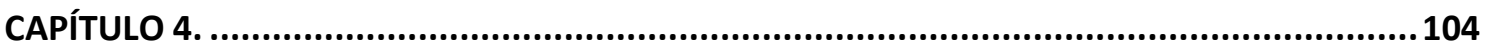

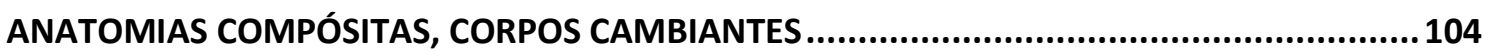

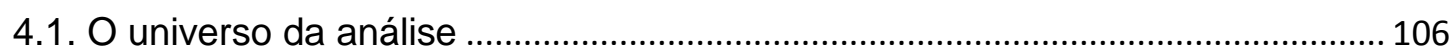

4.2. Caminhos para a análise dos campos gráficos e dos grafismos ........................ 115

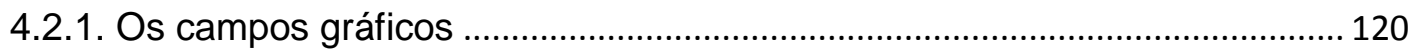

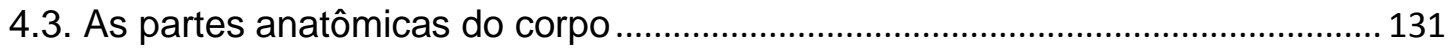

4.3.1. Imagens compósitas no mundo ameríndio .................................................... 143

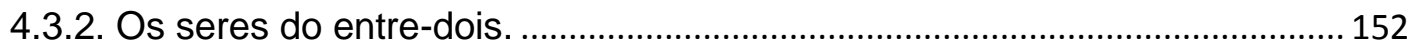

4.3.3. As anatomias compósitas e fluidas .............................................................. 158 


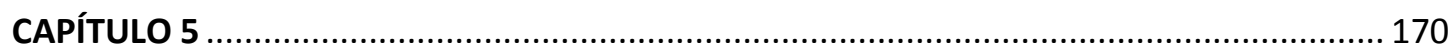

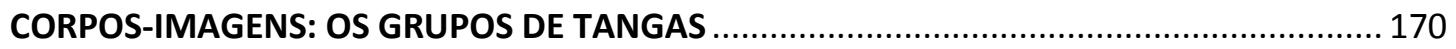

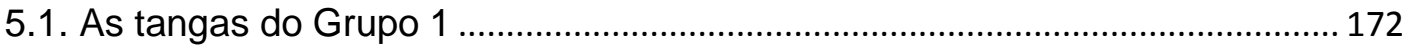

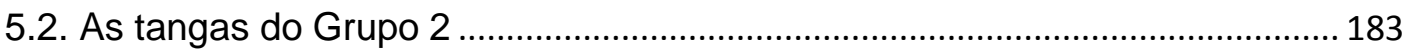

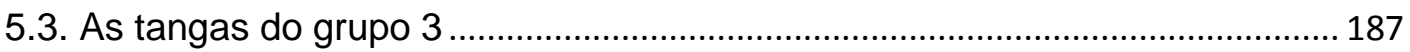

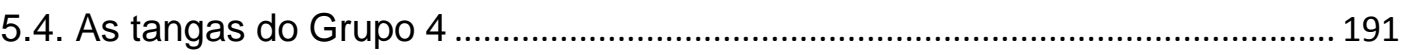

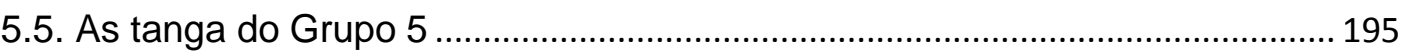

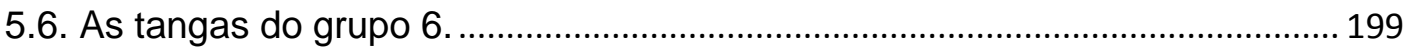

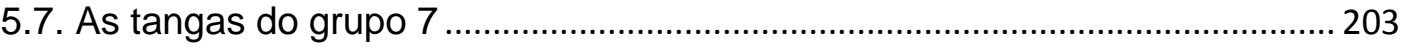

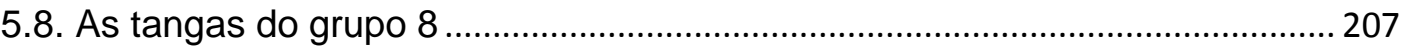

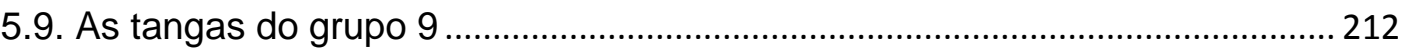

5.10. Os grupos de tangas e a variabilidade regional ............................................. 216

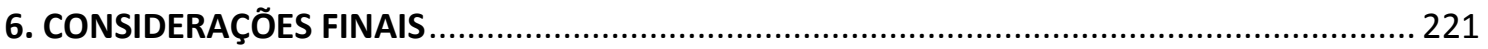

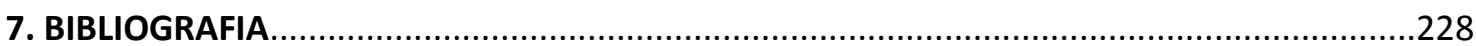

8.ANEXOS

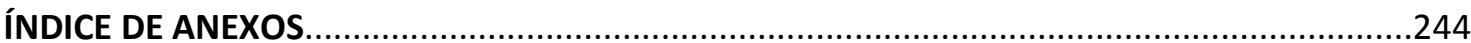




\section{Índice de Imagens e llustrações}

Figura 1- Estatueta marajoara, marcada por características antropomorfas femininas.

Fonte: Roosevelt, 1993: 264.

Figura 2- Estilo de urnas funerárias escavadas no teso Belém por Schaan, e cujos grafismos aludiriam a serpentes. Fonte: Schaan, 2007: 53

Figura 3: Urna funerária estruturada pelo desdobramento de uma figura antropozoomorfa. Nota-se que por meio da junção das figuras espelhadas outra figura é mostrada. Fonte: Barreto, 2009.

Figura 4. Tipos de tangas. a: Tanga coberta com engobo vermelho. b, c. Tangas com grafismos, cobertas com engobo claro e grafismos em tonalidade de vermelho. a, b. Coleção ICBS/MAE-USP, Museu de Arqueologia e Etnologia da USP, São Paulo . c. Museu Nacional, Rio de Janeiro.

Figura 5. Estatueta fractal A'a de Rurutu. British Museum, Londres. Fonte: Gell: 1998: 138.

Figura 6. Estatueta marajoara com triangulo pubiano em relevo recolhida por Peter Paul Hilbert no teso do Pacoval. Fonte: Barata, 1968:39.

Figura 7. Mapa sítios da fase marajoara. Modificado a partir de McEwan at al, 2001. 67 Figura 8. Esboço de perfil do teso Panellas feito por Mordini. Adaptado de Palmatary (1950).

Figura 9. Urna Pacoval Inciso e tanga escavadas por O. Derby, no teso Pacoval, dentro de uma urna simples. Fonte: Palmatary, 1950.

Figura 10. Perfil mostrando a disposição das tangas em contextos funerários no teso Guajará, Monte Carmelo (J-14). Redesenhado a partir de Meggers e Evans, 1957 ... 74

Figura 11. Orifícios de tangas apresentando marcas de desgaste.................................. 84

Figura 12. Morfologias das tangas de acordo com Prous e Lima (2011) ........................ 89

Figura 13. Comparação destacando diferença de dimensões entre as tangas. ............. 90

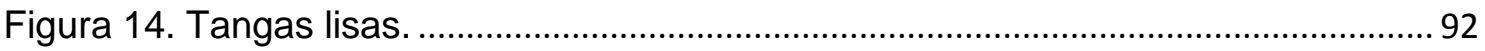

Figura 15. Tangas com grafismos com engobo de diferentes tonalidades...................... 94

Figura 16. Variação cromática das tangas com grafismos.............................................. 96

Figura 17. Jovem e criança Wajana trajando tangas masculinas. Destaque para a tanga cerimonial kupime kamisá trajada pelo jovem Fonte: Van Velthem, 1995: 188.. 98 Figura 18: Blocos de pigmentos vermelho e amarelo encontrados em urnas funerárias. Museu do Estado de Pernambuco, Recife. Fotografia: Elvira Blázquez. ....................... 100 Figura 19. "Tinteiras" ou potes para pigmento com orifícios para a suspensão. .......... 101 Figura 20- Classes de padrões de bandas formadas a partir de movimentos simétricos. Fonte: Sherpard, 1956.

Figura 21. Movimentos empregados na formação dos padrões complexos. Fonte: Gell, 1998.

Figura 22. Figura de urso em um bracelete de prata Haida composta pela união de dois perfis. Fonte: Covarrubias, 1961:43. 118 Figura 23. Desenho Kadiwéu sobre papel replicando a pintura facial que é construída por dois motivos invertidos ao longo de dois eixos de simetria. 
Figura 24. Tigela com grafismos desdobrados. Coleção ICBS-MAE, Museu de Arqueologia e Etnologia, São Paulo. Fonte: Barreto, 2009.

Figura 25. Imagem composta na tanga por meio do desdobramento a partir de um eixo horizontal.

Figura 26 - Delimitação dos campos gráficos das tangas.

Figura 27- Padrão mais frequente na banda 1 e as suas variantes. ............................. 123

Figura 28 - Padrão da banda 1 menos recorrentes.

Figura 29. Padrões da banda 2 do tipo 1. Padrões compostos por triângulos espelhados nos vértices.

Figura 30 - Variantes do padrão tipo 1. c: ICBS/MAE-USP; d, e: Museu Nacional; f:

American Museum of Natural History. Fonte: Palmatary, 1950.

Figura 31. Padrões da banda 2 do tipo 2 compostos por triângulos replicados por meio da reflexão deslizante.

Figura 32. Algumas variantes do padrão 2 em tangas . Esquerda: Museu Nacional, Rio de Janeiro. Fonte: Netto, 1885. Direita: Museu Paraense Emílio Goeldi, Belém. ........ 126 Figura 33- Padrões da banda 2 do tipo 3 compostos por motivos em forma de pentágonos com linhas duplas no interior e replicados pela reflexo deslizante, compondo um padrão do tipo allover. a1: MAE-USP/ ICBS; a2, b: Museu Nacional. 127 Figura 34- Painel gráfico estruturado em painéis verticais.

Figura 35. Campo gráfico estruturado a partir da disposição de elementos gráficos sobre um eixo virtual.

Figura 36- Estrutura do painel gráfico criada a partir da repetição de quadrantes por meio da translação.

Figura 37. - Padrões gráficos compostos por meio da simetria reflexiva, ou bilateral. Nota-se em $A$ e $B$ que o eixo de simetria é um eixo virtual, enquanto em $C$ e $D$, os eixos são sugeridos por meio dos limites dos próprios motivos gráficos.

Figura 38. Tangas com padrões gráficos onde é possível observar corpos de seres e partes de corpos, como faces.

Figura 39 - Urna Funerária com decoração excisa e figura sauromorfa modelada. University Museum. Fonte: Palmatary, 1950.

Figura 40- Figurações do "sauro" desde a sua figuração mais realista até a sua simplificação mais elementar. Fonte: Schaan, 1997.

Figura 41. Ser sauroformo figurado em urna. Nota-se a forma amendoada do seu corpo, o que parece ser uma característica básica de sua figuração. Acervo do Sistema Integrado de Museus e Memoriais/ SECULT-PA, Belém. Fotografia: Armando Queiroz.

Figura 42 - Seres figurados nas tangas que poderiam aludir a sauros. Destacam-se certas características, como corpo simetricamente duplicado, membros "abertos" e corpo losangular.

Figura 43. Motivos "cruz no medalhão" que constitui o dorso do sauro em muitos casos.

Figura 44- Detalhe destacando o motivo que alude à figura do peixe-serpentilíneo em uma urna funerária proveniente do conjunto Fortaleza. University Museum. Fonte:

Palmatary, 1950.

Figura 45- Motivos aludindo ao peixe-serpentilíneo. Museu Nacional, Rio de Janeiro. 
Figura 46. Motivos "pirâmide escalonada" que aludiriam à cabeça do ser serpentelíneo.

Figura 47- Motivo de serpente em urna do estilo pacoval inciso. Museu Etnológico de

Berlim. Fonte:

Figura 48: Temas gráficos wajana. A: Tema "caranguejo/olho de anta". B: tema gráfico onça-caramujo visto na pintura. Disponível em Severi (2013)..................................... 143

Figura 49 motivo gráfico da cegonha maguari na cestaria wajana. Severi, 2013...... 145

Figura 50 - Roda de teto (maluana) figurando a "raia enquanto anaconda". ............... 146

Figura 51. Banco Karajá coberto com grafismos recortados que sugerem a sua continuidade ao infinito. Fonte: Lagrou, 2013: 91

Figura 52- motivo tayngava asurini. Coleção Darcy Ribeiro, Museu do Índio, Rio de Janeiro. Fonte: Lagrou, 2013:95

Figura 53 - Rollout dos relevos no obelisco de Tello. Disponível em Urton, 2008. ..... 150

Figura 54 - lagartos/jacarés compondo as pequenas caras que formam os olhos das grandes faces.

Figura 55- Detalhe mostrando aplique com possíveis traços felínicos. Antiga Coleção

Barbier Mueller. Fonte: www.sothebys.com....

Figura 56- Aplique ilustrado por Netto (1885) que visto por ângulos diferentes mostra duas diferentes figuras.

Figura 57. Motivo gráfico que alude à cabeça do peixe-serpentilíneo e, que refletido, aludiria à figura do sauro duplicado.

Figura 58. Tigela com figura de peixe-serpentilíneo aludindo à figura do sauro. National Museum of the American Indian. Fonte: Palmatary, 1950.

Figura 59- Padrões da banda 2 que formam "caras" a partir de procedimentos distintos.

Figura 60- Detalhes destacando as características da cara vista no painel gráfico.

Antigo Instituto Cultural Banco Santos- MAE-USP

Figura 61 - Vaso que alude à figura de uma cara. Antiga coleção Barbier-Mueller,

Geneva. Fonte:Young-Sánchez e Schaan (2011)

Figura 62- llustração de tanga com as extremidades superiores ausentes mostrando uma cara. Museu Paraense Emílio Goeldi.

Figura 63- Figura 18- Imagem que alude a uma cara composta no painel gráfico a partir do enquadramento em um ponto específico de um padrão allover virtual. Tanga antiga coleção Barbier-Mueller, Geneva.

Figura 64- Detalhe de padrão da banda 2 com faces ocultas destacadas em amarelo. Neste caso, os triângulo refletidos aludem ao cenho e ao nariz, enquanto que o espaço hexagonal entre cada repetição dos triângulo refletidos, assim como o motivo gráfico em seu interior, aludem aos olhos.

Figura 65- Figuras que aludem a faces na composição da imagem do painel gráfico.

Tanga redesenhada a partir de Meggers e Evans, 1957.

Figura 66- Relação multi-escalar vista na sobreposição de figuras que aludem a faces em escalas diferentes. Nota-se caras menores na composição dos olhos da cara maior, no painel gráfico e, pequenas caras "virtuais" no padrão da banda 2 ............... 167

Figura 67- Hierarquização vista na maneira de estruturar as figuras.

Figura 68. Figura 1- Sítios da fase marajoara. Destacam-se em vermelho os sítios de distribuição das tangas do grupo 1. 
Figura 69- Tangas do grupo 1.

Figura 70- Layout e disposição dos padrões e motivos painel gráfico das tangas do grupo1. A. tanga grupo 1. B. Layout do painel gráfico. C. Motivo "sauro-humano" disposto no painel central. D. Disposição do motivo "pequena face-sauro" nos painéis laterais. Tanga: Coleção ICBS-MAE/USP, Museu de Arqueologia e Etnologia, São Paulo.

Figura 71. Variantes do padrão $X$, sempre compostas em três eixos, que sempre são graficamente dispostas no painel central.

Figura 72. Algumas variantes do motivo que alude a uma pequena face e, que, no grupo 1, aparece localizado sempre nos painéis laterais.

Figura 73- Rollout hipotético do padrão do painel gráfico.

Figura 74. Imagem do painel gráfico estruturada a partir de um eixo de simetria vertical.

Figura 75. Imagens caracterizadas pelo encaixe múltiplo de figuras. ............................ 182

Figura 76. Tangas com painel gráfico estruturado em painéis. ....................................... 185

Figura 77. Tangas com painéis gráficos estruturados em espaços hexagonais alternados por meio da reflexão deslizante.

Figura 78. Padrão da banda 2 aludindo a várias transformações. Tanga do acervo do Museu do Marajó. Fonte: Schaan, 2009: 375)

Figura 79. Tangas cujas imagens do painel gráfico são estruturadas por meio do desdobramento a partir de um eixo horizontal da figura que alude ao peixeserpentelíneo. Percebe-se que em todas as tangas a figura deste ser esta posicionada verticalmente, com exceção daquela ilustrada na figura $\mathrm{C}$, cuja cabeça está voltada para o eixo do painel.

Figura 80. Composição de imagem que alude a uma face por meio do desdobramento do motivo do peixe-serpentelíneo.

Figura 81. Tangas com padrões do painel gráfico constituídos por espirais e pelo motivo "cruz no medalhão".

Figura 82. Tangas em que os padrões dos painéis gráficos aludem a uma face com olhos e nariz estruturados dentro de uma área delimitada por linhas reticuladas.

Percebe-se que o cenho desta face é sugerido entre os olhos por figuras aludindo a sauros ou simplificações suas.

Figura 83. Tangas com padrão de face no painel gráfico formado pelo desdobramento do motivo que alude à cabeça do peixe-serpentelíneo..................................................... 195

Figura 84. Tangas desdobradas em dois eixos simétricos perpendiculares. ............... 197 Figura 85. Tangas estruturadas em três áreas por meio da disposição de motivos em forma de espirais losangulares em suas laterais.

Figura 86. Imagens estruturadas a partir de uma área central retangular em dois eixos perpendiculares de simetria. a, b. Museu Nacional, Rio de Janeiro. 200

Figura 87- Rollout destacando a formação de uma face por meio do desdobramento em dois eixos perpendiculares, um deles virtual, da figura do peixe-serpentilíneo. Museu Nacional, Rio de Janeiro.

Figura 88- Tangas cujo padrão alude a uma face estruturada a partir do desdobramento de figuras serpentilíneas. 203

Figura 89. Imagens compostas por motivos semelhantes, mas exibindo enquadramento de partes diferentes do padrão virtual. Percebe-se que a posição dois 
motivos acima destacados diferem nas duas tangas, com um localizado ao centro do

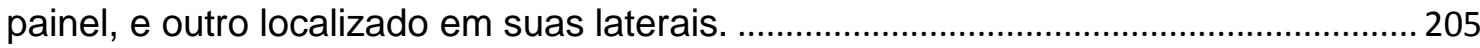

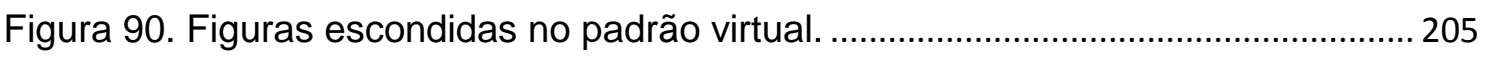

Figura 91. Imagem desdobrada em apenas um eixo de simetria. ................................. 206

Figura 92. Tangas cujas imagens dos painéis gráficos destacam um enquadramento do padrão.

Figura 93. Formas de estruturar os motivos das tangas deste grupo. As setas

vermelhas destacam a direção para a qual os membros da figura que alude ao sauro estão voltados.

Figura 94. Diferentes modos de estruturar o campo gráfico para compor uma imagem de face. 210

Figura 95. Imagens semelhantes compostas por motivos e estruturas diferentes e que escondem figuras antropomorfas.

Figura 96. Tangas com painéis gráficos compostos por padrões allover. ..................... 213

Figura 97. Tanga com padrão composto por várias figuras de faces............................ 214

Figura 98. Motivos do painel gráfico invertidos por meio da rotação............................. 215 


\section{INTRODUÇÃO}

Esta dissertação de mestrado trata da iconografia da cerâmica da fase marajoara, mais especificamente, da iconografia das tangas cerâmicas. Aqui, se propõe ampliar o conhecimento a respeito do regime de figuração expresso nas cerâmicas da fase marajoara ${ }^{1}$ tomando como base a iconografia das tangas.

Ao longo das últimas décadas alguns estudos têm se debruçado sobre a iconografia da cerâmica marajoara contribuindo de maneiras muito específicas, cada um, para a compreensão não somente das formas de representação, mas também sobre as formas de organização social (Barreto, 2009; Roosevelt, 1988, 1991; Schaan, 1997, 2004). Estes estudos, com poucas exceções, têm colocado como preocupação central a identificação de "temas" específicos, ora tentanto identificar figuras antropomorfas, ora voltando-se para figuras zoomorfas, visando associar tais temas a estruturas sócio-políticas específicas (Roosevelt, 1988, 1991; Schaan, 1997, 2004).

Para avançar a compreensão sobre as formas de figuração materializadas na iconografia da cerâmica marajoara, incorporamos a recente discussão sobre os regimes de materialidade (Santos Granero, 2013; Van Velthem, 2003) e regimes de figuração (Lagrou, 2007; Severi e Lagrou, 2013) ameríndios nesta pesquisa, além de conceitos desenvolvidos no âmbito da Antropologia da Arte, como aquele de agência dos objetos (Gell, 1998), que têm alcançado contornos na Etnologia ameríndia em virtude, sobretudo, da sua aplicabilidade à produção material na Amazônia indígena, - que, consequentemente, tem se desdobrado nos estudos das expressões artísticas da Amazônia antiga, principalmente, nas pesquisas relacionadas às iconografias cerâmicas (Barreto, op.cit; Gomes, 2001; Oliveira, 2016).

Esta abordagem tem sido empregada, na Arqueologia, em alguns estudos de coleções arqueológicas com pouca ou nenhuma informação sobre os contextos dos

\footnotetext{
${ }^{1}$ A fase marajoara é um período de ocupação da llha de Marajó, descrito primeiramente por Meggers (1954) e Meggers e Evans (1957), atrelado às culturas estabelecidas ali, entre 400 e 1300 AD., sobretudo, na sua porção leste, e que ocuparam uma área de, aproximadamente, 20 mil quilômetros quadrados (Roosevelt, 1991; Schaan, 2004). Os aterros, conhecidos como "tesos", construídos para fins funerários, rituais e de habitação (Roosevelt, op.cit.; Schaan, op.cit.), assim como as cerâmicas, elaboradas por uma gama de técnicas decorativas, tais como, incisão, excisão, pintura, modelado, etc. são as características definidoras mais emblemáticas desta fase (Barreto, 2009; Meggers e Evans, 1957; Roosevelt, op.cit.; Schaan, 2007b).
} 
quais foram retiradas (Barreto, op.cit; Gomes, op.cit; Oliveira, op.cit.), tais quais aquelas apresentadas nos capítulos 4 e 5 desta dissertação. Dadas estas lacunas, para explorar estas coleções, as pesquisas têm se voltado para os aspectos iconográficos e estilísticos dos objetos, explorando estes, principalmente, à luz do potencial explicativo das teorias e generalizações no âmbito da Etnologia e Antropologia da arte, sobretudo, daquelas relacionadas às sociedades ameríndias, permitindo, assim, organizar e analisar estes conjuntos de objetos arqueológicos.

Isto traz importantes implicações para a compreensão não somente dos aspectos iconográficos das tangas cerâmicas, objetos tão emblemáticos da fase marajoara, mas também para a reflexão a respeito de suas performances distintas. Em primeiro lugar, esta categoria de objeto pode ser compreendida a partir dos significados atribuídos à produção de adornos corporais no mundo ameríndio, sobretudo, no que diz respeito à produção e fabricação corporal. Além disto, a maneira específica de fabricar corpos e imagens, como expressa em sua iconografia, parece repercutir noções semelhantes àquelas que estruturam os regimes de figuração ameríndios, onde princípios cosmológicos relacionados à corporalidade, como por exemplo, a fabricação, a composição e a transformabilidade dos corpos, são materializados tanto nos objetos, quanto em seus grafismos.

Embora este exercício de se explorar e interpretar coleções provenientes de sociedades pretéritas à luz de conceitos e ideias de sociedades estudadas e registradas etnograficamente possa ser perigoso devido ao risco de se projetar os conhecimentos a respeito de cosmologias do presente para interpretar àquelas do passado, levando em consideração certas esferas de resistência entre a produção de imagens e identidade nas cosmovisões ameríndias, tal esforço pode ser recompensador, conforme tentaremos demonstrar nas páginas que se seguem.

De forma geral, a análise proposta nesta dissertação engloba uma investigação dos aspectos estruturais e iconográficos que caracterizam as imagens compostas nos campos gráficos das tangas, atentando, especialmente, à figuração dos corpos, definindo deste modo, alguns aspectos que caracterizam o sistema representacional marajoara. Com isto, esperamos contribuir para uma maior compreensão dos aspectos iconográficos da cerâmica marajoara, possibilitando também que os princípios estruturais que regem a fabricação das imagens possam 
ser utilizados em futuras comparações entre os aspectos iconográficos e estilísticos desta cerâmica com outras cerâmicas da Amazônia antiga.

\section{Estrutura dos capítulos}

No capítulo 1, apresentamos os estudos que se focaram na iconografia da cerâmica marajoara, problematizando como cada um, ao seu modo, relacionou os aspectos iconográficos da cerâmica ao desenvolvimento dos cacicados durante a fase marajoara.

Em um primeiro momento apresentamos como a categoria cacicado foi empregada para explicar o registro arqueológico da fase marajoara e quais os aspectos desta forma de organização social que foram identificados. Aqui, é dado destaque ao papel da iconografia e do estilo no debate centrado em torno do processo de legitimação de poder pelas hierarquias sociais. Posteriormente, discutimos como as tangas foram compreeendidas dentro das estruturas politicas dos cacicados, sendo associadas às mulheres de diferentes faixas etárias das elites dominantes, sugerindo pensá-las como objetos de composição, transformação e fabricação corporal.

No capítulo 2 apresentamos os eixos teóricos que norteiam esta pesquisa, partindo de um alinhamento entre Arqueologia, Antropologia da Arte e Etnologia. Ao adotarmos esta abordagem consideramos as esferas resistentes da relação entre imagem e identidade nas sociedades ameríndias, traz endo, deste modo, importantes implicações para a análise da iconografia das tangas.

A discussão aqui apresentada abrange, especificamente, os estudos referentes às expressões artísticas ameríndias, explorando os aspectos que lhes conferem eficácia e agentividade, e compreendendo, ao mesmo tempo, que estas materializam conceitos cosmológicos que dizem respeito à fabricação, composição e transformabilidade dos corpos.

No capítulo 3, apresentamos alguns aspectos que trazem implicações para se discutir as formas de agentividade das tangas.

$\mathrm{Na}$ primeira parte, com base nos registros de pesquisas e escavações, levantamos os seus modos de deposição em contextos funerários. Ao fim desta parte, apresentamos as análises de desgastes dos seus oríficios, que mostram que, 
apesar de ser uma categoria de objeto associada a contextos funerários, não era confeccionada especificamente para este fim, sendo usadas antes do seu descarte nestes contextos.

$\mathrm{Na}$ segunda parte, são apontados alguns apectos referentes à variabilidade das tangas que têm sido usados na formulação de hipótese sobre a sua função, como por exemplo, a variabilidade de morfologias, de tamanhos e formas de decoração. Aqui, tentamos compreender esta variabilidade por meio de um aspecto determinante na produção de roupas e adornos corporais no mundo indígena, que é a produção e paramentação dos corpos. Por fim, sugere-se que os diferentes modos de trabalhar a superfície das tangas, seja com uma pintura lisa, seja com grafismos, poderiam estar relacionados a diferentes formas de agentividade.

No capítulo 4, nos debruçamos nas características gráficas das tangas visando explorar as tecnologias que Ihes conferem encantamento. Em um primeiro momento apresentamos as coleções estudadas, bem como, os aspectos metodológicos referentes à análise dos campos gráficos e dos grafismos.

Após isto, são descritos os seus campos gráficos, bem como as características dos padrões de cada um destes campos. Posteriormente nos focamos, sobretudo, nas características específicas do regime de figuração marajoara, expressas na iconografia das tangas, destacando a forma de compor as imagens por meio da justaposição e encaixe recursivo de diversas figuras aludindo a seres específicos e partes de seus corpos, bem como o uso de princípios e recursos gráficos que conferem capacidades agentivas aos grafismos.

No capítulo 5, apresentamos nove conjuntos de tangas, organizados com base na forma de estruturar os padrões gráficos e também na recorrência de certos motivos. Concluímos este capítulo, enfatizando a ampla dispersão destes grupos pelos sítios e regiões da ilha de Marajó, o que traz implicações para se refletir sobre as hipóteses atuais que atribuem estilos cerâmicos distintivos a cacicados competitivos em que grupos de parentesco locais faziam o uso de temas iconográficos semelhantes.

Nas considerações finais retomamos os conceitos ameríndios sobre corporalidade, apresentados no capítulo 2, atentado que a forma de fabricação dos corpos, bem como certos princípios materializados na iconografia das tangas parecem mais expressar conceitos cosmológicos relacionados à transformabilidade 
destes corpos, como o constante jogo entre diferentes perspectivas, característico das cosmovisões multinaturalistas amazônicas e da ontologia da predação, do que estratégias visando à legitimação do poder de hierarquias sociais internas, conforme discutido no capítulo 1. 


\section{CAPÍTULO 1}

\section{A ICONOGRAFIA DOS CORPOS CERÂMICOS}

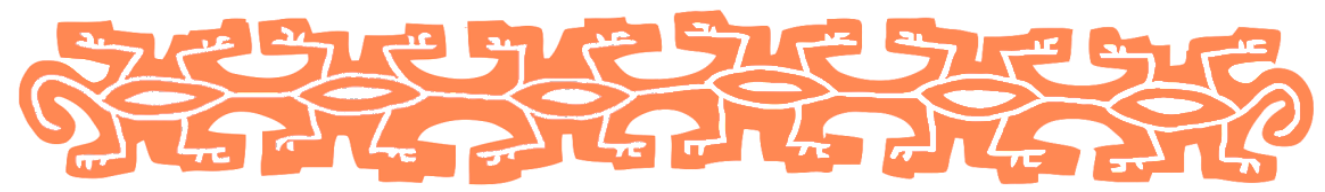

O corpo dos saurios anthropocephalos são os adornos frequentes de algumas grandes urnas funerárias. N'uma d'ellas ha um saurio, ao qual, em não pequeno gráu, descabe semelhante nome, tão inverosímil se mostra, além de outras partes, a cabeça do animal perfeitamente humana. A cauda d'este reptil, ao envez do natural, dilata-se para a extremidade e termina bruscamente, tomando assim a forma de pá. $\mathrm{Na}$ ornamentação delicadamente gravada que reveste toda a superfície da urna reconhecemse, entre caras humanas, curvas foliformes, gregas elegantes e muitos caprichosos arabescos (...).

Ladislau Netto, Investigações sobre a Archeologia Brazileira (Netto 1885: 353).

As primeiras investigações a respeito da cerâmica marajoara, ainda no século XIX, já chamavam a atenção para os seus aspectos formais, sobretudo aqueles relacionados às características das figuras. Desde aquela época a ampla diversidade de tipos de figuras e variedade de técnicas de confeccioná-las eram motivos de se especular sobre os seus prováveis significados.

Era uma ampla gama de objetos como urnas funerárias, tigelas, pratos, estatuetas, tangas, entre outros, figurando animais, humanos, seres híbridos e várias outras figuras, seja de forma modelada, pintada, por excisão ou incisão, e ainda pela combinação de várias destas técnicas, que dada a sua associação a contextos funerários, já se pensava que o seu uso estivesse associado à religião e o seu conteúdo fosse xamanístico e ritual (Ferreira Penna, 1879; Hartt, 1871; Netto, 1885).

As primeiras descrições das imagens destacavam a sua natureza intrincada. Hartt (1975), por exemplo, destacava como figuras de rostos humanos eram formadas nas tangas por meio da articulação de vários grafismos. Ladislau Netto (1885) apontava para as características de certas figuras, como por exemplo, urnas funerárias que aludiam a um corpo humano, mas com membros superiores 
caracterizados por mãos em tridígitos repousadas sobre o abdômen e com várias figuras aludindo a pequenas faces espalhadas pelo corpo, e para determinadas figuras modeladas aludindo a faces antropomorfas cujo nariz e o arco supraciliar eram compostos por uma figura sauroforme.

De fato, os estudos que adentraram no espinhoso terreno da iconografia marajoara destacam a natureza complexa deste sistema representacional, caracterizado, principalmente, por figurações de animais e humanos, representados tanto de forma mais figurativa quanto de forma mais estilizada, bem como por figuras compostas pela superposição dos corpos destes seres, de modo que a sua separação se torna impossível (Barreto, 2009; Carvalho, 1976; Roosevelt, 1991; Schaan, 1996,1997).

As figuras antropomorfas podem ser vistas em urnas funerárias, estatuetas e apêndices, com faces caracterizadas por sobrancelhas e nariz unidos em $\mathrm{Y}$ ou $\mathrm{T}$, pintura facial, adorno labial, adorno auricular, contorno dos olhos por figuras de escorpiões. Já as figurações de animais mostram lagartos e jacarés, escorpiões, corujas, serpentes, urubus reis, entre outros. As representações zoomorfas são vistas em vários tipos de objetos, como urnas funerárias, pratos, vasos, etc, mas tais representações nem sempre obedecem às características físicas do animal representado, de modo que podem ser completamente estilizadas, apresentando diminuição de membros e dedos, ou com partes corporais duplicadas, mudanças nas proporções corporais e formas dos membros, ou ainda como figuras compostas de partes de animais e humanos, etc. (Schaan, 1996,1997).

As figuras que reúnem características híbridas de animais e humanos são proeminentes em estatuetas, vasos, tigelas e, principalmente nas urnas funerárias, sobretudo, naquelas que mesclam traços ornitomorfos e características humanas, como por exemplo, faces compostas por grandes olhos redondos, com pálpebras semi-cerradas e salientes, nariz e boca em relevo, emolduradas por faixas em $T$, aludindo provavelmente à cara de uma coruja, elementos que aludem às suas presas, além de atributos como orelhas com lóbulos, provavelmente humanos, com botoques e elementos que sugerem adornos de penas (Barreto, 2009; Roosevelt, 1991; Schaan, 1996,1997).

Apesar desta diversidade de seres figurados poucos estudos se debruçaram sobre a iconografia da cerâmica marajoara pensando em seu papel na configuração 
dos corpos sobre os quais estão dispostos ou pensando em sua relação na estruturação das imagens. No geral, os esforços são para identificar certos tipos de "temas" classificados como antropomorfos, zoomorfos e, em alguns casos, geométricos, como visto no estudo de Roosevelt (1991).

Como resultado do esforço de identificar ou isolar certos "temas" as imagens acabavam por vezes "desmembradas" ou fragmentadas. Assim, por exemplo, se a morfologia de uma urna funerária aludisse à forma humana, então a imagem era considerada como uma figura humana, mesmo havendo figuras de animais no conjunto. Ou seja, a classificação do "tema" era feita com base na figura que mais se destacava no conjunto. O objetivo por trás disto era quantificar a frequência destes "temas" (Roosevelt, op.cit.).

Em outros casos, por exemplo, a imagem só era analisada em parte, por que o interesse estava voltado para certas figuras ou padrões, como por exemplo, figuras serpentilíneas (Schaan, 2004).

Por trás deste desmembramento da imagem havia um esforço em correlacionar certos tipos de figuras a um incremento de poder de certos grupos sociais que se desenvolveram nas estruturas dos cacicados.

\subsection{Imagens da cultura e da natureza}

Desde Meggers e Evans (1957) se tem pensado a arte para se discutir complexidade social nas terras baixas da América do Sul. A presença de urnas funerárias, tigelas, pratos, vasos e estatuetas decoradas e objetos líticos, como os muiraquitãs e os ídolos de pedra, devido à sua elaboração técnica e estética, fecundaram o debate sobre a presença e ausência das sociedades complexas na Amazônia. Deste modo, pelo menos inicialmente, a arte foi tratada pela Arqueologia como um marcador de complexidade social (Barreto, 2009).

Os principais estudos sobre a cerâmica marajoara, especificamente, se inserem dentro de um debate a respeito de organizações sócio-políticas do tipo cacicado. Desde as pesquisas de Meggers e Evans (op.cit.) que esta cerâmica, seja por meio de suas técnicas de decoração, seja por meio da sua iconografia, tem sido, de uma forma ou de outra, relacionada a formas de organização social. 
O primeiro estudo sistemático a respeito desta cerâmica destacava a sua diversidade de formas e técnicas decorativas e dele surgiu a primeira tipologia cerâmica para a fase marajoara (Evans e Meggers, op.cit.). O cerne da pesquisa de Evans e Meggers, entretanto, estava menos focado na organização social e no simbolismo da decoração cerâmica, e mais na questão adaptativa. Meggers e Evans propuseram que as características vistas nas cerâmicas, elaboradas com sofisticadas técnicas decorativas, como excisão, incisão, modelado e policromia, e associadas a aterros artificiais, se assemelhariam mais a um padrão arqueológico do tipo circum-caribenho do que de floresta tropical, o que parecia uma anomalia.

Diante disto, os autores desenvolveram uma tipologia cerâmica baseada na frequência de técnicas decorativas que foi utilizada posteriormente para explicar a sequência de desenvolvimento da fase marajoara. Tal tipologia era pautada em tipos cerâmicos resultantes da combinação de certas técnicas decorativas em dadas morfologias. Alguns tipos, implicitamente considerados mais antigos, eram decorados com combinações de técnicas consideradas como mais complexas, já que consumiam mais tempo em sua elaboração (Barreto, 2010; Meggers e Evans, 1957: 324-424;).

A seriação com fragmentos de vários sítios mostrou que os tipos cerâmicos mais complexos eram mais abundantes em sítios mais antigos, diminuindo em popularidade com o passar do tempo, enquanto os tipos que requereriam menos tempo para sua execução aumentavam em popularidade. Deste modo, propuseram que a fase marajoara seria o correlato de uma população exógena que inicialmente apresentava um padrão de organização política do tipo cacicado, que em contato com as limitações do ambiente, teria entrado em um rápido processo de decadência cultural, levando a um padrão de floresta tropical.

Desde então, modelos mostrando um cenário oposto a este, e nos quais a iconografia cerâmica possui papel de destaque, foram elaborados para explicar o padrão visto no registro arqueológico da fase marajoara. Tais modelos destacam o surgimento de cacicados a partir do desenvolvimento local e não como um fator de migrações e influências externas. Neste sentido, explica-se o desenvolvimento econômico como produto do trabalho humano, seja por meio do cultivo intensivo de grãos, seja por meio da construção de barragens que viabilizassem a exploração dos recursos aquáticos. 
Aqui, de certo modo, a iconografia é vista como o reflexo de desenvolvimento social, seja ao destacar o aumento de figuras humanas à medida que a sociedade vai se desenvolvendo devido às práticas agrícolas que trazem consigo o aumento do controle da mão de obra humana juntamente com justificativas ideológicas (Roosevelt, 1987, 1988, 1991, 1992), seja relacionando figuras de serpentes aos recursos ribeirinhos e à importância destes no desenvolvimento dos cacicados, assim como o uso de um estilo que abrange estas figuras em justificativas ideológicas para o acesso diferenciado aos recursos (Schaan, 2004, 2007a).

\subsubsection{Imagem e complexidade social}

As discussões sobre a iconografia da cerâmica marajoara subjazem dentro de um debate mais amplo que diz respeito ao desenvolvimento dos cacicados na Amazônia. Na Amazônia, o debate sobre o desenvolvimento dos cacicados se iniciou nos anos 80 com as pesquisas de Roosevelt (op.cit.), mas já era um tema bem consolidado em outras regiões, como Andes e Mesoamerica, de onde modelos para a formação de estados foram "importados".

Os cacicados correspondiam a um dos estágios evolutivos vistos por Steward $(1946-1950)^{2}$ e estavam correlacionados às culturas do tipo circum-caribenhas. Segundo Fausto (2005a), quando Colombo aportou às Antilhas em 1492, ele a encontrou densamente povoada por uma população falante de uma língua Arawak, conhecida como Taino. O chefe desta população era denominado kasik, termo a partir do qual os espanhóis cunharam o termo cacicazgo para denominar a região controlada por esse chefe.

\footnotetext{
${ }^{2}$ É importante destacar que Julian Steward organizou a coletânea Handbook of South American Indians onde foram definidas categorias geográficas e evolutivas que visavam organizar as sociedades indígenas da América do Sul com base na integração destas nas estruturas socioculturais. Editada entre 1946 e 1950, em seis volumes, a obra agrupava os povos indígenas da região em quatro áreas culturais hierarquizadas em função da complexidade: bandos marginais, tribos de floresta tropical, povos do Circum-Caribe e civilizações andinas. Assim, os "bandos ou povos marginais" englobavam as populações caçadoras-coletoras nômades, caracterizadas, sobretudo, pela falta de cultivo e pela simplicidade de sua tecnologia; já os povos de "floresta tropical", de acordo com este modelo, se caracterizariam pela horticultura e pela pesca, por aldeias permanentes e pela falta de instituições políticas, com organização estabelecida por meio do parentesco, ou seja, sem poder centralizado; os povos do Circum-Caribe (posteriormente denominada cacicado), por seu turno, foram caracterizados com base em seu insipiente sistema de centralização política e religiosa, bem como em seu sistema de classes, caracterizado, principalmente, pela existência de hierarquias sociais e pela especialização técnica dos indíviduos. Por fim, os povos andinos foram distinguidos, sobretudo, com base em seu complexo aparelho estatal, estratificação social, especialização e desenvolvimento de técnicas como a metalurgia, densidade populacional e intensificação da produção agrícola e pastoril.
} 
Na literatura, o termo foi utilizado primeiramente por Karlevo Oberg em 1955, baseado nas áreas culturais definidas anteriormente por Steward (1946, 1947, 1948, 1949) no Handbook of South American Indians. Mas foi com Elman Service em 1962 que o termo passou a ser amplamente discutido, por meio da criação das tipologias dos seguintes estágios evolutivos: bando, tribo, cacicado e Estado (Arcuri, 2007; Carneiro, 2007; Fausto, 2005; Gomes, 2002).

O termo "cacicado" foi amplamente empregado ao redor do mundo para diferentes sociedades, de modo a torná-lo genérico. Segundo Fausto (2005:40), cacicado tornou-se uma categoria aberta, designando sociedades as mais diversas, cuja única característica em comum é estar no "meio de" ou a "caminho de".

Os cacicados poderiam ser reconhecidos nos vestígios arqueológicos por meio de traços como arquitetura monumental, centros cerimoniais, e estruturas funerárias, pois indicariam diferenças sociais, assim como por meio das diferenças na hierarquia entre os assentamentos (Carneiro, 1981). Fausto (op.cit) aponta, todavia, que devido à utilização generalizada do termo, as evidências no registro arqueológico são mais amplas, como por exemplo:

(...) diferenças entre assentamentos que apontem para a existência de um
centro regional; obras públicas que demonstrem mobilização de trabalho
coletivo; alterações na topografia que indiquem técnicas agrícolas
envolvendo trabalho intensivo; diferenças no tamanho das habitações, nos
modos de sepultamento, na localização de bens de prestígio ou nas
estruturas do sítio que apontem para estratificação social; artesanato
refinado que expresse especialização ocupacional; grande quantidade de
produtos exóticos que evidencie uma rede comercial desenvolvida e
integração supra local (Fausto, 2005: 40-41).

$\mathrm{Na}$ Arqueologia de Marajó, sobretudo, na discussão sobre os cacicados, muitos dos traços supramencionados foram reconhecidos no registro arqueológico (Roosevelt, op.cit.; Schaan, op.cit.), como por exemplo:

- Construções monumentais: construção de montículos de terra por meio do controle da mão de obra (Roosevelt, op.cit.; Schaan, op.cit.).

- Diferenças entre assentamentos e centro cerimoniais: Schaan (2004a, 2004b) reconheceu diferenças de altura, área e cultura material que se relacionariam a uma hierarquia entre os 34 tesos do conjunto Os Camutins. Em 7 deles, havia uma maior proporção de fragmentos decorados, e além disto, estes tesos eram os maiores do grupo, 
indicando que eram usados para festas, rituais e residência da elite, enquanto que os outros seriam usados pela maioria da população.

- Obras públicas: Construção de reservatórios para reter peixes e garantir suprimento de água durante a seca (Schaan, 2004).

- Participação em redes para a aquisição de bens de prestígio: Acesso das elites regionais a bens de prestígio, como por exemplo, contas e pingentes de nefrita, machados de pedra, trazidos de regiões distantes (Schaan, 2004:144).

- Especialização no artesanato: Cerâmica cerimonial produzida por uma elite (Roosevelt, 1991:370) e caracterizada como um item de prestígio produzido apenas por alguns membros selecionados que tiveram acesso a certos conhecimentos e que poderiam gastar tempo indefinido na realização dessa atividade (Schaan, 2004:353). Esta especialização poderia ser vista em características como: superfícies com melhor alisamento e polimento; modelagens figurativas mais apuradas; por decoração incisa-excisa aplicada nas paredes externas de forma mais fina e complexa, combinada com pintura vermelha e branca; pintura policrômica figurativa mais apurada; formas com contornos mais complexos, carenadas, e por vezes formando silhuetas excêntricas ou efígies; as bordas são mais grossas, angulares e complexas, e são freqüentemente decoradas com adornos figurando humanos e animais; as bases são mais complexas, incluindo bases em pedestal (Barreto, 2009: 130-131; Roosevelt, 1991:370).

Outro aspecto subjacente aos cacicados, e que se imbrica em um debate muito mais amplo, diz respeito ao papel da arte nestas estruturas políticas. Muito foi debatido a respeito dos usos da arte o e do estilo pelas elites nestas sociedades. No geral, os autores mostram que em cacicados complexos, ou em sociedades que passam por mudanças sócio-políticas de forma a aumentar a hierarquia entre indivíduos, quase sempre aqueles que integram a elite dominante fazem amplo uso da cultura material e das imagens para vinculá-la a forças ou entes sobrenaturais como parte de uma ideologia que afirma a sua divindade e que as suas regras são 
parte de uma ordem natural do universo (Earle, 1990, 1991; Gillespie,1993; Neitzel, 1995; Pozorski e Pozorski, 2011).

Todo este debate estava centrado na eficácia do estilo e da arte neste processo. As publicações destacavam que uma grande variedade de mensagens pode ser transmitida pelos objetos. Deste modo, o estilo dos objetos informaria quanto à associação de certo indivíduos tanto na sociedade como um todo, como em determinados níveis na hierarquia social; estas mensagens também identificam como os líderes comunicam e reafirmam seu poder político e prestígio, bem como a força das suas relações com os deuses, ou seja, a arte seria usada nos cacicados para distinguir a elite dominante e legitimá-la como um grupo à parte e destacar a sua ligação direta com as forças sobrenaturais (Earle, op.cit; Neitzel, op.cit).

Esta abordagem a respeito do estilo dentro dos cacicados teve um papel fundamental nas discussões sobre a iconografia da cerâmica marajoara.

\subsubsection{A imagem do humano}

Roosevelt (1987, 1988, 1991, 1992, 1993) sugeriu um modelo para explicar o desenvolvimento social e cultural das sociedades amazônicas pré-coloniais em que um dos principais aspectos sugeria o aumento de figuras antropomorfas nas sociedades do baixo Amazonas (especialmente no Marajó e Santarém) à medida que as sociedades se tornavam cada vez mais complexas, com uma economia cada vez mais voltada para a agricultura.

A autora, ao mesmo tempo em que concorda com a interpretação de Meggers e Evans (op.cit.) a respeito de uma cultura com um nível de desenvolvimento do tipo circum-caribenho ou sub-andino, e que autora se refere como cacicado, questiona, sobretudo, a origem da cultura marajoara e a sua duração, bem como a ideia de um declínio em função das adversidades do ambiente. O cenário que propõe para Marajó, no entanto, é o de grandes cacicados caracterizados por organização social hierárquica, manufatura especializada da cerâmica, culto de ancestrais, cultivo intensivo de grãos e exploração da fauna aquática e por assentamentos com grandes contingentes populacionais (Roosevelt, 1987, 1991, 1992,1993).

Para se ter uma ideia da magnitude do cenário imaginado, só no teso llha dos Bichos, a autora teria identificado cerca de 25 casas, e naquela escavada, foram 
encontrados grandes fogões de cerâmica que sugeririam terem sido mantidos por um longo período. Segundo as suas estimativas, cada uma destas 25 casas era habitada por uma média de 40 pessoas, o que somado resultaria em uma população total de cerca de mil habitantes para o teso (Roosevelt, 1991: 404). Entretanto, a população total da ilha poderia ter sido ainda maior, considerando apenas os sítios conhecidos, estimando entre $100 \mathrm{mil}$ e $200 \mathrm{mil}$ pessoas, mas que poderia ter chegado a um milhão. Com isto, a densidade populacional teria sido bastante substancial, com cerca de 5 a 10 pessoas por quilômetro quadrado, considerando-se que o domínio marajoara abrange 20 mil quilômetros quadrados (Roosevelt, 1991: 38).

No entanto, apesar dos seus esforços para demonstrar que o cultivo intensivo do milho foi o principal alimento na ilha, as suas escavações não mostraram evidências diretas do seu cultivo em larga escala, mas sugeriram o cultivo intensivo de outros grãos. Os ricos solos aluviais, sobretudo na porção centro-oriental da ilha, de acordo com a autora, seriam mais adequados para o cultivo de grãos, o que somado às ricas fontes permanentes de água forneceria uma ampla oferta de recursos como peixes e frutas, tanto é que as análises osteológicas e de vestígios de alimentos indicaram que a dieta era baseada no cultivo de sementes, coleta de plantas e na pesca sazonal intensiva (Roosevelt, 1991:405). A principal fonte de proteína animal seria o peixe, mas a base alimentar, de acordo com as patologias dentárias, seria os cereais. Segundo a autora, análises isotópicas em ossos demonstram o consumo de milho em um nível de apenas de 20 a 30\%, mas outras sementes e cereais nativos poderiam ter complementado a dieta (Roosevelt, 1991:76). Mais tarde ela propõe o arroz selvagem como o cereal mais utilizado pelas sociedades marajoaras.

Esta mudança no modo de vida, segundo a autora, caracterizada pela expansão populacional e desenvolvimento sócio-político, e que seguiu um processo de dependência de cultivo de grãos, como por exemplo, o milho, em detrimento de amidos de raízes tropicais e da fauna, seria correlata do desenvolvimento econômico durante o período pré-histórico tardio na América do Norte e em muitas partes do Velho Mundo ao longo do Neolítico (Roosevelt, 1991:76).

A partir disto, Roosevelt (op.cit.) sugere que a introdução de uma economia agrícola levou a grandes mudanças e também teria se refletido na arte, mais 
especificamente em certos padrões gráficos. Segundo a autora, as figuras animais, predominantes na arte pré-colonial das sociedades precoces amazônicas e na arte dos povos ameríndios amazônicos do presente, podem ser interpretadas como parte de ritos de iniciação e de rituais de cura e de caça para influenciar os espíritos animais que controlam a fartura humana e animal, já nas sociedades pré-coloniais tardias, sociedades bem complexas e onde os objetivos de subsistência e conceptualização do poder seriam diferentes dos vistos naquelas, as figuras humanas são proeminentes, conforme visto na cerâmica marajoara (Roosevelt, 1991:89).

Esta imagem humana marajoara, de acordo com autora, é predominantemente feminina e demonstraria o crescimento da importância das mulheres. Diante do crescimento econômico e demográfico, as mulheres adquiriram status devido aos seus papeis na plantação, coleta e processamento. Nisto, a profusão de certos artefatos com representação de figuras femininas, como as estatuetas cerâmicas e urnas funerárias, estaria relacionada ao protagonismo da mulher naquela sociedade, uma vez que, com a agricultura, aumentavam as atividades de roça, e de processamento e preparação de alimentos (atividades femininas), aumentando assim a sua participação na economia, em contraposição a uma sociedade de economia mais caçadora-coletora, onde o papel do homem era mais preponderante (Roosevelt, op.cit.).

Esta relação entre imagem antropomorfa e organização social foi mais desenvolvida em um estudo que correlaciona, particularmente, a iconografia das estatuetas cerâmicas de Marajó e Santarém ao papel feminino no desenvolvimento dos cacicados

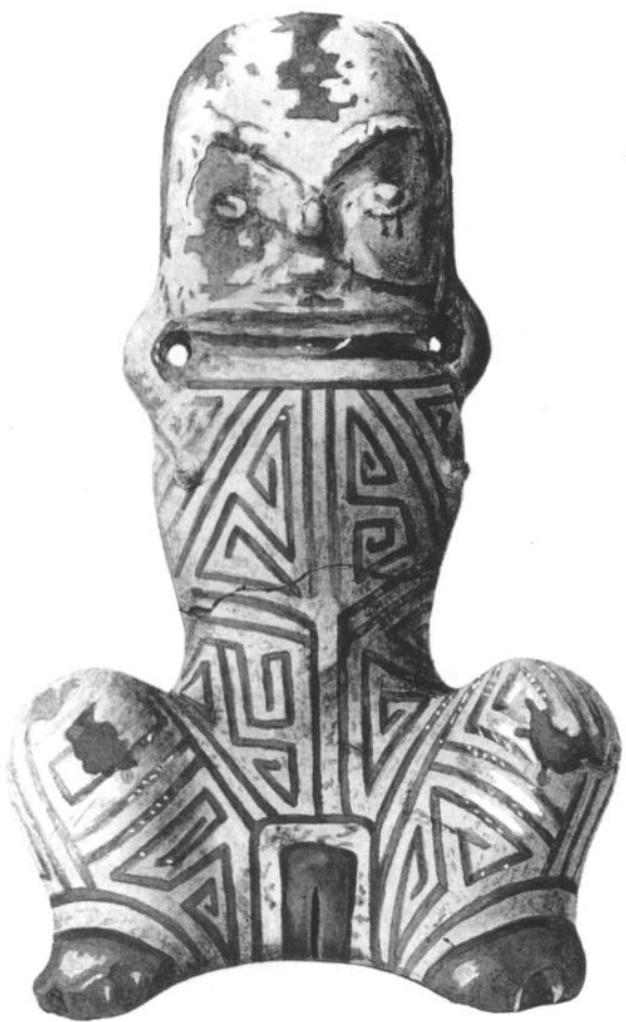

Figura 1- Estatueta marajoara, marcada por características antropomorfas femininas. Fonte: Roosevelt, 1993: 264. na Amazônia (Roosevelt, 1988). Esta iconografia antropomorfa é caracterizada principalmente pela presença de atributos 
femininos, os quais podem ser brevemente descritos assim: a mulher é gorda, está nua ou semi-nua e tem o corpo altamente ornamentado; frequentemente está grávida ou está amamentando; está em posições eróticas, com as mãos sobre os seios, quadris, abdômen, coxas ou genitália; a genitália frequentemente é destacada e exibida; certas características sexuais secundárias como coxas e nádegas são aumentadas; muitos exemplares são feitos em forma de pênis ereto; são feitas de argila (Roosevelt, 1988).

Como se pode notar, a autora prioriza em sua análise as características modeladas das figuras, e só faz referência aos grafismos para destacar a pintura corporal das estatuetas, de modo que certos atributos da composição corporal, também definidos pelos grafismos, como por exemplo, olhos, bocas e outros, são ignorados.

Do mesmo modo, ao se voltar para as características das urnas funerárias, a sua preocupação reside em demonstrar que se trata de figuras humanas, especificamente femininas. Deste modo, as urnas do estilo Pacoval, por exemplo, foram descritas como "figuras antropomorfas femininas", em posição sentada, com triângulo pubiano com pontos salpicados que aludem a pelos, com os olhos delineados por escorpiões e serpente modeladas como braços (Roosevelt, 1991: 81 82). A presença de urnas antropomorfas em contextos funerários, para a autora, estaria relacionada a cultos mortuários de veneração às elites ancestrais, já que se assemelhariam às múmias e seus acessórios que eram veneradas como objetos de cultos nos cacicados etno-históricos (Roosevelt, 1991: 81; 1992: 80). No caso das urnas Pacoval, notadamente femininas, os seus olhos em forma de escorpiões e braços serpentelíneos poderiam ser vistos como símbolos de poder xamanísticos e denotariam a proeminência das mulheres em papel de xamãs (Roosevelt, 1991:82).

De acordo com a autora (Roosevelt, 1987: 160; 1991: 76-97, 1992: 80), as características desta iconografia na qual as figuras humanas predominam em relação às figuras de animais podem ser sintetizadas do seguinte modo:

- As imagens humanas, geralmente são as principais e maiores, enquanto que as imagens de animais se resumem a detalhes ou pequenas efígies, ou seja, são reduzidas a acessórios decorativos das figuras humanas. 
- Em caso de imagens mostrando a interação entre humanos e animais, como ocorre em urnas, vasos e estatuetas, as figuras humanas compõem a imagem central ou maior, enquanto as figuras animais ocorrem somente como pequenos detalhes ou apliques e apêndices, como se vê nas urnas do estilo Pacoval, por exemplo.

Neste sentido, o modelo de Roosevelt (op.cit.) assumia, mesmo que de maneira não muito explícita, o pressuposto de que o estilo pode ser utilizado na legitimação de ideologias. A autora assume que, em Marajó, a importância da imagem humana derivou do emprego da arte para sustentação genealógicas das elites ao poder e ao prestígio (Roosevelt, 1991: 80). Neste sentido, a arte seria um fator legitimador de direitos ancestrais. Assim, para controlar a mão-de-obra necessária ao cultivo da terra, teria sido preciso às novas elites fazer o uso de imagens humanas relacionadas aos ancestrais.

Segundo a autora (Roosevelt, 1988), certas evidências corroborariam a sua hipótese. A intensificação de figuras humanas teria sido apenas um dos aspectos subjacentes a uma transformação mais ampla e caracterizada por uma mudança na subsistência com o cultivo intensivo de cereais, construção de sistemas de terraplanagem para a agricultura, controle da água, transporte e defesa, rápida expansão populacional, surgimento de assentamentos em escala urbana e, por fim, investimento intensivo na produção de objetos de arte (Roosevelt, 1988: 3-4), ou seja, todas as transformações identificadas por ela só poderiam ter ocorrido se houvesse algum tipo de controle sobre o trabalho humano que fosse justificado por meio da ideologia, e no qual a arte tinha um papel crítico.

No entanto, nunca foi documentado arquelogicamente que uma mudança para uma economia mais voltada para a agricultura teria levado ao incremento de figuras humanas em detrimento de figuras de animais na iconografia da cerâmica marajoara. Este modelo tem sido criticado tanto por arqueólogos (Barreto, 2009, Carneiro, 2008; Schaan, 2004) quanto por antropólogos. Viveiros de Castro (2002: 340-341) discutindo o papel da Arqueologia na derrocada do modelo padrão de Steward (op.cit.) vê uma notável contradição entre o cenário proposto por Roosevelt e o cenário visto pelos antropólogos. Para o autor, as características das sociedades indígenas contemporâneas, como por exemplo, a enorme importância ideológica 
conferida à caça, mesmo naquelas mais voltadas para a horticultura, a concepção das relações com a natureza que privilegia as interações sociais e simbólicas com o mundo animal, e onde o xamanismo se destaca, além da generalização de uma ideologia da predação ontológica como regime de constituição das identidades coletivas, inviabilizariam regimes ideológicos associados à agricultura e à centralização política na região (Viveiros de Castro, 2002: 342-343).

De fato, diferentemente das iconografias das sociedades andinas que trazem referências às plantas que ocupam um lugar central nas cosmovisões, como por exemplo, na cerâmica moche, que mostra seres de cujos corpos saem mandioca e milho (Golte, 2009: 228), ou mesmo nas estelas de pedra de Chavín de Huantar, cujas figuras revelam a presença de mandioca, abóbora e outras plantas (Urton, 2008), as iconografias das cerâmicas amazônicas são marcadas pela presença de figuras híbridas de animais e de humanos, especificamente na iconografia da cerâmica marajoara, os estudos iconográficos (Barreto, 2009; Schaan, 1996, 1997) não demonstram figurações de plantas que indicassem a importância das relações com o mundo vegetal.

\subsubsection{O corpo coberto de serpentes}

Posteriormente Schaan (2003, 2004, 2009) avançou algumas hipóteses de Roosevelt (op.cit.) em sua pesquisa realizada no conjunto de tesos Os Camutins, um grupo de 34 montes artificiais localizados ao longo do rio Camutins. Esta autora, ao modo de Roosesevelt, concorda com o modelo "cacicado" para explicar as características vistas nos vestígios arqueológicos, mas, diferentemente daquela, propõe que uma economia muito mais baseada na exploração dos recursos ribeirinhos e silvestres teria impulsionado o desenvolvimento da complexidade social na ilha durante a fase marajoara.

O seu modelo propõe que grupos familiares teriam construído barragens e lagos articificais junto às áreas de concentração dos recursos aquáticos com o fim de otimizar a captura de peixes ao fim da estação das chuvas, o que teria incrementado a oferta de recursos e gerado excedentes, propulsionando a criação de mecanismos para o seu controle, levando, por seu turno, à estratificação social. Diante disto, os grupos familiares teriam aumentado o seu poder, por meio do 
controle ao acesso dos recursos, o que teria sido justificado por meio de um sistema ritualístico-religioso de legitimação estruturado no parentesco com os ancestrais míticos (Schaan, 2004, 2007, 2009).

Com o surgimento dos cacicados, ou sociedades regionais, segundo a autora (Schaan, 2007:55), na Amazônia, a arte teria sofrido drásticas mudanças como consequência de processos econômicos e políticos. Com o desenvolvimento destas sociedades com estruturas políticas mais estáveis a arte teria assumido um papel crítico na reprodução social, e poderia ter sido usada pelas novas elites como
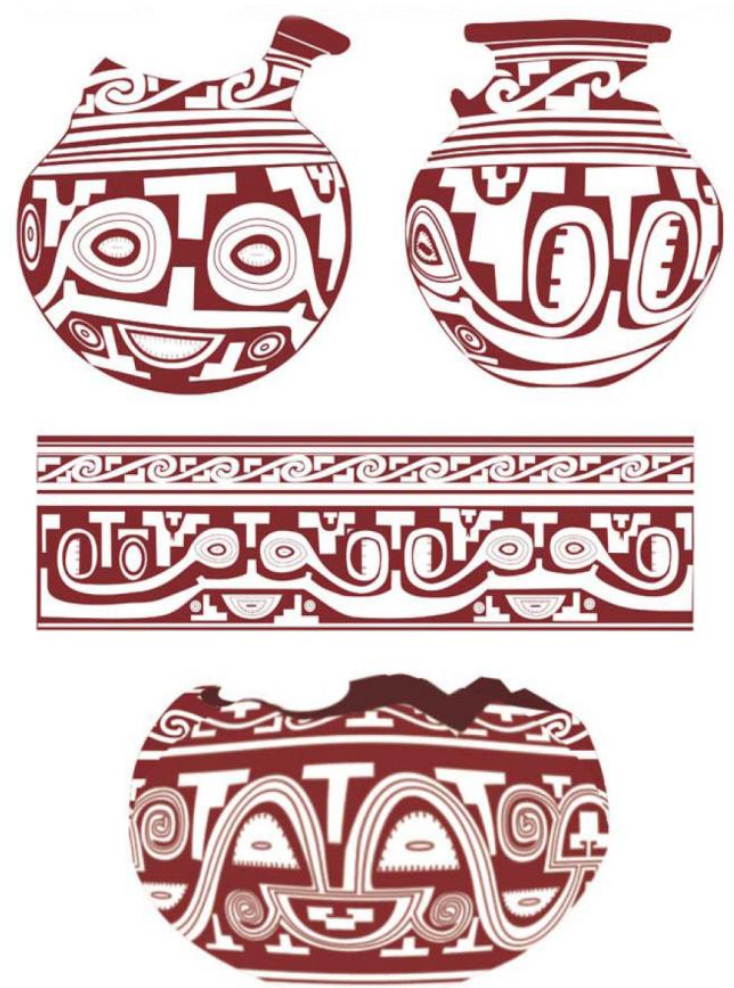

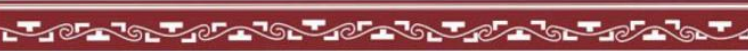
(2)

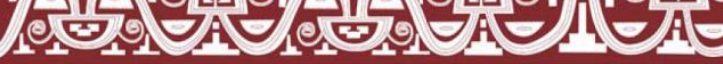

Figura 2- Estilo de urnas funerárias escavadas no teso Belém por Schaan, e cujos grafismos aludiriam a serpentes. Fonte: Schaan, 2007: 53

maneira de legitimar o seu poder, como veículo privilegiado para a expansão e consolidação das novas ideias.

Isto seria particularmente notável na iconografia das urnas funerárias marajoara. As urnas escavadas no teso Camutins e no teso Belém, por exemplo, mostraram diferenças quanto à padronização da forma e iconografia. No teso Camutins, haveria uma maior variabilidade em relação à forma, técnica de decoração e iconografia, enquanto no teso Belém haveria uma maior padronização caracterizada por urnas globulares decoradas com padrões vermelhos ou vermelhos e pretos pintados sobre 0 engobo branco que aludiriam a serpentes. A homogeneidade na decoração, forma e iconografia das urnas do teso Belém indicaria uma uniformidade na identidade social, sugerindo que o casamento no local era restrito a pessoas da mesma linhagem. No caso das urnas do Monte Camuntins, a maior variabilidade poderia indicar alianças matrimoniais entre cônjuges de diferentes grupos de parentesco das elites (Schaan, op.cit.). 
Tais variações do estilo e iconografia destas urnas se relacionariam a uma variedade de elementos emblemáticos de certos grupos sociais, como por exemplo, clãs ou linhagens. Por esta razão, os sepultamentos dos indivíduos nelas seria uma prática reservada aos membros da elite, isto é, aos indivíduos pertencentes a grupos de descendência ou a linhagens com maior prestígio, e esta é a razão pela qual os enterramentos ocorreriam em grupos, formando densas estruturas funerárias. O sepultamento secundário de indivíduos nestas áreas sagradas destacaria o seu pertencimento a um grupo ancestral, demonstrando e reafirmando os laços genealógicos em cerimônias funerárias, o que promoveria maior status ao morto e à nova geração (Schaan, 2004).

Segundo Shaan (op.cit.), embora estas urnas apresentem estilos que, aparentemente, eram usados ativamente por entidades sociais, em sua iconografia há uma proeminênicia de serpentes e seres aquáticos em relação a outros seres. Tais serpentes aparecem sempre, seja de maneira mais realista, seja de maneira mais estilizada (Schaan, 2004: 360), como por exemplo, na forma de certos padrões repetitivos que foram interpretados como serpentes ou padrões que aludem à pele da serpente, e que podem ser vistos em uma gama de objetos, tais como as tangas (Schaan, 2001). Estes padrões são compostos por uma série de elementos como triângulos, escalonados, volutas, etc, e seriam vistos também em representações mais "naturalistas" de serpentes na iconografia marajoara.

Estes padrões de banda lembrariam aos membros do grupo sobre conceitos cosmológicos importantes sobre o mito da cobra, que provavelmente era usado para justificar a hierarquia social e acesso diferenciado aos recursos (Schaan, 2004:360361). Diante disto, a proeminência da figura da serpente na iconografia marajoara se justificaria devido ao papel que os recursos aquáticos teriam desempenhando no desenvolvimento dos cacicados marajoara como a principal fonte de subsistência (Schaan, 2007).

Esta discussão impactou diretamente a forma como a arte, o estilo, e a iconografia foram tratados nos estudos a respeito das sociedades pré-coloniais da Amazônia, principalmente, naquelas que mostravam evidências de complexidade social, como aquelas da fase marajoara e Santarém. Mais especificamente em relação à cerâmica marajoara, como vimos, o estilo e iconografia foram entendidos dentro de um contexto em que a proeminência de certas figuras estava relacionada 
a formas específicas de legitimação de poder pela elite. A arte, portanto, foi correlacionada a mudanças nas estruturas sociais, a um processo de transformação de uma sociedade igualitária em uma sociedade hierárquica.

\subsection{A imagem do corpo e a composição do corpo}

Recentemente uma mudança de enfoque sobre as artes ameríndias subjaz dentro de uma discussão mais ampla e que chama a atenção para a possibilidade de "olhar" mais abertamente para as sociedades pretéritas. Hoje, por exemplo, se admite que na Amazônia antiga houvesse uma maior diversidade social antes da conquista, com sociedades mais ou menos complexas, e que, além disto, correlacionar determinados aspectos do registro arqueológico a formações sociais, como uma espécie de lista diagnóstica, pode ser rígido demais e mascarar as dinâmicas sociais do passado (Neves, 1999, 2008).

Ao mesmo tempo, disciplinas como a Antropologia destacam o papel da Arqueologia em um momento em que os povos nativos vêm usando a sua ligação histórica com o passado para assegurar o seu futuro (Viveiros de Castro, 2002: 341), alertando aos perigos de uma "perversão arqueológica" onde culturas indígenas contemporâneas são avaliadas a partir de um padrão caracterizado por centralização política e agricultura intensiva do passado pré-colombiano, sugerindo, deste modo, olhar as bases culturais e as expressões sociopolíticas dos cacicados à luz dos conhecimentos das sociedades indígenas do presente (Viveiros de Castro, 2002: 343).

É dentro deste quadro que mais recentemente os estudos sobre as cerâmicas da Amazônia antiga têm demonstrado o potencial informativo contido nas iconografias a respeito das visões de mundo das populações pré-coloniais (Barreto, 2009; Gomes, 2014, 2016; Oliveira, 2016). Estes estudos são orientados por trabalhos desenvolvidos no âmbito da Etnologia ameríndia que reconhecem a existência de uma estética pan-amazônica orientada principalmente por um fundo cosmológico caracterizado pela ontologia da predação e com referência especial à corporalidade (Lagrou, 2007, 2011, 2013; Severi, 2013; Taylor e Viveiros de Castro, 2006), onde o caráter transformacional dos corpos, típico das ontologias multinaturalistas amazônicas, é percebido na instabilidade das formas e no contraste constitutivo entre uma interioridade e uma exterioridade que não são 
necessariamente coincidentes, onde um ser humano pode se esconder num corpo não-humano e um não-humano pode ser esconder em um corpo humano (Lagrou, 2007; 2013, Viveiros de Castro, 2002).

Barreto $(2009,2014)$, por exemplo, propõe que certas urnas funerárias marajoara com características híbridas de humanos e animais, e cujos corpos são compostos por braços que aludem a serpentes, ombros sugeridos por apliques modelados em forma de cabeças de pássaro e olhos destacados por incisões em forma de escorpião sejam interpretadas à luz dos conceitos ameríndios de corporalidade (Barreto, 2014: 127), seja como corpos compostos a partir de partes anatômicas de diferentes espécies e em processo de transformação física e espiritual, ao modo da técnica de kenning, frequentemente vista na iconografia das populações andinas, e melhor descrita no capítulo 4, seja aludindo ao modo construtivista dos ameríndios de fabricar corpos a partir de partes corporais de diversos seres, como sugere Santos Granero (2012).

Os estudos iconográficos desta autora (Barreto, 2009, 2014) mostram que na cerâmica marajoara há uma série de recursos gráficos que são empregados para mostrar a capacidade transformativa dos corpos e estimular a visão de outros seres. Certas urnas funerárias que mesclam características humanas e animais, por exemplo, possuem os seus corpos compostos por meio do desdobramento que cria duas metades idênticas, com duas frentes, cuja junção e encadeamento revelam novas figuras.
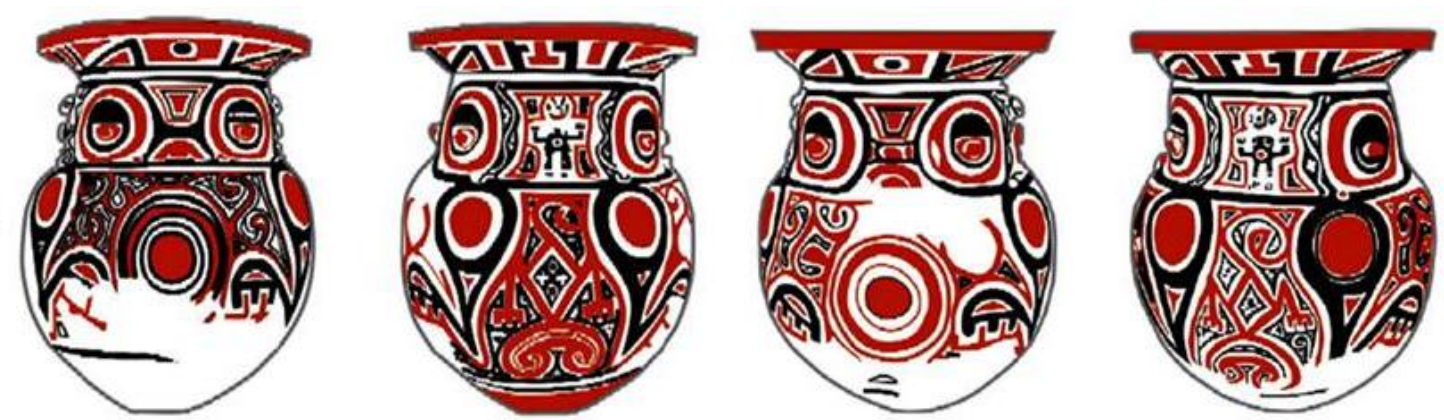

Figura 3: Urna funerária estruturada pelo desdobramento de uma figura antropozoomorfa. Nota-se que por meio da junção das figuras espelhadas outra figura é mostrada. Fonte: Barreto, 2009. 
Diante deste cenário, o papel do estilo enquanto replicador de ideologias ${ }^{3}$ pode ser reconhecido, mas pensado menos como parte de uma estratégia de legitimação de poder político de grupos sociais, e mais relacionado a conceitos subjacentes à relação entre humanos e animais, reprodução e transformação corporal, o que é característico das ontologias baseadas na predação e na transubstanciação entre seres (Barreto, 2009, 2014; Oliveira, 2016).

Portanto, uma abordagem da arte das sociedades pré-coloniais, sobretudo, daquelas que sugerem terem tido um perfil sociopolítico complexo, à luz dos conhecimentos a respeito das manifestações artísticas e das ontologias ameríndias pode aumentar a nossa compreensão sobre estas sociedades, sobretudo, em relação às suas visões de mundo expressas nas iconografias, concepções que estas sociedades fazem de si mesmas, as suas concepções do que é ser humano, do que é um corpo, e o que a imagem de um corpo pode evocar, representar e fazer, em contextos amazônicos.

\subsubsection{As tangas cerâmicas}

Entre os objetos arqueológicos mais conhecidos dentro da Arqueologia brasileira e, sobretudo, da Arqueologia amazônica, estão as tangas cerâmicas da fase marajoara. Especialmente no que diz respeito aos artefatos da fase marajoara esta categoria de objetos é uma das mais emblemáticas, estando completamente relacionada àquela fase.

É uma categoria de objetos que tem atraído a atenção dos pesquisadores desde que a cerâmica marajoara passou a ser explorada no início da década de 1870. E desde então diversos autores dedicaram especial atenção ao seu estudo, como por exemplo, Charles. F. Hart (1876), Ladislau Netto (1885), Antonio Mordini (1929), Helen C. Palmatary (1950), Napoleão Figueiredo (1956), Betty Meggers e Clifford Evans (1957), Frederico Barata (1968), Silvia M. de carvalho (1975), Denise

\footnotetext{
${ }^{3}$ Para Shanks e Tilley (1992) a ideologia é um aspecto tangente à uma relação de desigualdade e que esconde as contradições existentes nos interesses de um grupo dominante. Com isto, as suas principais características são: representar um universal que é parcial; representar um coerente que é contraditório; representar um permanente que está em mudança; representar um natural e necessário que, na verdade, é cultural e contingente (Shanks e Tilley, 1992: 130). Nas sociedades complexas, o estilo tem sido reconhecido enquanto uma das principais ferramentas para replicação da ideologia, sendo um aspecto central na definição da hierarquia e do exercício do poder. Deste modo, a iconografia expressa na cultura material é frequentemente utilizada pelas elites para expressar o seu status social (Hegmon, 1992: 528-529) bem como para vinculá-las aos entes sobrenaturais, como ancestrais e seres míticos.
} 
Schaan (1996, 2001, 2003, 2004), Cristiana Barreto (2004), André Prous e seus colaboradores (Prous e Lima, 2011; Rodrigues et al, 2011; Prous, 2013;) além de um amplo estudo não publicado realizado por Heloísa Alberto Torres ${ }^{4}$. Estes estudos têm sido norteados por duas perguntas, a dizer: para que as tangas eram usadas e qual era o significado dos seus grafismos?

As tangas marajoara chamam a atenção por terem sido fabricadas de argila, diferentemente do que ocorre entre os povos indígenas atuais que fabricam as suas vestimentas, entre elas as tangas, de tecido e fibras vegetais. Há diferenças no tratamento de sua superfície: um tipo de tanga possui a sua superfície ornada com grafismos pintados em vermelho ou marrom sobre um engobo de cor clara que pode variar entre o branco, o creme e o alaranjado, e outro tipo apenas pintado de vermelho ou bege/ alaranjado ${ }^{5}$. Elas possuem o formato triangular convexo e com orifícios em suas extremidades por onde eram passados cordões para prendê-las ao corpo, e cujo atrito produziu marcas de desgaste. Vários autores correlacionam a grande variação em relação a seu tamanho e a sua curvatura à anatomia do corpo e à idade de quem as usava (Barreto, op.cit; Meggers e Evans, op.cit.; Palmatary, op.cit.; Schaan, op.cit.)
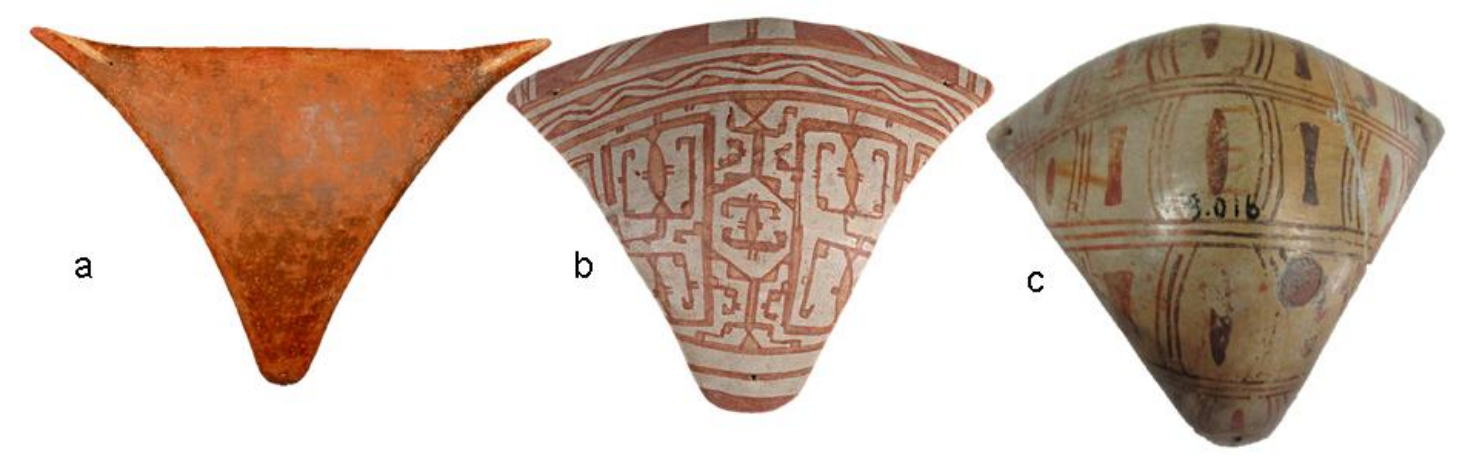

Figura 4. Tipos de tangas. a: Tanga coberta com engobo vermelho. b, c. Tangas com grafismos, cobertas com engobo claro e grafismos em tonalidade de vermelho. a, b. Coleção ICBS/MAE-USP, Museu de Arqueologia e Etnologia da USP, São Paulo . c. Museu Nacional, Rio de Janeiro.

Muitos autores aceitam que as tangas eram objetos de uso exclusivamente feminino (Barreto, 2004; Hartt, 1876; Evans e Meggers, op.cit.; Schaan, op.cit.;

\footnotetext{
${ }^{4}$ Consultamos os estudos de Heloísa Alberto Torres no setor de documentação do Museu Nacional, no Rio de Janeiro.

${ }^{5}$ No capítulo 3 , com base em nossa análise, discutiremos mais detalhadamente a respeito das cores empregadas na confecção dos grafismos e do engobo nas tangas.
} 
Mordini, 1929; Netto, 1985; Palmatary, 1950; Prous e Lima, op.cit.). Apesar disto, não há dados suficientes que sustentem esta relação.

Meggers e Evans (op.cit.) escavaram pelo menos 3 sepultamentos com tangas associadas nos quais os ossos dos indivíduos foram examinados. Em uma urna escavada no teso Guajará havia os ossos de um individuo do sexo feminino e outro do sexo masculino com uma tanga vermelha associada provavelmente ao homem (Meggers e Evans, 1957:273) e em outro sepultamento no mesmo teso foi escavada uma tanga alaranjada associada a um indivíduo cujo sexo não foi identificado; em um sepultamento escavado no teso Camutins uma tanga com grafismos foi escavada dentro de uma urna associada a ossos que foram identificados como do sexo feminino. Schaan (2004) escavou 24 sepultamentos em urnas funerárias no teso Belém, do conjunto Os Camutins, em seis deles havia tangas associadas. No entanto, nenhum destes seis apresentou vestígios ósseos bem conservados para que o sexo pudesse ser determinado.

Além disto, José Seixas Lourenço, professor da Universidade Federal do Pará, escavou em 1977, no teso dos Bichos, um sepultamento em uma urna do estilo Pacoval com o crânio de um indivíduo do sexo masculino ${ }^{6}$ associado a uma estatueta e uma tanga com grafismos (Roosevelt, 1991:393). Do mesmo modo, o Museu Paraense Emílio Goeldi recebeu uma doação de um crânio masculino ${ }^{7}$ que foi coletado em 1972 no teso Camutins dentro de uma urna Joanes Pintado, associado também a uma tanga pintada.

Uma vez que as análises osteológicas dos indivíduos sepultados com tangas são insuficientes para se afirmar que elas tenham sido usadas por homens ou mulheres, tem se recorrido a analogias etnográficas para explicar (Evans e Meggers, op.cit.; Schaan, 2003). Usa-se frequentemente como exemplo os tapa-sexos utilizados por populações indígenas da Amazônia, como os Chama, grupo Pano do Rio Ucayali, cujo uso de um tapa-sexo cerâmico por moças na puberdade durante um ritual específico foi registrado etnograficamente. Neste ritual, meninas púberes eram reunidas durante a lua cheia e na manhã seguinte eram pintadas, entorpecidas com bebida e cada uma se sentava em um banco onde uma mulher mais velha

\footnotetext{
${ }^{6}$ Este crânio foi analisado por Roosevelt (1991) e pela bioarqueóloga Cláudia Cunha (comunicação pessoal) que comprovaram se tratar de um indivíduo do sexo masculino.

${ }^{7}$ Segundo a bioarqueóloga Cláudia Cunha (comunicação pessoal), quem analisou o crânio, trata-se de um indivíduo do sexo masculino.
} 
cortava e enterrava o clitóris e lábios vaginais. Após isto eram defloradas com um pênis de argila e, após isto, eram isoladas em sua cabana por um mês, vestindo um tapa-sexo de cerâmica de forma oval (Steward e Métraux, 1948:585). Esta analogia levava em consideração o fato de ambos serem feitos de cerâmicas. Entretanto, não há maiores descrições destes tapa-sexos que relatem as suas características e, apesar destas analogias, não são conhecidos objetos semelhantes em cerâmica em nenhuma outra cultura, etnográfica ou arqueológica, das terras baixas da América do Sul, e, portanto isto parece ser uma prática específica de Marajó.

Com as discussões sobre os cacicados em Marajó tem sido proposta por alguns autores (Roosevelt, 1991; Schaaan, op.cit.) uma divisão entre elite e pessoas comuns. As estruturas habitacionais, uma cerâmica utilitária, mais simples, além de sepultamentos e cerâmica decorada, encontrados nos tesos, demonstrariam que uma elite vivia e sepultava os seus mortos ali como forma de se manter conectada aos seus ancestrais e, deste modo, justificar o seu poder. Diante disto, toda a cerâmica decorada seria de uso exclusivo desta elite.

Diante disto, as tangas seriam itens destinados à elite, mais especificamente às mulheres, e as diferenças observadas em relação à sua decoração foram associadas a diferenças de idade entre as mulheres (Schaan, 2003, 2004). Schaan (2003) sustenta que as tangas monocromáticas possuem uma curvatura maior do que a daquelas com grafismos, e seriam também mais frequentes em sepultamentos em grandes urnas funerárias profusamente decoradas, mostrando que poderiam ter sido usadas por mulheres mais velhas.

As tangas com grafismos que, segundo a autora, possuem uma curvatura menor, teriam sido usadas por mulheres mais jovens, cuja identidade e status não haviam ainda sidos firmados, durante rituais de iniciação. Deste modo, haveria toda uma iconografia nas tangas relacionada à mulher, ao papel feminino na sociedade. Os seus diferentes campos gráficos trariam informes abrangentes sobre gênero, idade, identidades individuais e sobre o papel da mulher (Schaan, op.cit.)

Um dos campos gráficos amplamente discutidos pela autora é aquele que em nossa pesquisa chamaremos de banda 2, e que se encontra melhor descrito no capítulo 4. O padrão gráfico deste campo, segundo a autora, veicula motivos identificados como "pele da serpente" e que recobrem o corpo de serpentes figuradas mais naturalisticamente na cerâmica marajoara, estariam também 
presentes também em uma ampla gama de objetos. A associação de grafismos relacionados a serpentes em objetos femininos, como as tangas, destacaria a importância do papel das mulheres. Apoiando-se nas mitologias dos indígenas amazônicos onde a cobra é considerada um ser feminino e está relacionada à fertilidade, a autora pondera que a recorrente associação de cobras em itens de uso feminino estaria relacionada a uma importância do gênero feminino, mais especificamente das mulheres da elite, para o equilíbrio das relações entre sociedade humana e ciclo de vida dos animais, considerando-se que na mitologia marajoara a serpente estivesse relacionada à procriação dos peixes (Schaan, op.cit.).

Entretanto, não há consenso quanto às figurações da "pele da serpente" nas tangas. Autores como Prous e Lima (2011: 259) discordam e a própria Schaan (2009: 274) registra a existência de jacarés e escorpiões neste padrão. Aliás, as figuras dispostas graficamente nas tangas, assim como a iconografia marajoara no geral, têm sido relativamente debatidas. Hartt (1876: 23) sugeriu que a forma como os desenhos são dispostos em certos campos das tangas era uma convenção para representar a "cara" humana. Para Torres (1940: XIII) em certas tangas a imagem figurada é a de uma face estilizada de jaguar. Em um estudo mais amplo das tangas Prous e Lima (2011:240) sugerem figurações de "caras" humanas ou animais, algumas com partes anatômicas compostas por cobras ou sauros.

Carvalho (1976) percebeu que elementos zoomorfos estão amplamente relacionados à composição da figura humana na iconografia da cerâmica marajoara. Em um estudo sobre as figurações de jacarés na cerâmica marajoara a autora demonstrou que muitas figuras que aparecem na composição das imagens são estilizações de figuras mais icônicas daquele réptil. Estas figuras compõe o corpo de várias urnas, estruturando braços, pernas e outras partes anatômicas. Segundo a autora, é muito comum na iconografia desta cerâmica a formação de faces estilizadas a partir do desdobramento da figura do jacaré, onde, por exemplo, as suas pernas em forma de volutas podem formar os lados de duas faces humanas opostas.

Deste modo, parece-nos claro que não se trata de diferenciar se as figuras vistas na iconografia marajoara são de humanos ou são de animais, mas sim de 
compreender o processo de formação destas imagens, de compreender a sua sintaxe, o modo como funcionavam em seus contextos.

Todos os autores que trataram da iconografia marajoara, mesmo aqueles que voltaram as suas atenções para um ou outro tipo de figura, reconhecem o caráter compósito das imagens e dos corpos figurados. Neste sentido, estas imagens e corpos não estariam expressando mais uma noção de corporalidade que recai especialmente na transformabilidade dos corpos?

Voltando às tangas, propomos deslocar a tônica dada a estes objetos enquanto itens de uma elite para pensá-los como objetos de composição, transformação e fabricação corporal. Além das tangas uma variedade de itens relacionada à composição e transformação do corpo tem sido registrada nos contextos da fase marajoara, como alargadores cerâmicos de orelhas, labretes de nefrita e cerâmica, colares de contas cerâmicas e de pedras, pingentes em cerâmica e nefrita, pelotas de pigmentos e pequenos potes com pigmento, o que demonstra uma preocupação com a produção e fabricação corporal naquela sociedade. 


\section{CAPÍTULO 2.}

\section{AGÊNCIA E TRANSFORMAÇÃO NA ARTE}

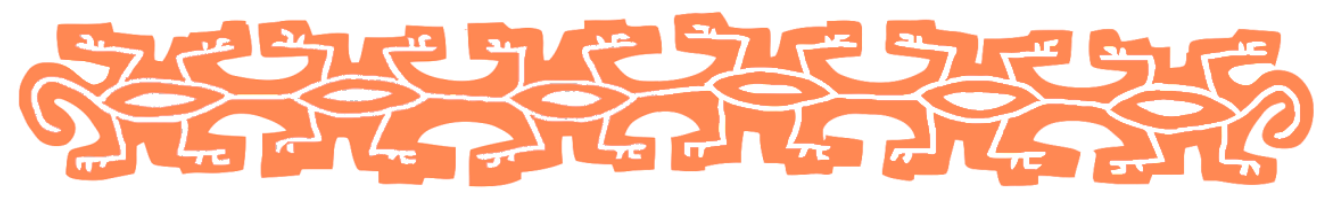

Um grande percalço que se coloca frente aos estudos das coleções museológicas diz respeito ao fato de que muitas delas foram retiradas de seus diversos contextos de maneiras assistemáticas, com pouco ou nenhum registro. No caso das coleções provenientes da Amazônia antiga, são bem conhecidos os modos como foram formadas. A formação destas coleções, na maioria das vezes, era pautada na coleta de peças com maior apelo estético, ou por moradores ou por colecionadores, às vezes para fins expositivos. Com isto, os contextos nos quais os artefatos eram encontrados, bem como a sua procedência precisa, eram desconsiderados. Isto resultou em diversas coleções descontextualizadas, mas que ao longo do tempo foram tomadas como representativas de culturas extintas, cujo maior potencial, além do expositivo, era ilustrar atributos diagnósticos que pudessem levar à formação de tipos, sobretudo, com base em seu acabamento superficial e modos de decoração.

A partir das últimas décadas tem havido um significativo esforço para se explorar estas coleções com novos olhos. Nisto, os estudos têm se voltado para a iconografia, aproveitando o fato de que estas coleções fornecem muitos objetos inteiros ou semi-inteiros, propiciando a análise do projeto de design do objeto como um todo, ao contrário de coleções de escavação, com muitos fragmentos e a partir dos quais as reconstituições podem ser bastante hipotéticas. No caso das coleções de cerâmica marajoara, o potencial destas coleções foi explorado por meio de estudos iconográficos por Schaan $(1996 ; 1997)$ e Barreto (2009) e também por Troufflard (2010). Outros esforços com este intuito têm sido feitos para outras cerâmicas da Amazônia, como por exemplo, os estudos de Oliveira (2016) e de Gomes $(2001,2016)$. 
Esforços deste tipo vão além das fronteiras da Amazônia brasileira, como por exemplo, o estudo de Reichell-Dolmatof (1990) sobre os objetos do Museu do Ouro, em Bogotá, Colômbia. É conhecido que estes objetos carecem de informação acerca de sua procedência e de dados sobre as condições em que foram encontrados. Dadas estas lacunas, Reichel-Dolmatoff tenta explorar o potencial destes objetos à luz dos conhecimentos etnológicos sobre as culturas históricas e contemporâneas. Neste sentido, o autor sugere que as representações figurativas da ourivesaria pré-colombiana formam um complexo de arte xamânica relacionado ao tema da transformação, o que pode ser compreendido à luz de um complexo de ideias relacionadas ao xamanismo.

Este esforço em se explorar coleções arqueológicas à luz de conceitos e ideias da etnologia pode parecer inadequado por se incorrer nas falácias da analogia etnográfica, projetando conhecimentos sobre as cosmologias do presente para interpretar as do passado, contudo, considerando-se algumas esferas resistentes da relação entre imagem e identidade nas sociedades ameríndias em geral, o exercício pode ser bastante frutífero.

Conforme Barreto (2009:29-30) sugere para o contexto amazônico, o estudo de certos temas possibilita explorar teorias mais generalizantes que podem servir de fundo comum para todas as sociedades amazônicas e ainda servir como uma medida para explicar a variabilidade das diferentes sociedades registradas etnograficamente e, esta explanação da variabilidade pode ser projetada para a análise de certas categorias de objetos arqueológicos. O que é importante destacar aqui é que não se trata de lançar mão da analogia etnográfica para se interpretarem objetos e contextos arqueológicos, mas é, portanto, conforme aponta Barreto (op.cit.), fazer uso das lições da Etnologia ameríndia, isto é, aproveitar todo o potencial explicativo do corpo de teorias e generalizações desenvolvidas a partir da observação das sociedades ameríndias para a organização e análise de um conjunto de objetos arqueológicos.

Estas lições da Etnologia ameríndia, na Arqueologia, têm sido aproveitadas principalmente por Barreto (2009), por Gomes $(2014,2016)$ e mais recentemente por Oliveira (2016). É importante salientar que neste caso também se tem tentando dialogar com a antropologia da arte e, sobretudo, com a antropologia da arte 
desenvolvida sobre os povos amazônicos. No presente trabalho o corpo teórico adotado partirá destas perspectivas mencionadas.

\subsection{Arte e Agência no mundo ameríndio}

A tentativa de entender o significado e o porquê dos grafismos das artes dos povos indígenas culminou no emprego de várias abordagens estruturalistas (LeviStráuss, 2008 [1958]) ao longo das últimas décadas. Nisto, o uso de representações geométricas para descrever os seres mitológicos e uma variedade de idéias culturais foram observadas etnograficamente por Nancy Munn (1973) entre os Walbiri australianos. Munn identificou nos desenhos feitos pelos Walbiri na areia e pedra a existência de uma linguagem icônica visual utilizada para a comunicação e relacionada à história de seus antepassados totêmicos. Tais grafismos não eram simplesmente de uso sagrado ou cerimonial, mas eram usados para conferir intensidade e estabilidade visual às conversas e histórias. Partindo de um número finito de signos gráficos icônicos que se assemelhavam a seus referentes, os Walbiri elaboravam desenhos de diferentes complexidades e conteúdo semântico. Cada um desses sinais, chamados de "unidade mínima significativa", possuem uma gama relativamente ampla de significados, deste modo, a compreensão do seu significado depende da sua posição dentro do contexto e da relação com os outros elementos.

Este trabalho teve vários desdobramentos em contextos etnográficos e arqueológicos sulamericanos (Müller, 1992; Vidal, 1992; Schaan, 19967, 1997). Em contexto ameríndio, por exemplo, Müller (1992) em sua descrição dos grafismos dos Assurini do Xingu, identificou unidades mínimas significativas que formam motivos maiores. Já para contextos arqueológicos o método de isolamento das unidades mínimas de significação tem sido empregado em contextos mesoamericanos, andinos e amazônicos (Brotherston, 1997; Golte, 2009; Schaan, 1996, 1997 e 2007).

É na tentativa de se percorrer um caminho diferente que uma abordagem voltada para a agência dos objetos, conforme proposta por Gell (1998), pode se fazer interessante para objetos de contextos arqueológicos, pois permite que estes sejam analizados enquanto veículos de negociação e poder (Barreto, 2009; Quilter, 2007). A ideia de se tratar objetos como agentes tem sido explorada nos mais diferentes contextos arqueológicos (Barreto, op.cit.; Gosden, 2005; Quilter, op.cit.; 
Osborne, 2007; Stewart, 2007; Wengrow, 2007; Winter, 2007). Para a Arqueologia, esta proposta pode ser útil porque possibilita entender o que e como os objetos mobilizam socialmente. Uma proposta analítica que entende os objetos como agentes sociais está em consonância com a ideia do papel ativo da cultura material nas relações sociais, de modo que os artefatos formam um meio poderoso para agir e reestruturar as práticas sociais, conforme proposto por Shanks e Tilley (1992).

A introdução de uma abordagem que destaca objetos como agentes sociais, na Arqueologia, foi amplamente favorecida pela crítica pós-moderna que enfatizava a agência dos indivíduos, como forma de se assumir a historicidade, em detrimento de processos comuns a toda humanidade (Hodder, 1985; Shanks, 2008). Os debates iniciados nos anos 80 destacavam a agência dos indivíduos como uma maneira de se afastar dos conceitos neo-evolucionistas e dos processos transculturais caros às abordagens processuais.

A antropologia da arte, na tentativa de lidar com as artes das sociedades não ocidentais, por muito tempo se debruçou sobre o problema conceitual da categoria "arte" visando um conceito que fosse útil em categorias antropológicas de análise (Morphy, 1994; Ingold, 1994). Nesta batalha conceitual, as artes não ocidentais tiveram de ser posicionadas em relação a três aspectos diferentes da definição europeia de arte: uma definição institucional, uma definição em termos de atributos dos objetos e a definição em termos da intenção (Morphy,op.cit.).

Os embates relacionados ao encaixe dos objetos de culturas não ocidentais nestas categorias de arte e a busca por categorias que possibilitassem análises antropológicas tiveram diversos desdobramentos. É neste contexto que o debate relacionado ao uso da estética como uma categoria de análise tomou corpo, sobretudo, no que diz respeito ao uso desta enquanto uma categoria transcultural ${ }^{8}$.

Gell (1998: 2-3) questionando a aplicabilidade transcultural da estética afirma que a elucidação dos sistemas estéticos não-ocidentais não constitui uma "antropologia" da arte. A "antropologia da arte" deve visar o contexto social da produção, circulação e recepção da arte, e não a avaliação estética de obras de arte específicas. Esta disciplina não pode se deter no estudo dos princípios estéticos de

\footnotetext{
${ }^{8}$ Este assunto foi bem debatido no capítulo Aesthetics is a cross-cultural category do livro Key debates in anthropology organizado por Tim Ingold. Howard Morphy, Jeremy Coote, Marcus Banks se mostram a favor da aplicabilidade transcultural da estética, enquanto Joanna Overing e Peter Gow se opõem.
} 
uma ou outra cultura, mas sim na mobilização de princípios estéticos no decorrer da interação social.

Neste sentido, propõe que certos objetos possuem características que levam ao encantamento e à sedução, chamadas de tecnologias de encantamento (Gell, 1992). De acordo com isto, os objetos de arte demonstram certo nível de excelência alcançado tecnicamente, na medida em que esta excelência diz respeito não simplesmente às suas características como objetos, mas às suas características enquanto objetos que são produtos de técnicas. Neste sentido, a arte é um sistema técnico que produz consequências sociais decorrentes da produção desses objetos. Este sistema técnico, ou tecnologia do encantamento, é essencial à reprodução e à transformação de valores sociais por ser um sistema de conhecimento de técnicas de produção eficazes, que age dentro de uma rede social de intenções e necessidades coletivas.

A eficácia dos objetos de arte é o resultado do encantamento da tecnologia, ou seja, os processos técnicos são vistos como mágicos, de modo que os produtos desses processos técnicos pareçam portadores de poder mágico. Deste modo, o objeto não é ofuscante como objeto físico, mas como uma amostra da vocação artística tornada visível mediante magia. É o modo como os objetos são elaborados que é a fonte do poder que eles exercem, uma vez que se sugere que foram produzidos por meios mágicos, ou seja, eles personificam os processos técnicos pelos quais foram produzidos, e aí reside o seu poder de fascinação (ibidem).

A partir disto, este autor (Gell, 1998:7-8) postula uma "teoria da arte" antropológica partindo da premissa que as teorias antropológicas devem ser teorias sobre as relações sociais. Desta maneira, a "antropologia da arte" deve ser o estudo teórico das "relações sociais na vizinhança dos objetos que atuam como mediadores da agência social", e para que a antropologia da arte seja antropológica, ela tem que partir da ideia de que os objetos de arte equivalem a pessoas, ou, mais precisamente, a agentes sociais.

A proposição que considera os objetos de arte como pessoas tem como base a economia do dom de Mauss (2003), uma vez que as prestações ou "dons" são tratados na teoria da troca de Mauss como extensões da pessoa. O conceito de pessoa distribuída formulado por (Gell, op.cit.) tem como base o conceito de pessoa 
fractal (fractal person) de Wagner (1991) e as ideias de Strathern (2006; 2013) que versam sobre o problema da recursividade (partible person) na Melanésia.

Para Gell (op.cit.), os objetos devem ser compreendidos enquanto índices em uma cadeia de relações sociais onde ocupam o lugar de agentes ou pacientes, dependendo de sua posição nesta cadeia, ou seja, é a proximidade que estabelece a possibilidade de que um objeto se estabeleça como agente. O conceito de índice, originário da semiótica de Peirce (2010), é importante por que possibilita fugir do significado de uma obra de arte ou daquilo que ela pretende comunicar, se preocupando ao invés, com as relações do objeto e qual a sua capacidade de agir sobre o mundo e transformá-lo. ${ }^{9}$

Ainda segundo o autor, o índice material (a "coisa" física, visível) permite a abdução da agência, um tipo de operação cognitiva que possibilita uma causal inference of some kind, or an inference about the intentions or capabilities of another person (Gell, 1998:13). A utilidade deste conceito, para Gell, está no fato de que ele designa uma classe de inferências semióticas, que são, por definição, totalmente distintas das inferências semióticas que usamos no entendimento da linguagem, cuja compreensão literal é uma questão de observar convenções semióticas (Gell, 1998:14). Assim, a abdução da agência possibilitaria abrir mão de significado, interpretação e representação. Entretanto, conforme Lagrou (2007: 56) pontua, os índices de arte de Gell só se tornam agentes, porque há algum tipo de sentido e contexto de interpretação que possibilitam os artefatos ou imagens a agirem.

Deste modo, Gell não abandona totalmente a dependência do significado uma vez que o caráter abdutivo da agência possibilita algumas inferências interpretativas ao receptor. Nisto, não há a exclusão dos conceitos de Peirce de índice ou ícone, mas somente do conceito de símbolo, trabalhando com os conceitos de índice e ícone de forma diferente. Conforme aponta Lagrou (2007:14-15), não é preciso distinguir índice de ícone na relação pragmática e interacionista do seu modelo. Pois todo ícone já é na verdade um índice: pois a imagem age sobre a pessoa, partilha nas qualidades daquilo que é imagem (Lagrou, op.cit.).

\footnotetext{
${ }^{9}$ Peirce em sua teoria geral sobre a representação dividiu os signos em ícone, índice e símbolo. O ícone é um signo que possui algum tipo de semelhança perceptiva com aquilo que representa, como por exemplo, a fotografia de uma pessoa. Já o índice indica a presença do que ele representa baseado em evidências de causalidade ou de proximidade, como por exemplo, o cata-vento que indica o vento, ou a fumaça que indica o fogo. 0 termo "símbolo" é reservado apenas para aquelas ocasiões em que a relação entre o significante e o significado é puramente arbitrária, podendo se referir ao representado por associação de ideias produzidas por uma convenção.
} 
Por trás do sistema de ação de Gell - formado a partir dos conceitos da semiótica peirciana - está o problema da representação, ou melhor, da presentificação $^{10}$. A presença, para Gell, é fundamental para que ocorra saliência cognitiva. A presentificação se concentra no estatuto de pessoa que os objetos de arte possuem, logo, se eles são pessoas, eles não representam, mas agem (Demarchi, 2009:187).

É importante destacar que este problema da representação é um tema que tem chamado a atenção dentro da Etnologia há bastante tempo. A noção de sociedades de máscaras de Levi-Strauss (2008 [1958]), por exemplo, recai sobre sociedades onde a arte não é uma arte de representação, mas sim de apresentação. O exemplo paradigmático disto é aquele dado pelo autor sobre a pintura facial Kadiwéu, onde o desenho da pintura facial não representa o rosto, mas é o rosto propriamente dito, pois no pensamento daquele povo a pintura facial é o rosto, pois é ela que confere o ser social e a dignidade humana.

O problema da representação também está por trás das características que definem a ontologia dos espíritos, como apontado por Viveiros de castro (2006). Entre os ameríndios, por exemplo, a imagem dos espíritos é fluida, eles nunca se deixam capturar, mas sim geram mais e mais imagens de si, pois não há uma imagem verdadeira ou única deles. Esta característica é bastante interessante porque aponta para a natureza indéxica dos espíritos e para a sua capacidade de se distribuir em várias peles. Conforme aponta Viveiros de Castro

O que define os espíritos, em certo sentido, é indexarem os afetos característicos daquilo de que são a imagem sem, por isso, parecerem com aquilo de que são a imagem: são índices, não ícones (Viveiros de Castro, 2006: 325).

Em relação à distribuição da pessoa, ou seja, as diversas peles que uma pessoa pode assumir, Gell (op.cit.) exemplifica da seguinte forma:

An ambassador is a spatio-temporally detached fragment of his nation, who travels abroad and with whom foreigners can speak, 'as if' they were speaking to his national government. Although ambassadors are real persons, they are also 'fictions', like pictures, and their embassies are fictional mini-states within the state; just as pictures show us landscapes and personages who are 'not really there'. Although the Chinese ambassador in London does not look like China, or the Chinese government or people, he does have to be visible, and

\footnotetext{
10 Segundo Demarchi (2009: 186) caráter não representativo das imagens e obras de arte e sua ação cognitiva.
} 
"he does visibly represent China on official occasions. He does not look like China, but in London, China looks like him (Gell,1998: 98).

Uma consequência desta proposição é a de que se a noção de pessoa engloba os seus itens materiais e imagens, a pessoa pode também se distribuir por meio dos seus itens e imagens (agora índices), no espaço e também no tempo. Decorre daí a ideia de que todo índice é também icônico, ou seja, que estes itens e imagens se parecem com os seus donos, mesmo que não sejam semelhantes a eles. Assim, a noção de representação não se baseia na noção de semelhança icônica, mas sim na noção de índice.

A ideia é que, se a aparência das coisas pode ser considerada como parte material delas, então o tipo de influência sobre uma pessoa ou coisa pelo acesso à sua imagem é comparável ao efeito obtido pelo acesso a uma parte física delas; especialmente se introduzirmos a noção de que as pessoas podem ser "distribuídas", ou seja, todas as suas "partes" não estão conectadas fisicamente, mas estão distribuídas em todo o ambiente, como a fina casca descartada de uma cigarra, que é ao mesmo tempo imagem e parte da criatura viva (Gell, 1998:105106). Esta ideia é particularmente interessante quando se lida com as ontologias dos povos amazônicos onde é generalizada a ideia de que os corpos são constituídos por outros corpos, ou por partes dos corpos de uma miríade de seres, o que detalharemos melhor em um momento oportuno ainda neste capítulo.

\subsubsection{Vida e morte dos objetos}

A proposta de Gell (op.cit.) em tratar os objetos como pessoas é bem útil, considerando-se a perspectiva ameríndia. A Antropologia desde os seus primórdios se debruça sobre as discussões a respeito do "animismo", tendo dado relevo para a reflexão sobre as relações entre pessoas e coisas que se parecem ou funcionam como pessoas (Lagrou, 2007:48). Esta relação entre objetos e pessoas se encaixa muito bem com o material amazônico, já que

É na relação entre o esquema conceitual de um povo, suas interações sociais e a materialização destes em artefatos e imagens que se encontra a fertilidade do método proposto (Lagrou, 2007: 49). 
Uma abordagem que considera a relação entre pessoa e objetos, sob a ótica da Etnologia ameríndia, deve considerar que refletir sobre a arte entre os ameríndios equivale a pensar sobre a pessoa e sobre o corpo, já que objetos, pinturas e corpos se relacionam no mundo ameríndio, onde a pintura é feita para aderir aos corpos e os objetos são feitos para completar a ação ritual (Lagrou, 2007: 50). Para Miller (2013) uma teoria amazônica sobre os objetos deve ser uma teoria sobre a pessoa. Em sua pesquisa junto aos Mamaindê ${ }^{11}$ esta autora verificou que os objetos são concebidos como pessoas ou como componentes das pessoas, já que relacionam certas pessoas com outras espécies de sujeitos.

A etnografia atenta ao fato de que nas ontologias ameríndias amazônicas os objetos possuem um ciclo similar ao de todos os seres vivos. Eles são trazidos à vida por meio do trabalho artesanal ou por meio de procedimentos rituais, atuam ativamente em uma miríade de contextos econômicos, sociais e cerimoniais e, quando se desgastam ou não podem mais cumprir as funções para as quais foram feitos, são deixados para morrer ou são mortos ritualmente (Lagrou, 2007; Santos Granero, 2012).

A Etnologia, mais recentemente, tem sugerido que os objetos devem ser entendidos como seres dotados de agência, subjetividade, intencionalidade ou certos atributos de pessoalidade e possuidores de uma vida social (Santos- Granero, 2012; Lagrou, 2007). Por meio desta reflexão tem sido percebido que, entre os ameríndios, nem todos os objetos são subjetivos da mesma forma, alguns possuem almas fortes e autônomas, enquanto outros possuem somente uma fraca subjetividade, características estas que dependem da quantidade e qualidade da substância anímica que possuem (Santos Granero, 2012: 30) e mesmo das suas propriedades sensíveis como brilho, dureza, cor, odor ou emissão de sons (Neto, 2008b). Isto está de acordo com as teorias indígenas sobre a personitude que concebem pessoas como seres que possuem alma ou vitalidade, o que é crítico para que tenham consciência, além de habilidade de pensar. Os objetos que não possuem estes atributos dependem de algum tipo de intervenção humana para que possam ser subjetivados ou tornarem-se pessoas (Santos Granero, op.cit.).

A sugestão de que a subjetivação dos objetos que não possuem almas autônomas depende sempre de outro sujeito, coincide com a sugestão de Gell

\footnotetext{
${ }^{11}$ Grupo que habita o limite norte do vale do rio Guaporé, de língua Nambicuara, e que conta hoje com cerca de 190 pessoas, a maioria vivendo em uma única aldeia situada entre os rios Pardo e Cabixi (Miller, 2013).
} 
(op.cit.) de que os objetos só podem ser entendidos como agentes ou pacientes a partir de uma cadeia de relações sociais. Segundo Santos Granero (2012: 31), a subjetivação destes objetos poderia acontecer através do contato íntimo com os seus donos através da difusão gradual das suas substâncias anímicas para os seus pertences mais pessoais. A subjetivação por meio do processo de animização é considerada uma forma de corporificar (embody) os objetos para que se tornem uma extensão dos corpos de seus proprietários, o que seria uma noção amplamente difundida na Amazônia indígena (Santos Granero, Op.cit.).

Nas concepções ameríndias os limites de uma pessoa ultrapassam a esfera corporal, já que com o passar do tempo os objetos pessoais se tornam parte de seu corpo. Entre os Mamaindê, por exemplo, os adornos corporais são associados ao espírito, e assim, são considerados parte da pessoa, a tal ponto que devem ser zelados para que não se percam ou sejam danificados, caso contrário, o dono pode ficar seriamente doente, ou até mesmo morrer. É por esta razão que, durante as práticas xamanísticas que visam reunir o espírito ao corpo, o espírito deve ser adornado com vários fios de contas negras (Miller, 2013).

Outros objetos, durante a sua produção incorporam certas dimensões subjetivas dos seus fazedores, emulando em sua forma material intencionalidades imateriais, podendo ser comparados a filhos, pois são produto da entrada de substâncias e sentimentos de seus produtores/ genitores, constituindo assim, um tipo de extensão dos seus corpos. Lagrou (2013), por exemplo, sugere que os desenhos e objetos Kaxinawa são uma memória cristalizada das pessoas que os confeccionaram e também uma rede que conecta os indivíduos a outros humanos e não humanos. Segundo Santos Granero (op.cit) isto envolve um processo duplo de objetivação/subjetivação, pois ao transformar a matéria prima por meio de seus sentimentos, destreza e intencionalidade, o fabricante cria um objeto que é ao mesmo tempo um sujeito.

Hill (2013) chama de "materialização do oculto" um processo de objetivação de subjetividades sobrenaturais. Entre os povos amazônicos a fabricação de objetos rituais é o meio de materializar subjetividades sobrenaturais, o que é perceptível, sobretudo, nos contextos xamanísticos onde certas relações subjetivas, como medo da morte, doenças, conflitos, etc, são transformadas em objetos. Normalmente a estes objetos é atribuída uma grande agência e poderes extraordinários, como a 
autotransformação (Santos Granero, 2013: 36-37). Entre os Waujá, flautas, máscaras, tambores, etc, fabricados por especialistas rituais para fins curativos, corporificam seres patogênicos chamados de apapaatais. Estes objetos subjetivados são produzidos com materiais cujas características, como dureza e durabilidade, resultam em graus diferentes de poder e agentividade (Neto, 2013).

Da mesma forma que os objetos podem atuar como pessoas, a sua vida também segue o mesmo ritmo da vida de uma pessoa. Assim, na Amazônia, como as pessoas e outros seres vivos, o objeto possui o seu próprio processo de vida, que acaba com o envelhecimento e destruição. A velocidade deste processo pode variar, contudo, um objeto não sobreviverá à morte do seu dono, já que quando o corpo se desintegra e a alma tem de partir, tudo o que lembra o seu dono e que pode provocar o seu apego precisa se dissolver ou ser destruído (Lagrou, 2007:53).

Conforme aponta Lagrou (2007: 53), isto contrasta com o que é visto na Etnografia da Melanésia, onde os objetos, como os braceletes e colares do Kula, sobrevivem à morte biológica dos seus donos de modo a manter viva a sua lembrança, se tornando, assim, uma extensão do seu corpo. O objeto se torna uma entidade distribuída, ampliando o seu campo de atuação em termos de tempo e espaço. A canoa Kula, por exemplo, continuava ligada ao seu dono, mesmo após a sua troca, representando assim, toda uma rede de interações pela qual passou ao longo de sua vida enquanto objeto (Lagrou, op.cit.; Munn, 1977). Na Amazônia, por outro lado, o objeto, ao invés de incorporar a lembrança do seu produtor ou dono de modo a possibilitar que ele continue vivendo entre os vivos através das suas extensões, precisa ser desfeito para ajudar mortos e vivos a aceitarem a transformação que a morte significa (Lagrou, 2007: 54).

Por serem considerados extensões corporais dos seus donos, os objetos devem ser destruídos após a morte deles, pois como uma parte não sepultada do morto, a alma pode permanecer ao seu redor a fim de perseguir os vivos. Turner (2013: 208), por exemplo, registrou que entre os Kayapó, do Brasil central, os pertences dos mortos são destruídos deliberadamente ou "mortos magicamente", com o propósito de evitar o uso deles pelos parentes que continuam vivos, o que poderia favorecer o retorno da "sombra" do morto ao mundo dos vivos.

A prática de destruir os bens dos mortos, entretanto, não é generalizada e não se aplica a todos os objetos. Nas sociedades amazônicas de regimes de objetos 
mais opulentos certos objetos não são destruídos na ocasião da morte dos seus donos (Santos Granero, 2013.), mas podem ser transferidos através das gerações, como ocorre com as flautas de madeira Waujá, uma das poucas categorias de objetos rituais que não são destruídas (Neto, 2013: 201).

Certos objetos considerados muito poderosos, em algumas ocasiões, necessitam ser desubjetivados de modo a torná-los inanimados. Isto pode ocorrer antes da transferência de objetos pessoais ou rituais a terceiros, quando tais objetos são desubjetivados para impedir que prejudiquem o seu receptor ou mesmo que sejam usados pelo receptor para prejudicar o antigo dono (Santos granero, op.cit.). Outros objetos podem ser fabricados prevenindo que a sua subjetividade se manifeste, como no caso das máscaras Waujá, que quando feitas para venda não possuem olhos, boca dentes, etc, o que impede que a sua subjetividade se manifeste (Neto, 2008a).

Em outros casos, para desubjetivar certos objetos, eles são retirados de circulação pública, como as redes dos bebês Urarina que são guardadas cuidadosamente até que apodreçam (Walker, 2013). Objetos altamente subjetivos são mutilados antes de serem retirados de circulação, para que sua subjetividade seja enfraquecida de modo a torná-los menos perigosos, como no caso das máscaras cerimoniais Wajana ${ }^{12}$, cujas plumas são retiradas antes de serem guardadas debaixo do teto da casa cerimonial até que apodreçam (Van Velthem, 2003; Santos Granero, op.cit.).

Diante de contextos tão complexos em que objetos são concebidos como pessoas, e atuam como elas, tendo, inclusive, um ciclo de vida semelhante, entender as peculiaridades que estruturam a fabricação, circulação e descarte dos objetos pode ser enriquecedor para o estudo de certos objetos encontrados em contextos arqueológicos, o que é válido, principalmente, para a categoria de objeto sobre a qual esta dissertação versa, as tangas cerâmicas, que como veremos no capítulo 3, na maioria das vezes, são provenientes de contextos funerários, embora certas características sugiram que não eram fabricadas exclusivamente para o acompanhamento funerário.

\footnotetext{
${ }^{12}$ De acordo com Van Velthem (2013: 139), professores Wayana da terra indígena Rio Paru d'Este, a fim de normatizar a escrita da língua, deliberam que o etnônimo deve ser grafado como Wajana, e não mais como Wayna ou Waiana.
} 


\subsection{Anatomias artefatuais: corporalidade na Amazônia indígena}

No mundo ameríndio alguns objetos são tratados como corpos e corpos são tratados como artefatos (Lagrou, 2007, 2009; Van Velthem, 2009). Neste sentido, é bem comum que cópias sejam consideradas da mesma natureza que o seu protótipo, pois são produzidas por meio das mesmas técnicas (Lagrou, 2009:39). Como já comentado, o caráter de pessoa ou corpo que é conferido ao objeto é tanto que eles possuem um ciclo de vida muito semelhante aos das pessoas (Lagrou, op.cit. ; Santos Granero, op.cit.; Van Velthem, op.cit.;)

Tanto Van Velthem $(2003,2008)$ quanto Lagrou $(2007,2009)$ apontam para o papel da corporalidade entre os ameríndios ao destacarem a produção de humanos com as mesmas técnicas de produção dos artefatos e a produção de artefatos com as mesmas técnicas de produzir humano em certas ontologias, como as Wajana e Kaxinawa. Se entre os Wajana as pessoas têm um caráter artefatual que é conferido pela decoração dos corpos com as mesmas técnicas que são usadas para decorar os artefatos, entre os Kaxinawa os objetos são produzidos com as mesmas técnicas que as pessoas são produzidas ${ }^{13}$.

Se por um lado é inquestionável o caráter de pessoa que os objetos possuem entre os ameríndios, por outro, não se pode negar o papel que objetos possuem na socialização do corpo e da pessoa (por exemplo, Seeger, 1980; Lagrou, op.cit; Seeger et al, 1979). A noção de corporalidade está dentro de uma preocupação maior que é a definição e construção da pessoa pela sociedade (Seeger et al, 1979: 3-4). A produção física de indivíduos se insere em um contexto voltado para a produção social de pessoas.

Nisto, a decoração que (des)cobre ou, por outro lado, altera a forma dos corpos tem um papel significativo. Isto está associado ao fato de que a superfície do corpo não é apenas o limite do indivíduo como uma entidade biológica e psicológica, mas a fronteira do eu social também. O corpo é o lugar pelo qual as pessoas são socializadas, isto é, integradas, ao longo de suas vidas, nas sociedades às quais

\footnotetext{
${ }^{13}$ Neste caso, o exemplo mais claro é aquele de um banco confeccionado com a madeira da samaúma e usado pelas crianças para descansar durante as intervenções rituais. Este banco é produzido pelas mesmas técnicas que produziram a estrutura da criança no ventre da mãe e recebe a mesma decoração que a pele da criança receberá após um rito de passagem (Lagrou, 2007). Para os Kaxinawa, a árvore da samaúma é o protótipo do corpo humano e isto se reflete na fabricação do banco, que é esculpido das raízes tubulures desta árvore à imagem da criança, com duas pernas e um buraco no meio. Este banco é pintado com grafismos grossos, ou seja, mais permeáveis, que visam passar o conhecimento e qualidades da samaúma para a criança.
} 
pertencem. Assim, a superfície do corpo, como a fronteira comum da sociedade, do eu social e da pessoa psico-biológica se torna o palco simbólico sobre o qual o drama de socialização é decretado, e a ornamentação corporal se torna a linguagem através da qual ela se expressa (Turner, 1980:112). Deste modo, a decoração é a projeção gráfica de uma realidade de outra ordem, no cenário social, da qual a pessoa também participa, uma pele social.

O conceito de pele social, inicialmente cunhado por Turner (1980) e depois empregado para entender ornamentação corporal, também faz alusão à comunicabilidade de outras superfícies ou corpos, no caso deste trabalho, de corpos cerâmicos. Lau (2010; 2013), por exemplo, utilizou este conceito para mostrar que diferentes procedimentos técnicos, que tornavam a superfície das coisas (artefatos) semelhantes, estavam relacionados à confecção de mundos e estéticas associados aos chefes da cultura Recuay. Tais superfícies trabalhadas marcavam corpos com capacidades e papéis sociais, expressando relações entre pessoas, lugares e coisas, exteriorizando em cada um, tipos especiais de corpos interativos, sociais.

Se por um lado a construção social do corpo está voltada para a socialização da pessoa, por outro lado, para Viveiros de Castro (2002: 388), está relacionada à ideia de corpo enquanto lugar da alteridade, pois ao passo que uniria seres do mesmo tipo, também os distinguiria de outros seres. Este autor argumenta que o principal objetivo da construção social do corpo é o de particularizar um corpo demasiadamente genérico tornando ele distinto de outros grupos humanos e de outras espécies. Neste sentido, o corpo é o principal instrumento para expressão do sujeito e ao mesmo tempo, aquilo que se mostra ao outro. Assim, a máxima objetivação social dos corpos, expressa em sua decoração e exibição, ocorreria em contextos cerimoniais, coincidindo com a sua animalização, quando os corpos dos participantes são cobertos com plumas, peles, cores, grafismos, máscaras, assim como outras partes emblemáticas dos corpos animais (Viveiros e Castro, 2002: 388389).

Santos Granero (2012: 21) sugere que as diferenças corporais entre as formas de vida não são absolutas já que o corpo é um amálgama de seres, e com isto, as diferenças seriam graduais. Os corpos seriam compostos a partir de uma combinação de afetos e capacidades provenientes de uma miríade de seres, entre os quais, os objetos, o que está de acordo com o que é visto nas ontologias 
amazônicas onde a ênfase na incorporação, a "canibalização" do outro é um traço indispensável para a construção do "eu" (retomaremos este aspecto adiante).

Para Santos Granero (2013: 41), as ontologias amazônicas em que a pessoa é constituída a partir de uma complexa relação entre distintas formas de vida são "ontologias construtivistas". Este construtivismo amazônico concebe todos os seres vivos como entidades compostas, feitas de corpos e partes de corpos de uma gama de formas de vida, entre as quais os artefatos se destacam. Tal ideia é proeminente, sobretudo, nas narrativas míticas sobre a criação do mundo e das diferentes formas de vida que o habitam que destacam que nos tempos primordiais só existiam as pessoas e os seus artefatos ou, dependendo, somente os artefatos. Estes objetos são concebidos como as "células" a partir das quais os corpos das pessoas e dos deuses foram criados.

A contribuição dos objetos, não só em tempos míticos ou primordiais, mas ainda hoje, para a fabricação da pessoa é paradigmática. Na Amazônia há uma série de exemplos que mostram a importância dos objetos para a composição corporal dos seres vivos. Walker (2012), por exemplo, mostra que entre os Urarina, povo da Amazônia peruana, as redes dos bebês e os chocalhos destas redes formam, protegem e fortalecem o corpo dos bebês aos quais pertencem. Os componentes dos chocalhos destas redes são selecionados criteriosamente pelos pais e elaborados com partes de animais e outros objetos, a fim de incutir nos bebês qualidades animais ou artefatuais altamente valorizadas.

Deste modo, nas ontologias ameríndias os objetos são componentes importantes de todas as formas de vida, pois foram incorporados por meio de processos primordiais de criação ou por meio das técnicas cerimoniais de construção do corpo. Aqui, é generalizada a ideia de que os objetos eram pessoas ou partes anatômicas de pessoas que foram transformadas posteriormente em outros seres, o que sugere que as pessoas e os objetos compartilham do mesmo princípio simbólico de fabricação (Santos Granero, op.cit.).

A importância de certos objetos se desdobra nas noções de pessoa e de corporalidade. Entre os ameríndios os objetos integram um importante papel na constituição de corpos e pessoas, como se vê, por exemplo, nos adornos corporais, que são incorporados à pessoa ao longo do seu processo de vida, configurando corpos socialmente eficazes (Seeger, 1980) e mesmo, como já foi comentado, se 
integrando aos corpos de tal modo que se tornam uma parte constituinte da pessoa (Miller, 2013).

\subsubsection{A transformabilidade dos corpos e das formas}

Estudos realizados entre diversos povos das terras baixas da América do Sul, sobretudo, na Amazônia, reconhecem que a transformabilidade dos corpos e das formas é um aspecto estruturante das cosmovisões e ontologias indígenas (Lagrou, 2007, 2011; Lagrou e Severi, 2013; Viveiros de Castro, 2002).

A importância do fenômeno da transformabilidade foi destacada, principalmente, com o reconhecimento do caráter perspectivista das ontologias ameríndias, e subjacente a isto, o pressuposto de que a humanidade é um atributo compartilhado por todos os seres animados, trazendo importantes implicações para o estudo das imagens ameríndias (Lagrou, 2011; Taylor e Viveiros de Castro, 2006).

De acordo com a cosmovisão perspectivista, o modo como os seres humanos veem os animais e outras subjetividades que povoam o universo difere da forma como estes seres veem os humanos e veem a si mesmos. Deste modo, os animais se veem como humanos enquanto os humanos veem os animais como caça; os humanos se veem como humanos e são vistos por determinados espíritos como caça (Viveiros de castro, 2002). Diante disto, o corpo humano não ocupa um lugar único e estável no esquema cósmico, pois sua forma é inteiramente relativa à perspectiva de outrem: o humano ou o não humano está no olhar do outro em vez de ser o atributo essencial de uma classe de seres (Tayor e Viveiros de Castro, op.cit.). Assim, o referencial comum para todas as espécies da natureza, não é o homem enquanto espécie, mas a humanidade enquanto condição (Descola, 1986:120 apud Viveiros de Castro: 356).

Esta concepção subjaz à ideia de que a forma que cada espécie manifesta é uma roupagem que esconde uma forma humana interna visível apenas aos seres da própria espécie, ou seres transespecíficos, como os xamãs. Deste modo, todas as espécies são caracterizadas por um espírito antropomorfo e por uma aparência corporal variável, característica de cada espécie, que não é fixa, mas sim considerada uma roupa que pode ser trocada e descartada. Aliás, a noção de roupa está estreitamente relacionada à metamorfose, processo generalizado no "mundo 
altamente transformacional" dos ameríndios amazônicos (Viveiros de castro, 2002: 351).

Decorrente da noção de perspectivismo é a abordagem de Lagrou (2007, 2011, 2013) para a arte gráfica ameríndia, focando, sobretudo, nas formas de percepção e figuração no mundo ameríndio. Esta autora propôs inicialmente que na arte gráfica kaxinawa um desenho "abstrato" opera a passagem entre o visível e o invisível (Lagrou 2007), propondo posteriormente que esta característica dos grafismos pode ser compreendida enquanto uma linguagem pan-amazônica (Lagrou 2011, 2013). Deste modo, os grafismos e imagens ameríndios poderiam ser compreendidos como instrumentos perceptivos que demandam operações cognitivas específicas estruturadas no âmbito de uma ontologia na qual a transformação dos corpos e formas é um aspecto central. Nisto, certos procedimentos formais, inclusive, podem ser considerados como técnicas perspectivistas, ou seja, são procedimentos que permitem ao espectador mudar de ponto de vista, o que melhor detalharemos no capítulo 4 .

Ao mesmo tempo se reconhece que os sistemas estéticos ameríndios também são caracterizados pela captura e controle de agências inimigas e predatórias, onde a agência do outro nunca é aniquilada, mas sempre integrada através de uma técnica estética que, diante do potencial perigo da predação, visa o controle da manifestação de sua forma (Lagrou, 2007, 2012).

A lógica da predação e da incorporação é também um traço constituinte das ontologias amazônicas, as quais incorporam aspectos integrantes da alteridade, seja inimigos ou outros seres. Com isto, na Amazônia ameríndia, o processo de constituição do "eu" pelo "outro" implica também em uma maneira bastante específica de se relacionar com o outro, onde o tornar-se sujeito é ao mesmo tempo tornar-se parcialmente o outro, decorrendo disto um significativo aumento da subjetividade do "eu" (Lagrou, 2007: 61-62).

Nas terras baixas sul-americanas de uma forma mais ampla, a produção estética é o resultado da incorporação de elementos provenientes de uma fonte externa, geralmente atribuída ao mundo dos inimigos ou de outros seres, de onde provêm os nomes dos motivos gráficos, mitos de aprendizado dos grafismos, ornamentos e demais artefatos, bem como de suas técnicas de execução (Lagrou, op.cit; ; Miller, 2007, 2012). Este aspecto foi amplamente debatido por Lagrou (2011) 
como um dos possíveis traços constituintes de uma "arte das sociedades contra o Estado", nos termos de Pierre Clastres $(2003,2004)$ de que as sociedades ameríndias das terras-baixas não apenas são fundadas sob a lei do igualitarismo, mas que também adquirem o conhecimento sócio-cosmológico no exterior da própria sociedade.

Para os kaxinawa, por exemplo, determinados motivos estruturados a partir da "grega", além de receberem nomes técnicos relacionados a animais e plantas, são também nomeados de nawan kene, isto é, desenho do estrangeiro/ inimigo, nome que designa, inclusive, a escrita dos brancos. Estes desenhos de inimigos fazem parte do repertório de desenhos próprios, os Kene Kuin, e são aplicados sobre o rosto, compondo uma rede de linhas. Também para os Kaxinawa, os motivos que compõem os grafismos podem ter a sua origem nos predadores, como a anaconda, dunuã, e a onça, inu. Com isto, a estética consiste na integração e dosagem de agências inimigas e predatórias (Lagrou, op.cit.).

Deste modo, para os kaxinawa a relação entre grafismos e suporte é uma relação transformativa, pois os grafismos inscrevem a potência que é adquirida externamente à sociedade nos corpos sobre os quais estão aderidos. Os motivos gráficos que cobrem os corpos são adquiridos no exterior, no mundo dos inimigos ou de outros seres e visam produzir novos corpos, mas precisam ser reestruturados esteticamente, pois devido à agência dos seus donos invisíveis são capazes de impor novas formas aos corpos sobre os quais serão pintados. Percebe-se, assim, que a estética é uma técnica que visa uma bricolagem de corpos, onde a alteridade é transformada, mas sua agência jamais é totalmente eliminada (Lagrou, op.cit.).

Analogamente, mas especificamente no campo dos adornos corporais, Miller (2007, 2012) destaca que entre os Mamaindê, os adornos corporais são o resultado de um processo de apropriação pelos xamãs de coisas feitas por "outros", isto é, os espíritos dos mortos ou dos espíritos considerados donos dos animais e plantas. Por um lado, o xamã adquire adornos feitos pelos espíritos dos mortos e estes se constituem a base do seu poder. Estes adornos possuem a agência dos espíritos dos mortos, os seus criadores, e por esta razão é que são poderosos. Por outro lado, a confecção de adornos corporais feitos de materiais como folhas de buriti e madrepérola, utilizados em diversos rituais, está sujeita ao estabelecimento de 
relações entre os espíritos considerados como donos do buriti e das conchas, a partir das quais os adornos são feitos.

A aquisição de adornos provenientes destas duas classes de espíritos pode se dar também quando o xamã olha os adornos deles. Por exemplo, a origem do cocar de penas de tucano, usado em rituais de puberdade feminina, é associada a um evento no qual um xamã que estava na beira de um rio viu o povo da água usando um cocar feito de penas de tucano vermelhas e amarelas e copiou o adorno usado por eles, ensinando aos Mamaindê como fazê- lo (Miller, 2007: 108).

Os exemplos citados mostram que a produção estética está relacionada à captura e incorporação de aspectos integrantes da alteridade. Neste sentido, a produção de objetos e imagens pode, por um lado, presentificar e tornar visíveis seres, e pode, por outro lado, fomentar a (re)produção de elementos sobrenaturais que jamais perdem a sua agência.

O controle destas agências, sobretudo, das agências predatórias, que são integradas é um aspecto que deve ser considerado. Para se ter uma ideia, os artefatos Wajana possuem os seus protótipos nas anatomias de animais, de seres arquetípicos ou de sobrenaturais de onde adquirem a sua visibilidade e capacidade de agir. No entanto, são entendidos como corpos parcelados, pois sofreram um processo de desmembramento, ou a supressão das suas características originais, descontroladas e predatórias. O tipiti, por exemplo, possui o seu protótipo na serpente/ larva Kutupxi e compartilha com ela a capacidade de constringir, capacidade necessária que visa a extração do sumo da mandioca para a produção da massa de fazer o beiju, no entanto, é um corpo/ artefato parcelado, já que não possui cabeça nem rabo, para não se tornar o ser independente que devora humanos (Van Velthem, 2003, 2009).

\subsubsection{Imagens fractais, corpos compósitos}

Na Amazônia, semelhantemente ao que ocorre na Melanésia a pessoa é concebida como um ser divisível (Lagrou, 2007), em oposição a um ser indivisível, um indivíduo. Na Melanésia este fenômeno foi denominado de divíduo (Strathern, 2006) ou pessoa fractal (Wagner, 1991) sendo caracterizado pela objetificação das relações de pessoas e grupos de pessoas através da troca de valores e bens. $O$ 
conceito de divíduo diz respeito à divisibilidade da pessoa, às partes da pessoa que podem circular entre outras pessoas, constituindo, assim, novos seres e objetos. $O$ conceito de pessoa fractal, por sua vez, implica também na constituição relacional da pessoa, onde a existência de uma entidade abrange relações integralmente implicadas, sendo que cada parte constituinte abrange informações sobre o todo.

No âmbito das expressões artísticas, Gell (1998) sugere, para o contexto da Melanésia, que muitas imagens são fractais, e contêm em si diversas versões, em menor escala, delas mesmas, de modo que cada uma dessas versões é a presentificação do que pode ser extraído da própria imagem. De acordo com este autor, tais imagens poderiam ser tomadas como exemplos de uma espécie de "figura de linguagem" que expressa a noção de pluralidade singular e singularidade plural. Assim, estas imagens poderiam se compreendidas a partir da noção de que cada pessoa é "múltipla" no sentido de ser precipitada de uma multiplicidade de relações genealógicas, cada uma das quais é instanciada nela e, inversamente, a pessoa é um agregado de pessoas (Gell, 1998:140).

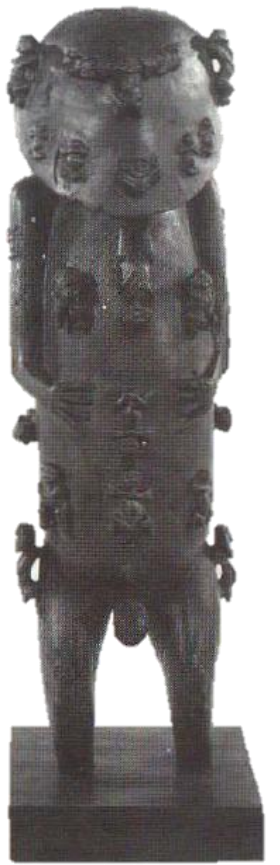

Figura 5. Estatueta fractal A'a de Rurutu. British Museum, Londres. Fonte: Gell: 1998: 138.

Certos objetos registrados na etnografia Melanésia seriam exemplos paradigmáticos deste tipo de imagem. A estatueta que representa o deus A'a, por exemplo, é constituída por diversas outras figuras em escala menor que também reconstituem a forma desta deidade, ou seja, esta estrutura fractal é caracterizada pela autosimilaridade em escalas distintas de maximização ou minimização. Ao mesmo tempo esta figura é também uma espécie de caixa ou arca que mantinha originalmente outras figuras de deuses em seu interior (Gell, 1998: 137).

Assim, neste caso específico, a imagem representa um deus singular como um conjunto de relações entre homúnculos, evidenciando a dialética entre um e muitos, entre o que está fora e o que está dentro. Os componentes replicados em menor escala aludem tanto à personitude enquanto um agregado de relações externas quanto à possessão de uma pessoa interior, caracterizada neste caso, por um conjunto de homúnculos, de modo que o A'a não pode ser individualizado. 
$\mathrm{Na}$ Amazônia, do mesmo modo, a pessoa é concebida como um ser relacional, processual e divisível, já que as partes que são incorporadas por outros continuam a manter relações com a pessoa que as emitiu paralelamente em que colaboram na produção e constituição de novos seres (Lagrou, 2007: 26). No entanto, a constituição da pessoa amazônica possui uma lógica diferente à da divisão; aqui a ênfase sobre a incorporação do outro recai sobre o acúmulo.

As relações no mundo amazônico ameríndio são estruturadas com base na ontologia da predação, conforme já comentado anteriormente, de modo que por meio destas relações as pessoas, ao longo da vida, incorporam partes de outras pessoas e seres (Lagrou, op.cit.). Diante disto, a pessoa ameríndia pode ser compreendida como uma pessoa fractal, na medida em que implica em relações de incorporação do outro na constituição do "eu" em diferentes escalas que são sempre similares umas às outras (Santos Granero, 2013: 31).

Especificamente no âmbito da produção artística ameríndia isto resulta em objetos e imagens compósitos, constituídos por seres e partes anatômicas de seres (Lagrou, 2013; Santos Granero, op.cit:; Severi, 2013). No que diz respeito às expressões artísticas da Amazônia antiga estas relações de incorporação de seres e partes suas resultam em objetos e imagens híbridos. Neste caso, as imagens resultantes desta bricolagem de seres podem abranger figuras antropozoormorfas com traços anatômicos que podem ser compostos, por exemplo, por figuras serpentelíneas caracterizando os seus membros, como ocorre em certas urnas funerárias marajoara (Barreto, 2014; Roosevelt, 1991; Schaan, 1997) e também em muitos temas iconográficos que caracterizam a iconografia da cerâmica Guarita (Oliveira, 2016). O mesmo ocorre na iconografia das tangas cerâmicas, onde são recorrentes as imagens que aludem a partes corporais específicas, como por exemplo, faces, mas que são compostas por corpos de seres e de partes anatômicas de seres, sugerindo processos de transformação.

Fausto (2013) argumenta que nas iconografias e objetos rituais ameríndios há um modo bastante específico de figurar a transformação, onde o caráter transformacional dos seres e a ambiguidade das formas são indiciados pela multiplicação de referentes e pela mistura entre as formas animais e humanas.

(...) seu problema jamais foi a semelhança e a forma humana, mas o modo de representar a transformação, de transpor em imagens o fluxo transformacional que caracteriza os seres poderosos. A resposta a este problema não podia ser encontrada na reprodução a mais exata possível 
das formas naturais; mas, ao contrário, era preciso buscá-la na geração de imagens as mais complexas e paradoxais possíveis, nas quais as identidades estão encaixadas e os referentes são múltiplos (Fausto, 2013:328).

Fausto (2013), em uma comparação entre as máscaras rituais ameríndias da costa noroeste da América do Norte com aquelas da Amazônia, em particular, do Alto Xingu, demonstra que nestes dois contextos "animistas"14, as máscaras são marcadas pela capacidade de transformação e pela identidade múltipla de seres. No caso específico das máscaras do Alto Xingu, a referência múltipla é caracterizada por um tipo de figuração pouco antropomorfa, pela fusão de referências, pelo uso de grafismos e cores que se referem à presença simultânea dos seres.

Os princípios formais, empregados na confecção destas máscaras, mas generalizados nas iconografias ameríndias, dialogam amplamente com o conceito de pessoa compósita e múltipla amazônica. No mundo ameríndio, a figuração de seres extraordinários está intrinsicamente associada a este conceito, de modo que objetos rituais, construídos enquanto subjetividades poderosas, são seres múltiplos, capazes de transformação (Fausto, 2013: 324).

As ideias e conceitos comentados até aqui trazem importantes implicações para o estudo dos objetos e imagens produzidos no mundo ameríndio, onde estes são sempre fabricados integrando-se componentes e agências de seres diversos. No caso específico dos objetos provenientes de contextos arqueológicos os desdobramentos vão além da identificação de seus componentes, podendo ser críticos para a reflexão sobre as suas formas específicas de agentividade.

No próximo capítulo nos concentraremos especificamente nos contextos de deposição das tangas, bem como em alguns aspectos de sua variabilidade, de modo a refletir acerca da sua agentividade.

\footnotetext{
14 Optamos por destacar o termo com aspas para enfatizar que Fausto (2013) faz uma reapropriação contemporânea do termo original. É importante destacar que, originalmente, o termo foi proposto por Edward B. Tylor em seu livro Primitive Culture, publicado em 1871, para designar o "primeiro estágio" da evolução religiosa da humanidade. Por esta razão, durante décadas, o termo teve uma conotação perjorativa, sendo usado para desqualificar e esteriotipar populações.
} 


\section{CAPÍTULO 3}

\section{CORPOS DE BARRO E DE TINTA}

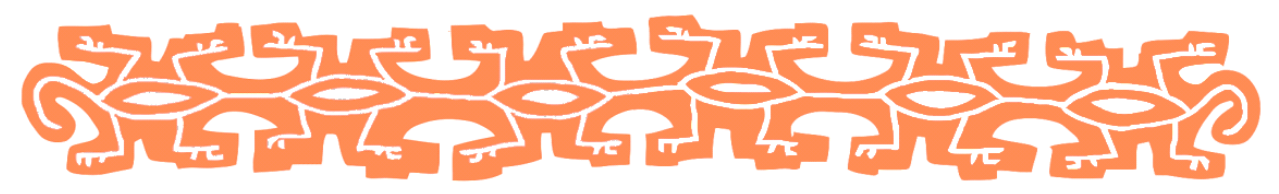

(...) em 1950, Peter Paul Hilbert, de uma das suas viagens ao Pacoval trouxe um ídolo feminino que, esse sim, ostenta uma legítima "tanga" marajoara, figurada em relevo e com ornamentação pintada (...) todo o ídolo, ao qual falta infelizmente a cabeça, é também ornamentado a capricho com desenhos incisos que talvez representem pinturas corporais ou tatuagens, exigidas possivelmente para a cerimônia especial em que a "tanga" se utilizava (Barata, 1968:102).

O trecho acima ilustra discussão antiga sobre o uso das tangas. Nele Frederico Barata usa uma possível representação de tanga no fragmento de estatueta (figura 6) para convencer o leitor de que as tangas eram usadas sobre a região pubiana ${ }^{15}$.

Hoje, no entanto, há poucas dúvidas de que estas peças eram usadas junto ao corpo, contudo, muitos aspectos relacionados ao seu uso e simbolismo são controversos.

Dentro disto, todo um conjunto de

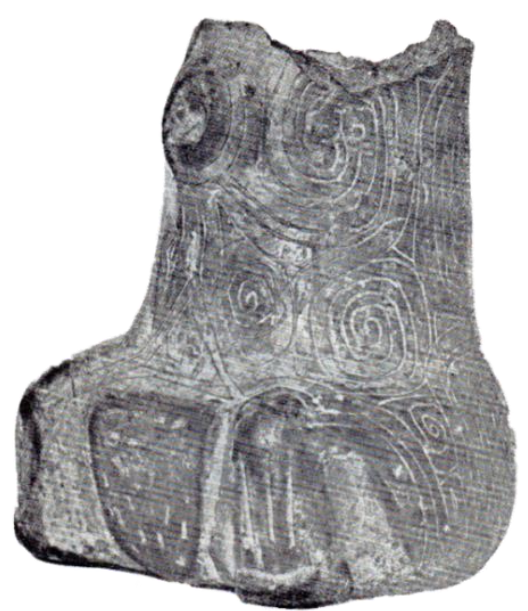

Figura 6. Estatueta marajoara com triangulo pubiano em relevo recolhida por Peter Paul Hilbert no teso do Pacoval. Fonte: Barata, 1968:39.

${ }^{15} \mathrm{O}$ mesmo tipo de triângulo modelado é também visto em certas urnas funerárias, aparecendo sempre coberto por tracejados, o que para autores como Roosevelt (1991) é uma forma de representar pelos. Deste modo, não há como assegurar se o triângulo é a representação de uma tanga ou de uma genitália, pode inclusive, ser os dois ao mesmo tempo. 
hipóteses, em termos bastante funcionalistas, foi elaborado, sobretudo, no tocante à diferença entre tangas monocromáticas ${ }^{16}$ e aquelas com grafismos. Para se ter uma ideia, sugeriu-se que os dois tipos poderiam ter estado associados a diferentes atividades, sendo as monocromáticas usadas no cotidiano e as com grafismos em rituais (Evans e Meggers, op.cit.), ou ainda, que tivessem sido usadas por mulheres de faixas etárias diferenciadas (Schaan, 2003).

Nos capítulos anteriores apresentamos um panorama geral sobre o modo como a iconografia da cerâmica marajoara tem sido abordada e pensada dentro de certos contextos propostos. Apresentamos também os eixos teóricos que nortearão a discussão sobre a iconografia das tangas neste trabalho, centrados, sobretudo, nas teorias formuladas no âmbito das expressões artísticas das sociedades ameríndias a respeito da construção dos corpos e formas de agentividades conferidas a eles.

No presente capítulo pretendemos apresentar os contextos de deposição das tangas e algumas características referentes à sua variabilidade para, enfim, propor que algumas destas características podem ter estado relacionadas a diferentes modos de agentividade destes itens.

\subsection{Os contextos das tangas}

Apesar das significativas quantidades de tangas existentes em museus, a maior parte delas não é proveniente de escavações sistemáticas. Os documentos de entrada das peças nas instituições possuem poucas informações, sendo que os critérios usados para documentar a sua entrada, muitas vezes, não distingue uma peça de outra ${ }^{17}$. Com isto, são poucos os casos em que se pode recuperar a proveniência de uma ou outra peça, e, mais raros ainda, são os casos em que podemos recuperar os contextos específicos nos quais uma ou outra peça foi

\footnotetext{
${ }^{16}$ Neste trabalho, para nos referir aos dois tipos conhecidos de tangas usaremos os termos "monocromática" para se referir às tangas lisas que não apresentam grafismos em sua superfície e "com grafismos" para aquelas cuja superfície foi elaborada com desenhos. Tentamos com isto evitar termos contraditórios usados para registrar estas peças, como por exemplo, decoradas e não decoradas, que opõe as duas como se uma fosse decorada e a outra não, quando na verdade ambas são decoradas por técnicas de pintura diferentes.

${ }^{17}$ No livro usado para documentar a entrada das peças no Museu Nacional nas últimas três décadas do século XIX, por exemplo, o único registro referente às tangas, registradas como babals, apenas relata a entrada de tangas e mais uma porção de objetos, sem especificar quais as tangas, sua procedência e matérias associados.
} 
encontrada. Deste modo, com base nos registros de escavações fizemos um levantamento para entender um pouco mais sobre os seus possíveis contextos de uso e descarte.

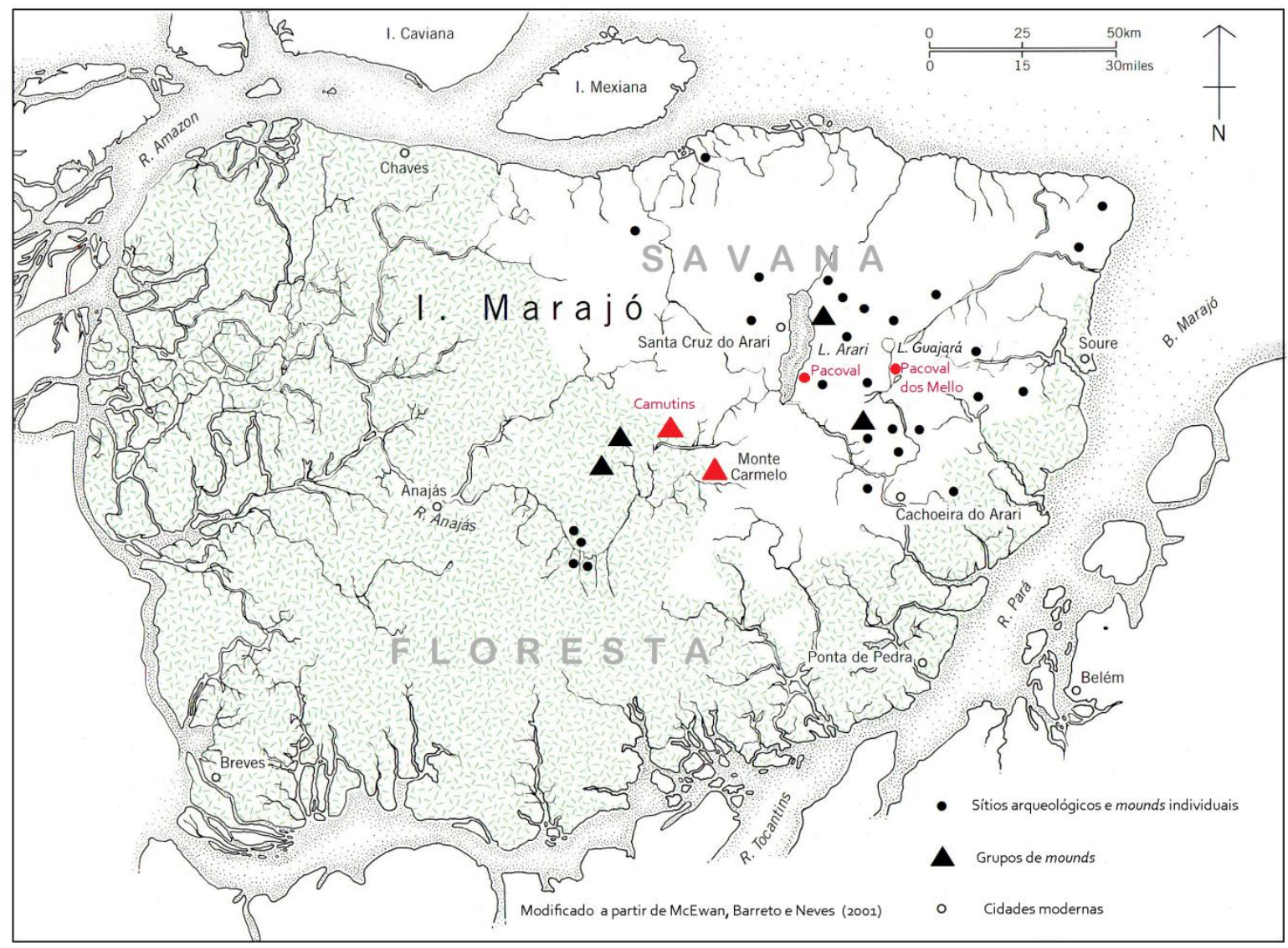

Figura 7. Mapa sítios da fase marajoara. Modificado a partir de McEwan at al, 2001.

Há, na bibliografia sobre as explorações aos tesos, um grande número de relatos registrando a retirada de tangas do interior de urnas funerárias, mas são poucos aqueles que detalham todo o contexto. Desmond Holdridge, por exemplo, escavou no teso Guajará (M-1), no Monte Carmelo, uma grande urna Joanes Pintado que continha em seu interior um enterro secundário, fragmentos variados e fragmentos de tanga cujo tipo não pudemos determinar (Meggers e Evans, 1957:308-309). Relatos como este abundam, mas só mostram que muitas tangas foram encontradas em sepultamentos. Com intuito de verificar as diferentes variantes destes contextos funerários relacionados com as tangas fizemos um levantamento com base nas descrições dos sepultamentos registrados, em diferentes sítios. 
Em fevereiro de 1915, representando o University Museum de Filadélfia, Farabee escavou em alguns tesos do conjunto conhecido como Fortaleza, na região do rio Goiapi. Na escavação do teso número 7 , deste conjunto, Farabee relata ter encontrado sepultamentos agrupados e que era possível em um espaço de 15 metros quadrados, por exemplo, encontrar 50 vasilhas, e outros 15 metros sem nada. Em um destes agrupamentos que escavou, em um espaço de 1,20 metros por $60 \mathrm{~cm}$, foram escavadas 7 vasilhas pertencentes a 4 enterros diferentes. Com base nos sepultamentos escavados, ele afirma haver dois tipos de sepultamentos, a dizer, sepultamento secundário e cremação. Entre os objetos encontrados com as urnas funerárias, em alguns casos, havia uma tanga dentro delas, mas era mais comum que as tangas tivessem sido colocadas, no exterior, junto com pratos e tigelas.

Farabee deixou um caderno de notas onde registrou mais de trezentos exemplares retirados das nove trincheiras escavadas no teso 7 de Fortaleza, indicando as posições relativas em que foram encontrados (Palmatary, 1950: 275). Entretanto, não há descrição textual de nenhum deles. Apesar de ter registrado várias notas em seu caderno de campo, os resultados das escavações jamais foram publicados, por isto só tivemos acesso às anotações publicadas por Palmatary (1950). Entre as notas publicadas, a única referente a uma tanga escavada diz respeito ao corte 4 de sua escavação no teso referido. A nota registra uma urna funerária com uma tanga em seu interior partida em três pedaços. ${ }^{18}$

Farabee posteriormente, entre novembro e dezembro de 1915, escavou no teso Belém, do conjunto Os Camutins. O registro publicado por Palmatary desta escavação descreve três cortes realizados naquele teso. Farabee relata que iniciou o corte 1 em um local próximo à extremidade sul do teso. Ali encontrou tantos potes juntos que era impossível cavar sem esbarrar em outro. Relata ainda que em um espaço de 1,8 metros quadrados escavou seis grandes urnas e três pequenas. Ali, duas tangas foram encontradas em urnas, sendo que uma estava no interior de uma grande urna pintada que jazia a 1,5 metros de profundidade, contudo, estas duas tangas não foram descritas, assim não podemos distinguir aquelas com grafismos das monocromáticas. Nas anotações do corte 2, que foi realizado próximo ao centro do topo do teso, há as seguintes notas: duas tangas e ossos foram escavados no

\footnotetext{
${ }^{18}$ Palmatary (1950:275) registra a seguinte nota : No. 23, top above the surface and gone. Inside was a tanga in three pieces in different places, broken purposely before placing inside (Palmatary, 1950:275).
} 
interior de uma urna; uma grande urna pintada com uma tanga e ossos foram encontrados a cerca de 1,5 metros de profundidade; uma tanga no interior de uma grande urna simples quebrada com dois sepultamentos em seu interior. ${ }^{19}$

Em 1928 Antonio Mordini escavou o sítio Panellas (figura 8). Entre os 32 itens registrados nesta escavação ${ }^{20}$, documentou a ocorrência de duas tangas, conforme pode ser visto na ilustração a seguir. A primeira foi uma tanga monocromática (vermelha) que foi encontrada junto a uma urna antropomorfa quebrada, ricamente decorada com gravuras, com 85 centímetros de altura. Já a segunda foi uma tanga com grafismos, descrita como ricamente pintada, encontrada junto a uma grande urna antropomórfica quebrada, e decorada com gravuras, com 85 centímetros de altura. As notas não trazem maiores detalhes que possam ajudar a identificar o tipo das urnas, mas a ilustração e a descrição "decorada com gravuras" sugere uma urna do tipo Pacoval Inciso ou Arari inciso, que normalmente se apresentam na forma de um corpo humano. Também não há descrições sobre o conteúdo delas, com isto, não sabemos se havia ossos e outros acompanhamentos em seu interior.

Nas anotações publicadas por Palmatary (op.cit.) há também a observação de que estas tangas "provavelmente tinham sido presas às urnas". Em carta à Palmatary, Mordini escreve que essas duas tangas eram unicamente cerimoniais, já que eram maiores do que o normal e possuíam pouca curvatura para uso real, além disto, os orifícios das suas extremidades não possuíam marcas de desgaste (Palmatary, 1950:280). Contudo, não tivemos acesso a estas duas tangas para medi-las, de modo que pudéssemos comparar as suas dimensões às das demais peças da nossa amostra. ${ }^{21}$ De todo modo, esta observação é bastante curiosa, já que Heloísa Alberto Torres ${ }^{22}$ (1940: XIII) escreve que segundo os relatos dos antigos exploradores, dentro de urnas simples havia urnas do tipo Pacoval Inciso e, nestas, havia uma tanga amarrada com cordões.

\footnotetext{
${ }^{19}$ Seguem as transcrições das notas referentes às tangas, como registrado em Palmatary (1950:276). Corte 1: 59 a large pot at surface crushed into a thousand pieces by weight of earth which had fallen into its empty body... 66 cut away for burial, tanga inside ; ...107 large, painted, 5 deep, tanga Inside. Corte 2: 9 inverted over 8 which had two tangas and bones in it ; ... 12, small, round, I ' deep near 13, 14, 15; 16, large, painted, 5' deep, bones, tanga; 20, large, undecorated, broken, had two burials and tanga, not possible to get measurements of skulls, although broke jar to save skulls, bodies had been put in whole at same time.

${ }^{20}$ Palmatary (1950:278 280) publicou algumas de suas notas de campo.

${ }^{21}$ É provável que estas peças estejam entre as 27 que foram destruídas na casa de Mordini durante a segunda Guerra Mundial.

${ }_{22}$ Esta autora, no entanto, não fornece qualquer referência que possa ser consultada para se obter mais informações a este respeito.
} 


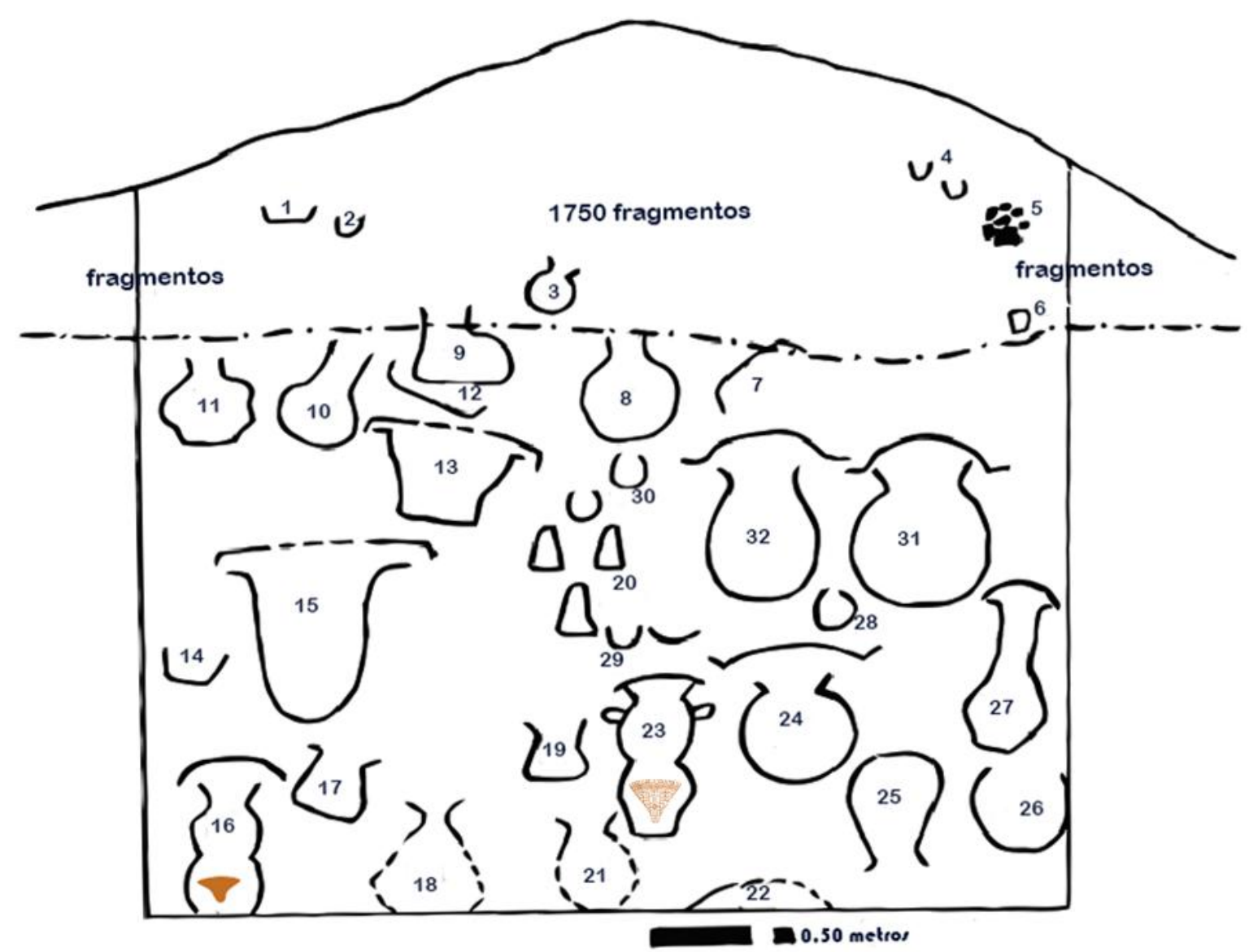

Figura 8. Esboço de perfil do teso Panellas feito por Mordini. Adaptado de Palmatary (1950).

Embora não tenhamos encontrado outros relatos sobre estas tangas "presas" em urnas funerárias, Hartt (1885) registra um relato de O. Derby bastante curioso. Orville Derby escavou em 1871, no teso Pacoval, uma tanga com grafismos associada a uma urna funerária do tipo Pacoval Inciso (figura 9). Segundo Hartt (1885: 34), a urna foi achada dentro de um pote muito grande, pesado, simples e arredondado, que a mantinha até o gargalo. No fundo desta urna do tipo Pacoval inciso havia ossos, e, segundo, Hartt (op.cit.), o espaço entre ela e o pote que a envolvia estava cheio de argila arenosa, e na frente da urna havia uma tanga quebrada. 


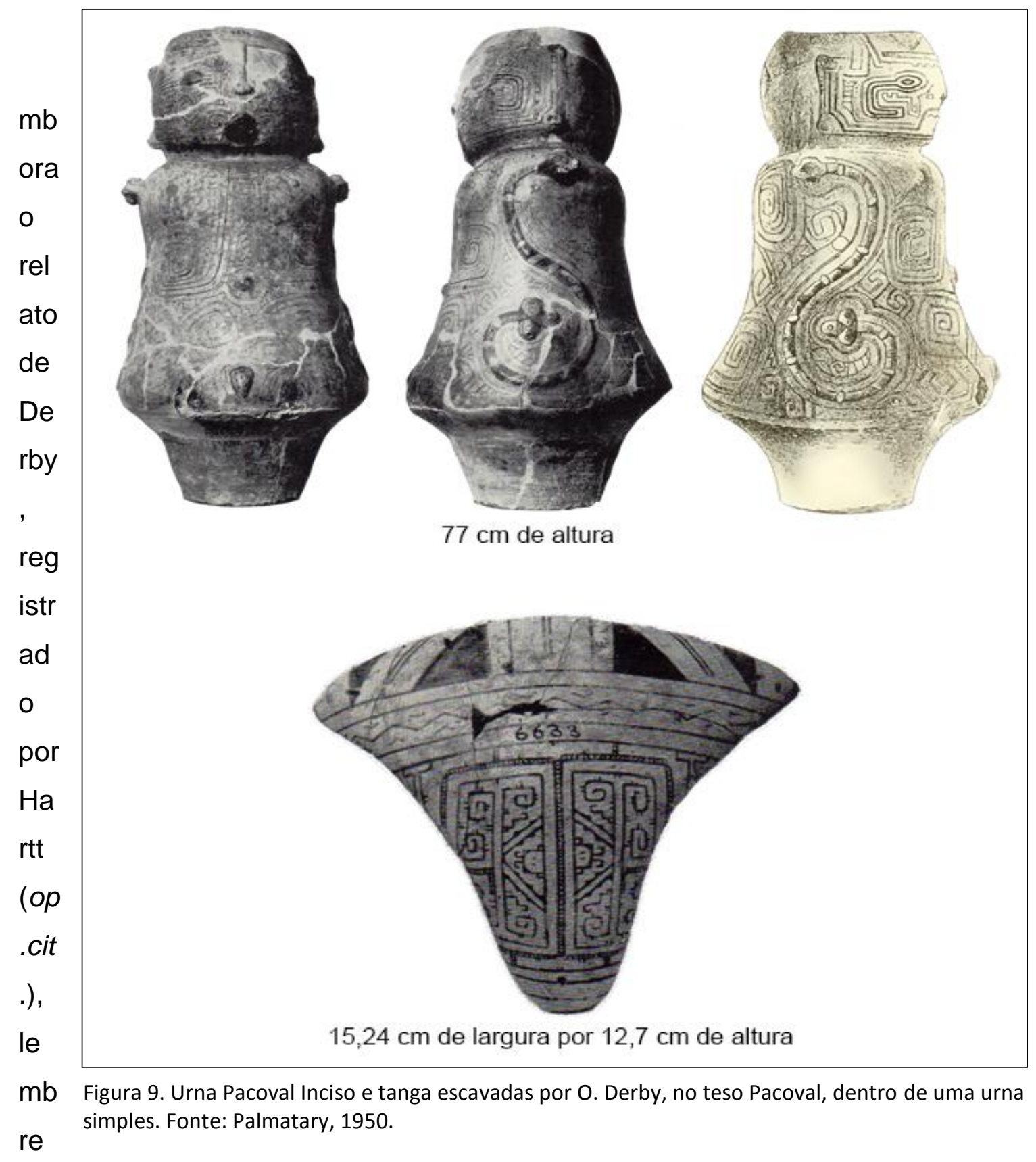

bastante 0 de Mordini e o de Heloísa Alberto Torres, não foi sugerido que a tanga estivesse atada à urna. Mordini relata que as duas tangas, que supunha terem sido amarradas às urnas, não possuíam marcas de desgaste em seus orifícios e que por tal razão devem ter sido exclusivamente para uso ritual, ou seja, para o ritual funerário. Conforme relata Hartt (1876: 25), as perfurações da tanga escavada por Derby, estão muito gastas na direção da margem superior, na vizinhança dos ângulos, o que pode ser visto na ilustração. É lógico que o fato da tanga citada apresentar marcas de desgaste em seus orifícios não exclui a possibilidade de que ela tenha sido atada à urna, já que segundo a descrição, ela estava na frente da 
urna Pacoval, separada do pote simples por uma camada de argila. Entretanto, não há outros relatos que confirmem isto, aliás, nas poucas escavações sistemáticas realizadas em sítios da fase marajoara jamais se encontrou algo que sugerisse isto.

Os detalhes mais bem registrados sobre as tangas em contextos funerários são provenientes das escavações de Meggers e Evans (op.cit.) nos tesos Guajará do conjunto Monte Carmelo e Camutins, do conjunto Os Camutins e das escavações de Schaan (op.cit.) no teso Belém do conjunto Os Camutins. Durante as pesquisas de Schaan, no teso Belém ( $M-17 / \mathrm{J}-15), 24$ urnas funerárias foram escavadas, sendo que destas, em seis havia uma tanga, em um total de seis tangas, sendo duas vermelhas e quatro alaranjadas. Já nas escavações de Meggers e Evans no teso Camutins duas tangas foram escavadas em contextos funerários, sendo uma vermelha e uma com grafismos. No teso Guajará ( $\mathrm{M}-1 / \mathrm{j}-14)$, as escavações renderam 12 conjuntos funerários, entre urnas funerárias e recipientes menores, além de alguns sepultamentos associados às urnas.

As urnas maiores estavam depositadas nos níveis inferiores. Conforme mostra a ilustração abaixo, no lado sudeste, repousava a base da urna $\mathrm{O}$ a uma profundidade de 2,23 metros. Duas bacias, semelhante em forma, foram sobrepostas em seu pescoço e, dentro da urna estavam os fragmentos de uma das bacias, três tigelas quebradas de diferentes tamanhos, uma tanga vermelha e, a uma profundidade de 68 centímetros abaixo da borda, e, coberto por uma camada relativamente grande de fragmento, um esqueleto desarticulado. Ao lado de fora desta urna, a uma profundidade de 1,40 metros, ao nível da sua borda, estavam os fragmentos mal conservados de outro esqueleto associados a uma tanga vermelha.

Em um agrupamento de grandes urnas, entre as quais, algumas sobrepostas, estava a maior parte das tangas escavadas neste teso. A urna $\mathrm{L}$, uma grande urna Joanes Pintado, com a sua base repousando a 1,80 metros de profundidade, continha em seu fundo os ossos, cujos fêmures possuíam traço de tinta vermelha. A este indivíduo, no interior da urna, estava associada uma tanga alaranjada, bastante polida. Esta urna estava repousando sobre o fundo fragmentado de uma urna do tipo Inajá simples, a qual continha, além de sujeira, fragmentos de ossos humanos e uma tanga vermelha fragmentada. Junto à base do pescoço da urna $L$ foi encontrado um terceiro sepultamento contendo ossos humanos e uma tanga vermelha quebrada, 
A urna M, do tipo Inajás Simples, estava do lado norte da urna L. Seu interior foi preenchido com areia esbranquiçada e ali foram colocadas duas tigelas e os ossos de dois indivíduos. Sob as tigelas estavam os ossos desarticulados de um indivíduo, identificado como do sexo masculino, cujo crânio apresentava deformação intencional, fragmentos diversos, e, no centro do frasco, uma tanga vermelha completa. Abaixo destes ossos, havia um conjunto de ossos de um segundo indivíduo que foram identificados como de uma mulher entre 18 e 25 anos. Dentro da urna havia também os ossos de pequenos roedores e de aves, como o tuiuiú. Todos os ossos deste sepultamento estavam pintados de vermelho. Sobreposta a esta urna e também à urna L, estava a urna I, uma Joanes Pintado, que possuía ossos decompostos e uma tanga vermelha em seu interior. 


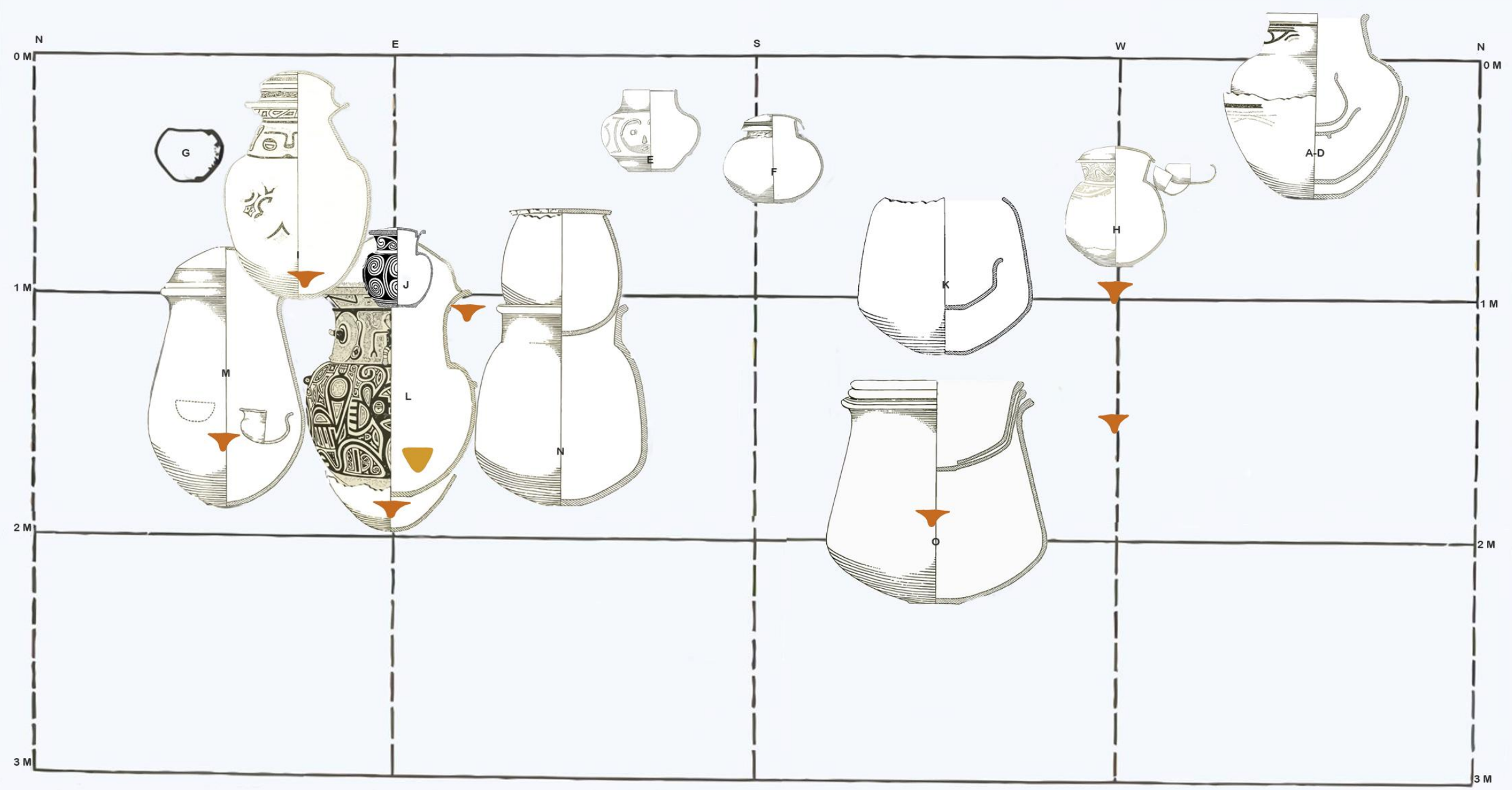

Figura 10. Perfil mostrando a disposição das tangas em contextos funerários no teso Guajará, Monte Carmelo (J-14). Redesenhado a partir de Meggers e Evans, 1957. 
Posteriormente Schaan (op.cit.) realizou cinco escavações no teso Belém ( $\mathrm{M}-17 / \mathrm{J}-15$, pertencente ao conjunto Os Camutins) que foram denominadas de "escavações 1, 2, 3, 4 e 5", e cujas proporções relativas de fragmentos de tangas são reproduzidas na tabela abaixo. Como mostra a tabela, as escavações 1 e 4 apresentaram uma maior concentração de fragmentos de tangas, tanto monocromáticas quanto com grafismos, mas é possível ver que as tangas de ambos os tipos aparecem em todas as escavações, contudo, os fragmentos monocromáticos são maioria nas cinco escavações. Outro dado relevante visto nesta tabela é a variedade de contextos nos quais os fragmentos de tangas são encontrados.

\begin{tabular}{|c|c|c|c|c|c|c|c|}
\hline \multirow{2}{*}{} & \multirow{2}{*}{ Tipo de área } & \multicolumn{2}{|c|}{ Monocromáticas } & \multicolumn{2}{|c|}{ Com grafismos } & \multicolumn{2}{|c|}{$\begin{array}{c}\text { Total de } \\
\text { fragmentos }\end{array}$} \\
\cline { 3 - 8 } & & Total & $\%$ & Total & $\%$ & Total & $\%$ \\
\hline Escavação 1 & $\begin{array}{c}\text { Produção de } \\
\text { cerâmica }\end{array}$ & 180 & 63,38 & 104 & 36.62 & 284 & 100.00 \\
\hline Escavação 2 & $\begin{array}{c}\text { Periferia do } \\
\text { sítio }\end{array}$ & 87 & 86,14 & 14 & 13.86 & 101 & 100.00 \\
\hline Escavação 3 & $\begin{array}{c}\text { Habitação } \\
\text { Escavação 4 }\end{array}$ & 57 & 78.08 & 16 & 21.92 & 73 & 100.00 \\
\hline Escavação 5 & Área funerária & 17 & 62.96 & 10 & 37.04 & 27 & 100.00 \\
\hline Total & & 478 & 68.88 & 216 & 31.12 & 694 & 100.00 \\
\hline
\end{tabular}

Tabela 1. Tabela adaptada de Schaan (2004)

As duas áreas com maior concentração de fragmentos de tangas seriam de atividades ao céu aberto, como de produção cerâmica e descarte de resíduos. A escavação 1 , realizada próximo ao centro do topo do teso, revelou grupos de grandes fragmentos, pedaços de argila, fragmentos de tanga, pequenos objetos e um banco, o que para Schaan (2004:205), seria uma área aberta onde a cerâmica era produzida. Já na escavação 4 foi encontrada terra 
preta $^{23}$ com grandes fragmentos cerâmicos, entre os quais vários de tangas, e vasos fragmentados. Por esta razão Schaan (2004:214) considerou esta como uma área de descarte, talvez os fundos de uma casa. Já as outras escavações revelaram áreas funerárias, áreas domésticas, entre outras.

Embora os dados de Schaan (op.cit.) apontem para uma circulação de fragmentos de tangas em contextos diversos, os contextos mais bem descritos sobre as tangas são os funerários. Apesar de serem poucos os sepultamentos bem descritos, em vista da quantidade de tangas existentes em museus, um levantamento destes contextos pode ser crítico para vislumbrar os padrões nos quais estas peças foram depositadas em contextos funerários. Com isto, poderia ser verificado, por exemplo, os tipos de urnas funerárias nos quais estas peças foram encontradas e os materiais associados.

As descrições e registros vistos aqui permitem vislumbrar as diferentes ocorrências de tangas em sepultamentos. Elas podem ser encontradas nos seguintes arranjos funerários:

- junto ou no fundo das urnas, sob os ossos;

- dentro de urnas com um ou mais de um sepultamentos, podendo haver casos de mais de uma tanga por urna, e podem estar quebradas no interior das urnas;

- dentro de urnas simples maiores que abrigam outra urna, no espaço entre elas;

- do lado de fora junto às urnas, sozinhas ou junto com pratos e tigelas;

- do lado de fora, ao lado das urnas, em sepultamentos diretos no solo.

Quando aparecem dentro das urnas podem ser encontradas com ossos humanos e animais pintados de vermelhos, fragmentos cerâmicos diversos, aparentemente quebrados intencionalmente, tigelas, em alguns casos, estatuetas-chocalho, entre outros. Podem estar dentro de grandes urnas pintadas, grandes urnas simples, urnas com outras urnas em seu interior ou em urnas com outros recipientes no interior. Segundo o levantamento que fizemos, verificamos que podem também aparecer dentro das urnas antropozoomorfas

\footnotetext{
${ }^{23}$ A terra preta é formada pela decomposição de restos orgânicos, por isto estes solos sinalizam a presença de lixo descartado.
} 
do tipo Pacoval Inciso, do tipo Arari Exciso Vermelho, e em vários tipos de urnas Joanes Pintado, o que mostra que não estão associadas a um ou outro tipo de urna (Anexo 1).

Alguns autores sugeriram que as tangas não são encontradas em sepultamentos com cremação. Meggers e Evans (op.cit.), por exemplo, sugerem que a estratigrafia dos sepultamentos no teso Guajará, no Monte Carmelo, indicaria que os enterros secundários em urnas, associados às tangas, estariam sendo substituídos pela cremação, com a qual as tangas não são encontradas. Segundo estes autores, na última parte da sequência estratigráfica, as urnas seriam menores e menos ornamentadas do que aquelas usadas para o enterro secundário, e, tangas nunca estariam associadas. Contudo, como observa Schaan (1997: 89), estes dois tipos de sepultamentos podem aparecer juntos.

\subsubsection{A distribuição das tangas com grafismos e das tangas monocromáticas}

As descrições e relatos sobre os sítios da fase marajoara mencionam os fragmentos cerâmicos na superfície e, entre estes, os fragmentos de tangas. Nestes relatos e descrições parece que a frequência dos tipos de tanga varia de sítio para sítio.

Esta tendência parece bem marcada nos sítios da região do rio Anajás, onde parece haver uma maior frequência de tangas monocromáticas em relação às tangas com grafismos, conforme pode ser visto na tabela abaixo. Desde os primeiro relatos e descrições dos sítios desta região é mencionada a maior concentração de fragmentos de tangas vermelhas, Derby, por exemplo, relata que no teso Belém (M-17), do conjunto Os Camutins os fragmentos de tangas são abundantes e, embora, existam fragmentos com grafismos, os fragmentos vermelhos são mais comuns (Hartt, 1885: 25), o que foi confirmado por pesquisas posteriores.

Meggers e Evans (1957) fizeram, neste mesmo teso, um poço teste de 1,5 metros quadrados, atingindo uma profundidade de 1,20 metros, o que produziu um total de 30 fragmentos vermelhos e 18 com grafismos, isto é, 62,5 
$\%$ da amostra coletada é de fragmentos vermelhos. As escavações de Schaan (2004), ali, produziram um total de 694 fragmentos de tangas, sendo que destes $68,88 \%$, ou 478 , eram vermelhos e 216 com grafismos. Tendência semelhante é vista no teso Camutins (M-1), onde as escavações de Schaan (2004) produziram 138 fragmentos de tangas, destes 118 eram vermelhas e 20 de tangas com grafismos, ou seja, $85,51 \%$ da amostra era de tangas vermelhas.

\begin{tabular}{|c|c|c|c|c|c|c|}
\hline Sitio & Coletor & $\begin{array}{c}\text { Tangas com } \\
\text { grafimos }\end{array}$ & $\%$ & $\begin{array}{c}\text { Tangas } \\
\text { monocromáticas }\end{array}$ & $\%$ & Total \\
\hline Belém & $\begin{array}{c}\text { Meggers e } \\
\text { Evans }\end{array}$ & 18 & 37,5 & 30 & 62,5 & 48 \\
\hline Belém & Schaan & 216 & 31.12 & 478 & 68,88 & 694 \\
\hline Camutins & Schaan & 20 & 14.49 & 118 & 85,51 & 138 \\
\hline
\end{tabular}

Tabela 2. Frequência de fragmentos de tangas com grafismos e monocromáticas nos sítios do conjunto Os Camutins.

O mesmo padrão é visto nas escavações que produziram tangas inteiras neste conjunto de teso. Meggers e Evans (op.cit.) escavaram dois grupos funerários no teso Camutins (M-1), totalizando, entre os dois, 7 urnas de diferentes dimensões e duas tangas, sendo um vermelha e outra com grafismos, cada uma associada a uma urna, como já comentado acima. A escavação de Hilbert nos tesos do Alto Camutins, em 1950, produziu, no teso Furinho, 05 tangas em urnas, a maior parte vermelha (três vermelhas e duas com grafismos) e em Cuieiras uma tanga monocromática encontrada também dentro de uma urna (Hilbert, 1952, Meggers e Evans (op.cit.). Pesquisas posteriores, realizadas por Schaan (op.cit.) no teso Belém resultaram em 24 sepultamentos escavados, dos quais 6 continham tangas monocromáticas, sendo 4 alaranjadas e duas vermelhas.

Ainda na região do Rio Anajás, mas em outro conjunto de tesos, o Monte Carmelo (J-14), as pesquisas, apesar de poucas, apontam para uma maior frequência de tangas monocromáticas. As investigações mais antigas nos tesos deste conjunto não são bem detalhadas e fornecem poucas informações. 
Os registros mais detalhados deste teso foram feitos por Meggers e Evans (op.cit.), entretanto, nem todos os tesos foram bem investigados. Apesar de não haverem feito escavações no teso Monte Carmelo (M-2) estes autores relatam a presença de fragmentos de tangas de ambos os tipos, assim como de fragmentos cerâmicos diversos, na superfície. Na superfície do teso Bacatal (M-3) foram registrados 8 fragmentos de tangas vermelhas e nenhum com grafismos. No teso Guajará (M-1), o mais bem investigado, foram escavados 11 sepultamentos de vários tipos aos quais estavam associadas 07 tangas monocromáticas, das quais 6 eram vermelhas e uma alaranjada

Os tesos da região do lago Arari e do rio Arari talvez tenham sido os mais explorados da ilha do Marajó. Uma parte significativa das tangas das coleções de vários museus é proveniente dos tesos Pacoval e do teso Severino, nesta região. Contudo, não há dados sobre a quantidade de tangas retirada em cada exploração que possibilitem quantificar a frequência dos tipos nestes tesos. Aliás, os relatos e descrições quando existem, não diferenciam um tipo do outro.

O teso mais conhecido desta região é o Pacoval. Conhecido e explorado para retirada de sua cerâmica desde 1870 , são poucas as descrições que possibilitam ter um vislumbre sobre a frequência de tangas ali. Lange (1914:315-316) relata ter descoberto centenas de fragmentos de tangas neste teso, muitas com lindos grafismos e outras apenas pintadas de um vermelho forte, contudo, não fornece uma quantificação dos fragmentos. Os únicos dados mais detalhados sobre este teso estão descritos em Hilbert (1952). Em 1950 quando este autor visitou o sítio, pouco restava do teso descrito por Hartt, Ferreira Pena, Ladislau Neto (1885) e Lange (1914). O sítio havia sido reduzido a um amontoado de cacos. Ali, a coleta produziu cerca de 102 fragmentos de tangas, dos quais 66,5\% eram de tangas com grafismos e 33,5 \% de tangas monocromáticas (Meggers e Evans, 1957:319). Hilbert também escavou no teso Severino em 1951, onde abriu três poços teste em vários pontos, encontrando cacos a uma profundidade de 20 a $50 \mathrm{~cm}$. Dos 146 cacos recolhidos nesta escavação, 20 fragmentos eram de tangas, dos quais 13 eram de tangas com grafismos e 7 de tangas monocromáticas.

Como visto, as pesquisas sugerem uma maior frequência de tangas monocromáticas nos sítios do rio Anajás. Por outro lado, apesar das poucas 
pesquisas sistemáticas nos sítios da região do Lago Arari e do rio Arari, os poucos dados que temos para esta região sugerem uma frequência maior de tangas com grafismos. Caso os dados reunidos aqui sejam representativos podemos sugerir que nos tesos da região do lago Arari as tangas com grafismos eram mais utilizadas, enquanto nos sítios do Rio Anajás as tangas vermelhas eram mais comuns.

Esta possível predominância de tangas monocromáticas nos sítios da região do rio Anajás explicaria o porquê de Meggers e Evans (op.cit.) e Schaan (op.cit.) terem encontrado tangas vermelhas predominantemente associadas a grandes urnas decoradas.

Se por um lado, a frequência das tangas com grafismos e das tangas monocromáticas, sejam inteiras ou fragmentos, varie de uma região para a outra, parece também que a frequência de tangas varia de um sítio para o outro, havendo sítios em que a frequência das tangas é maior, enquanto em outros, é menor. Meggers e Evans (op.cit.) relatam que em um corte de 1,5 metros quadrados por 2,25 metros de profundidade, realizado no teso Inajasal $^{24}(\mathrm{M}-14)$, só foram produzidos fragmentos de tangas no nível 0.75-0.90 m. com três fragmentos vermelhos. Já os tesos Furinho (M-34) e Cuieiras (M30), segundo Hilbert (1952:18-19), apresentam uma escassez de fragmentos dos dois tipos, o que é bem representado na coleção 006 de fragmentos de tangas do MAE-USP, onde não há sequer um único fragmento de tanga provenientes destes tesos ${ }^{25}$. Segundo Schaan (op.cit.) em alguns deste conjunto, como Camutinzinho (M-16) os fragmentos de tangas estavam ausentes da superfície.

Outro aspecto importante que chama a atenção diz respeito à frequência dos fragmentos de tangas em relação a outros fragmentos cerâmicos. De acordo com os dados que podem ser vistos na tabela abaixo, a frequência de tangas varia entre os sítios do rio Anajás e os sítios do Lago Arari. Nos tesos do Rio Anajás, representados pelo teso Camutins (M-1 de J-15) e pelo teso Belém (M-17), os fragmentos de tangas correspondem a 4,36\% e 3,89\%, respectivamente, enquanto que nos tesos do Lago Arari, representados pelo

\footnotetext{
${ }^{24}$ De acordo com Schaan (op.cit.) este teso é um monte habitação, com isto a ausência de cerâmica decorada ali seria esperada.

${ }^{25}$ As peças escavadas e coletadas nas superfícies destes tesos foram enviadas ao Museu Paulista e hoje estão depositadas no MAE-USP.
} 
Pacoval e pelo Severino a frequência de fragmentos de tangas é de $13,7 \%$ e $13,1 \%$, respectivamente. Caso estes dados sejam significativos, podemos sugerir que nos tesos do Lago Arari havia uma maior produção de tangas cerâmicas.

\begin{tabular}{|c|c|c|c|c|}
\hline \multirow{2}{*}{ Região } & Sítio & $\begin{array}{c}\text { Total de } \\
\text { fragmentos }\end{array}$ & $\begin{array}{c}\text { Fragmentos de } \\
\text { tangas }\end{array}$ & $\%$ \\
\hline \multirow{2}{*}{ Rio Anajás } & Camutins & 3.166 & 138 & 4,36 \\
\cline { 2 - 5 } & Belém & 17.840 & 694 & 3,89 \\
\hline \multirow{2}{*}{ Lago Arari } & Pacoval & 777 & 102 & 13,1 \\
\cline { 2 - 5 } & Severino & 146 & 20 & 13,7 \\
\hline
\end{tabular}

Tabela 3. Diferença entre a frequência de fragmentos de tangas entre os sítios do Rio Anajás e do Lago Arari.

Com os dados apresentados aqui sugerimos que as tangas monocromáticas são maioria nos sítios do Rio Anajás, enquanto que aquelas com grafismos parecem mais comuns nos sítios do Lago e Rio Arari. Em relação à frequência das tangas no registro arqueológico, os dados que temos sugerem uma maior produção delas nos sítios do Lago e Rio Arari do que nos sítios Rio Anajás. Evidentemente, apesar do grande número de tangas conhecidas poucas são aquelas provenientes de escavações sistemáticas, por isto, estas sugestões precisariam ser testadas em futuras pesquisas, sobretudo, nos sítios do lago Arari, onde poucas pesquisas sistemáticas foram desenvolvidas.

\subsubsection{Análise de desgaste nos orifícios}

Um aspecto crucial para ajudar a entender uso e descarte das tangas diz respeito às marcas de uso localizadas nestas peças. Autores como Prous e Lima (2011) acreditam que as descamações existentes na face interna de várias tangas poderiam ter sido causadas pelo contato desta superfície com o suor corporal, ou seja, isto poderia ser considerado um marcador de uso. Ao 
longo desta pesquisa, percebemos também que os orifícios de amarração de várias tangas apresentam micro-fraturas ao seu redor, contudo, não podemos afirmar se tais micro-fraturas foram causadas pelo atrito do cordão de amarração junto ao orifício durante o movimento ou se foram causadas somente pelo acondicionamento deste cordão. Apesar da existência destas características que podem indicar o uso, acreditamos que a análise do desgaste produzido junto aos orifícios de amarração das peças, além de mais confiável, é o suficiente para os objetivos desta pesquisa.

Próximo a cada extremidade da tanga há um orifício para fixar um cordão de amarração, são três no total. Eles estão localizados, geralmente, entre 1,9 e 3,4 cm de cada extremidade, variando de acordo com a largura destas pontas (Meggers e Evans, 1957:382). Tais orifícios, segundo Prous e Lima (op.cit.), apresentam diâmetro variável entre 1,5 e 2,3 mm, embora tenhamos, ao longo de nossa pesquisa, visto peças com orifícios maiores, como por exemplo, em uma tanga da coleção Oliveira, depositada no Museu do Estado de Pernambuco, que apresentou um diâmetro de $0,5 \mathrm{~mm}$.

A quantidade de desgaste produzida pelo atrito do cordão junto aos orifícios pode variar de nenhuma a um sulco profundo que se estende por todo o caminho entre o orifício e a extremidade da peça (Meggers e Evans, op.cit.). Somamos a isto, baseados em nossa observação, o fato de existir peças onde nem todos os orifícios possuem sulcos (canaletas) de desgaste, ou ainda, com os seus orifícios com diferentes graus de desgaste. Outras variáveis influenciam na observação do desgaste, como por exemplo, a integridade das peças. Com isto, só é possível observar o desgaste em peças completas ou que possuem pelo menos uma de suas extremidades.

A análise das marcas de desgaste vem sendo feita desde Meggers e Evans (op.cit.) para a formulação de hipóteses sobre as tangas. Estes autores tabularam os dados de 110 fragmentos com orifícios recolhidos durante as suas escavações em J-14 e J-15 e, com isto, obtiveram as porcentagens vistas na tabela abaixo: 


\begin{tabular}{|c|c|c|c|c|c|c|c|c|}
\hline \multicolumn{7}{|c|}{ Tabulação dos dados provenientes da análise do desgaste dos orifícios das tangas } \\
feita por Meggers e Evans \\
\hline & \multicolumn{2}{|c|}{ Sem uso } & \multicolumn{2}{c|}{ Marca suave } & Sulco profundo & \multicolumn{2}{|c|}{ Total } \\
\hline Tipo & Número & Percent. & Número & Percent. & Número & Percent. & Número & Percent. \\
\hline Simples & 27 & 32.6 & 34 & 40.9 & 22 & 26.5 & 83 & 100 \\
\hline $\begin{array}{c}\text { C/ } \\
\text { grafismos }\end{array}$ & 18 & 66.6 & 8 & 29.6 & 1 & 3.8 & 27 & 100 \\
\hline
\end{tabular}

Tabela 4. Diferenças no desgaste sobre os fragmentos de tangas escavados por Meggers e Evans (1957: 282).

De acordo com isto, 9 dos 27 fragmentos com grafismos analisados, ou seja, 33,4\% apresentaram marcas de desgaste, enquanto que 56 dos 83 fragmentos simples, isto é, 67,4\% apresentaram marcas. Este resultado sugeriu aos autores que as tangas com grafismos teriam tido um uso predominantemente cerimonial, enquanto que as simples teriam tido um uso maior.

Pesquisas posteriores efetuadas por Schaan (1997:134-136) demonstraram que as marcas dos sulcos de desgaste não estão associadas a um ou outro tipo de tanga. A tabulação dos dados de 284 fragmentos de extremidades com orifícios mostrou que 82 dos 89 fragmentos com grafismos, ou seja, 92,13\% apresentaram marca de uso, enquanto que 161 dos 163 fragmentos simples, isto é, $98,77 \%$ apresentaram marca. Com isto, os dados desta autora mostram que não há diferenças significativas entre o uso dos dois tipos, sugerindo que seriam igualmente usados. Para Prous e Lima (20011:247) os dois tipos de tangas também teriam tido a mesma frequência de uso.

Uma vez que os estudos demonstram não haver diferença na frequência de uso entre os dois tipos de tangas, analisamos os orifícios somente de tangas com grafismos, em um total de 210 peças. Destas, 153 foram observadas pessoalmente em análise dirigida por nós. Para a verificação das marcas usamos uma lupa eletrônica e na impossibilidade de usar uma desta utilizamos uma lupa de mão. As outras 57 peças foram analisadas por meio de fotografias, em muitos casos em alta resolução, permitindo ampliar os detalhes. 
Algumas fotografias foram divulgadas em livros, catálogos, sites de museus internacionais e casas de leilões.

O objetivo era verificar a existência ou ausência de marcas de desgaste, por esta razão não nos detivemos na intensidade deste desgaste. Quando havia canaleta de desgaste em pelo menos um dos orifícios, consideramos tal ocorrência como marca de uso. A ausência destas canaletas em todos os orifícios foi considerada como sem marca de uso. Já a inexistência de todos os orifícios das tangas, de modo a impossibilitar a existência ou ausência destas marcas, foi considerada como indeterminado.
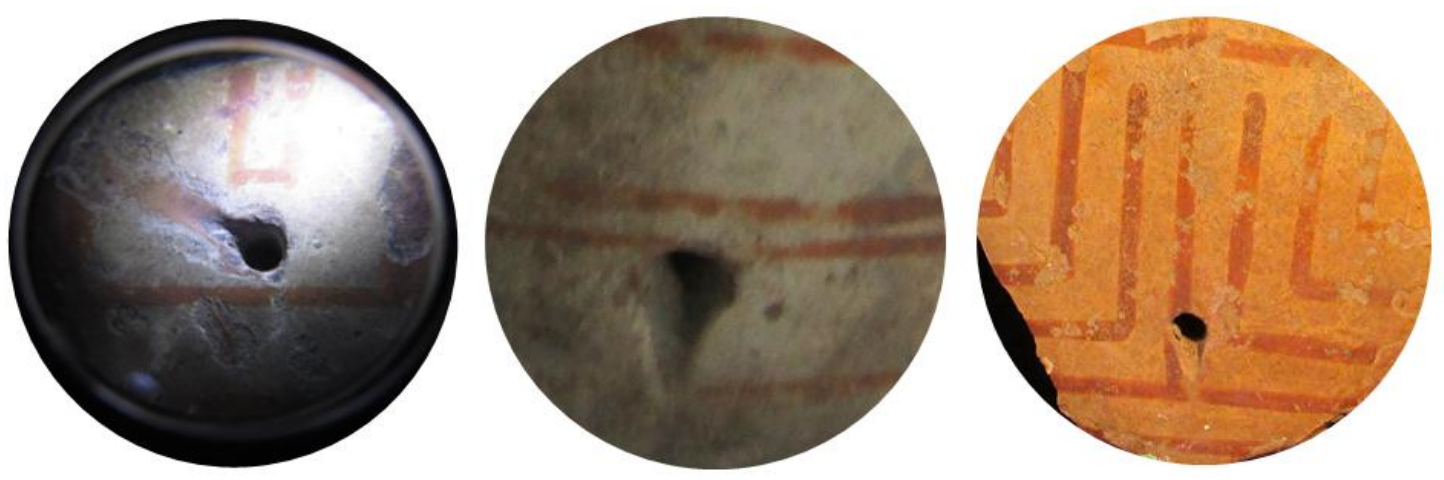

Figura 11. Orifícios de tangas apresentando marcas de desgaste.

Os resultados obtidos com esta análise são os seguintes. 54,7\% das tangas analisadas apresentou marca de desgaste de alguma intensidade junto aos seus orifícios demonstrando que esta significativa parcela da nossa amostra foi usada antes do seu descarte. 3,3 \% da amostra não pôde ser determinada em virtude da ausência de todos os seus orifícios.

Os outros $42 \%$ da amostra não apresentou desgaste junto aos orifícios. Segundo Prous e Lima (2011:247) a ausência de desgaste dos orifícios poderia ser resultado da utilização da tanga por uma pessoa mais corpulenta de modo a pressionar o cordão para fora, o que não causaria as marcas de desgaste. Entretanto, variáveis, como por exemplo, usos de diferentes tipos de cordão, uns produzindo mais desgastes e outros menos, ou nenhum, podem ter gerado os diferentes registros. Por esta razão não temos como afirmar se estas peças foram usadas ou não, ou se foram menos usadas. Também não temos como afirmar se entre estas peças algumas foram ou não confeccionadas especificamente para acompanhar os mortos. Diante do exposto, podemos 
assegurar que pelo menos 115 peças de uma amostra de 210 apresentam marca de uso, isto é, foram usadas.

\begin{tabular}{|c|c|c|c|c|c|c|c|}
\hline \multicolumn{8}{|c|}{ Desgaste produzido nos orifícios das tangas com grafismos } \\
\hline \multicolumn{2}{|c|}{$\begin{array}{l}\text { Com marca de } \\
\text { desgaste }\end{array}$} & \multicolumn{2}{|c|}{$\begin{array}{l}\text { Sem marca de } \\
\text { desgaste }\end{array}$} & \multicolumn{2}{|c|}{ Indeterminado } & \multicolumn{2}{|c|}{ Total } \\
\hline Número & Porcent. & Número & Porcent. & Número & Porcent. & Número & Porcent. \\
\hline 115 & $54,7 \%$ & 88 & $42 \%$ & 07 & $3,3 \%$ & 210 & $100 \%$ \\
\hline
\end{tabular}

Tabela 5. Análise do desgaste nos orifícios das tangas com grafismos

Isto nos leva a outra questão: as tangas documentadas em contexto funerário apresentam desgaste em seus orifícios? Este é um aspecto que apesar de parecer óbvio ainda gera muitos mal-entendidos no que diz respeito aos contextos nos quais eram usadas. Isto pode ser traduzido na seguinte pergunta: as tangas eram confeccionadas especialmente para os mortos ou eram usadas pelos vivos e posteriormente os acompanhavam em seus sepultamentos, ou eram feitas para ambos?

Entre as 115 peças que apresentaram marcas de desgaste somente duas possuem alguma informação sobre o seu contexto. Uma foi coletada por Orville Derby dentro de uma urna funerária no teso Pacoval e a outra foi coletada por Victor Bandeira e Françoise Carel-Bandeira dentro de uma urna funerária no teso Camutins. Este número, contudo, sobe para 6 se incluirmos 4 tangas monocromáticas (uma alaranjada e três vermelhas) ${ }^{26}$ com desgastes em seus orifícios que foram examinadas por nós e que são provenientes de contextos funerários. Apesar de ser um número bastante reduzido em vista da amostra ele pode servir para formular hipóteses que possam ser testadas futuramente.

Conforme já pontuamos, apesar de haver na bibliografia sobre a fase marajoara um número significativo de relatos sobre tangas encontradas dentro

\footnotetext{
${ }^{26}$ Uma destas tangas é proveniente da escavação de Meggers e Evans (1957) no teso Guajará do conjunto Monte Carmelo e as outras são provenientes das escavações de Schaan (2004) no teso Belém do Os Camutins.
} 
de urnas, são poucas as descrições que possibilitam identificar tanto o tipo de tanga quando o tipo de urna na qual foi encontrada. De qualquer forma, os sepultamentos são os relatos mais bem descritos sobre os contextos das tangas.

Apesar de existir um número bem maior de tangas com grafismos do que tangas monocromáticas nos museus, estas últimas parecem ser maioria nos sepultamentos. Além disto, a maioria destas peças foi coletada em um período pré-científico, onde a descrição dos contextos era ignorada, ou é fruto de saque e escavações ilegais. Sem dúvida uma parcela destas tangas é proveniente de contextos funerários, todavia, não temos como relacioná-la a um ou outro sepultamento por falta de documentação. Com base nisto, podemos sugerir que uma parte significativa destes objetos não eram apenas itens de acompanhamento funerário, mas também tinham uso em outros contextos.

Com base em tudo o que foi comentado até agora sobre os contextos das tangas e sobre a análise das canaletas de desgaste dos seus orifícios que apontam não apenas para um uso funerário, propomos interpretar a sua circulação por contextos relacionados aos vivos e aos mortos à luz dos conhecimentos a respeito do ciclo de vida dos objetos nas sociedades ameríndias, com destaque especial à teoria da materialidade.

\section{Reflexões acerca do ciclo de vida das tangas}

Alguns autores têm sugerido que os padrões de quebra vistos em certos objetos podem ser o resultado de uma quebra intencional que visaria a sua desubjetivação. Para Barreto (2017) e Schaan (2001b), por exemplo, o padrão de quebra visto nas estatuetas cerâmicas marajoara, caracterizado pela decapitação destas, seria o resultado de uma quebra deliberada, de uma morte ritual das mesmas.

Em nossa análise percebemos que cerca de $67 \%$ das tangas vistas, de um número de 210, ou seja, 141 tangas, ou estavam fragmentadas, muitas delas faltando pelo menos uma de suas extremidades onde se localiza 0 orifício de amarração, ou haviam sido quebradas em grandes fragmentos. 
Tendo em vista que estas peças eram de uso pessoal e usadas junto ao corpo, ficando expostas a fluídos corporais diversos, podem ter sido compreendidas enquanto partes corpóreas destacadas das pessoas que as usavam. Além disto, em seus processos de fabricação podem ter incorporado dimensões subjetivas de quem as fabricou, tanto durante o processo de modelagem da peça como no processo de decoração de sua superfície.

Deste modo, é possível que na ocasião do falecimento de um membro do grupo, as suas extensões corporais não somente precisassem ser sepultadas junto, mas também destruídas, para evitar, ao mesmo tempo, tanto que fossem usadas por outros, quanto para impedir o morto de continuar entre os vivos por meio de suas extensões corpóreas. Isto explicaria a existência de tangas quebradas ao fundo de urnas funerárias, e explicaria também a grande quantidade de tangas sem as extremidades onde se localizam os seus orifícios de amarração.

Além disto, os próprios membros da sociedade podem ter sepultado junto aos mortos as suas tangas desgastadas ou quebradas, evitando deixá-las expostas. Como já comentado, muitas tangas foram encontradas dentro de potes e tigelas junto a sepultamentos e algumas vezes mais de uma tanga foi encontrada em uma urna funerária com o corpo de um único indivíduo. Estas tangas podem ter sido depositadas ao fim do seu ciclo de vida, quando se quebraram ou a sua pintura se desgastou. Entre vários grupos ameríndios, toma-se bastante cuidado com o descarte de partes corporais para que elas não sejam usadas em feitiços contra o seus donos, como por exemplo, entre alguns grupos do Alto Xingu, onde os feiticeiros se aproveitam de partes, como - cabelo, inadvertidamente descartadas, para lançar feitiços e, assim, envenenar os seus inimigos (Barros, 2003; Neto, 2006).

Deste modo, perceber estes objetos enquanto coeficientes de subjetividade ou partes destacadas de pessoas possibilita também a compreensão do porquê em um regime de materialidade aparentemente tão opulento quanto o marajoara, certo objetos considerados raros, e confeccionados em materiais inexistentes na llha de Marajó, como os itens líticos, como aqueles feitos em pedras verdes, tal como a nefrita e a amazonita, ao invés de serem transferidos a pessoas da família dos mortos eram sepultados junto com eles. 


\subsection{Os corpos pintados e a paramentação do corpo}

Neste capítulo, até aqui, revisitamos os contextos funerários das tangas, destacando a enorme variabilidade nas formas de sua deposição que indica que enquanto muitas podem ter sido sepultadas com as pessoas mortas outras podem ter sido depositadas posteriormente, já que os registros de certas escavações descrevem a sua deposição dentro de tigelas e pratos localizados junto aos sepultamentos, e alguns casos, mais de uma tanga depositada com o mesmo indivíduo. Destacamos também que as marcas de desgastes localizadas em seus orifícios apontam ao fato de que embora sejam associadas a contextos funerários, eram usadas antes de serem descartadas nestes contextos.

Com base nas lições vindas do mundo ameríndio que atentam que os objetos podem ser subjetivados por uma série de fatores, e por isto são considerados seres corporificados que assim como os humanos possuem um ciclo de vida (Santo Granero, op. cit.), sugerimos que as tangas podem ter sido subjetivadas pelo uso, por meio da troca de substâncias, sendo consideradas extensões corporais das pessoas para as quais foram feitas e, com isto, que algumas características vistas no seu modo de deposição possam estar relacionadas a um descarte visando cessar a manifestação desta sua subjetividade. Dito isto, apontaremos brevemente algumas características das tangas relacionadas à sua variabilidade que nos permitam refletir sobre a sua agentividade.

A modelagem das tangas segue um formato triangular que pode variar em tamanho. Vários autores observaram a variabilidade em relação à sua morfologia sugerindo que esta poderia se correlacionar às diferentes anatomias do corpo (Meggers e Evans, op.cit:; Netto, 1875; Palmatary, 1950; Schaan, op.cit.). No entanto, só recentemente é que foram descritas sistematicamente por Prous e Lima (2011). Os autores descreveram 3 tipos em relação à morfologia ${ }^{27}$ :

\footnotetext{
27 A falta de dados estratigráficos e contextuais impossibilita entender qual o significado desta variabilidade na morfologia das tangas, ou seja, se estas morfologias estavam associadas a diferenças regionais, cronológicas ou ambas, e mesmo se representavam alguma diferença interna aos grupos de pessoas que as usavam.
} 

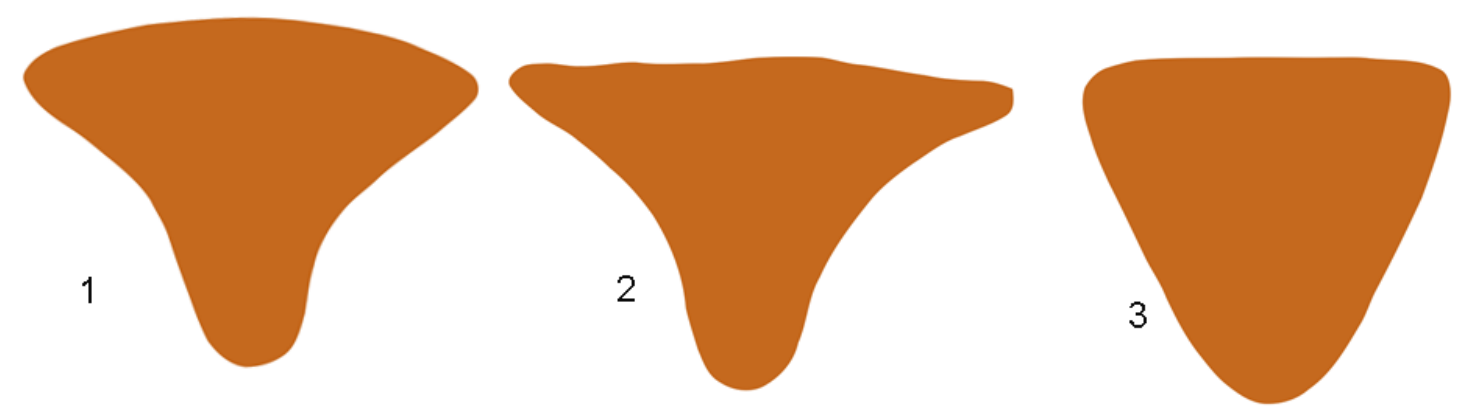

Figura 12. Morfologias das tangas de acordo com Prous e Lima (2011)

Morfologia 1. Corresponde a peças triangulares, com a borda superior reta, bordas laterais oblíquas suavemente côncavas e forte arqueamento.

Morfologia 2. Corresponde a peças com a largura da borda superior sempre maior do que o comprimento, borda inferior mais comprida e ponteaguda, e bordas laterais côncavas.

Morfologia 3. Caracterizada por peças cuja largura e altura são quase equivalentes, bordas laterais retas ou ligeiramente convexas e vértices mais arredondados.

As medições das tangas com grafismos feitas por nós são bem próximas àquelas vistas acima, como pode ser observado na tabela abaixo.

\begin{tabular}{|c|c|c|c|c|c|c|}
\hline \multirow{2}{*}{} & \multicolumn{4}{|c|}{ DIMENSÕES DAS TANGAS COM GRAFIMOS POR MORFOLOGIAS } \\
\cline { 2 - 7 } & \multicolumn{2}{|c|}{ Morf. 1 } & \multicolumn{2}{c|}{ Morf. 2 } & \multicolumn{2}{c|}{ Morf. 3 } \\
\cline { 2 - 7 } & Altura & Largura & Altura & Largura & Altura & Largura \\
\hline $\begin{array}{c}\text { Maior } \\
\text { medida }\end{array}$ & $16,5 \mathrm{~cm}$ & $14 \mathrm{~cm}$ & $20 \mathrm{~cm}$ & $14 \mathrm{~cm}$ & 13,5 & $13 \mathrm{~cm}$ \\
\hline $\begin{array}{c}\text { Menor } \\
\text { medida }\end{array}$ & $11 \mathrm{~cm}$ & $8,5 \mathrm{~cm}$ & $12,5 \mathrm{~cm}$ & 9 & 11,5 & $10 \mathrm{~cm}$ \\
\hline
\end{tabular}

Tabela 6. Dimensões verificadas nas tangas de acordo com as morfologias descritas por Prous e Lima (2011).

Como se nota na tabela, as dimensões das tangas podem variar bastante. Diferenças no tamanho das peças podem ser bem perceptíveis, com algumas relativamente grandes, por exemplo, alcançando uma largura de 20 $\mathrm{cm}$ e altura de $14 \mathrm{~cm}$, enquanto outras bastante pequenas chegam a uma largura de $6,5 \mathrm{~cm}$ e uma altura de $5,5 \mathrm{~cm}$, como é possível observar na figura 13. Para ter uma ideia, observamos 6 tangas que apresentaram dimensões 
bastantes reduzidas ${ }^{28}$, com larguras variando entre 9 e $5 \mathrm{~cm}$ e altura entre 6 e $9 \mathrm{~cm}$, todas da morfologia 2 .

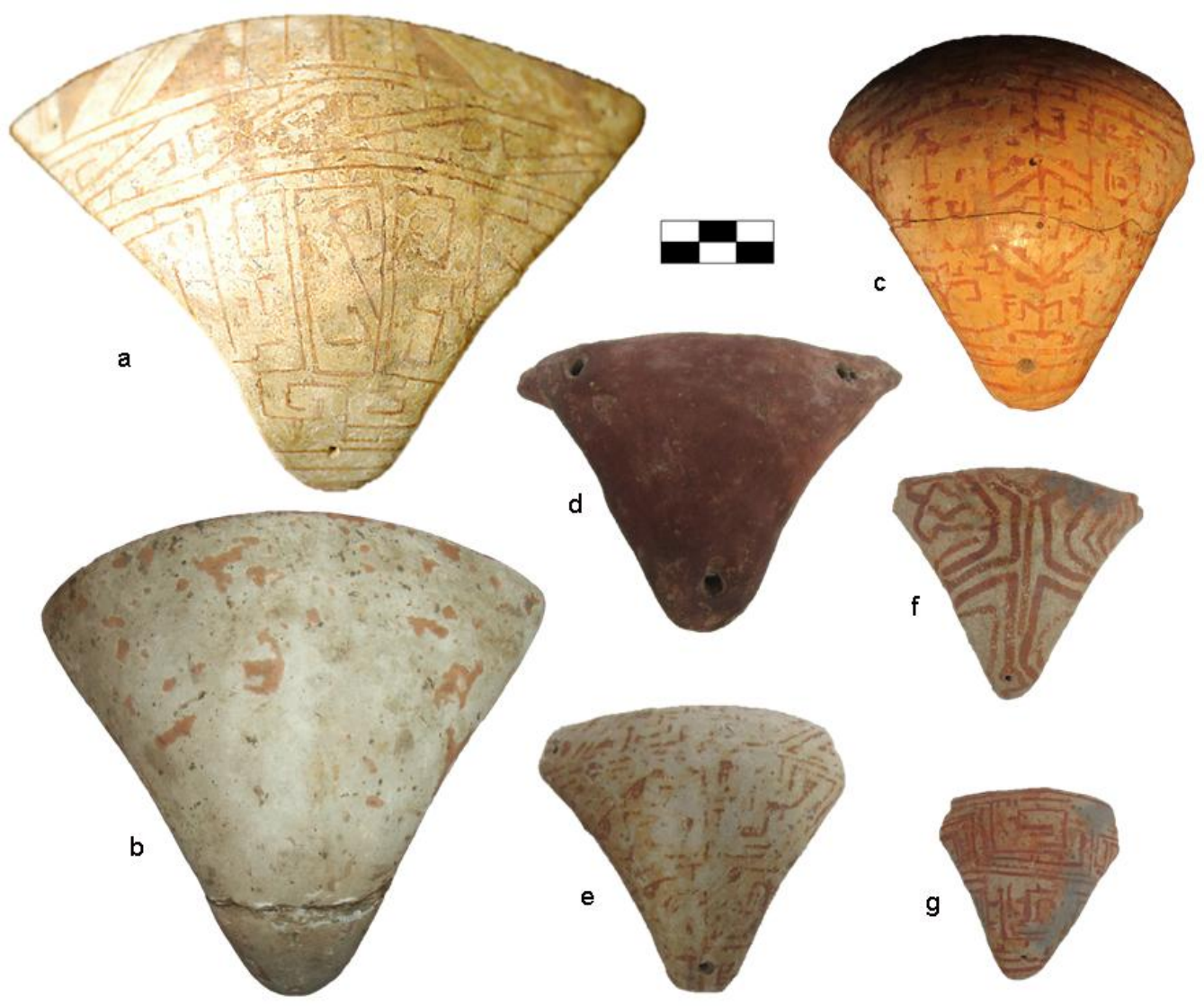

Figura 13. Comparação destacando diferença de dimensões entre as tangas.

a. Largura de $16,3 \mathrm{~cm}$ e altura de $10,5 \mathrm{~cm}$. Coleção ICBS/MAE-USP, Museu de Arqueologia e Etnologia, São Paulo.

b.. Largura de $14 \mathrm{~cm}$ e altura de 10,6 cm. Museu de Arqueologia e Etnologia, São Paulo.

c. Largura de $8,3 \mathrm{~cm}$ e altura de $7,7 \mathrm{~cm}$. Coleção Dita, Museu Paraense Emílio Goeldi, Belém.

d. Largura de 10, $8 \mathrm{~cm}$ e altura de 7,8 cm. Coleção Oliveira, Museu do Estado de Pernambuco, Recife.

e. Largura de $5,0 \mathrm{~cm}$ e altura de $7,5 \mathrm{~cm}$. Coleção Oliveira, Museu do Estado de Pernambuco, Recife.

f. Largura de $8,7 \mathrm{~cm}$ e altura de 9, $0 \mathrm{~cm}$. Coleção ICBS/MAE-USP, Museu de Arqueologia e Etnologia, São Paulo.

g. Largura de $5,6 \mathrm{~cm}$ e altura de $6,3 \mathrm{~cm}$. Coleção ICBS/MAE-USP, Museu de Arqueologia e Etnologia, São Paulo.

Dito isto, é importante destacar que as tangas eram confeccionadas com uma argila bastante fina. Uma análise de 57 fragmentos da coleção 006 do MAE/USP mostrou uma predominância de argila e pouco antiplástico mineral na composição. Curiosamente, o uso de caco moído como antiplástico na

\footnotetext{
${ }^{28}$ O número sobe para 7 se acrescentarmos uma tanga monocromática da coleção Oliveira, do acervo do Museu do Estado de Pernambuco, em Recife.
} 
produção da cerâmica cerimonial marajoara é bastante comum, como apontado por Schaan (2004, 2007b). No entanto, a análise dos fragmentos não mostrou o seu uso na composição da argila, o que poderia indicar um tratamento diferenciado para a argila das tangas. Em face, da pequena espessura das tangas, que varia entre 0,5 centrímetro e 1,0 centrímetro, mas com frequência possui 0.8 centrímetro, há a possibilidade de que o antiplástico tenha sido evitado, visando uma superfície mais lisa e regular, ou que a argila seja tão triturada que não deixa grãos perceptíveis na pasta queimada. Apesar disto, só um estudo comparativo focado na análise do antiplástico entre tangas e outros objetos, como urnas, pode confirmar se de fato a argila usada na confecção das tangas possuía um tratamento diferenciado ao de outros objetos.

Embora haja uma gama diversificada de tipos de decoração conferidos aos objetos durante a fase marajoara, como, pintura, incisão, excisão, modelagem e inúmeras formas de combinar estes, às tangas é conferida apenas pintura que varia entre uma pintura lisa que destaca uma cor uniforme, e entre uma pintura em pelo menos duas tonalidades cromáticas que se dá por meio da cobertura da tanga por um engobo de cor clara e por cima deste se aplicam grafismos de cor mais escura.

A cor das tintas usadas pode variar tanto em função de mudanças causadas pela temperatura da queima, quanto em função de certas combinações cromáticas. As tangas monocromáticas mais comuns são as tangas vermelhas que variam em tonalidade entre o vermelho e o vermelho escuro (figura 14a). São conhecidas também tangas engobadas de uma cor amarelo-alaranjada, descrita como tan, que foram registradas pela primeira vez por Meggers e Evans (1957) e posteriormente por Schaan $(2003,2004)$ e cujas coleções do ICBS/MAE-USP e do MPEG possuem exemplares (figura 14b).

Alguns autores registraram também a existência de tangas apenas engobadas de branco, como por exemplo, Simões (1967) em suas escavações nos rios Camará e Goiapí, Prous e Lima (op.cit.) e também Palmatary (1950: 293), segundo a qual há uma ou duas tangas decoradas apenas com uma fina camada de engobo branco, em ambos os lados, na coleção do University Museum. Tangas engobadas de uma cor creme foram registradas por Prous e 
Lima (2011: 250) na coleção Tom Wildi, depositada no Museu de Arqueologia e Etnologia da Universidade Federal de Santa Catarina (MArquE).

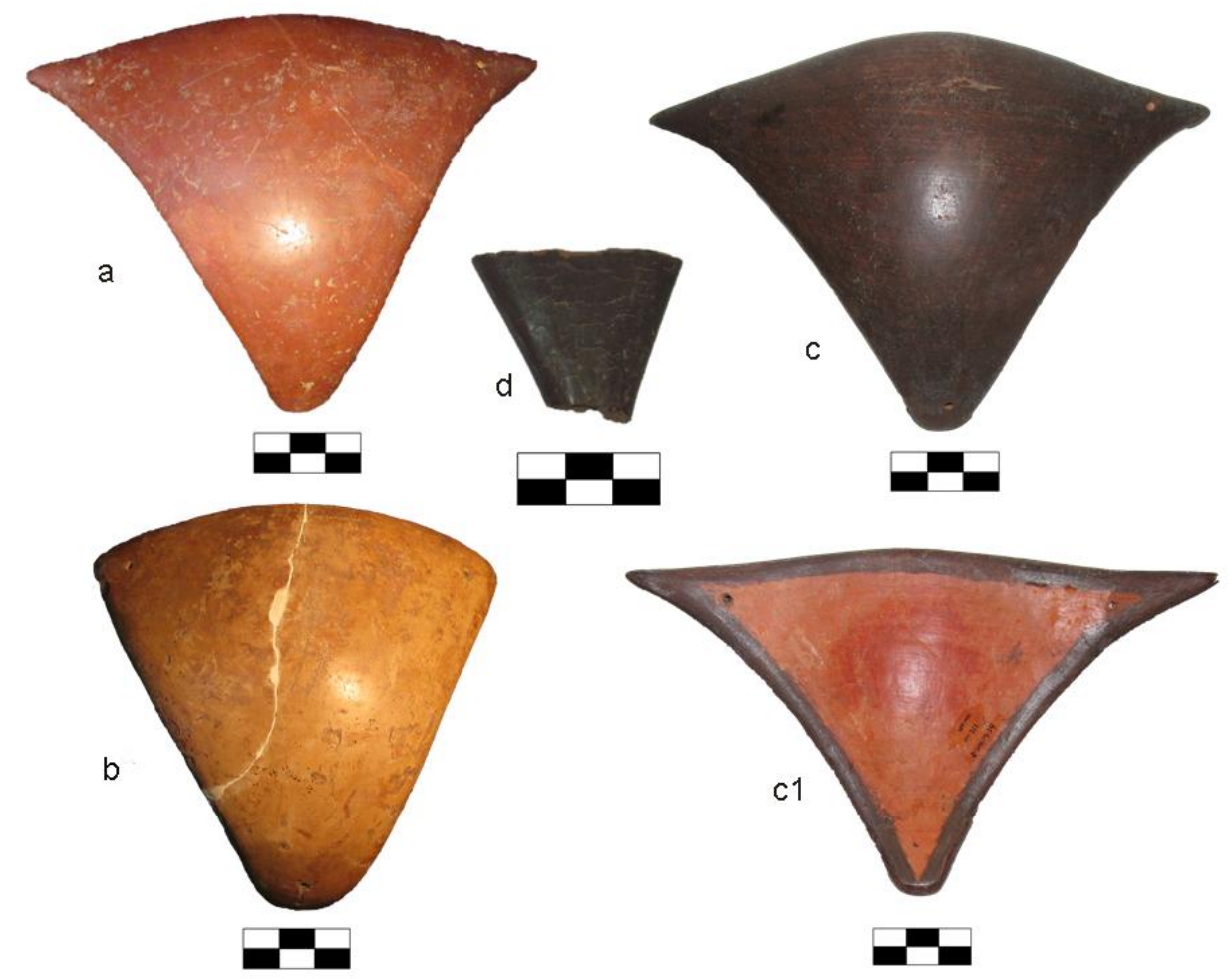

Figura 14. Tangas lisas.

A: Tanga com engobo vermelho. Antigo Instituto Cultural Banco Santos/ MAE-USP, São Paulo.

B: tanga engobada de amarelo-alaranjado. Museu Paraense Emilio Goeldi, Belém.

$\mathrm{C} / \mathrm{C} 1$. Tanga coberta com engobo duplo marrom escuro sobre vermelho. Antigo Instituto Cultural Banco Santos/ MAE-USP, São Paulo ICBS/MAE-USP, São Paulo.

$D$. Fragmento com engobo na cor preta nas duas faces. Museu de Arqueologia e Etnologia /USP, São Paulo.

Ao longo de nossa análise verificamos a existência de fragmentos de tangas apenas cobertas por um grosso engobo na cor preta em ambos os lados, na coleção 006 do MAE-USP (Figura 14d). Verificamos também a existência de duas tangas cobertas por engobo duplo, uma na coleção do ICBS-MAE e outra da coleção Dita/ IPHAN/ MPEG. Estas duas tangas foram previamente engobadas de vermelho ou vermelho alaranjado e cobertas por uma nova camada de engobo, em um caso marrom escuro (figura 14c), e em outro, preto. Curiosamente, esta sobreposição produz um efeito cromático bastante interessante. Dependendo da luz, ora mostra uma cor escura, ora reflete uma cor castanha (figura 14c1). 
Com base em nossas observações, bem como nos registro de autores como Meggers e Evans (1957), Palmatary (op.cit), Prous e Lima (op.cit.), Schaan (2004) resumimos na tabela seguinte as variações cromáticas das tangas monocromáticas.

\begin{tabular}{|c|}
\hline $\begin{array}{c}\text { Síntese das cores das tangas } \\
\text { monocromáticas }\end{array}$ \\
\hline Creme \\
\hline Branco \\
\hline Vermelho \\
\hline Amarelo-alaranjado \\
\hline Marrom escuro \\
\hline Preto \\
\hline Marrom sobre vermelho \\
\hline Preto sobre vermelho \\
\hline
\end{tabular}

Tabela 7. Cores que as tangas monocromáticas podem apresentar

As tangas com grafismos podem variar ainda mais. As suas superfícies podem ser cobertas por uma camada de engobo que varia entre o branco (figura 16c), o creme (figura 16a, 16b, 16d, 16e) e o alaranjado (figura 16b). Outras tonalidades, como por exemplo, amarelo e acinzentado, também muito frequentes, podem ser decorrentes do processo de queima para fixação do engobo (figura 15a e 15c). Em alguns casos, como naquelas tangas que apresentam um engobo avermelhado, pode ter havido mistura de tintas (Figura 15b).

Não procedemos nenhum tipo de análise dos pigmentos utilizados, portanto, não nos adentraremos em pormenores a respeito da composição das tintas. Deste modo, as considerações relativas às cores foram pautadas na observação, considerando as interferências óbvias como aquelas causadas pela queima, como mencionado acima. 

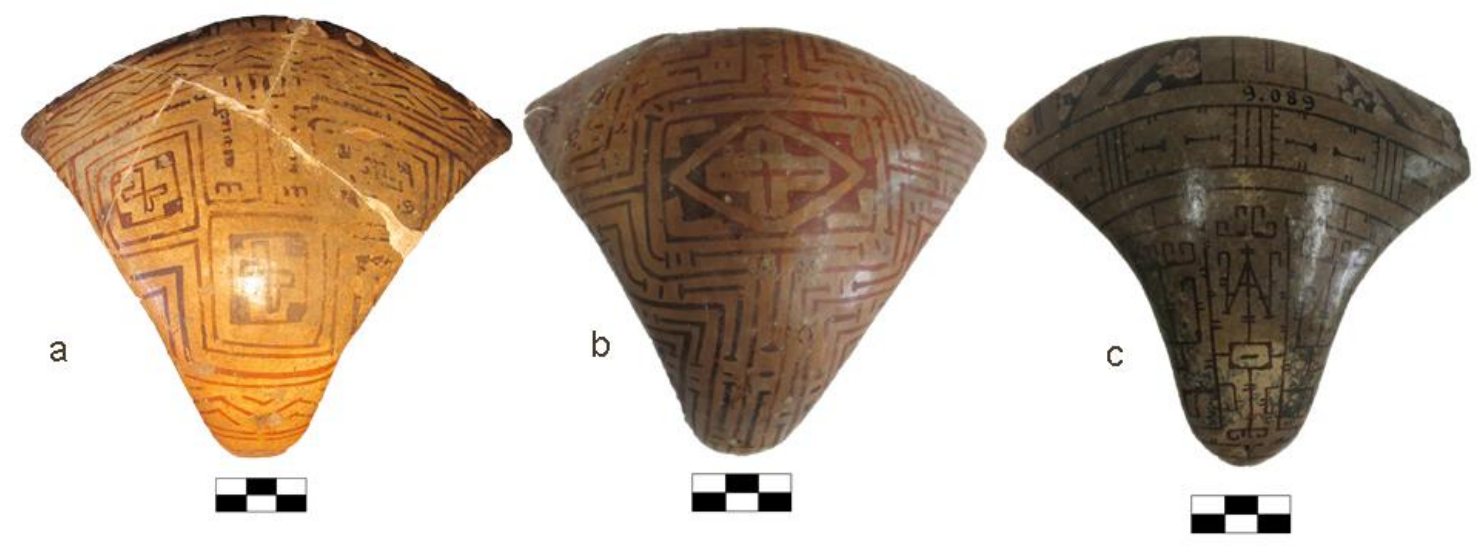

Figura 15. Tangas com grafismos com engobo de diferentes tonalidades.

A. Engobo de cor amarela decorrente provavelmente da queima. Museu Paraense

Emilio Goeldi, Belém.

B. Engobo avermelhado. Museu Nacional, Rio de Janeiro.

C. Engobo acinzentado decorrente da queima. Museu Nacional, Rio de Janeiro.

As cores utilizadas nos grafismos variam entre o vermelho e o marrom, que são as cores mais frequentes, o preto é mais incomum, mas registramos o seu uso em pelo menos 4 tangas com grafismos. O vermelho varia em tonalidades entre o vermelho claro e o vermelho escuro; o marrom pode variar entre castanho até um marrom escuro. Para registrar e sistematizar as cores usamos o código de cores Munsell, conforme consta na tabela abaixo.

\begin{tabular}{|c|c|c|c|c|c|}
\hline \multicolumn{3}{|c|}{ COR DO ENGOBO } & \multicolumn{3}{|c|}{ COR DOS GRAFISMOS } \\
\hline Branco & Creme & Alaranjado & Vermelho & Marrom & Preto \\
\hline \multirow[t]{4}{*}{$\begin{array}{l}\text { 5YR 8/1 } \\
\text { (White) }\end{array}$} & $\begin{array}{c}7.5 Y R \text { 7/2 } \\
\text { (pinkishi } \\
\text { gray) }\end{array}$ & $\begin{array}{l}\text { (5YR 7/8) } \\
\text { (Reddish } \\
\text { yellow) }\end{array}$ & $\begin{array}{c}\text { 10R 4/3 (weak } \\
\text { red) }\end{array}$ & $\begin{array}{c}2.5 y r 3.2 \\
\text { (dusky red) }\end{array}$ & $\begin{array}{l}\text { 5YR 2.5/1 } \\
\text { (black) }\end{array}$ \\
\hline & $\begin{array}{c}7.5 \mathrm{RY} 8 / 4 \\
(\text { pink) }\end{array}$ & & $\begin{array}{c}\text { 10R 3/1 } \\
\text { (dark reddish } \\
\text { gray) }\end{array}$ & $\begin{array}{l}2.5 Y R \text { 4/6 } \\
\text { (dark red) }\end{array}$ & \\
\hline & $\begin{array}{l}7.5 \text { YR 8/6 } \\
\text { (Reddish } \\
\text { yellow) }\end{array}$ & & 10R 4/6 (red) & $\begin{array}{c}2.5 Y R \text { 4/4 } \\
\text { (dusky red) }\end{array}$ & \\
\hline & $\begin{array}{c}5 \text { YR 7/3 } \\
\text { (pink) }\end{array}$ & & $\begin{array}{c}\text { (10R 5/8) } \\
\text { (red) }\end{array}$ & $\begin{array}{c}\text { 7.5YR } 3 / 4 \\
\text { (dark brown) }\end{array}$ & \\
\hline
\end{tabular}

Tabela 8. Cores vistas nas tangas com grafismos.

Além do uso de vermelho, marrom e preto, na composição dos padrões do painel gráfico pode ser empregada mais de uma tonalidade cromática, como 
no caso dos motivos desenhados em linhas duplas que podem ter o espaço entre as linhas preenchido por tinta de uma tonalidade diferente daquela utilizada nas linhas, semelhante a um retoque (figura 16d, 16e). Com isto, padrões em vermelho podem ter os espaços entre linhas preenchidos por tinta laranja (figura 16d, 16d1) ou por tinta branca alaranjada ou branca rosada, já os padrões em marrom podem ter as áreas entre linhas pintadas por uma tinta marrom mais clara, talvez mais diluída (figura 16e, 16e1).

Assim como Prous e Lima (op.cit.), também observamos que a cor dos grafismos, em uma mesma tanga, pode se alterar progressivamente de uma área à outra, passando, por exemplo, de uma cor marrom escura a uma cor mais clara, alaranjada (figura 16b, 16b1). Esta característica é bastante comum e, segundo Silvia Cunha Lima (comunicação pessoal), estas áreas mais claras poderiam decorrer do processo de queima quando a cor da tinta, em uma camada menos espessa, reage à temperatura e se altera. De fato, a análise dos grafismos de várias tangas, em uma lupa eletrônica, mostrou que a camada de tinta nestas áreas é mais fina. 


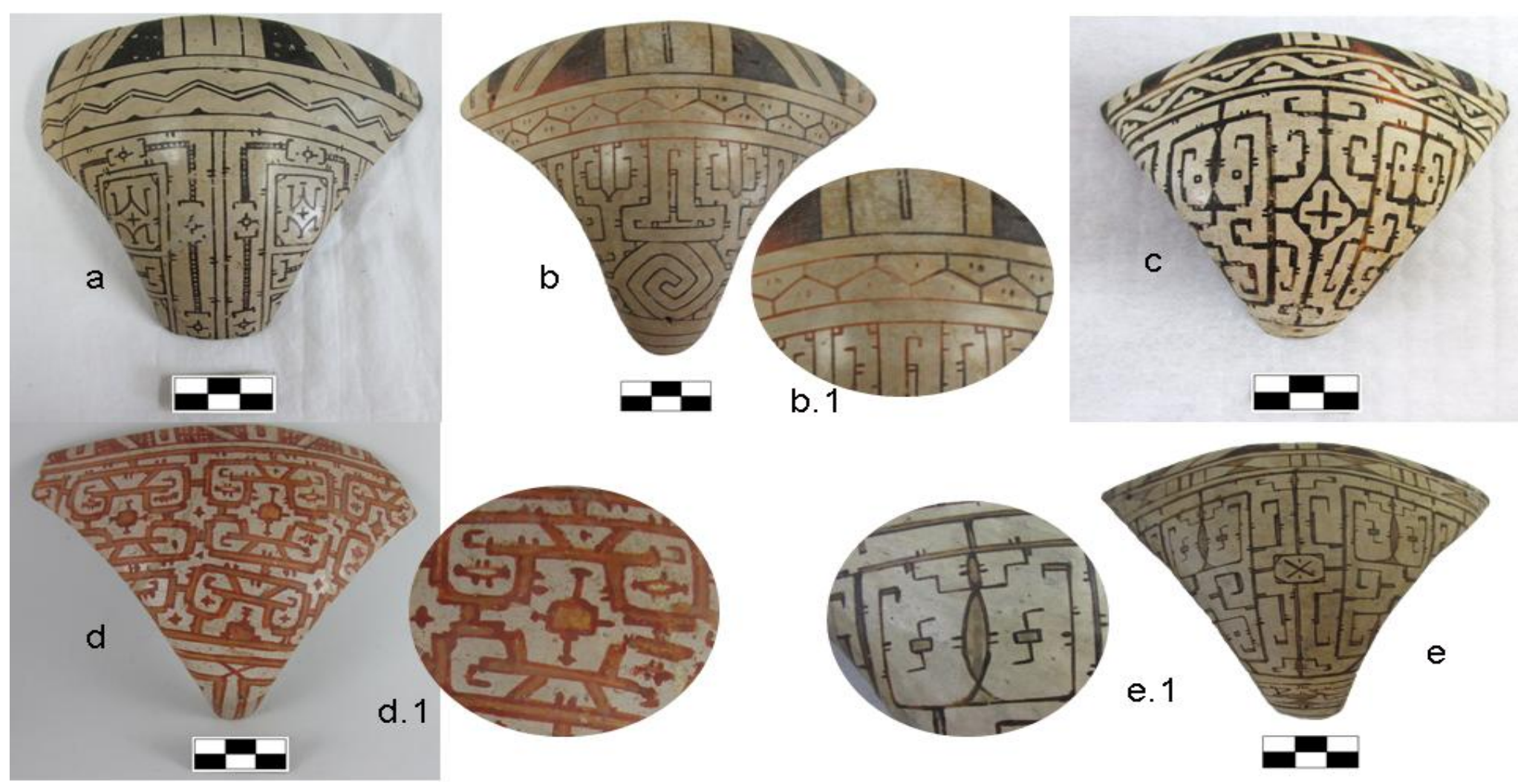

Figura 16. Variação cromática das tangas com grafismos.

A. Tanga apresentando grafismos pretos sobre engobo creme. Museu Nacional, Rio de Janeiro. B. Tanga com grafismos marrons apresentando áreas mais claras em vermelho. Museu Nacional, Rio de Janeiro. B1. Detalhe mostrando as áreas desbotadas. C. Tanga com grafismos marrons escuros sobre branco. Coleção Oliveira. Museu do Estado de Pernambuco, Recife. D. Tanga com grafismos vermelho com áreas preenchidas por tinta laranja sobre creme. ICBS/MAE-USP, São Paulo. D1. Detalhe mostrando as áreas com tinta vermelha e laranja. E. Tanga com grafismos marrons com áreas preenchidas por tinta marrom clara/ diluída. Museu do Estado de Pernambuco, Recife. E1. Detalhe mostrando a tinta mais clara. 
Com base nas observações anteriores sintetizamos as seguintes variações cromáticas:

\begin{tabular}{|c|c|c|}
\hline \multicolumn{2}{|c|}{ Composições cromáticas empregadas nas tangas } \\
\hline VERMELHO & MARROM & PRETO \\
\hline Vermelho sobre branco & Marrom sobre branco & Preto sobre branco. \\
\hline $\begin{array}{c}\text { Vermelho sobre creme } \\
\text { Vermelho com retoque sobre } \\
\text { branco }\end{array}$ & $\begin{array}{c}\text { Marrom com retoque sobre } \\
\text { branco }\end{array}$ & \\
\hline $\begin{array}{c}\text { Vermelho com retoque sobre } \\
\text { creme }\end{array}$ & Marrom sobre creme com \\
retoque & \\
\hline \begin{tabular}{l} 
Vermelho sobre alaranjado \\
\hline
\end{tabular} & & \\
\hline
\end{tabular}

Tabela 9. Combinações cromáticas empregadas nas tangas com grafismos.

Diante do mostrado até aqui, sem considerarmos ainda os campos gráficos, percebe-se que são três os aspectos relacionados à variabilidade das tangas: variações na morfologia, dimensões, cores e forma de trabalhar as suas superfícies com estas cores.

Todas estas características, dentro da dimensão da variabilidade artefatual, poderiam ser referentes a diferenças regionais ou cronológicas que demandariam mais dados contextuais e estratigráficos para a sua análise. Além disto, todas estas características podem ter sido estruturadas socialmente. Para se ter uma ideia, comparemos brevemente com algumas peças da vestimenta dos Wajana, em cuja produção estes aspectos estão socialmente imbricados.

Entre os Wajana tangas ${ }^{29}$ fabricadas em tecido vermelho podem apresentar uma notada variabilidade de acordo com o sexo e a idade da

${ }^{29}$ Esta peça do vestuário é usada também por vários grupos que habitam a região das Guianas, entre eles os grupos indígenas de língua caribe Tiriyó, Aparai, Kaxuyana, Waiwai, além dos Wajãpí, índios de língua Tupi que vivem na região delimitada pelos rios Oiapoque, Jari e Araguari, no Amapá. 
pessoa que usará a peça e a atividade na qual será usada, ou seja, em cerimônias ou no cotidiano (Van Velthem, 2003.).

A tanga masculina é caracterizada por uma faixa retangular que passa entre as pernas e é presa por uma corda de algodão, pendendo na frente. Nas cerimônias, se caracterizam por serem extremamente longas, na frente $e$ atrás, chegando aos tornozelos. Já as tangas usadas cotidianamente são curtas, sobretudo, atrás (ibidem).

Já a tanga feminina é caracterizada por um retângulo de tecido, disposto na frente e preso ao quadril por um fio de algodão, e sobre o qual se usa uma espécie de saiote, adotado mais recentemente. Já as tangas cerimoniais são tecidas com fios de algodão e miçangas e

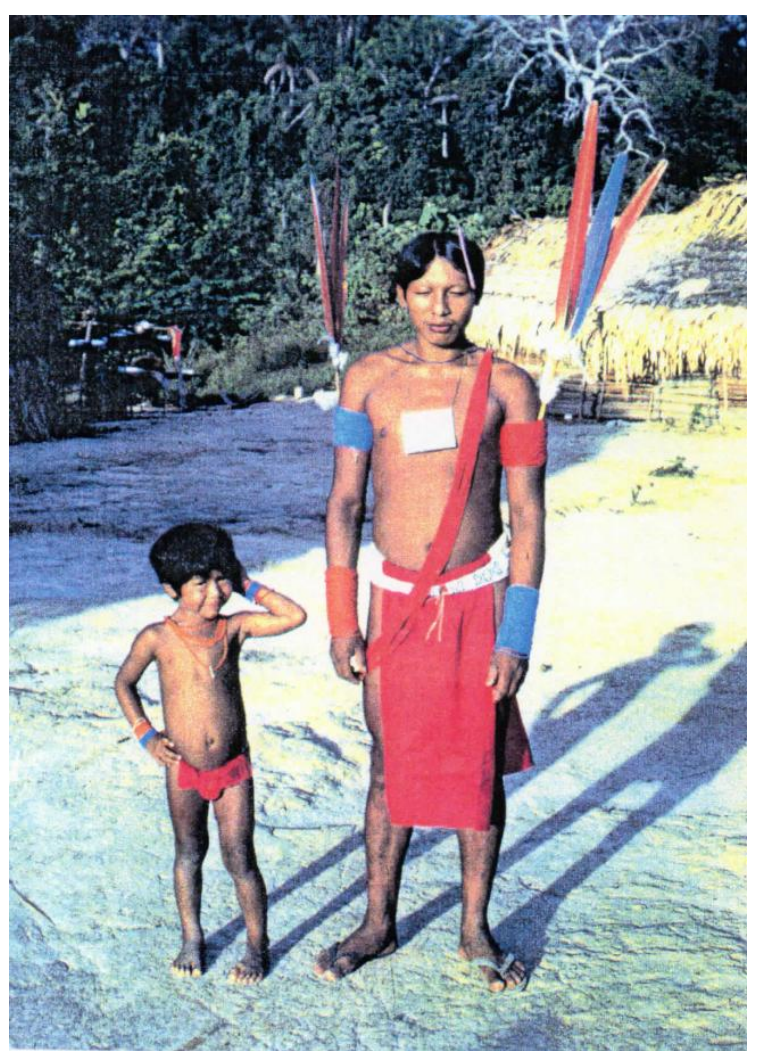

Figura 17. Jovem e criança Wajana trajando tangas masculinas. Destaque para a tanga cerimonial kupime kamisá trajada pelo jovem Fonte: Van Velthem, 1995: 188.

apresentam motivos iconográficos em cores contrastantes. As tangas das crianças, por seu turno, se caracterizam por serem mais estreitas e mais curtas do que aquelas dos adultos (ibidem).

Não estamos sugerindo uma analogia direta entre as tangas cerâmicas marajoara e as tangas de tecido industrial dos Wajana e tampouco sugerindo que os princípios sociais subjacentes à produção deste itens eram os mesmos ou semelhantes, mas sim destacando que no mundo ameríndio muitas variáveis do âmbito social estruturam a fabricação das "coisas", inclusive tangas, refletindo em sua variabilidade.

Para refletir sobre os princípios sociais que podem ter estruturado a variabilidade das tangas cerâmicas marajoara acreditamos que seria necessário um conhecimento bem mais amplo sobre os contextos das peças. Por isto propormos pensar esta variabilidade vista nas tangas, sobretudo aquela relacionada às cores e a forma de trabalhar a superfície com as cores, a 
partir de um importante aspecto do mundo ameríndio que é tangente à produção e ao uso de adornos, vestimentas e pinturas e que, a nosso ver, pode estar por trás da produção e do uso das tangas cerâmicas: a importância conferida à produção e paramentação dos corpos.

Entre as populações ameríndias, no geral, esta importância recai, sobretudo, no uso de diversos adornos, vestimentas, pinturas corporais, corte de cabelos, etc, em variantes relacionadas ao seu uso, seja no cotidiano seja em festas e rituais, itens intimamente relacionados à fabricação e à socialização do corpo e à noção de pessoa (De Paula, op.cit:; Lagrou, 2007; Seeger et tal, 1979; Seeger, 1980; Velthem, op.cit.; Vidal, 1992).

É importante destacar que as tangas estão inseridas dentro de um contexto mais amplo de objetos relacionados à composição e ornamentação corporal que podem ter estado intimamente ligados à fabricação e à socialização do corpo e à noção de pessoa. Neste sentido, além das tangas, outros itens imbricados à pintura e cromatismo, como tintas e potes para tinta, além de ossos com vestígio de pintura vermelha em urnas funerárias (Ferreira Penna, 1877; Meggers e Evans, op.cit.; Palmatary, 1950; Roosevelt, 1991), não são incomuns nos contextos da fase marajoara, o que aponta para a importância da produção corporal, tanto de corpos humanos quanto cerâmicos.

Pouco sabemos sobre a fabricação e uso de pigmentos, mas Carlos Estevão de Oliveira, por exemplo, escavou na década de 1920 algumas urnas funerárias da fase marajoara que possuíam "blocos" de argila vermelha, branca e amarela em seu interior (figura 18). Estes pigmentos podem ter sido usados na pintura das superfícies cerâmicas, entre elas as tangas, dado que são de tonalidades semelhantes à pintura que notamos naquelas.

O pigmento amarelo-alaranjado visto na ilustração 18, por exemplo, é de uma tonalidade muito próxima às tangas amarelo-alaranjadas, mencionadas anteriormente (figura 14b), e que são bastante raras. O uso de tinta amarela na cerâmica marajoara é raro, reduzido a pouquíssimos objetos, como as tangas já citadas. É possível, no entanto, que ele tenha sido misturado com o vermelho para produção de tonalidades de laranja, cor que é comum principalmente em detalhes pintados nas tangas. Entretanto, conforme mencionado anteriormente, não realizamos nenhum tipo de análise dos 
pigmentos usados nas tintas, por isso, no futuro, seria interessante desenvolver análises focadas em sua composição para confirmar.
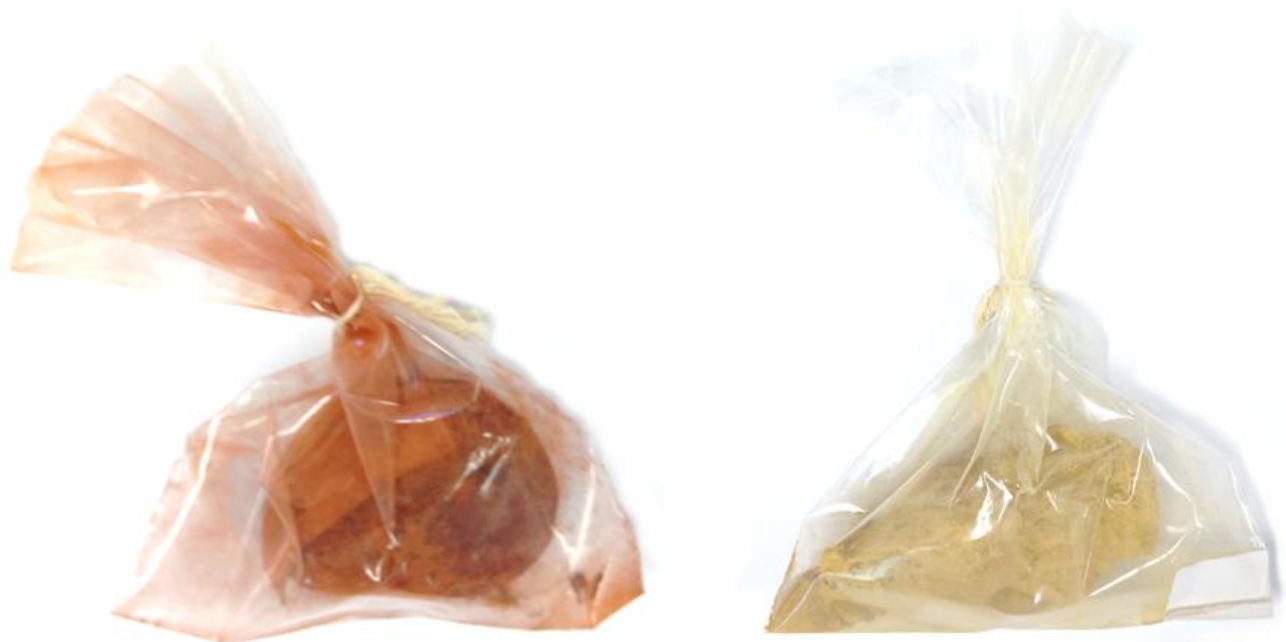

Figura 18: Blocos de pigmentos vermelho e amarelo encontrados em urnas funerárias. Museu do Estado de Pernambuco, Recife. Fotografia: Elvira Blázquez.

Além disto, foram encontrados potes com tinta que pode ter sido usada para a pintura corporal e na cerâmica. Ferreira Penna visitou, em 1873, o sítio Santa $|z a b e|^{30}$ e relata o seguinte

"Foi aqui que eu achei pela primeira vez algumas tinteiras, utensis indispensáveis aos pintores indígenas, todas elas ornadas de elegantes e delicados relevos; e uma contendo boa porção de argila em massa, muito fina, e de côr vermelha, conservando ainda muita humidade (...)" (Ferreira Penna, 1877: 51).

Autores como Palmatary (1950:303) e Roosevelt (1991:63) indicam que um tipo de pote pequeno com orifícios (figura 19), provavelmente para suspensão, que é caracterizado por sua decoração em relevo, e que é relativamente comum nas coleções de cerâmica marajoara, seja o pote de pigmento ou "tinteira" mencionado por Ferreira Penna (op.cit.). Entre os grupos ameríndios em que a fabricação constante da pele é um aspecto esteticamente valorizado, é comum que a pintura do corpo ou de partes dele seja constantemente refeita. Van Velthem (2003: 279), por exemplo, comenta que no passado os homens Wajana usavam colares de pequenas cabaças com pigmentos necessários para a pintura facial cotidiana.

\footnotetext{
${ }^{30}$ Sítio localizado na região do lago Arari.
} 

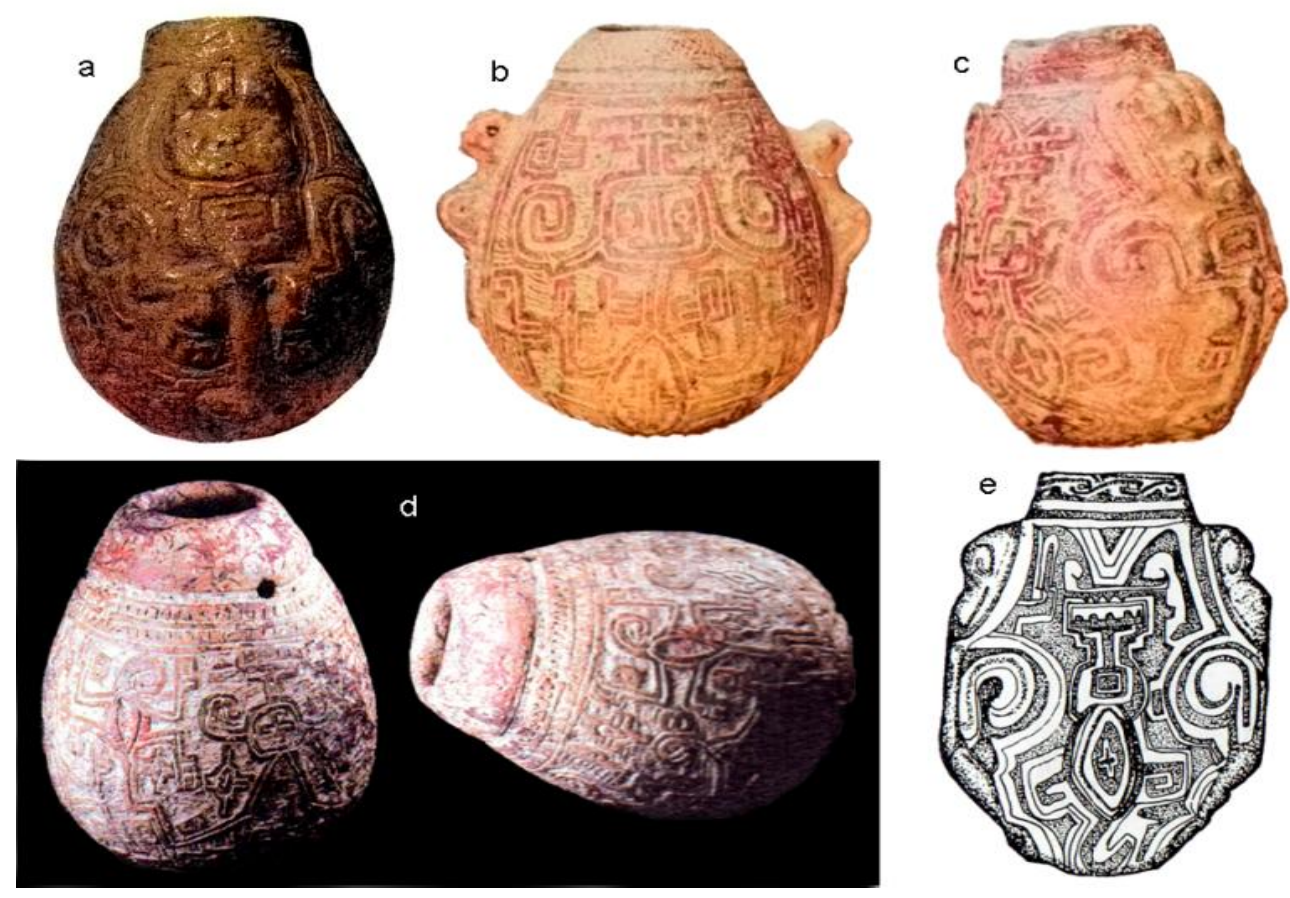

À

vista disto,

Figura 19. "Tinteiras" ou potes para pigmento com orifícios para a suspensão.
a. American Museum of Natural History. Modificado de Roosevelt, 1991:62.
b. American Museum of Natural History. Modificado de Palmatary, 1950: 400.
c, e. Mesmo pote visto sob diferentes ângulos. American Museum of Natural History. C. Modificado de Pamatary, 1950:300. E. Fonte: Roosevelt, 1991:62.
d. Pote visto de diferentes ângulos. Observa-se o detalhe dos orifícios. Museu do Marajó, Cachoeira do Arari. Fonte: Schaan, 2009: 387.

é possível que os pequenos potes "tinteiras" fossem suspensos ao corpo por meio de cordões para que o seu dono ou dona tivesse acesso sempre que preciso às tintas necessárias para a produção e retoque da pintura corporal. É possível, inclusive, que os mesmos grafismos das tangas fossem aplicados aos corpos.

Além destes itens mencionados, as descrições de várias escavações nos sítios da fase marajoara registram uma série de objetos que assim como as tangas e os itens relacionados à pintura dos corpos, estão associados à composição e ornamentação corporal (Schaan, 2004; Barreto, 2009, Ferreira Penna,1877; Meggers e Evans, op.cit.), o que se reflete, inclusive, nas coleções existentes nos museus, que além de tangas cerâmicas, abrangem outros itens, como por exemplo, labretes, botoques, alargadores de orelha, contas de colar em cerâmica e em pedra, encontrados em urnas funerárias, e que apontam para a importância da produção corporal. É importante destacar 
que diferentes motivos de pintura e adornos corporais são vistos também representados nas estatuetas (Schaan, 2001; Barreto, 2017)

Diante do exposto até aqui, percebe-se uma preocupação na composição tanto dos corpos cerâmicos, neste caso específico, as tangas, quanto dos corpos humanos. Tanto as tangas quanto os corpos dos humanos eram pintados e produzidos com tintas e é possível que compartilhassem de decoração semelhante. Além disto, o fato de compartilharem do cromatismo da tinta e, possivelmente, motivos gráficos semelhantes, aponta ao fato de compartilharem também das mesmas substâncias, de técnicas semelhantes de produção.

A etnografia atenta ao fato de que para os ameríndios, em virtude de os objetos serem entendidos como seres corporificados, que constituem corpos ou partes de corpos, e por isto, assim como os humanos, com quem compartilham do antropomorfismo, devem ter a sua "pele" decorada (Lagrou, 2007, 2009; Van Velthem, op.cit.). Humanos e artefatos são decorados com as mesmas técnicas, como no caso dos Wajana cuja técnica da pintura cobre tanto os corpos humanos, como rodas de teto, flechas, utensílios de cabaça e na cerâmica (Van Velthem, op.cit.). Em alguns casos não só a mesma técnica é compartilhada, mas também os mesmos motivos gráficos, como se vê, por exemplo, entre os Asuriní, que utilizam os mesmos grafismos tanto em seus corpos quanto nos corpos cerâmicos (Müller, 1990; 2013).

Barreto (2009) observou na cerâmica marajoara, sobretudo, nas urnas funerárias, uma compulsão que incide na cobertura de cada centímetro das superfícies dos objetos cerâmicos com grafismos extremamente elaborados. Diante do exposto acima, sugerimos que esta mesma compulsão decorativa também se estendesse aos corpos humanos, o que poderia ter sido maximamente expresso, sobretudo, nos contextos cerimoniais, quando os corpos eram cobertos por vários tipos de adornos, pintura corporal e pelas tangas elaboradas com grafismos em várias nuances cromáticas e tangas monocromáticas.

Quanto à variabilidade na decoração das tangas, em nosso entender as diferentes formas de trabalhar o cromatismo, seja por meio de grafismos elaborados em composições cromáticas, seja apenas cobrindo a sua superfície homogeneamente, está relacionada às capacidades que podem ter sido 
atribuídas à tinta em relação à transformação dos corpos e fabricação de certas corporalidades, ou seja, na modulação de certas capacidades. Diante disto, propomos que as tangas com grafismos e monocromáticas podem ter tido eficácia ritual diferente.

No mundo ameríndio, é no contexto ritual que os diferentes tipos de pintura agem conferindo capacidades aos corpos sobre os quais estão aplicados (Lagrou, 2007, 2012, 2013; Müller, 2013; Van Velthem, op.cit.). Em alguns casos, os grafismos constituem uma pele que torna o corpo permeável, sujeito a transformações e metamorfoses, apontando, inclusive, para a transformação da realidade por meio da percepção daquilo que não se vê a olho nu (Lagrou,op.cit.).

Propõe-se então que a agentividade dos dois tipos de tangas poderia se relacionar às suas diferentes capacidades de operar transformações e metamorfoses no campo visual, ou seja, enquanto que as tangas com grafismos atuavam estimulando a visão, as tangas monocromáticas poderiam atuar em um sentido oposto. O que estamos dizendo é que tanto quanto expressam, tintas, pinturas e objetos agem sobre a realidade de maneiras muito específicas (Lagrou, 2007: 51).

Dito isto, no capítulo seguinte nos focaremos na análise iconográfica das tangas tentando compreender os processos pelos quais os grafismos transformam os corpos e estimulam a visão. 


\section{CAPÍTULO 4.}

\section{ANATOMIAS COMPÓSITAS, CORPOS CAMBIANTES}

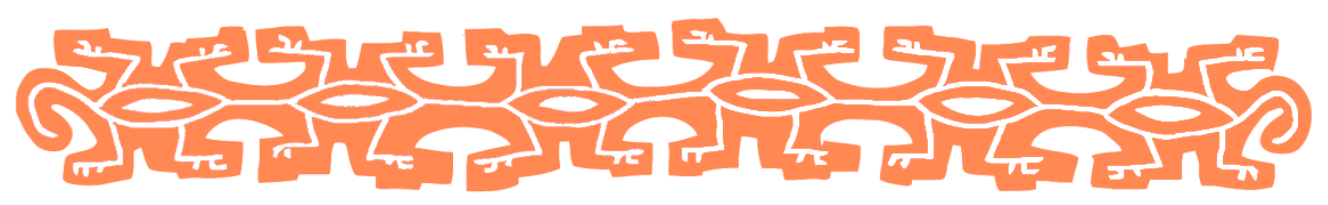

Iniciamos esta dissertação apresentando algumas abordagens sobre a iconografia da cerâmica marajoara, destacando a forma como as imagens foram desmembradas, ora priorizando-se figuras e imagens antropomorfas, ora destacando-se a proeminência de figuras animais, mais especificamente, serpentelíneas, com o intuito de correlacioná-las ao aumento de poder de certos grupos sociais. Em seguida apresentamos as bases teóricas sobre as quais este trabalho está alicerçado, com ênfase especial nos estudos subjacentes à Antropologia da Arte e à Etnologia, que reconhecem nas expressões artísticas ameríndias uma notada transformabilidade das formas que é derivada, fundamentalmente, da captura de agências inimigas e predatórias. No capítulo anterior, nos centramos nos contextos e na variabilidade das tangas, tentando refletir sobre o seu papel na composição e fabricação de corpos humanos, bem como sobre a sua agentividade. Propusemos então que certas características relacionadas à sua variabilidade, como o modo de trabalhar o cromatismo, seja por meio de uma pintura lisa, seja por meio de grafismos, poderiam conferir diferentes agentividades às tangas. Com isto, sugerimos que as tangas com grafismos poderiam transformar a realidade perceptiva.

Neste capítulo nos concentraremos especificamente nas formas de figuração da cerâmica marajoara a partir da iconografia das tangas. Aqui, nos centraremos na análise das tangas com grafismos, tentando explorar as imagens vistas nelas, seja por meio da sua composição, o que inclui aspectos estilísticos e iconográficos, seja por meio dos recursos envolvidos nas experiências sensoriais proporcionadas pelos grafismos. 
Em comparação com a Arqueologia andina, onde determinadas categorias de objetos são estudadas de modo a se compreender dinâmicas sociais e cosmovisões específicas (por exemplo, Golte 2009), na Arqueologia brasileira e, sobretudo, na amazônica, os estudos de categorias específicas de objetos, como por exemplo, as tangas, ainda são poucos (Barreto, 2009; Oliveira, 2016; Prous e Lima, 2011; Prous, 2013; Schaan, 2001, 2003). O foco em determinados objetos possibilita não só a discussão de temas mais específicos, como também sua relação com esferas de análise que atravessam diferentes aspectos das sociedades estudadas, como formas de organização social, identidade social e gênero, entre outros.

No geral, também na Arqueologia brasileira, o estudo de coleções museológicas não é frequente, já que na maioria das vezes foram formadas a partir de coletas e doações, sem controle algum sobre os seus contextos, considerando-se apenas as suas características de conservação e estéticas. No entanto, algumas pesquisas têm aproveitado o potencial destas coleções visando explorar as possíveis relações entre as iconografias dos objetos e as cosmovisões ameríndias (Barreto, 2009; Gomes, 2002; Oliveira, 2016).

Conforme comentado no capítulo anterior, a variabilidade nas formas de ornamentação das tangas sugere diferentes agentividades destes objetos. Diante disto, analisamos as imagens vistas em seus campos gráficos com 0 intuito de verificar as características que lhes conferem as capacidades de abdução e encantamento, nos termos de Gell (1998) priorizando também a identificação dos seus componentes gráficos, quando possível. Com isto, os objetivos da análise são:

1- Identificar os princípios de construção das imagens e o seus principais componentes gráficos.

2- Explorar as características que Ihes conferem agentividade.

3- Apontar os efeitos estéticos e sensoriais dos seus grafismos. 


\section{1. $O$ universo da análise}

Ao longo desta pesquisa analisamos 153 tangas de quatro instituições diferentes, em um total de 08 coleções, e, além disto, incorporamos outras 57, cujas imagens também foram analisadas a partir de várias publicações, abrangendo assim, um total de 210 exemplares nos mais diversos estados de conservação e integridade.

As tangas analisadas abarcam as seguintes instituições e coleções: Museu de Arqueologia e Etnologia, em São Paulo (coleção 006, coleção Plínio Airosa e a coleção do antigo Instituto Cultural Banco Santos), Museu Paraense Emílio Goeldi, Belém (coleção Tombada, coleção Governo do Estado do Pará e a coleção Dita Acatauassu), Museu do Estado de Pernambuco, Recife (coleção Carlos Estevão de Oliveira), Museu Nacional, Rio de Janeiro (coleção Amazônica). As informações sobre estas coleções podem ser melhor vistas na tabela a seguir.

\begin{tabular}{|c|c|c|c|c|}
\hline INSTITUIÇÃO & COLEÇÃO & COLETORES & SÍTIOS & QUANTIDADE \\
\hline MAE-USP & 006 & $\begin{array}{l}\text { Harold Shultz/ Luiz } \\
\text { Paixão Silva/ } \\
\text { Felisberto Camargo }\end{array}$ & $\begin{array}{c}\text { Furinho/ Cuieiras/ } \\
\text { Pacoval/ Pacoval } \\
\text { dos Mello }\end{array}$ & 7 \\
\hline MAE-USP & $\begin{array}{l}\text { ICBS/MAE- } \\
\text { USP }\end{array}$ & $\begin{array}{c}\text { Graciete MCPhee, } \\
\text { Luíz Otavio, Mauricio } \\
\text { Teixeira, Dita } \\
\text { Acatauassu }\end{array}$ & $\begin{array}{l}\text { Teso Camutins, } \\
\text { teso Urubu, Monte } \\
\text { Carmelo }\end{array}$ & 45 \\
\hline MAE-USP & Plínio Airosa & Antonio Paixão Silva & Indeterminado & 1 \\
\hline $\begin{array}{c}\text { Museu } \\
\text { Paraense } \\
\text { Emílio Goeldi }\end{array}$ & $\begin{array}{l}\text { Coleção } \\
\text { Tombada } \\
\text { MPEG }\end{array}$ & Diversos & $\begin{array}{c}\text { Diversos } \\
\text { (Pacoval, teso } \\
\text { Belém, teso } \\
\text { Camutins) } \\
\end{array}$ & 15 \\
\hline $\begin{array}{c}\text { Museu } \\
\text { Paraense } \\
\text { Emílio Goeldi }\end{array}$ & $\begin{array}{l}\text { Governo do } \\
\text { Estado do } \\
\text { Pará }\end{array}$ & Graciete MCPhee & $\begin{array}{l}\text { Teso Belém, teso } \\
\text { Camutins }\end{array}$ & 8 \\
\hline $\begin{array}{c}\text { Museu } \\
\text { Paraense } \\
\text { Emílio Goeldi }\end{array}$ & $\begin{array}{c}\text { Coleção Dita } \\
\text { Acatauassu }\end{array}$ & Dita Acatauassu & Vários & 15 \\
\hline $\begin{array}{c}\text { Museu do } \\
\text { Estado de } \\
\text { Pernambuco }\end{array}$ & $\begin{array}{l}\text { Coleção } \\
\text { Oliveira }\end{array}$ & $\begin{array}{c}\text { Carlos Estevão } \\
\text { Oliveira }\end{array}$ & $\begin{array}{l}\text { Pacoval e } \\
\text { Severino }\end{array}$ & 8 \\
\hline $\begin{array}{l}\text { Museu } \\
\text { Nacional }\end{array}$ & $\begin{array}{l}\text { Coleção } \\
\text { amazônica }\end{array}$ & $\begin{array}{c}\text { Orville Derby, } \\
\text { Ladislau Netto, entre } \\
\text { outros }\end{array}$ & $\begin{array}{c}\text { Pacoval entre } \\
\text { outros }\end{array}$ & 54 \\
\hline
\end{tabular}

Tabela 10. Relação das instituições e coleções de tangas analisadas. 
As coleções do Museu de Arqueologia e Etnologia da Universidade de São Paulo

Esta instituição possui 119 peças divididas em três coleções, sendo 60 com grafismos e 59 monocromáticas, além de 55 fragmentos, sendo que destes 36 são de tangas com grafismos e 16 monocromáticos. Estas peças se encontram em variados estados de preservação e integridade. Em nossa pesquisa priorizamos a análise das tangas com grafismos, sendo que destas 60 tangas com grafismos analisamos 53. É importante destacar também que, apesar de termos analisado os fragmentos, nem sempre foi possível incorporálos aos grupos formados devido às poucas possibilidades de analisar as suas características estruturais.

\section{Coleção 006}

A coleção 006 do MAE-USP é composta por 9 tangas, sendo destas 7 com grafismos (vermelho-sobre branco ou marrom-sobre-branco) e duas monocromáticas (engobo vermelho ou alaranjado), todas em estados variados de conservação e integridade.

Entre estas 7 peças com grafismos 3 estão íntegras e 4 estão incompletas, apresentando ausência de uma ou mais de suas extremidades ou partes do corpo. Destas, uma apresenta perda total de policromia, mantendo na superfície externa somente o engobo branco e na superfície interna, um triângulo de pintura vermelha sobre o engobo branco. Outra peça, além de incompleta, apresenta perda quase total de policromia. Por esta razão não foi possível analisar os grafismos destes dois últimos exemplares. Há ainda nesta coleção 53 fragmentos tanto das extremidades quanto do corpo de tangas. São 36 fragmentos de tangas com grafismos e 16 monocromáticos.

Esta coleção foi formada no Museu Paulista a partir de origens diversas. Muitos itens marajoara desta coleção foram adquiridos pelo Museu Paulista em 1948 da coleção de Luiz Paixão Silva. Entre estes itens estão uma tanga com grafismos proveniente do Pacoval e um fragmento de tanga de procedência indeterminada. 
Segundo os registros depositados na documentação do MAE-USP, em 1985 foram doadas pelo menos 10 peças marajoara ao Museu Paulista por Felisberto Camargo. Entre estas peças estavam 07 vasilhames de tamanhos diversos, uma estatueta-chocalho e duas tangas com grafismos. Destas duas tangas somente uma se encontra hoje na reserva técnica do MAE-USP, da qual a procedência é indeterminada.

A maioria das peças de Marajó desta coleção foi coletada por Harold Schultz, em 1950, e é proveniente de tesos diversos. Entre os itens coletados estão fragmentos cerâmicos diversos, urnas funerárias, vasilhames diversos, estatuetas, contas líticas e tangas cerâmicas. Das 09 tangas da coleção, pelo menos 07 constam no inventário e nas fichas documentais, registrados no Museu Paulista, como coletados por Harald Schultz. Entre estas, três são provenientes do teso Furinhos e uma do teso Cueiras, ambos localizados no conjunto Camutins, no Rio Anajás, uma é proveniente do teso Pacoval do Arari e mais duas do teso Pacoval dos Melo.

Deste material coletado por Schultz, vários itens não estão mais na coleção, pois foram doados ou permutados com outras instituições estrangeiras ainda na época em que estavam depositados no Museu Paulista. Com o Royal Institute Tropical, em Amsterdam, por exemplo, foram permutados fragmentos cerâmicos provenientes do teso Severino e do teso Cuieiras, além de uma tanga do teso Pacoval dos Mello, itens que posteriormente foram transferidos daquela instituição para o Tropen Museum, em Amsterdam.

Uma parte significativa do material marajoara da coleção 006 que foi coletada por Schultz em 1950 é proveniente de escavações realizadas em sítios da fase marajoara entre janeiro e março de 1950. Naquela ocasião uma equipe do Museu Paulista, composta por Harald Schultz e Myrthes Nogueira, e acompanhada por Peter Paul Hilbert, representante na época do Museu Paraense Emílio Goeldi e do antigo Instituto de Antropologia e Etnologia do Pará, exploraram os tesos do Alto Rio Camutins e os tesos do Severino e do Pacoval. Os artefatos arqueológicos, produtos destas escavações, foram enviados ao Museu Paulista (Hilbert, 1952).

As escavações, nos tesos do alto Camutins, foram efetuadas em Furinho e Cuieiras. Em Cueiras foram escavadas vinte urnas funerárias antropozoomórficas com rostos estilizados e olhos salientes, além de urnas 
menores excisas com jacarés modelados, sendo que dentro de uma destas havia sessenta e quatro contas cilíndricas feitas de uma pedra branca com pequenas manchas pretas (Meggers e Evans, 1957:300). Além disto, segundo consta nos inventários da coleção 006, foram escavados materiais associados, como por exemplo, uma urna menor que estava dentro de uma maior e também um apito que estava dentro de uma urna. Já em Furinho foram escavados um botoque cerâmico e cinco tangas, a maioria delas monocromática (Meggers e Evans, op.cit.).

Entre as 4 tangas provenientes destes tesos, existentes atualmente nesta coleção, uma foi escavada em uma urna em Cuieiras (Hilbert, op.cit.), todavia, não foi possível relacionar esta tanga existente a uma urna funerária específica. Das 5 tangas escavadas em Furinho, 2 com grafismos e 3 monocromáticas, só restaram 3 no MAE. As outras 2 possuem paradeiro incerto. É possível que uma delas tenha sido permutada com o Tropen Museum, já que há na coleção deste museu 2 tangas, uma delas obtida por meio de permuta com o museu Paulista. Já a outra não foi possível localizar.

\section{Coleção Plínio Airosa}

Nesta coleção há apenas uma tanga de proveniência incerta. Consta em sua documentação que esta peça pertencia à coleção do etnólogo Antonio Pereira, de Manaus. Posteriormente o colecionador Antonio Paixão Silva a adquiriu, doando mais tarde a Plínio Airosa.

\section{Coleção Instituto Cultural Banco Santos/MAE-USP}

O conjunto analisado desta coleção abrange 45 tangas com grafismos em estados variados de conservação, sendo que várias foram restauradas.

Este acervo foi composto a partir da aquisição de coleções formadas por fazendeiros da ilha do Marajó. No total foram 06 coleções adquiridas, sendo elas as seguintes: Coleção Luiz Otávio, Coleção Graciete, Coleção Dita Acatauassu, Coleção Maurício Teixeira, Coleção Gisela e Coleção Sílvia. Destas, as únicas que possuem tangas são a Coleção Luiz Otávio, Coleção Graciete, Coleção Dita, Coleção Maurício Teixeira, somando um total de 111 
tangas, sendo destas 53 com grafismos e 59 monocromáticas, em vários estados de preservação e integridade.

A coleção Luiz Otávio é composta por cerca de 200 peças, entre elas 79 tangas. Destas 79, hoje no MAE-USP, 62 permanecem catalogadas nesta coleção. As outras 17, durante a transferência para o MAE, como ainda não estavam identificadas foram misturadas com tangas das outras coleções, também não identificadas. Entre estas 62 identificadas, existentes no MAE, 29 apresentam grafismos e 33 são monocromáticas.

A coleção Graciete é composta por 403 peças, entre elas 5 urnas funerárias grandes, 67 urnas ou vasos médios, 8 bancos, 31 tigelas médias e pequenas, 8 pratos, 6 estatuetas, 53 peças entre rodelas de fuso, bodoques e miniaturas de tigelas, um carimbo feito de osso, 5 lâminas de machado, fragmentos cerâmicos diversos e 12 tangas. Destas, apenas 5 permanecem catalogadas nesta coleção no MAE, pelo mesmo problema descrito acima, sendo 4 com grafismos e 1 monocromática.

Tanto a coleção Luiz Otávio quanto a coleção Graciete são provenientes da Fazenda São Marcos, onde estão localizados os tesos Camutins e o teso Urubu, ambos do conjunto conhecido como Os Camutins.

A coleção Maurício Teixeira é composta por 37 peças, entre elas uma urna funerária média, 6 estatuetas, 3 pratos, 6 tigelas, 4 vasos, fragmentos variados e 8 tangas. Destas 8 tangas apenas 3 permanecem catalogadas na coleção, pelo problema já descrito, sendo uma tanga com grafismos e duas vermelhas. Todas as peças desta coleção, com exceção de uma tigela que foi doada por Dita Acatauassu, são provenientes da Fazenda Monte Carmelo, onde se localiza o conjunto de tesos conhecido como Monte Carmelo, composto por três tesos.

A coleção Dita Acatauassu é composta por 45 peças, sendo duas urnas pequenas, 12 vasos e tigelas fundas, 5 pratos, 9 estatuetas fragmentadas, fragmentos diversos e 12 tangas fragmentadas. Destas 12 tangas, seis permanecem catalogadas na coleção, sendo 4 com grafismos e duas monocromáticas. Esta coleção foi formada por Dita Acatauassu a partir de peças coletadas, doadas ou trocadas, provenientes de vários sítios da llha de Marajó, por esta razão é impossível determinar uma procedência destas peças. 


\section{Coleções do Museu Paraense Emílio Goeldi}

As coleções marajoara desta instituição abrangem cerca de 2.000 peças (Amorim, 2010), em vários estados de integridade, formada ao longo de mais de um século, com a incorporação de artefatos oriundos de pesquisas, comodatos e doações, e provenientes de diversos sítios arqueológicos, a maior parte descontextualizada.

\section{Coleção Tombada do Museu Paraense Emílio Goeldi}

O conjunto de tangas analisadas nesta instituição abrange cerca de 15 tangas com grafismos, em diversos estados de integridade e conservação, a maior parte sem informações sobre contextos, algumas provenientes do teso Belém, do conjunto Os Camutins, e outras provenientes do teso Pacoval. É importante salientar que a coleção de tangas deste museu abrange cerca de 39 peças, sendo 20 com grafismos e 19 monocromáticas, além de diversos fragmentos de ambos os tipos.

A coleção desta instituição é composta por urnas funerárias, estatuetas, pratos, tigelas, inaladores, bancos, etc. Aqui, incluem-se as coleções formadas pelas pesquisas de Meggers e Evans (1957), abrangendo algumas urnas funerárias, vasilhas e uma tanga monocromática, pelas pesquisas de Mario Simões, englobando urnas funerárias, vasos e tangas, e pelas pesquisas de Schaan (2004), abarcando urnas, tangas e outros objetos.

\section{Coleção Dita Acatauassu}

Esta coleção integra o acervo do Museu Paraense Emilio Goeldi como parte de um comodato com Governo do Estado do Pará. E assim como aquela que compõe a coleção ICBS/MAE-USP, esta também foi formada por Dita Acatauassu por meio da aquisição de peças provenientes de diversos sítios da ilha de Marajó.

O conjunto analisado soma 15 tangas em diversos estados de integridade e conservação. Estas peças abrangem um conjunto mais amplo composto por 719 objetos, entre urnas funerárias, tigelas, pratos, estatuetas e 
tangas. No total, este acervo é composto por 21 tangas, sendo 16 com grafismos e cinco monocromáticas.

\section{Coleção Governo do Estado do Pará}

Assim, como visto acima, esta coleção também está depositada no Museu Paraense Emílio Goeldi como parte de um comodato com Governo do Estado do Pará, e assim como ocorre com várias peças que compõem o acervo da coleção ICBS/MAE-USP, estas também são provenientes da Fazenda São Marcos, no Rio Camutins.

Foram analisadas 8 tangas com grafismos, de um total de cerca de 14 peças que esta coleção abrange, sendo 10 com grafismos e quatro monocromáticas.

\section{Coleção Oliveira, Museu do Estado de Pernambuco}

A coleção marajoara depositada no Museu do Estado de Pernambuco, em Recife, foi formada por Carlos Estevão de Oliveira a partir de várias escavações realizadas em diversos sítios localizados nas proximidades do Lago Arari, entre 1925 e 1926, como o teso Severino, o teso Pacoval e o teso Ilha dos Bichos. Posteriormente ao seu falecimento, no fim da década de 1940, esta coleção foi doada, a seu pedido, ao museu.

Neste acervo incluem-se urnas funerárias, estatuetas, pratos e tigelas, bancos e 14 tangas, entre monocromáticas e com grafismos. O conjunto analisado nesta instituição abrange oito tangas com grafismos, quatro do teso Severino, duas do teso pacoval e duas de procedência indeterminada, mas que devem ser provenientes de um destes dois tesos.

\section{Museu Nacional}

A coleção marajoara depositada no Museu Nacional, no Rio de Janeiro, é uma das mais antigas, abrangendo peças das primeiras explorações aos sítios da fase marajoara. Muitas das peças do acervo deste museu são provenientes das primeiras explorações aos tesos na década de 1870. No 
entanto, em função das precárias formas de registrar e sistematizar a entrada destes objetos naquela época, não há informação sobre a procedência das peças deste acervo.

A coleção abrange peças provenientes das explorações de Charles F.Hartt, Orville Derby, Ladislau Netto e de Domingos Ferreira Penna aos tesos Pacoval e Camutins, na década de 1870, e das pesquisas de Heloísa Alberto Torres, em 1930, no teso Pacoval do Cururu.

O conjunto de tangas analisadas neste museu é composto por 53 peças, sendo destas 17 inteiras e as demais fragmentadas. É importante destacar que a coleção de tangas desta instituição abrange também seis tangas monocromáticas inteiras, além de 22 fragmentadas, além de diversos fragmentos de ambos os tipos, incluindo 95 fragmentos provenientes das pesquisas de Meggers e Evans (op.cit.).

\section{Coleç̃os diversas}

Além das tangas analisadas nas instituições mencionadas acima, nesta pesquisa incorporamos 57 peças provenientes de diversos museus, instituições e coleções particulares, cujas imagens foram publicadas em livros, catálogos e dissertações (Barbier, 1995; Brito, 2000; Correa e Barry, 2002, 2007; Figueiredo e Folha, 1976; Meggers e Evans, 1957; Mordini, 1929; Nordenskiöld, 1930; Palmatary, 1950; Schaan, 2009; Streiff, 1966; Troufflard, 2010; Young-Sánchez e Schaan, 2011). 


\begin{tabular}{|c|c|c|}
\hline \multicolumn{3}{|c|}{ Tangas de coleções diversas } \\
\hline Coleção/ Instituição & Quantidade & Procedência \\
\hline $\begin{array}{c}\text { Museu do Marajó, Cachoeira do } \\
\text { Arari }\end{array}$ & 8 & Indeterminada \\
\hline $\begin{array}{l}\text { Antiga coleção Instituto Cultural } \\
\text { Banco Santos, São Paulo }\end{array}$ & 2 & $\begin{array}{l}\text { Fazenda São Marcos. Tesos Urubu e } \\
\text { Camutins. } \\
\text { Fazenda Monte Carmelo, tesos do } \\
\text { Monte Carmelo }\end{array}$ \\
\hline $\begin{array}{c}\text { Coleção Montenegro /Museu do } \\
\text { Instituto Histórico e Geográfico de } \\
\text { Alagoas, Maceió }\end{array}$ & 2 & Pacoval \\
\hline $\begin{array}{l}\text { Coleção Governo do Estado do } \\
\text { Pará/ Museu do Forte do Presérpio e } \\
\text { Museu das Gemas, Belém. }\end{array}$ & 8 & $\begin{array}{c}\text { Fazenda São Marcos, Rio Camutins, } \\
\text { Tesos Urubu e Camutins. }\end{array}$ \\
\hline $\begin{array}{c}\text { Museu Rocha Santos, Figueira da } \\
\text { Foz, Portugal }\end{array}$ & 1 & Pacoval \\
\hline $\begin{array}{l}\text { Museu Nacional de Etnologia, } \\
\text { Lisboa }\end{array}$ & 2 & Teso Camutins \\
\hline $\begin{array}{c}\text { American Museum of Natural } \\
\text { History, Nova York }\end{array}$ & 6 & Pacoval \\
\hline $\begin{array}{c}\text { Anthropology Collections of Cornell } \\
\text { University, Ithaca }\end{array}$ & 1 & Pacoval \\
\hline Denver Art Museum, Denver & 3 & Indeterminada \\
\hline $\begin{array}{l}\text { National Museum of American } \\
\text { Indian, Washington e Nova York }\end{array}$ & 5 & Pacoval, Camutins \\
\hline $\begin{array}{c}\text { Peabody Museum of Archaeology } \\
\text { and Ethnology, Cambridge }\end{array}$ & 1 & Pacoval \\
\hline $\begin{array}{c}\text { Antiga Coleção Barbier Mueller, } \\
\text { Geneva }\end{array}$ & 2 & Indeterminado \\
\hline $\begin{array}{c}\text { Antiga Coleção Jean Eugéne Lyon, } \\
\text { Geneva }\end{array}$ & 11 & Indeterminado \\
\hline Museum für Volkerkunder, Berlin & 1 & Pacoval \\
\hline $\begin{array}{l}\text { Musée d'ethnographie de Genève, } \\
\text { Geneva. }\end{array}$ & 2 & Indeterminado \\
\hline $\begin{array}{l}\text { Museum of Archaeology and } \\
\text { Ethnology, Cambridge }\end{array}$ & 1 & Pacoval \\
\hline TOTAL & 57 & \\
\hline
\end{tabular}




\subsection{Caminhos para a análise dos campos gráficos e dos grafismos}

Em contextos onde as análises iconográficas estão mais desenvolvidas, como na Arqueologia andina, se tem verificado que os campos gráficos de imagens segmentadas possuem certas relações estruturais. Ali, a divisão dos objetos em campos gráficos ou áreas específicas apontaria para uma cosmovisão onde o cosmo é verticalmente estruturado (Golte, 2009). Analogamente, a etnografia também mostra que entre certos grupos ameríndios a divisão da imagem não visa desassociar as suas partes, mas apontar para as suas relações. Entre os Shipibo-Conibo, por exemplo, as divisões e os tipos de desenhos vistos no Chomu indicam e indiciam regiões específicas do cosmos e os seres que nelas habitam vistos pelo xamã durante o transe alucinógeno (Illius, 1994).

Neste trabalho, inicialmente, por uma necessidade metodológica, abordaremos as tangas a partir dos seus campos gráficos, de modo a mapear seus aspectos estruturais e variáveis para que as especificidades de cada um sejam vislumbradas. Entendemos que apesar de haver uma tendência a seccionar as imagens das tangas em campos decorativos (Schaan, 2001, Prous e Lima 2011), estes campos não devem ser tratados de maneira isolada, mas como partes específicas de um todo abrangido por uma única imagem. Destacamos ainda que as partes que constituem um todo podem apresentar relações que não, necessariamente, necessitam ser gráficas, mas podem ser relações pautadas em uma lógica estruturada a partir de conceitos ontológicos específicos.

Tendo especificado este ponto, sublinhamos que aqui entendemos campo gráfico como a área onde um motivo gráfico é aplicado (Barreto, Lima, Betancourt, 2016; Scatamacchia, et al, 1991; Shepard, 1956) e que pode ser delimitada por um marco caracterizado por linhas ou faixas. Assumimos como motivo gráfico um arranjo particular de elementos distintos, cuja combinação e disposição formam um padrão gráfico (Barreto, Lima, Betancourt, op.cit.).

Shepard (op.cit.) desenvolveu uma abordagem voltada para a análise e descrição sistemáticas dos grafismos das cerâmicas arqueológicas que privilegia aspectos formais como a sua adaptação à forma do suporte, composição ou estrutura, uso de elementos e motivos e características como 
simetria, etc. Tais aspectos poderiam ser utilizados, por exemplo, em análises visando à definição de estilos ou microestilos específicos, mas também poderiam ser usados para avançar o conhecimento sobre culturas especificas, o que poderia abrir caminho para análises dos aspectos simbólicos dos grafismos.

Para Shepard (op.cit.), priorizar os aspectos formais dos grafismos não significa negar a existência de relações entre o aspecto formal e o aspecto simbólico, mas mostra que existe a necessidade de usar diferentes métodos de estudo para cada um. Por esta razão, ao mesmo tempo que nos apoiamos em alguns aspectos da abordagem desta autora também achamos útil, para entender a agentividade destes grafismos, a proposta de Gell (op.cit.), descrita mais à frente. Dito isto, elencamos a seguir alguns pontos de Shepard (op.cit.) útil para a nossa análise.

A estrutura dos campos gráficos, para esta autora, diz respeito ao plano aparente, às principais divisões espaciais, e à relação das partes que compõem o campo. Para a análise das tangas tais sugestões parecem razoavelmente aplicáveis, uma vez que estas são constituídas por campos gráficos bem delimitados e, com isto, as suas especificidades podem ser melhor vislumbradas de modo a revelar recorrências estruturais.

Nesta abordagem, o primeiro passo a ser dado é a identificação das delimitações e divisões estruturais primárias do campo gráfico com o intuito de verificar os métodos de composição. É comum, nos grafismos, que o procedimento da oleira ao delinear e tratar o espaço envolva a elaboração de linhas, a divisão e a subdivisão do campo ou a composição do campo com a repetição de um motivo por meio de movimentos simétricos.

Estreitamente relacionada à análise da estrutura dos grafismos está a análise da simetria e dos movimentos simétricos. Para tanto, Shepard (op.cit.) propõe também a sua classificação com base em três classes de simetrias, a simetria bilateral, a simetria rotacional e a simetria radial. A simetria bilateral é caracterizada pelo espelhamento; na rotacional há um ponto de rotação em torno de um mesmo número de repetições dentro de uma revolução; a simetria radial combina reflexão e rotação. Para a classificação da simetria, contudo, é necessária a identificação da parte básica e do movimento pelo qual ela é 
repetida, ou seja, a única parte a partir da qual toda a composição pode ser obtida pela repetição regular de um elemento ou motivo.

Destacamos que certos campos gráficos vistos nas tangas correspondem ao tipo de campo que Shepard (op.cit.) denominou de banda. Esta autora denominou os grafismos deste campo de padrões de banda, que são formados a partir da repetição de um elemento gráfico, ao longo de uma linha reta, por uma série de movimentos como translação, reflexão longitudinal ou horizontal, reflexão transversal ou vertical, rotação dupla, reflexões longitudinal e transversal combinadas, reflexão deslizante ou movimento de parafuso e rotação e reflexão transversal alternadas.

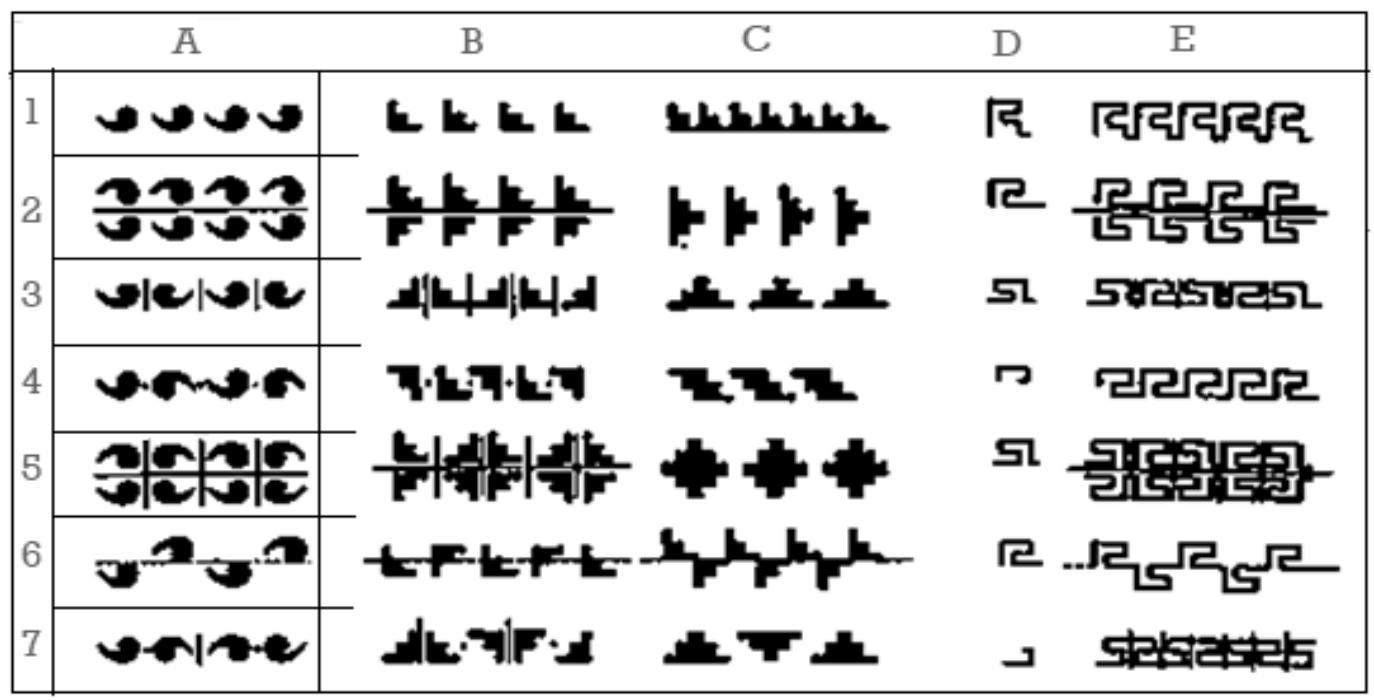

Figura 20- Classes de padrões de bandas formadas a partir de movimentos simétricos. Fonte: Sherpard, 1956.

Gell (op.cit.), ao modo de Shepard (op.cit.), identificou certos movimentos pelos quais os grafismos são repetidos. Entretanto, aqui, diferentemente daquela abordagem, os movimentos simétricos não são usados especificamente para classificar estilos diferentes, mas sim para entender a formação de determinados tipos de padrões e os efeitos visuais que eles provocam. A abordagem de Gell se volta aos aspectos que podem ser entendidos como a fonte de animação dos grafismos, o que estaria contido na cadência gerada pelos quatro movimentos básicos: reflexão, translação, rotação e reflexão deslizante. 
Todos estes movimentos estão intrinsecamente relacionados à formação daquilo que Gell chamou de padrões complexos. Estes padrões agiriam como armadilhas que atraem e prendem o olhar e a mente do espectador em seus emaranhados gráficos, de modo a deixá-lo capturado nas suas "tramas", experiência esta que poderia gerar uma espécie de frustração prazerosa, mas que possibilitaria a ele uma maneira de se relacionar com o objeto recoberto pelos grafismos. Por esta razão são considerados padrões labirínticos, pois capturam o olhar e o observador se prende nele como em um

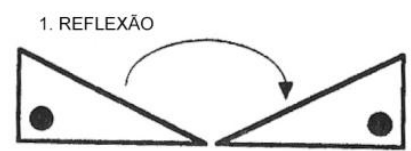

3. ROTAÇÃO

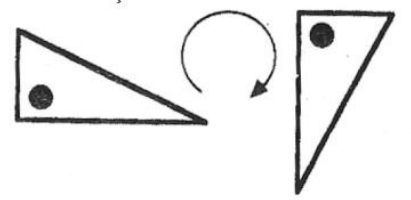

2.TRANSLAÇÃo

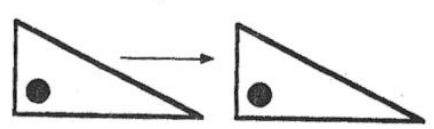
4.REFLEXĀO DESLIZANTE

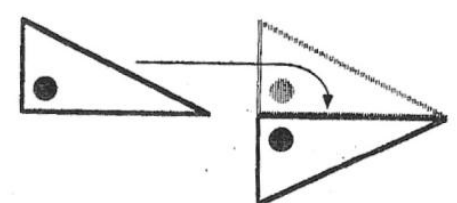

Figura 21. Movimentos empregados na formação dos padrões complexos. Fonte: Gell, 1998. labirinto (Gell, 1998: 79-80).

Importante também para a estruturação dos campos gráficos das tangas é o princípio da representação desdobrada. Este princípio foi primeiramente descrito por Boas (1996 [1928]) em sua análise da arte dos povos ameríndios da costa noroeste da América do Norte e, basicamente, consiste em uma forma de representar figuras tridimensionais em superfícies bidimensionais, cortandoas e encaixando-a sobre uma superfície plana, resultando em uma imagem composta por dois perfis unidos pela cabeça, vistas de frente e "sem costas". Este princípio pode ser acompanhado também do deslocamento do tema que é a distorção ou estilização dos corpos figurados para que se adaptem à superfície (Boas, op.cit.; Levi-Strauss, 2008[1958]).

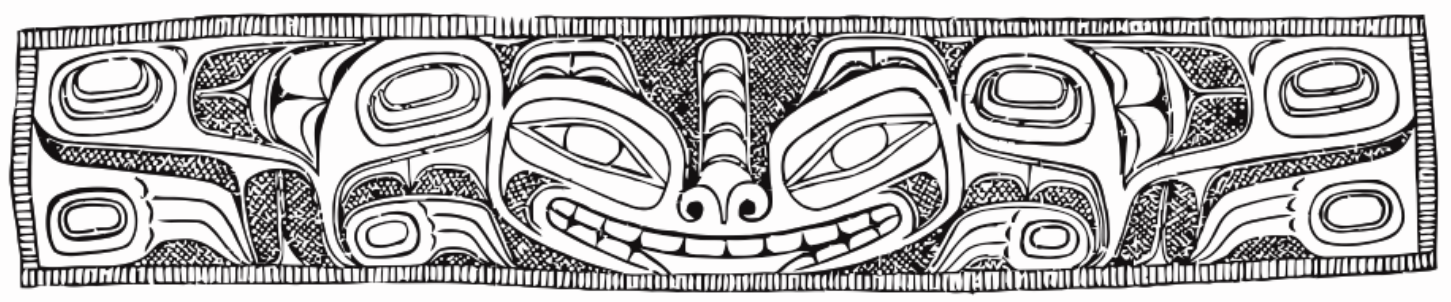

Figura 22. Figura de urso em um bracelete de prata Haida composta pela união de dois perfis. Fonte: Covarrubias, 1961:43.

Para se ter uma ideia, na arte dos ameríndios da costa noroeste, o desdobramento é caracterizado pelo corte longitudinal do animal, da cabeça à 
cauda, de modo que os perfis se juntam no meio, ou ainda uma cabeça pode ser vista de frente apresentando dois perfis do corpo lateralmente (Boas, 1996).

Levi-Straus (2008 [1958]) identificou na pintura facial Kadiwéu um tipo de desdobramento composto por dois motivos. Neste caso, a imagem é construída simetricamente em relação a dois eixos, um vertical no centro da face e o outro horizontal, na altura dos olhos, que se cruzam na base do nariz, dividindo o rosto em quatro setores triangulares, dois superiores e dois inferiores, que são posteriormente elaborados com motivos que se repetem invertidos no triângulo oposto.

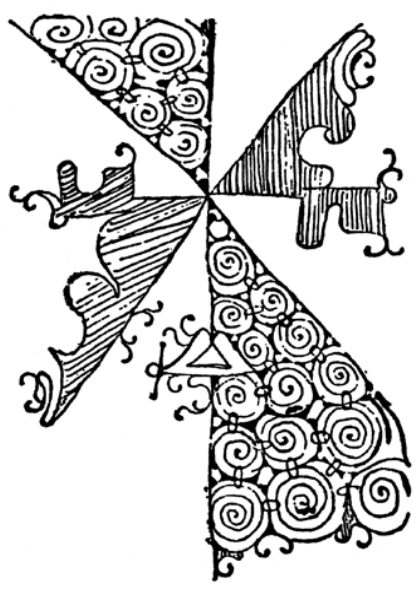

No entanto, a composição destas pinturas em torno destes eixos perpendiculares estrutura o rosto por meio de um procedimento de desdobramento "redobrado", uma vez que o rosto não é recomposto

Figura 23. Desenho Kadiwéu sobre papel replicando a pintura facial que é construída por dois motivos invertidos ao longo de dois eixos de simetria. em dois perfis, mas em quatro quartos, o que está intimamente relacionado ao deslocamento. Aqui, a aparente assimetria que este desdobramento engendra, possui a função formal de garantir a distinção dos quartos, que se confundiriam em dois perfis se os campos se repetissem simetricamente ao invés de se oporem pelo vértice.

$\mathrm{Na}$ Arqueologia, este princípio tem sido empregado enquanto uma ferramenta analítica para a caracterização dos componentes iconográficos das cerâmicas pré-coloniais, permitindo identificar o modo como as diferentes partes das imagens se articulam (Barreto, 2009; Oliveira, 2016).
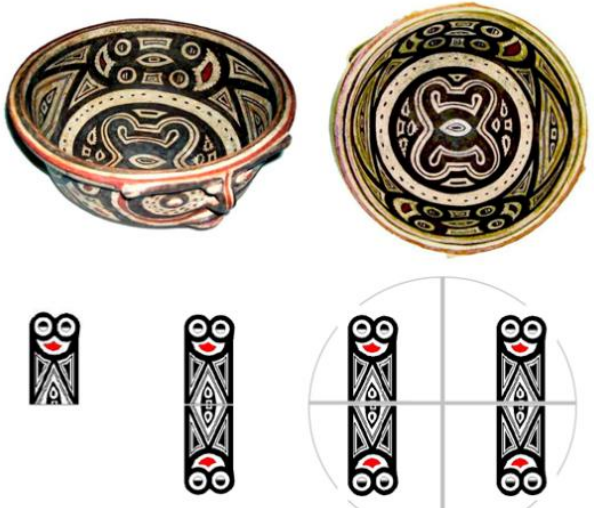

Especificamente no

material marajoara, Barreto (op.cit.) observou que em certas vasilhas e urnas funerárias os campos gráficos são estruturados por um desdobramento a partir de dois eixos de simetria perpendiculares que torna possível
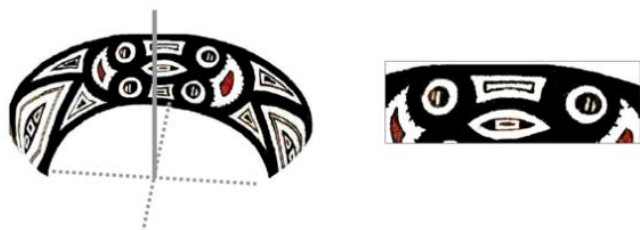

Figura 24. Tigela com grafismos desdobrados. Coleção ICBS-MAE, Museu de Arqueologia e Etnologia, São Paulo. Fonte: Barreto, 2009. 
a percepção de várias figuras (figura 24). Algumas delas, por exemplo, possuem em suas paredes laterais internas uma figura desdobrada ao longo de um eixo de simetria horizontal e que é reunida compondo um corpo losangular com duas cabeças (Barreto, 2009:150). Esta figura é espelhada horizontalmente nas paredes laterais das duas metades internas da vasilha, e são encadeadas por certos elementos que quando justapostos às figuras que aludem a cabeças criam uma cabeça intermediárias entre elas.

Este príncipio se aplica também às tangas, em cuja construção das imagens, inúmeras vezes, as figuras são duplicadas por meio do dedobramento a partir de um eixo vertical, criando uma nova figura, como é possível observar na figura 25. Além disto, outros tipos de desdobramento ocorrem, mas voltaremos a eles no decorrer deste capítulo.

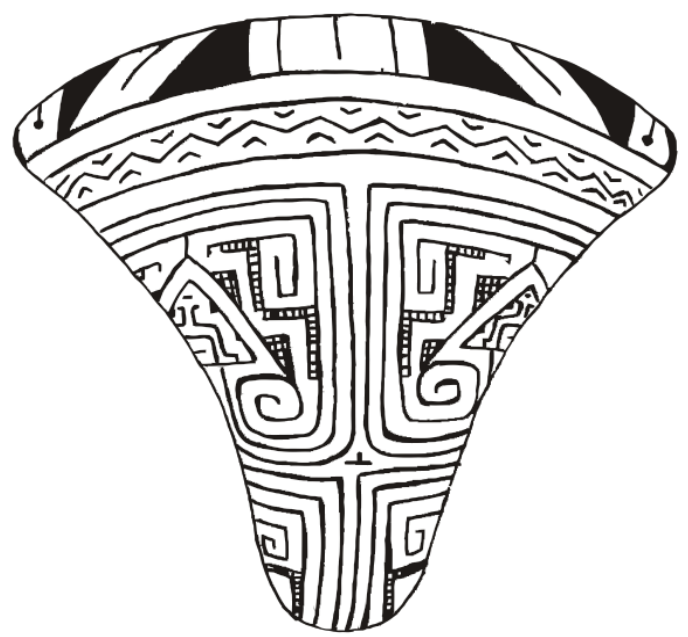

Figura 25. Imagem composta na tanga por meio do desdobramento a partir de um eixo horizontal.

A seguir apresentaremos algumas características estruturais das imagens figuradas nas tangas para depois adentrarmos em suas características iconográficas mais gerais. Posteriormente, descreveremos os conjuntos formados com base nestas características estruturais e iconográficas.

\subsubsection{Os campos gráficos}

Embora alguns estudos atribuam uma repartição tripartite às tangas (Evans e Meggers,1957; Schaan, 2001), a nossa análise mostrou uma 
tendência um pouco mais diversa. Conforme pode ser visto na tabela abaixo, de uma amostra de 210 tangas analisadas, 43,8\% apresentaram 4 campos gráficos, 22,4\% apresentaram 3 campos gráficos, $8 \%$ apresentaram 2 campos e 7,1\% apenas 1 campo. Tangas com mais de quatro campos gráficos correspondem a uma parcela ínfima da amostra, em um total de 2,4\%, ou seja, 5 tangas. Salientamos também que em 34 tangas, ou seja, 16,2\%, não tivemos como determinar a quantidade total de campos devido à ausência de sua porção inferior. Destas, em 27, três campos eram visíveis, sendo destes três, duas faixas superiores e parte do painel gráfico, já em 07 havia apenas dois campos visíveis, que variavam em função da área fragmentada.

\begin{tabular}{|c|c|c|c|c|c|c|c|c|c|c|}
\hline \multicolumn{11}{|c|}{ Variação do número de campos gráficos } \\
\hline \multirow{3}{*}{ 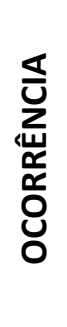 } & $\begin{array}{l}\text { N.o de } \\
\text { campos } \\
\text { gráficos }\end{array}$ & 1 & 2 & 3 & 4 & 5 & 6 & 7 & Indeterminado & Total \\
\hline & $\begin{array}{l}\text { N.o de } \\
\text { tangas }\end{array}$ & 15 & 17 & 47 & 92 & 4 & 0 & 1 & 34 & 210 \\
\hline & $\%$ & 7,1 & 8,0 & 22,4 & 43,8 & 1,9 & 0 & 0,5 & 16,2 & 100 \\
\hline
\end{tabular}

Tabela 11. Variação da quantidade de campos gráficos

A superfície externa das tangas é dividida por linhas contínuas estruturais delimitando assim os diferentes campos gráficos. Observamos que em $81 \%$ das tangas, ou seja, 171, há duas bandas delimitadas por linhas horizontais em sua porção superior, enquanto que a ocorrência de apenas uma banda é reduzida a $8 \%$ da amostra, ou seja, 17 tangas. Abaixo destas bandas, em todas as 210 tangas analisadas, há um campo maior que chamamos aqui de painel gráfico, e que representa uma composição mais complexa de elementos gráficos e motivos. Em um número reduzido a $7,1 \%$ da amostra, a dizer, 15 tangas, não há bandas delimitadas na porção superior, mas apenas 0 painel gráfico.

A altura do painel gráfico na superfície externa da tanga pode ser variável. Assim, com base na recorrência destas bandas e painel gráfico 
definimos quatro áreas mais frequentes que chamamos de banda 1, banda 2, painel gráfico e linhas.

Logo abaixo do painel gráfico, localizado junto à extremidade inferior, é comum que haja linhas simples, duplas, às vezes reticuladas, que podem ser horizontais, verticais e às vezes, flexionadas. Em $46 \%$ das

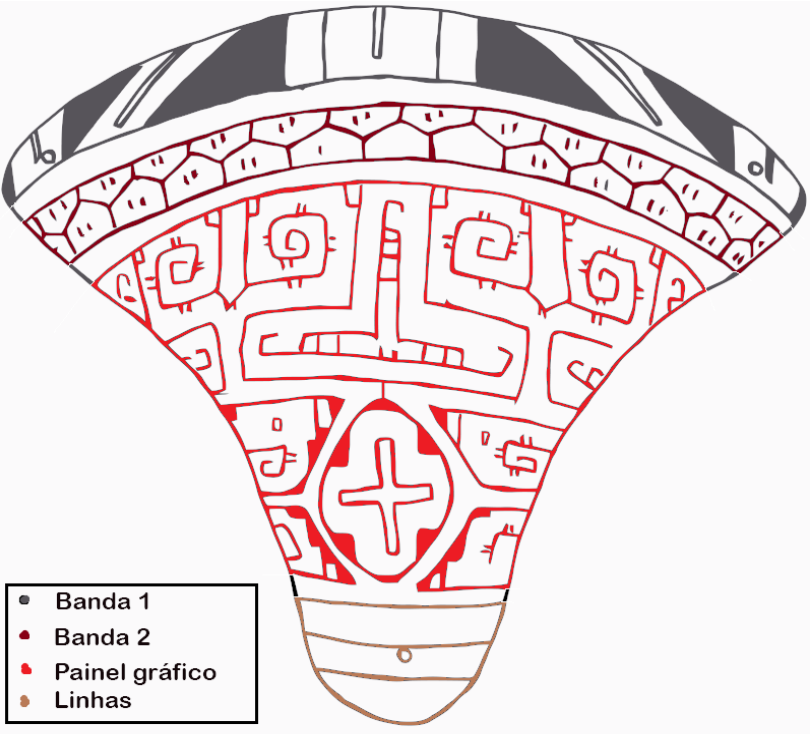
tangas analisadas, ou seja, 97 peças, este campo estava

Figura 26 - Delimitação dos campos gráficos das tangas. presente, enquanto que em $37,6 \%$, isto é, em 79 tangas, ele não existia. É importante também comentar que em $16,2 \%$ da amostra não tivemos como determinar se este campo existia ou não em função da fragmentação da porção inferior das tangas.

\section{A banda 1}

$\mathrm{Na}$ primeira das bandas, localizada na porção superior e mais larga da tanga, o padrão mais recorrente é o que chamamos de padrão 1, que é composto por cinco faixas brancas, alternadamente verticais e oblíquas, formadas pela justaposição de triângulos ou trapézios preenchidos por tinta vermelha ou marrom ou ainda por retículas. A parte central da composição sempre é ocupada por um retângulo branco, ao qual convergem estas faixas laterais. Estas áreas brancas são subdivididas por duas linhas verticais. Todas estas áreas brancas, incluindo o retângulo central, possuem no seu centro uma linha simples ou dupla em "U”.

Este padrão de banda está presente em 175 das tangas que analisamos, ou seja, em 83,3\% da amostra. Há 3 variantes deste padrão, conforme mostra a ilustração abaixo. A variante "A" aparece em $71 \%$ dos casos, ou seja, é a mais frequente, compondo 149 tangas. Já a variante "B" compõe $9,5 \%$ da amostra, tendo aparecido em 20 tangas. A variante "C", por 
seu turno, é a mais incomum, e compõe uma parte muito pequena da amostra, estando presente em 3 tangas (figura 27).
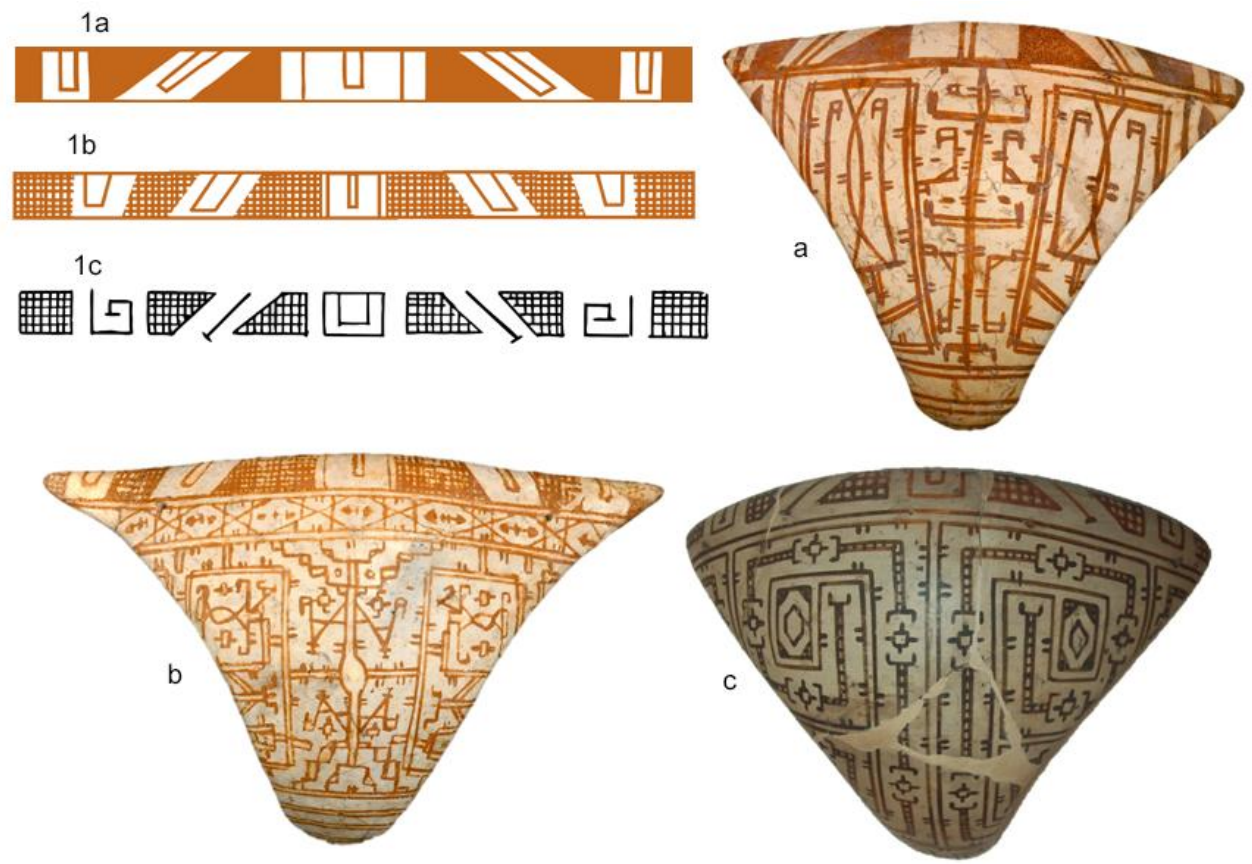

Figura 27- Padrão mais frequente na banda 1 e as suas variantes.

a, b. ICBS/ MAE-USP, Museu de Arqueologia e Etnologia, São Paulo.

c: Museu de Arqueologia e Etnologia, São Paulo.

Somente 15 tangas apresentaram outros tipos de padrões na banda 1 , ou seja, $7,1 \%$, do total ( Figura 28). Destas 15 tangas, 3 apresentaram 0 padrão 2; o padrão 3 apareceu só em uma tanga; o padrão 4 ocorreu em 4 tangas, o padrão 5 ocorreu

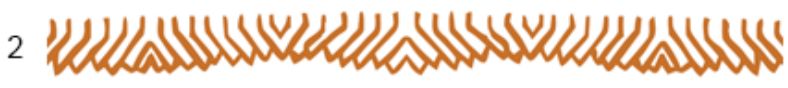
em 6 tangas e o padrão 6 somente Figura 28 - Padrão da banda 1 menos recorrentes. em uma tanga. Observamos que a ocorrência destes padrões é mais comum quando não há uma segunda banda. Destas 15 tangas que apresentaram estes padrões, 13 possuem apenas a banda superior. Nisto, é muito interessante notar que todas as vezes que os padrões 4 e 5 ocorrem eles estão na única banda da tanga. Analogamente, a variante "B" do padrão 1 (Figura 27.1b), em todas as suas 20 ocorrências, integravam a única banda das tangas. 
Barreto (2009) percebeu um tipo de padrão composto por figuras geométricas, visto na borda de certas urnas funerárias, bastante semelhante com aquele padrão 1 de banda mais recorrente nas tangas. Nas urnas funerárias este padrão sintetizaria toda a composição da urna e de seus elementos estruturais e ajudaria na estruturação e organização simétrica dos desenhos no restante do corpo da urna.

Nas tangas, especificamente, não parece que este padrão tenha uma função estruturante, já que há casos onde ele não ocorre, como visto nas tangas que não possuem as duas bandas ou mesmo naquelas onde o padrão do tipo 1 é substituído por outro tipo.

\section{A banda 2}

A banda 2, localizada logo abaixo da primeira e separada dela por uma faixa estreita da cor do engobo, por sua vez, é composta por padrões variáveis com a combinação de elementos geometrizados e estilizados, como triângulos, elementos cruciformes, linhas, quadriláteros, etc, e repetidos linearmente por meio de movimentos simétricos. Há uma gama limitada de movimentos envolvidos na formação destes padrões, como reflexão, reflexão deslizante, translação e rotação, além das combinações destes, mas sempre no sentido horizontal da banda.

Observamos que muitos destes padrões de bandas, no geral, replicam os mesmos modelos, mas com pequenas variações. Assim, há uma ampla gama de padrões semelhantes entre si, e que compartilham a mesma estrutura, mas que são elaborados com elementos gráficos diferentes; ou podem ser trabalhados graficamente de modos diferentes, como por exemplo, entre as variantes, temos elementos semelhantes que podem ser integralmente preenchidos por tinta ou podem ser vazados criando figuras em negativo (figura 30).

A fim de facilitar a descrição dos campos gráficos agrupamos estes padrões em três conjuntos, de acordo com o modelo que replicam.

Padrões do tipo 1. Estes padrões possuem a mesma estrutura básica, composta por triângulos elaborados com figuras em $T$ em negativo em seu interior, ou somente preenchido por tinta, e espelhados em $\mathrm{X}$ e replicados ao 
longo da banda por meio da reflexão, criando um espaço hexagonal entre um e outro, onde são dispostos elementos diversos.

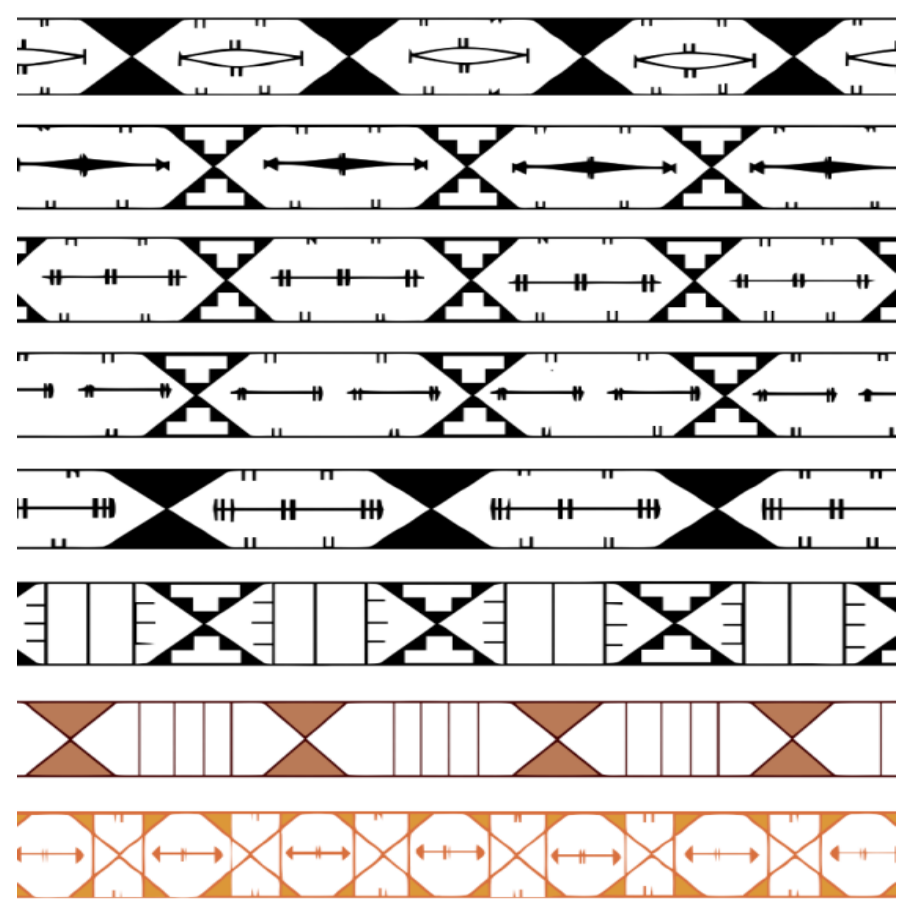

Figura 29. Padrões da banda 2 do tipo 1. Padrões compostos por triângulos espelhados nos vértices.
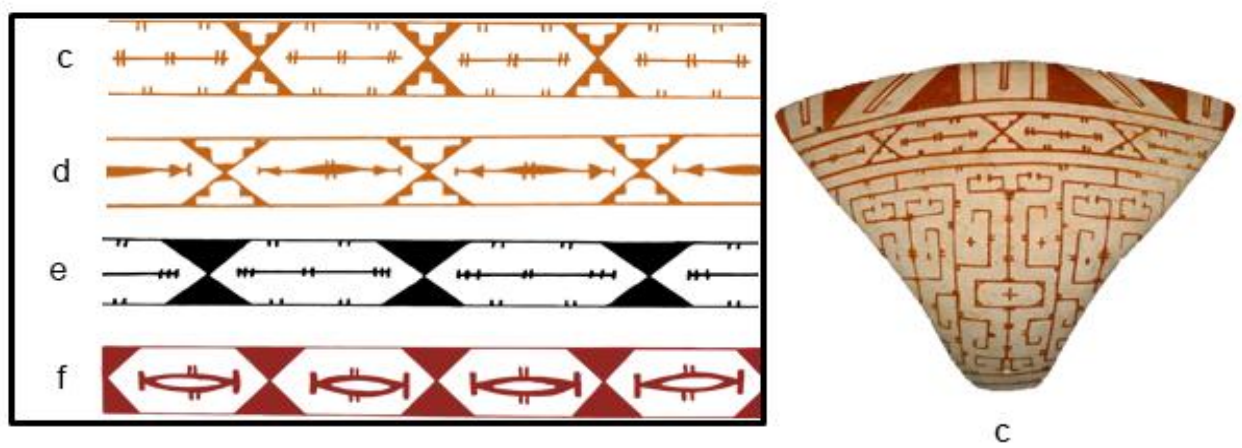

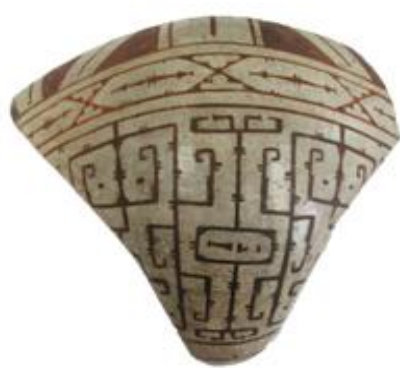

d

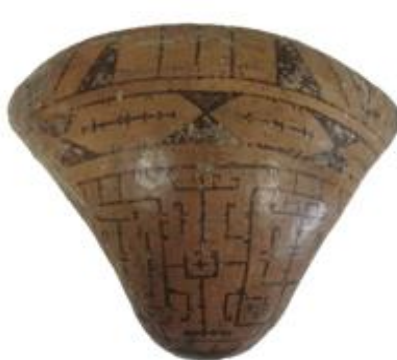

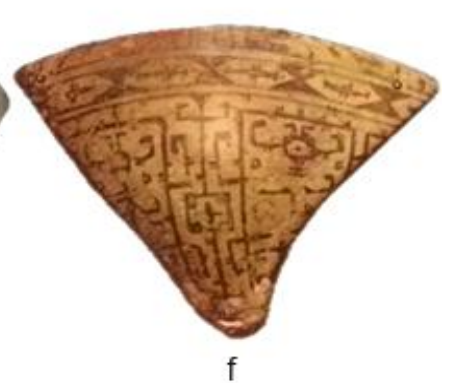

Figura 30 - Variantes do padrão tipo 1. c: ICBS/MAE-USP; d, e: Museu Nacional; f: American Museum of Natural History. Fonte: Palmatary, 1950. 
Padrões do tipo 2. Este grupo de padrões é composto por motivos que apresentam certas recorrências estruturais e gráficas, como por exemplo, a repetição de triângulos, na maioria das vezes, elaborados com figuras de T em seu interior, linhas duplas, etc., espelhados verticamente por meio da reflexão deslizante, o que cria um desenho negativo em ziguezague que, às vezes, pode apresentar também uma linha em ziguezague sobreposta.

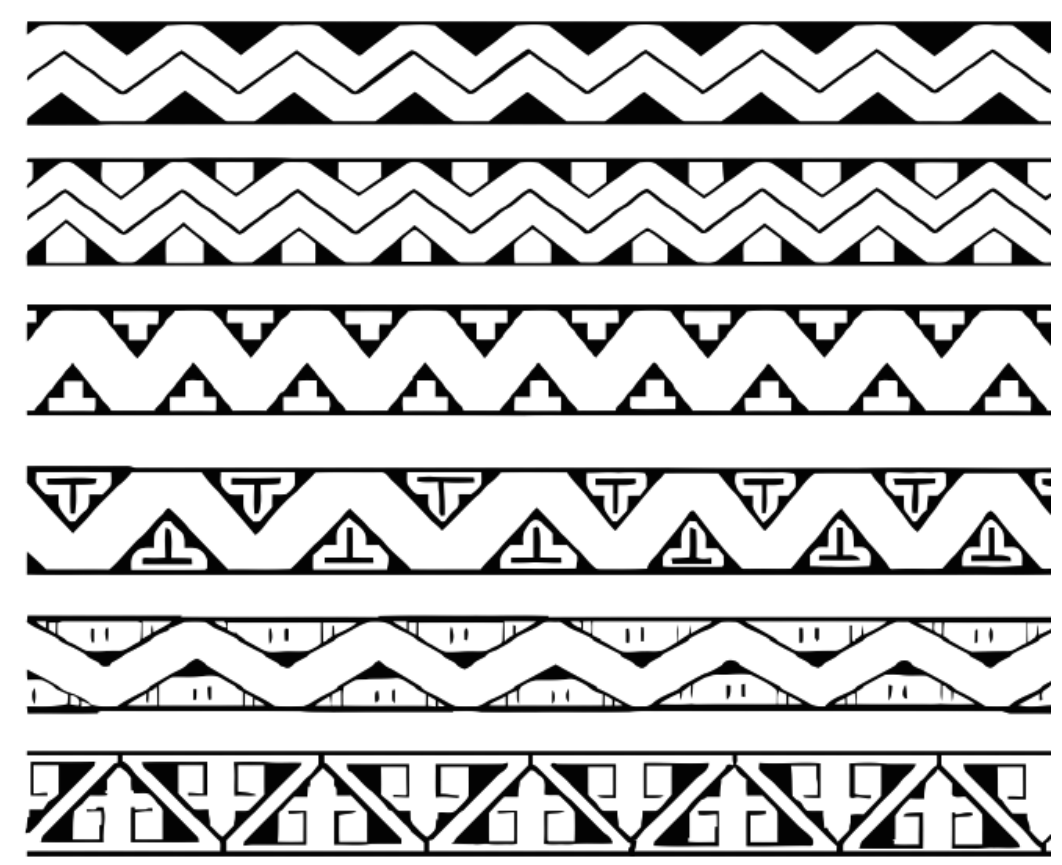

Figura 31. Padrões da banda 2 do tipo 2 compostos por triângulos replicados por meio da reflexão deslizante.

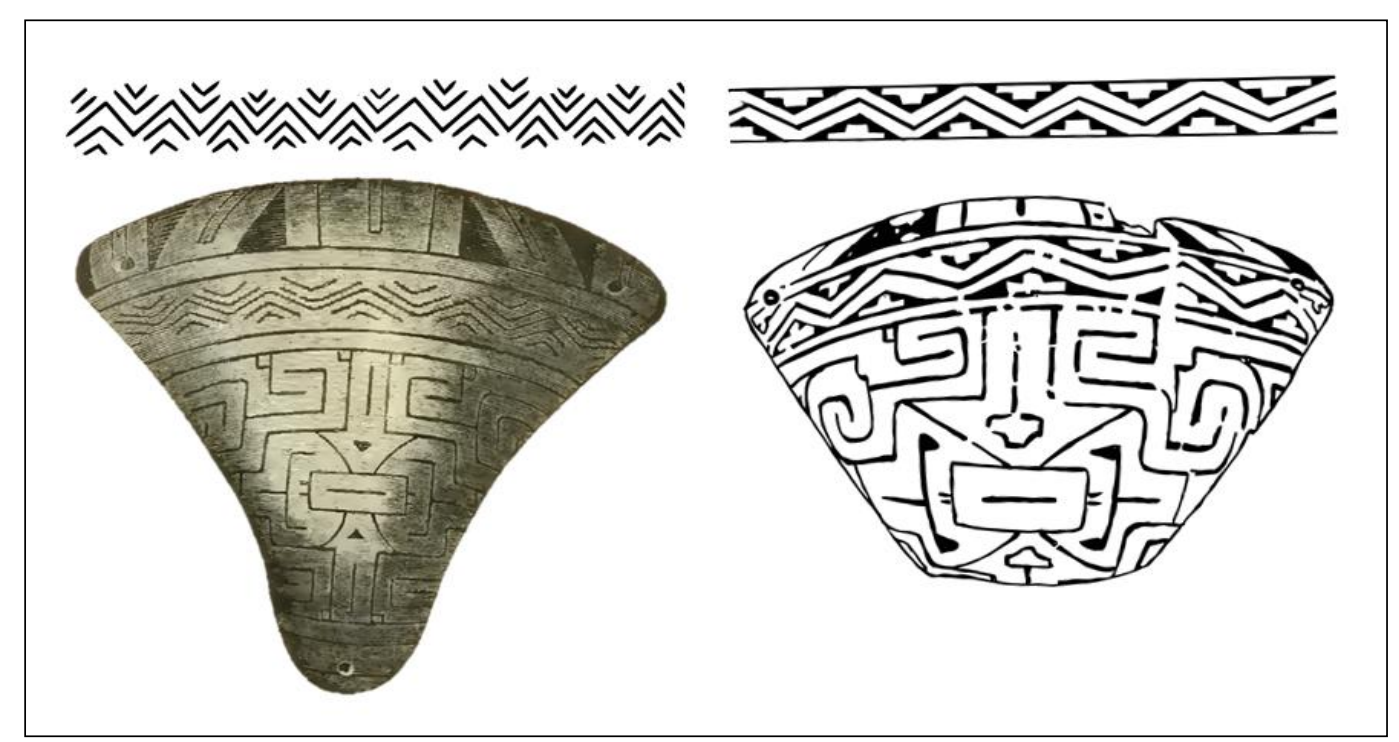

Figura 32. Algumas variantes do padrão 2 em tangas . Esquerda: Museu Nacional, Rio de Janeiro. Fonte: Netto, 1885. Direita: Museu Paraense Emílio Goeldi, Belém. 
Padrões do tipo 3. Este padrão é o menos recorrente tendo a sua presença limitada a certas tangas. É composto por elementos em forma de pentágono com linhas duplas em seu interior que são replicados por meio da reflexão deslizante, formando um padrão que Shepard (op.cit.) caracterizou como allover.

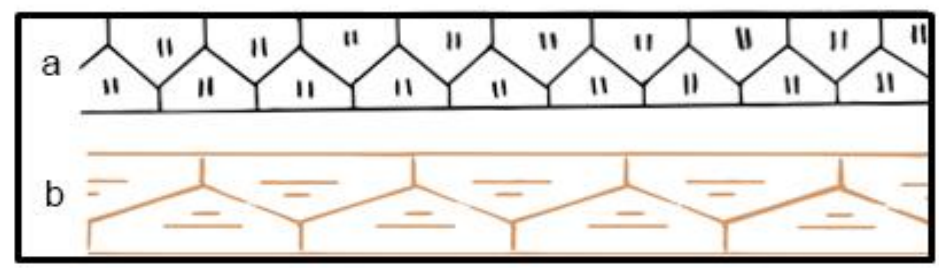

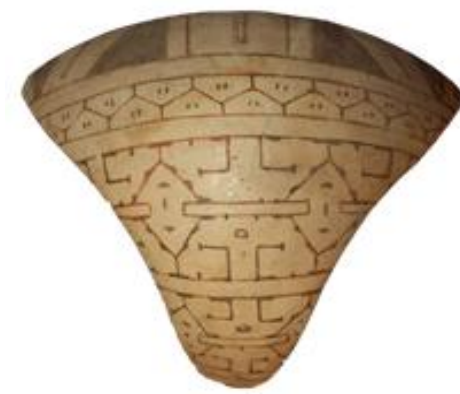

a1

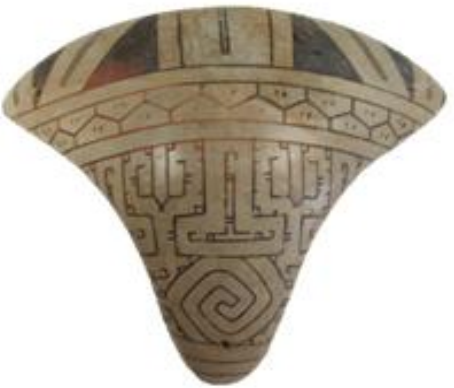

a2

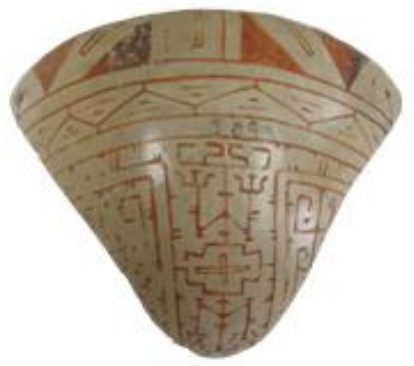

b

Figura 33- Padrões da banda 2 do tipo 3 compostos por motivos em forma de pentágonos com linhas duplas no interior e replicados pela reflexo deslizante, compondo um padrão do tipo allover. a1: MAE-USP/ ICBS; a2, b: Museu Nacional.

\section{O painel gráfico}

O campo que ocupa a maior porção da tanga é aquele que chamamos aqui de painel gráfico, localizado sempre abaixo da banda 2, e separado dela por uma faixa estreita da cor do engobo. É também o campo que possui a maior variabilidade e nele se encontra uma miríade de combinações de elementos gráficos que aludem sempre a tipos específicos de imagens. A composição das imagens vistas aqui está estreitamente relacionada a certas características estruturais, como a delimitação dos espaços e a repetição dos motivos gráficos por movimentos simétricos ou pelo desdobramento.

O layout deste campo é um aspecto determinante no arranjo dos padrões e, por isto, as tangas que apresentam uma estrutura semelhante, também apresentam temas iconográficos semelhantes ou bem parecidos. Há vários modos de estruturá-lo, mas os mais comuns são os seguintes: 
1- O painel gráfico é subdividido em painéis menores que podem ser verticais ou horizontais. Ou podemos descrever estes painéis como sendo compostos por um motivo gráfico que é espelhado (duplicado ou desdobrado)
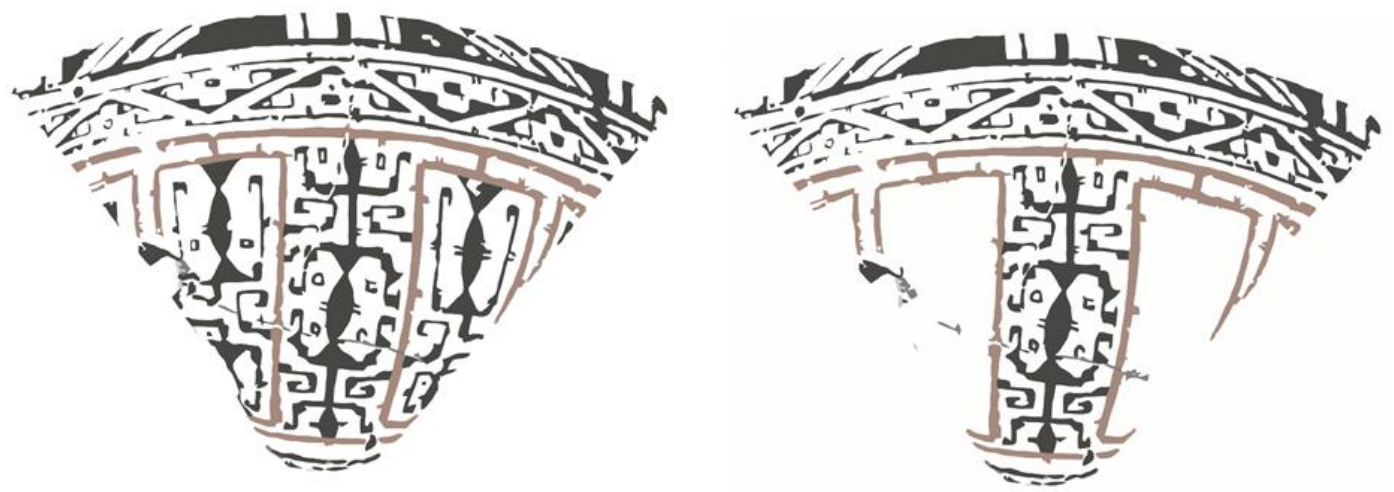

Figura 34- Painel gráfico estruturado em painéis verticais.

horizontal ou verticalmente (Figura 20).

2- Não há uma divisão prévia do painel, mas apenas o desdobramento horizontal de um motivo. Aqui, a simetria é um aspecto essencial deste tipo de padrão composto sem um layout preliminar (figura 21).
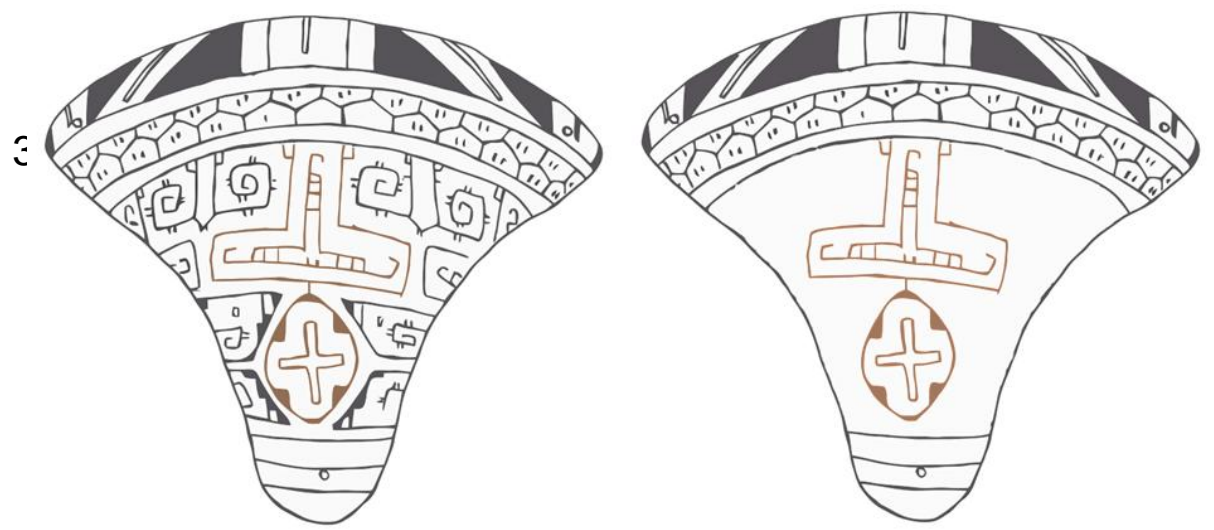

Figura 35. Campo gráfico estruturado a partir da disposição de elementos gráficos sobre um eixo virtual.

3- O painel gráfico pode ser subdividido em retângulos quadripartites, cujo número pode variar. Aqui, retângulos inteiros são repetidos a partir das laterais ou do centro do painel por meio da translação (Figura 36). 

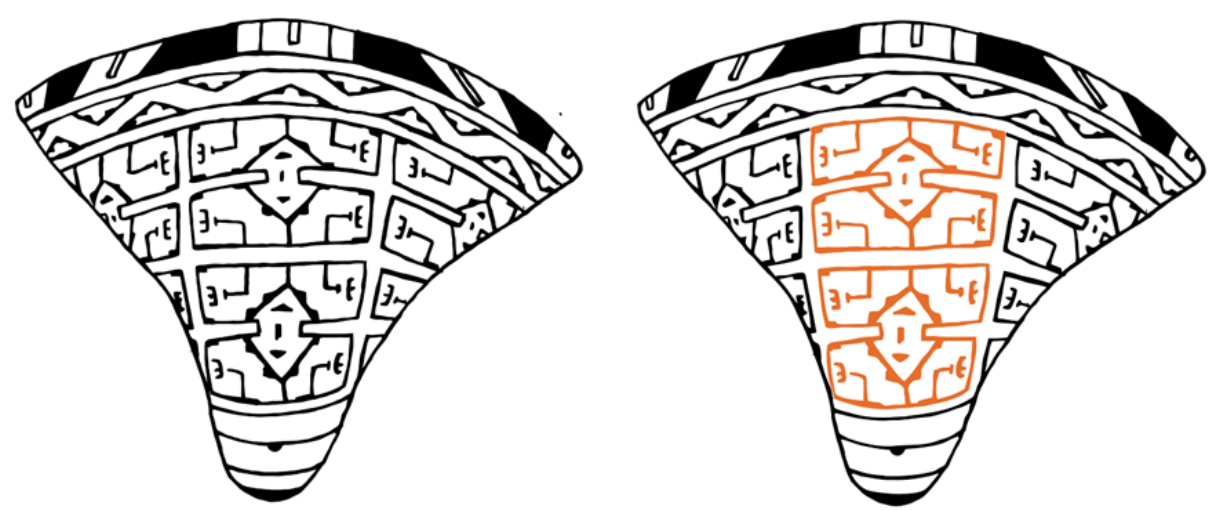

Figura 36- Estrutura do painel gráfico criada a partir da repetição de quadrantes por meio da translação.

Os tipos de simetria e movimento dos padrões formados no painel gráfico estão diretamente associados aos layouts anteriormente discutidos.

Observamos que o tipo mais comum de simetria empregado no painel gráfico é a reflexão, ou simetria bilateral. Outros tipos de simetrias ocorrem, mas são mais incomuns. Entre as 210 tangas analisadas a simetria bilateral é mais frequente no painel gráfico do que outros tipos de simetria, conforme pode ser observado na tabela abaixo.

\begin{tabular}{|c|c|c|}
\hline \multicolumn{3}{|c|}{ Simetrias observadas no painel gráfico } \\
\hline Tipo de simetria & Quantidade & Percent. \\
\hline Simetria bilateral & 189 & 90,0 \\
\hline Simetria complexa & 9 & 4,0 \\
\hline Simetria rotacional & 4 & 2,0 \\
\hline Assimetrias & 6 & 3,0 \\
\hline Indeterminada & 2 & 1,0 \\
\hline Total & 210 & 100 \\
\hline
\end{tabular}

Tabela 12. Principais tipos de simetrias observadas no painel gráfico e a sua frequência

Das 210 tangas, $90 \%$ apresentam simetria reflexiva, o que mostra que a reflexão é o movimento mais empregado na composição do painel gráfico. Nestes painéis há sempre um eixo de simetria, que é visível ou virtual, dividindo a área em duas metades iguais. Quando este eixo é virtual ele é sugerido por meio de linhas ou elementos centrais (figura 37 a e $37 \mathrm{~b}$ ) ou pode 
ser delimitado por duas áreas bem visíveis subdivididas por quadrantes ou painéis (figura 37c e 37d).

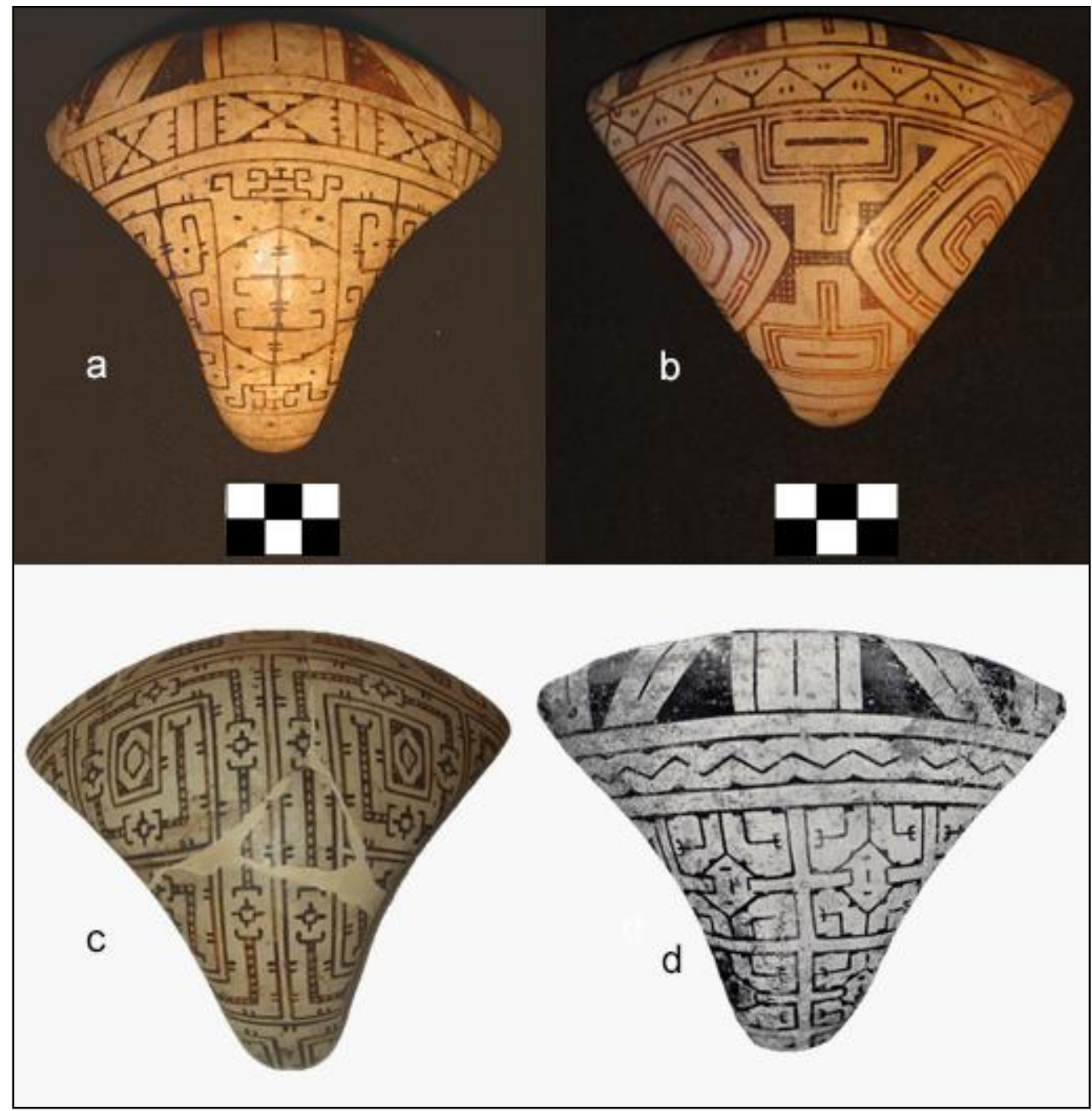

Figura 37. - Padrões gráficos compostos por meio da simetria reflexiva, ou bilateral. Notase em $A$ e $B$ que o eixo de simetria é um eixo virtual, enquanto em $C$ e $D$, os eixos são sugeridos por meio dos limites dos próprios motivos gráficos.

a, $\mathbf{b}$ - Museu Paraense Emílio Goeldi, Belém.

c- Museu de Arqueologia e Etnologia/ USP, São Paulo.

d- Museum Für Völkerkunde, Berlim. Fonte: Mordini, 1929.

Os padrões do campo gráfico, compostos por meio da repetição simétrica, como vimos, sugerem a sua continuação para além dos limites das tangas. Estes padrões se apresentam como um enquadramento específico que visa delimitar uma figura específica a partir de uma rede gráfica infinita, ao modo das "janelas ao infinito" vista na arte gráfica dos Asurini e outros povos indígenas amazônicos. Por ora não iremos nos focar neste aspecto, pois voltaremos nele ao longo deste capítulo. Bastante interessante neste 
enquadramento, contudo, é que ele cria uma imagem cuja estrutura e efeito visual priorizam um jogo vertical de movimentos.

Os padrões das duas bandas também sugerem a sua continuidade em um plano virtual, entretanto, eles não destacam uma imagem específica dentro de uma imagem maior, mas sim várias figuras que são sugeridas por meio da cadência dos movimentos, e que se movimentam em um plano horizontal infinito. Temos aqui, então, um jogo visual pautado em movimentos e efeitos visuais distintos, isto é, figuras que apreendem o olhar do espectador conduzindo-o através de um plano horizontal para áreas não visíveis da imagem, e figuras cuja verticalidade conduz o olhar para dentro de si mesmas. Isto poderia ser indício de um sistema visual pautado em escalas de visibilidade e invisibilidade, ao modo das imagens quiméricas dos contextos etnográficos (Severi e Lagrou, 2013), sugerindo que as diferentes partes da imagem se relacionam entre si através de operações estruturadas por meio da complementaridade entre aquilo que é dado a ver (no caso das imagens verticais do painel gráfico) e aquilo que é sugerido (no caso das imagens horizontais das bandas).

\subsection{As partes anatômicas do corpo}

As imagens vistas nas tangas abrangem composições elaboradas por meio da junção de figuras que aludem a diversos seres e partes anatômicas de seres. Deste modo, muitos dos padrões dos seus campos gráficos compõem imagens reconhecíveis de corpos, muitos de animais, e partes de corpos, tais quais faces e olhos. Nas tangas ilustradas na figura abaixo, por exemplo, é possível observar algumas das várias figuras que integram o repertório iconográfico marajoara. Nelas, corpos de sauros e a pequenas faces integram outras figuras. 

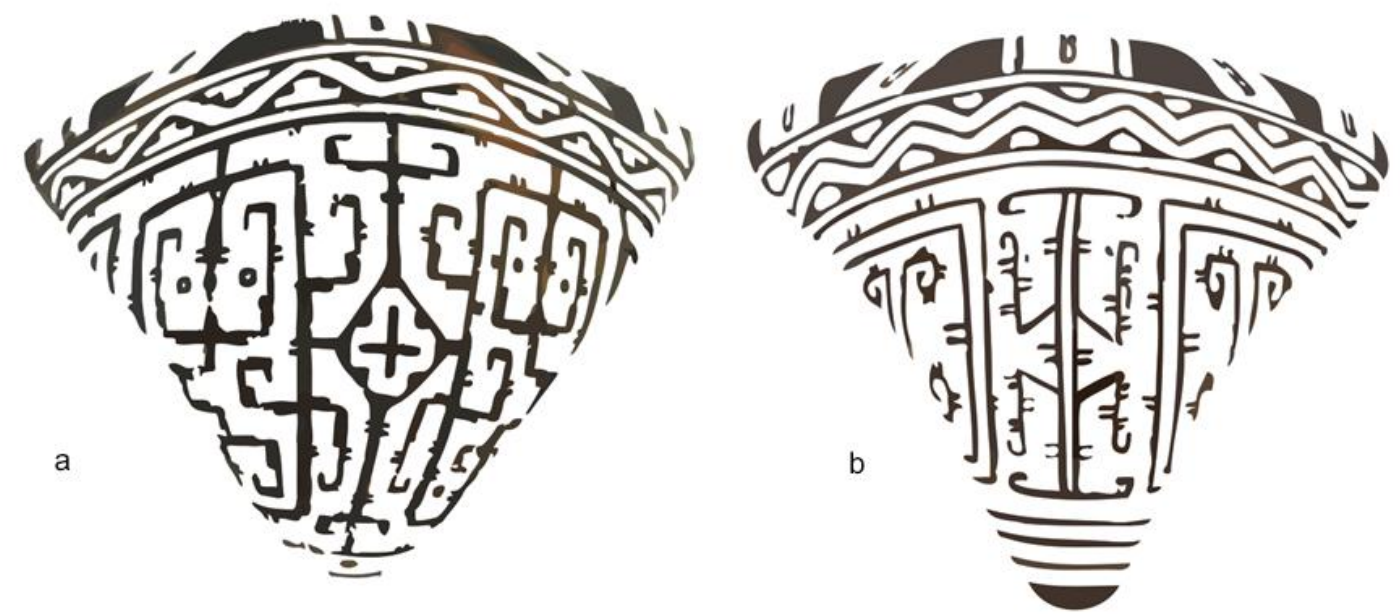

Figura 38. Tangas com padrões gráficos onde é possível observar corpos de seres e partes de corpos, como faces.

a. Coleção Oliveira, Museu do Estado de Pernambuco, Recife.

b. Musée d'ethnographie de Genève, Geneva.

No decorrer deste trabalho observamos que as imagens figuradas nas tangas são compostas por diferentes seres, em um número limitado. Estes seres, conforme já observado por Schaan (1997:53) podem estar presentes de maneira mais icônica, trazendo uma semelhança com aquilo que representam, e de maneira mais abstrata ou esquemática, quando construídos a partir da condensação ou simplificação de um signo icônico ou quando construídos a partir de mais de um referente. Em sua análise iconográfica da cerâmica marajoara Schaan (op.cit.) observou que as figuras icônicas são figuradas, principalmente, a partir da modelagem no corpo ou apêndices dos vasilhames, enquanto que as figuras abstratas são predominantes na decoração excisa, incisa e pintada.

Em nossa análise iconográfica das tangas lidamos com um sistema de figuração pautado exclusivamente na pintura como uma técnica de cobrir corpos cerâmicos. Disto resulta um emaranhando de grafismos rebuscados que à primeira vista parecem apenas linhas e figuras geometrizadas. Entretanto, percebemos que neste emaranhado de linhas e figuras geometrizadas se escondem imagens com várias figuras ocultas em seu interior. Percebemos também que estas imagens ocultas nos grafismos são compostas por um número limitado de seres, e estes sofrem diversas manipulações gráficas, o que cria figuras diferentes, mas que mantêm relações entre si. Estes seres, figurados de maneira mais bidimensional, e 
consequentemente, mais simplificados ou abstraídos, são os mesmos figurados de maneira mais figurativa de forma modelada, nas urnas funerárias e outros vasilhames.

Notamos que as imagens figuradas ali apresentam algumas características paradigmáticas que são essenciais para que possamos refletir sobre a agentividade destes objetos. Tais características estão relacionadas àquilo que Lagrou (2013) chamou de técnicas perspectivistas que possibilitariam ao espectador mudar de ponto de vista e ver outras imagens. Estes procedimentos formais que, nas tangas, possibilitam ver outras imagens são os seguintes:

1. Relação multiescalar. A imagem final é composta de partes que aludem à própria imagem. Com isto, a imagem é elaborada por meio de um procedimento de figuração que consiste de uma relação multiescalar entre as partes da imagem, como por exemplo, uma grande face pode ser composta por faces menores. Este modo de figuração não deixa de aludir aos homúnculos, isto é, uma pessoa ou ser contido dentro de outro, que na teoria de Gell (1998: 131) são também responsáveis pela "animação" dos objetos e imagens por meio da sua relação com os componentes externos. Em termos de agentividade, estes homúnculos tornam as imagens mais complexas, com maior capacidade de "viscosidade", ou seja, de prender o olhar, determinando, assim, a maneira como o espectador se relaciona com elas.

2- Relação metonímica entre parte e todo. A imagem é o produto de uma relação dinâmica entre as partes da imagem e a imagem como um todo. Aqui, no caso das tangas, uma face, isto é o todo, pode ter as suas partes, como os olhos, boca e nariz, por exemplo, compostos pelo corpo de um ser sauroforme.

É importante destacar que a comparação entre objetos que compartilham formas diferentes de decoração, mas são provenientes do mesmo contexto cultural, é crítica para o entendimento dos seus princípios estruturais. Wallis (2013), por exemplo, percebeu semelhanças iconográficas entre os vasilhames Swift Creek que possuem gravuras estampadas por meio de carimbos e os vasilhames Weeden Island, cujas figuras são modeladas, ambos do perído Woodland intermediário, do sudoeste dos Estados Unidos. A sua análise mostrou que os dois tipos apresentam os mesmos temas 
iconográficos, mas tratados de formas diferentes, no caso de Swift Creek, bidimensionalmente, e no caso de Weeden Island, tridimensionalmente.

Percebemos a recorrência de vários motivos graficos que parecem fazer alusão sempre aos mesmos seres. Estes motivos às vezes podem ser mais facilmente reconhecíveis, outras vezes, estes seres se apresentam de maneira mais esquemática, mas ainda assim trazem semelhanças morfológicas com aqueles identificados à primeira vista, o que, em um contexto cultural, subjacente a ontologias e cosmovisões específicas, a abdução da agência, nos termos de Gell (1998), poderia desempenhar um papel fundamental, já que poderiam ser reconhecidos pelas relações que mantêm entre si.

Schaan (op.cit.) observou a existência, em certas urnas funerárias, de um réptil bastante estilizado, com cabeça, corpo, rabo e membros, figurado por meio da modelagem. As características deste ser são bastante ambíguas, ora sugerindo alguma espécie de

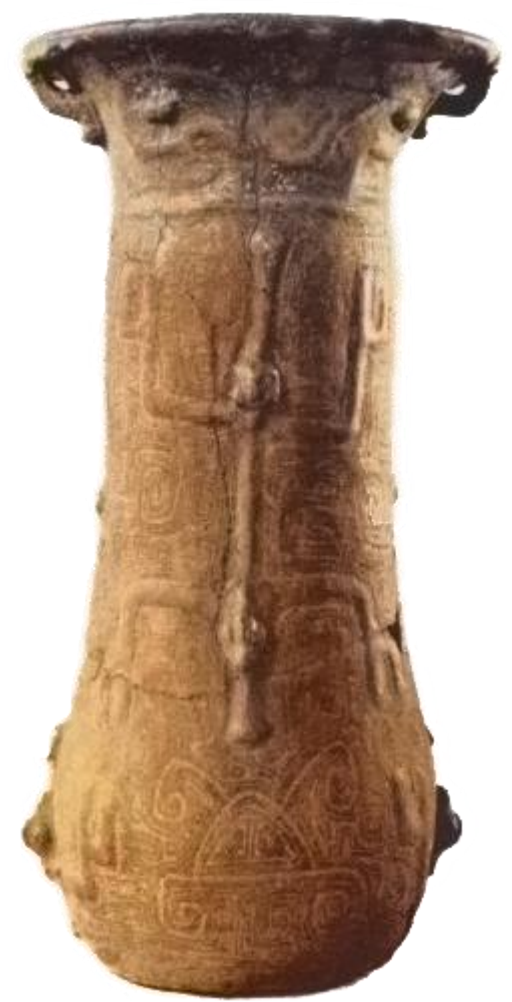

Figura 39 - Urna Funerária com decoração excisa e figura sauromorfa modelada. University Museum. Fonte: Palmatary, 1950. jacaré, ora sugerindo um lagarto. Conforme observado por Schaan (op.cit.), ele pode ser elaborado de maneira mais "figurativa", e pode também ter a sua estrutura sintetizada em uma linha vertical compondo o seu tronco e duas linhas horizontais compondo os seus membros, e pode ainda ser simplificado a tal ponto de ser reduzido a um trígito. Outra característica emblemática destas figurações diz respeito à duplicação simétrica da figura, de modo que às vezes ela pode apresentar duas cabeças, uma em cada extremidade, como se vê abaixo (Figura 40). 

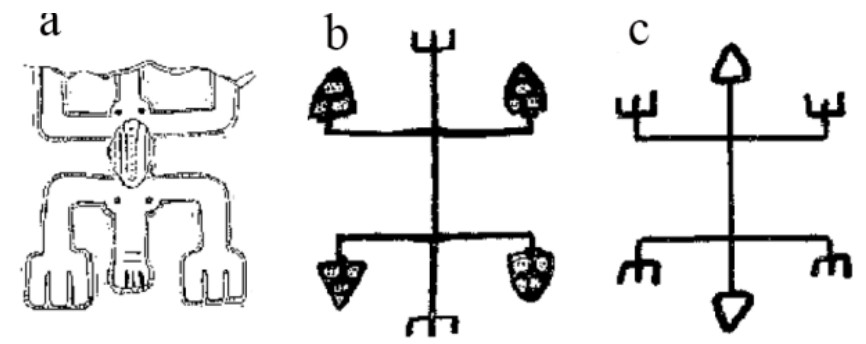

d

Figura 40- Figurações do "sauro" desde a sua figuração mais realista até a sua simplificação mais elementar. Fonte: Schaan, 1997.

Este ser sauromorfo é também figurado em outros vasilhames por meio das técnicas de incisão e excisão e, pelo que percebemos, sempre mantêm algumas características básicas ou estruturais, como por exemplo, dorso figurado de forma losangular ou amendoada, os membros podem ser figurados com patas contendo dois ou três dedos.
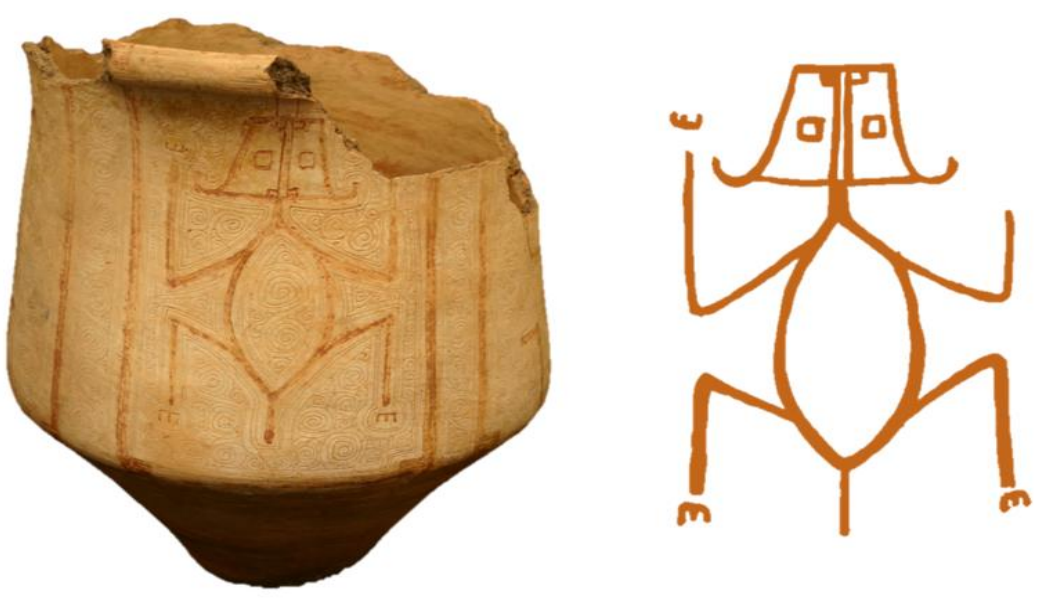

Figura 41. Ser sauroformo figurado em urna. Nota-se a forma amendoada do seu corpo, o que parece ser uma característica básica de sua figuração. Acervo do Sistema Integrado de Museus e Memoriais/ SECULT-PA, Belém. Fotografia: Armando Queiroz.

Em nossa análise iconográfica verificamos a recorrência de motivos gráficos que parecem aludir a esta figura sauroforme. Embora seja figurado mais esquematicamente nas tangas, em comparação às suas figurações nas superfícies de urnas funerárias e vasilhas, é possível notar algumas recorrências estruturais na maneira de figurá-lo, tais como:

1. Em muitos casos o seus membros podem sair da linha principal do seu corpo, postos flexionados de modo a sugerir um tronco losangular. 
2. Tronco figurado ou sugerido por forma losangular ou amendoada e, por vezes, quadrangular.

3. As patas podem ser sugeridas por tridígitos.

4- Sempre é exibido de corpo inteiro, como se fosse visto por cima ou pela frente.

5. Corpo simetricamente duplicado.

É bastante interessante notar que estes motivos que aludem à figura do sauro são antropomorfizados. Palmatary (1950: 306) percebeu que algumas figuras combinam uma cabeça antropomorfa em um corpo de jacaré. Analogamente, Carvalho (1976) percebeu que é comum a composição de figuras híbridas que mesclam atributos antropomorfos com traços de jacarés, o que poderia ser visto tanto na representação de figuras de jacarés com cabeças humanas como na representação de cabeças humanas compostas por jacarés e suas partes anatômicas.

A figura resultante da convergência ou superposição de atributos destes dois seres foi denominada por Carvalho (1976: 18) de "jacaré-humano". $\mathrm{Na}$ iconografia das tangas esta figura é bastante comum, mas é sempre muito estilizada, apresentando também o corpo simetricamente duplicado (figura 42), ao modo das representações desta figura em outros suportes, como já observado por vários autores (Carvalho, op.cit.; Schaan, 1997). Prous e Lima (2011) sugeriram, inclusive, em um caso específico, a possibilidade de se tratar de um ser antropomorfo.

Embora seja difícil apontar na iconografia da cerâmica marajoara o que é lagarto e o que é jacaré, os hábitos dos jacarés nos parecem bastante sugestivos para entender esta figura híbrida de jacaré e humano. Este predador, embora se desloque mais habilmente na água, pode também se deslocar por terra, isto é, tem a capacidade de cruzar "mundos", assim como os indivíduos humanos que possuem a capacidade de transitar para além das barreiras corporais. 


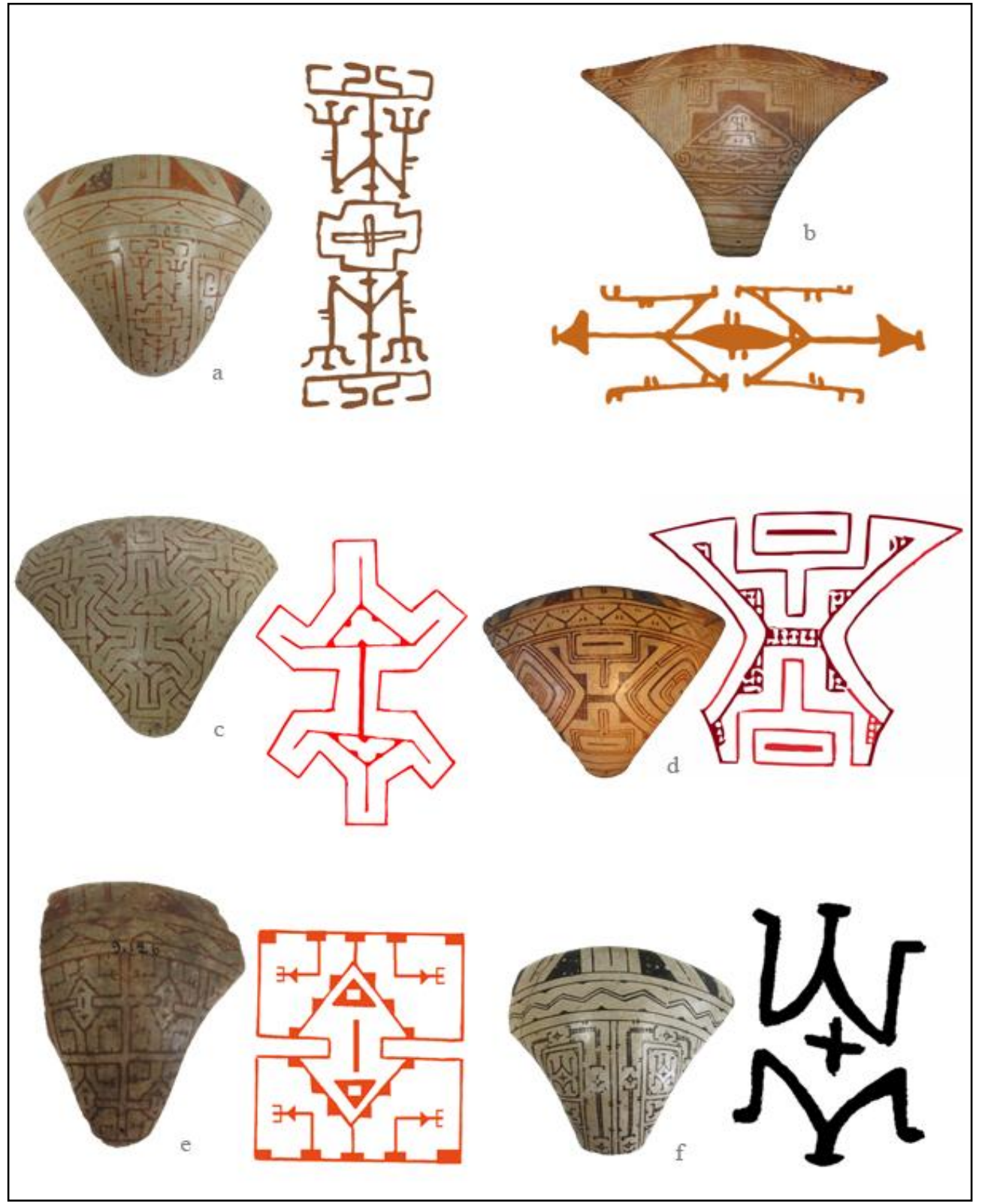

Figura 42 - Seres figurados nas tangas que poderiam aludir a sauros. Destacamse certas características, como corpo simetricamente duplicado, membros "abertos" e corpo losangular.
a, e, f: Museu Nacional, Rio de Janeiro;
b: Antiga coleção Instituto Cultural Banco Santos;
c: Museu Paraense Emílio Goeldi, Belém;
d: Coleção Oliveira, Museu do Estado do Pernambuco, Recife.

Conforme mencionado, esta figura do sauro-humano é bastante recorrente na iconografia marajoara, sendo identificada por características bem específicas. Palmatary (1950:339) identificou um motivo recorrente na cerâmica marajoara caracterizado por figuras em forma de quadriláteros, como losangos e retângulos, com um elemento cruciforme em seu interior ao qual chamou de "cruz no medalhão" (figura 43). É interessante observar que este motivo 
aparece sempre associado à figura do sauro, constituindo o seu dorso ou ventre, o que foi, inclusive, observado por Carvalho (op.cit.).

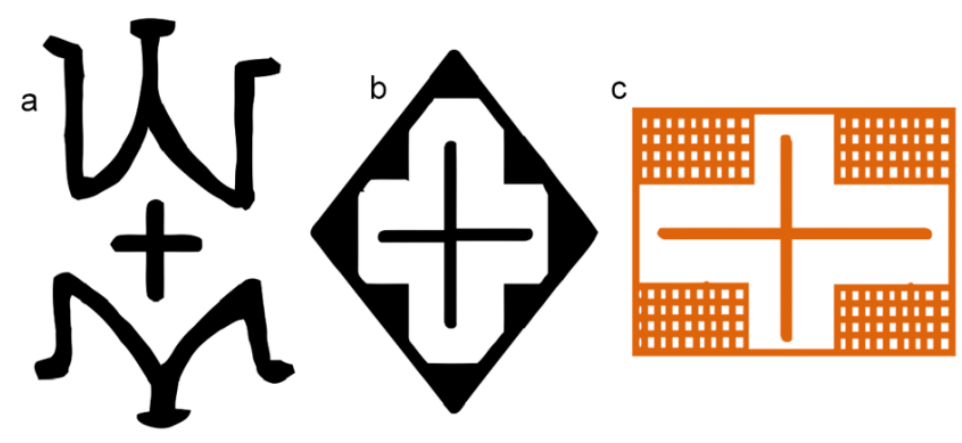

Figura 43. Motivos "cruz no medalhão" que constitui o dorso do sauro em muitos casos.

a. Motivo aludindo ao sauro-humano com o dorso constituído pelo motivo.

b, c. Motivos cruz no medalhão, como vistos nas tangas.

Curiosamente, é muito comum que este motivo seja elaborado por retículas ou seja acompanhado por linhas reticuladas com tridigítos nas extremidades, como se vê, por exemplo, em algumas tangas do grupo 4, descritas mais a frente. Observamos também, em algumas tangas, como aquelas do grupo 7, que estas linhas reticuladas podem estruturar figuras em forma losangular que aludem ao corpo do sauro. Schaan (1997: 154-155) observou simplificações de figuras serpentelíneas em forma de linhas reticuladas que aludiriam às escamas vistas no ventre das serpentes. No entanto, é possível que estas retículas também aludam ao padrão constituído por retículas que é visto no ventre de várias espécies de jacarés.

Além da figura descrita, há outra que aparece com certa frequência nas tangas e que desempenha um papel fundamental na composição de certas imagens. Embora esta figura tenha sido identificada anteriormente como uma cobra ou serpente (Prous e Lima, 2011), algumas das suas características aludem a outro ser. Esta figura, assim como o sauro, ora é mostrado de maneira mais figurativa, ora de maneira mais "simplificada", o que parece estar relacionado à técnica usada para figurá-lo em certas superfícies, isto é, modelagem, incisão, excisão ou pintura, conforme é possível observar nas figuras 44 e 45 . 


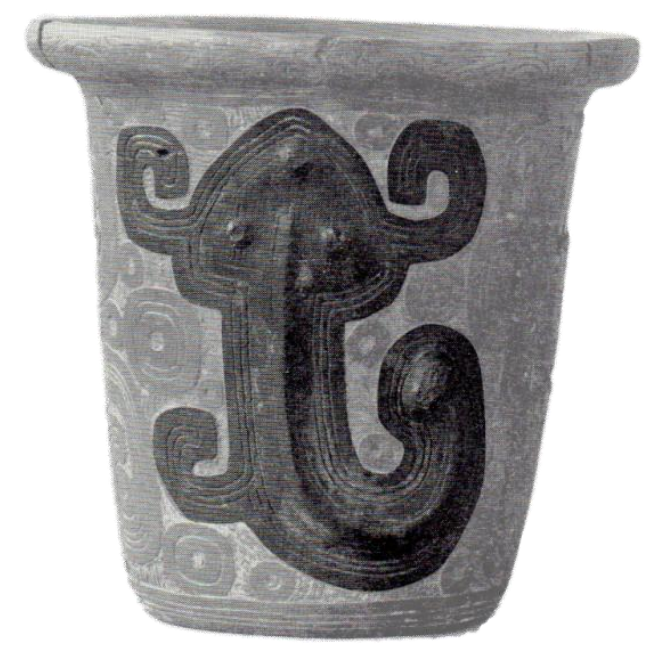

Figura 44- Detalhe destacando o motivo que alude à figura do peixe-serpentilíneo em uma urna funerária proveniente do conjunto Fortaleza. University Museum. Fonte: Palmatary, 1950.

As suas características aludem tanto aos seres serpentilíneos quanto a alguns seres com características pisciformes. A sua cabeça é de formato triangular e, em muitos casos, pode apresentar escalonados com alguns traços que formam características faciais. Desta cabeça saem alguns elementos como volutas ou ganchos, assim como também do seu corpo alongado, que poderiam representar bigodes.

É importante destacar que um conjunto de motivos triangulares com escalonados que Palmatary (1950: 343) designa como "pirâmide escalonada", de acordo com o que

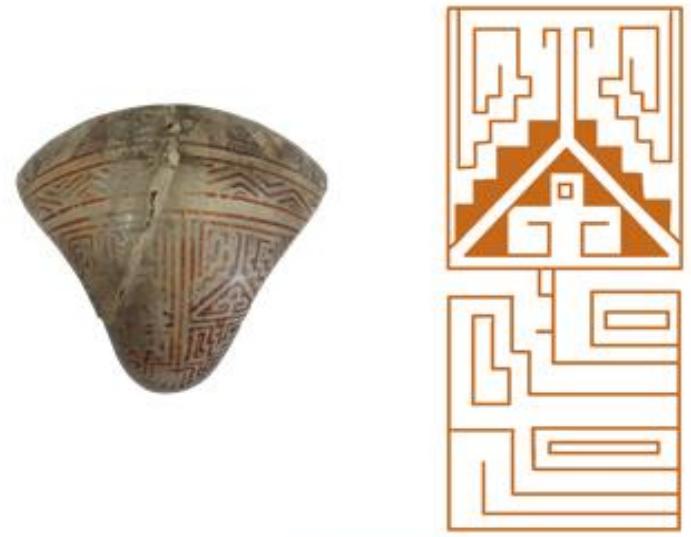
temos verificado na iconografia das tangas, poderia compor figurar a cabeça deste ser. Na maioria das vezes, este ser é figurado priorizando-se a elaboração da sua cabeça e, com isto, o seu corpo, quando presente, se reduz a linhas simples, duplas ou reticuladas. Estes motivos triangulares com escalonados podem ser elaborados de maneira mais icônica, quando a cabeça deste ser apresenta elaborações que sugerem a sua 
face (figuras 46a, 46b, 46c, 46d), ou mais simplificados, quando são reduzidos a motivos triangulares cujos escalonados foram elaborados na sua parte interna, criando uma figura negativa em T, ou seja, uma "pirâmide escalonada invertida", como é possível observar nas figuras 46 e e $46 f$.
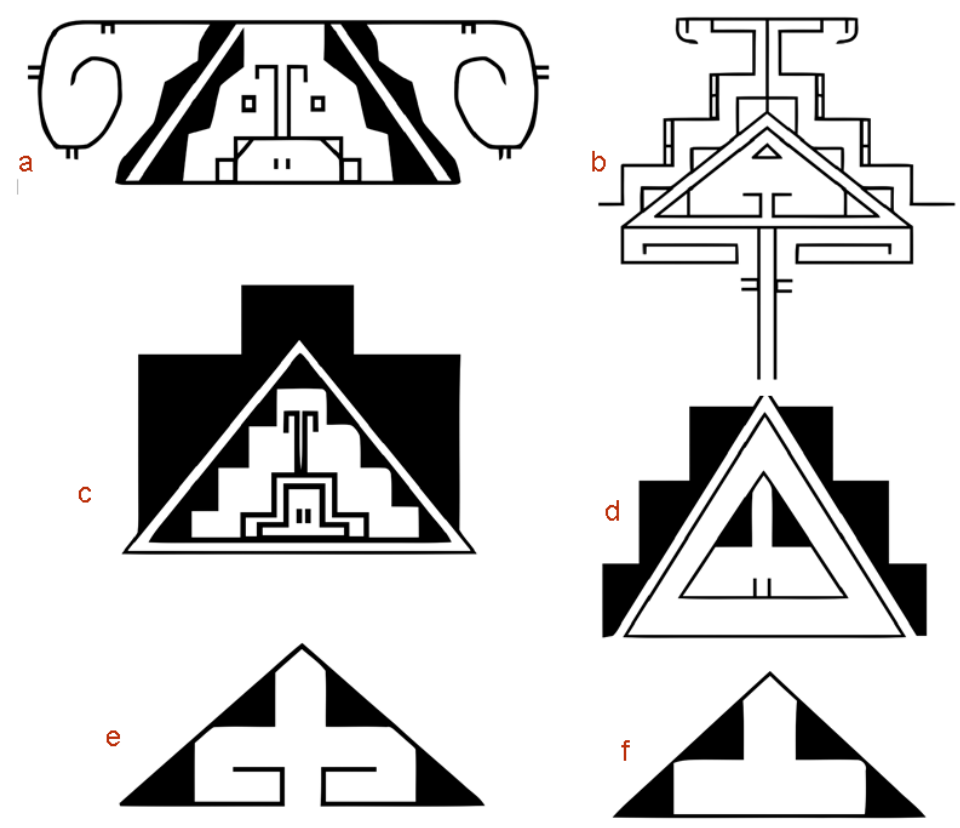

Figura 46. Motivos "pirâmide escalonada" que aludiriam à cabeça do ser serpentelíneo. a,b.c,d. Motivos elaborados de maneira mais icônica.

e,f. Motivos simplificados com os degraus invertidos criando uma figura em negativo em forma de $\mathrm{T}$ em seu interior.

As características vistas na cabeça deste ser lembram traços vistos nos peixes da ordem Siluriformes. Estes peixes são conhecidos como bagres e também peixe-gatos devido à presença dos seus barbilhos, próximo a suas bocas, e que se assemelham às vibrissas existentes nos felinos. Mais especificamente, dentro da família de peixes Pimelodidae, que abrange bagres de água doce e que são encontrados por toda a América do Sul e América Central, há um gênero conhecido como Sorubimichthys de onde se sobressai a espécie Sorubimichthys planiceps, peixes conhecidos popularmente como Surubim-chicote, Surubim-lenha ou Peixe-lenha e que possuem uma dispersão bem ampla, o que inclui a Bacia do Orinoco, Bacia do Amazonas e Bacia do Tocantins-Araguaia. $^{31}$

\footnotetext{
${ }^{31}$ Consultado em ambientes.ambientes.brasil.com.br e em www.fishbase.org
} 
Algumas das características mais marcantes das espécies de surubim incluem longos barbilhos junto à boca, cabeça larga e corpo muito fino. De fato, o seu corpo é muito alongado e roliço e com um comprimento que pode atingir até um metro e meio. Estas características são bem sugestivas, principalmente se comparadas às características da figura que estamos tratando na iconografia marajoara, cujos traços incluem uma grande cabeça triangular da qual saem volutas ou ganchos que poderiam remeter aos barbilhos daquele bagre. Além disto, o corpo desta figura é bastante alongado e mais fino do que a sua cabeça, da mesma forma que o do bagre. Entretanto, é muito difícil fazer qualquer referência com esta ou qualquer outra espécie de peixe, visto que, conforme Schaan (1997:148) mostrou, nem sempre as figurações dos animais obedecem aos princípios anatômicos, de modo que somente algumas características são empregadas, mas sem fidelidade ao protótipo.

Esta associação se torna ainda mais problemática, principalmente, devido ao caráter dinâmico da iconografia marajoara, onde um ser pode ser vários seres ao mesmo tempo. A serpente, um ser bastante frequente na iconografia desta cerâmica, sobretudo, nas urnas funerárias do tipo Pacoval Inciso (Figura 47), possui também um corpo alongado, por esta razão é complicado definir se o ser em questão é um peixe ou uma cobra, pois talvez seja ambos. Como vimos, o mesmo ocorre com a figura do sauro, onde um jogo pautado em semelhanças e qualidades agentivas expressa as relações entre os referentes, de modo que em certos casos a figura pode ser ao mesmo tempo, um ser zoomorfo, antropomorfo e antropozoomorfo. 

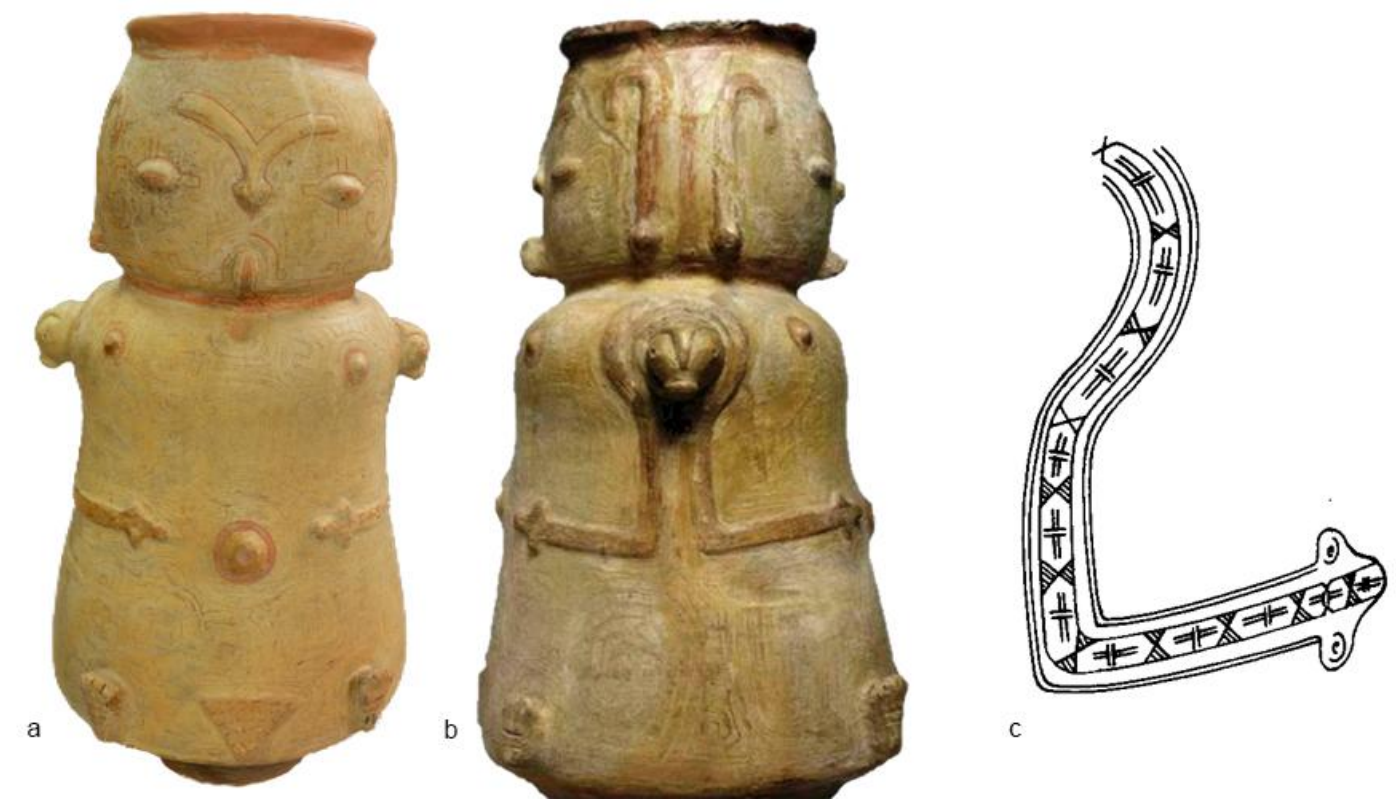

Figura 47- Motivo de serpente em urna do estilo pacoval inciso. Museu Etnológico de Berlim. Fonte:
a. smb.museum. Fotografado por Christin Griesheim.
b. Barreto, 2009.
c. Schaan, 2001. Desenhado por Garth Denning

Diante do exposto, de modo a evitar pressupostos falaciosos, ao caracterizar este ser como peixe ou como serpente, julgamos conveniente referir a ele como peixe-serpentilíneo. Oliveira (2016) percebeu na iconografia da cerâmica Guarita da Tradição Policroma da Amazônia a ocorrência de uma figura que designou de peixe-cobra. Este ser, ao mesmo tempo em que apresenta características serpentilíneas, assim como a figura da iconografia da cerâmica marajoara de que tratamos aqui, apresenta alguns aspectos que poderiam aludir a certos peixes, como os bagres. Esta autora percebeu que algumas das características deste ser, como cabeça triangular e escalonada e com linhas junto à cabeça que aludiriam aos barbalhos de certos peixes, tornam esta figura muito semelhante àquelas que existem nas iconografias andinas, o que poderia indicar o compartilhamento de uma estrutura ontológica pan-americana, expressa nas artes e na linguagem simbólica de cada sociedade (Oliveira, 2016: 262).

Estes dois seres acima descritos estão presentes na maioria das imagens elaboradas nas tangas, seja de forma icônica, seja de forma mais simplificada, compondo as suas partes. No geral, eles são decompostos, recompostos, e, muitas vezes, misturados para a composição de novos seres e 
figuras. Diante disto, é necessário, antes de seguirmos adiante, um enfoque especial sobre as atuais teorias a respeito da figuração e formas de percepção no mundo ameríndio.

\subsubsection{Imagens compósitas no mundo ameríndio}

$\mathrm{Na}$ arte ameríndia, a produção de corpos e imagens está relacionada a cosmovisões estruturadas por ontologias específicas. Esta produção é muitas vezes pautada por uma lógica que entende o corpo como um constructo obtido a partir de corpos ou partes anatômicas de outros seres. Especificamente na Amazônia ameríndia, Santos-Granero (2012: 41-42), com base em sua experiência entre os Yanesha, mas também considerando a experiência de seus colaboradores entre vários grupos, como os Tukano, os Mamaindê, os Urarina, os Waujá, entre outros, identificou o que ele chama de "ontologias construtivistas". Estas ontologias concebem todos os seres vivos como entidades compostas, feitas de corpos e partes corporais de uma miríade de formas de vida. Aqui, todos estes seres com as suas anatomias compostas resultaram de processos envolvendo a decomposição e a reconstituição dos corpos de demiurgos e humanos

Entretanto, os arranjos anatômicos decorrentes disto são muito instáveis, e com isto, os corpos são propensos a constantes transformações e metamorfoses.

$\mathrm{Na}$ Amazônia, este modo de figuração pautado no caráter compósito e na transformação potencial dos corpos é amplamente disseminado. Entre os Wajana, por exemplo, devido

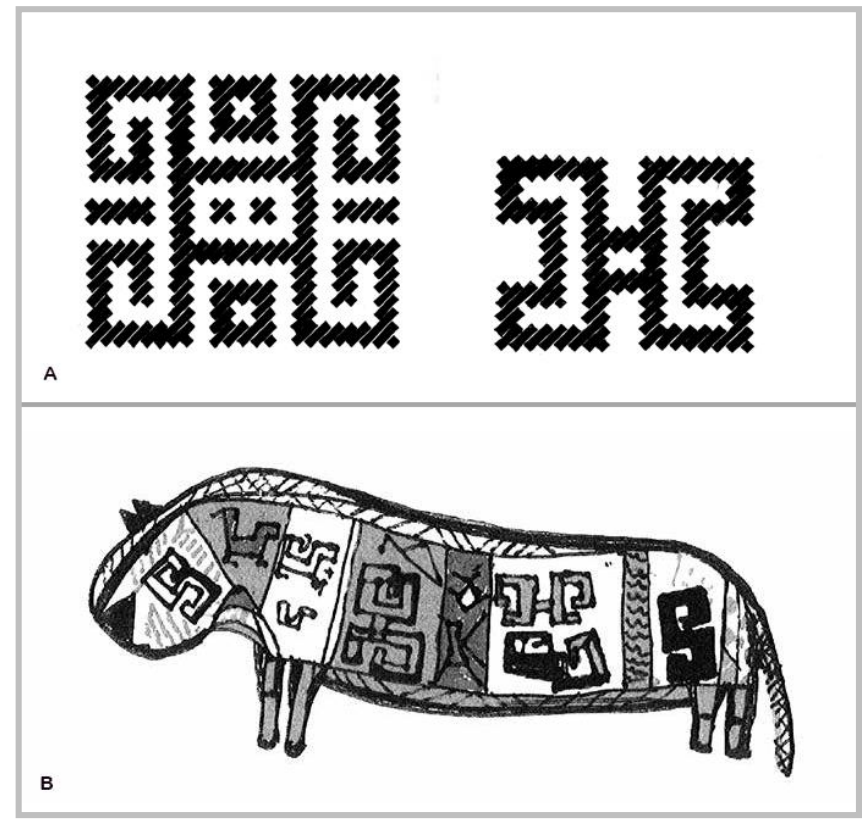

Figura 48: Temas gráficos wajana. A: Tema "caranguejo/olho de anta". B: tema gráfico onçacaramujo visto na pintura. Disponível em Severi (2013).

ao perpétuo processo de transformação das coisas, cada ser pode assumir a 
pele de outro ou de vários outros seres ao mesmo tempo. Em sua arte gráfica certos grafismos podem ser decompostos em diversas partes que possuem significados independentes, como é o caso do tema gráfico do "caranguejo", que contém o tema do "olho da anta". Ainda na arte wajana, esta anatomia compósita pode ser empregada para a figuração de um ser com temas gráficos que aludem a suas possíveis transformações, fazendo isto por meio do desenho de um único animal que traz em sua pele temas gráficos que representam outro (Severi, 2013: 56).

Estas anatomias compósitas são vistas também em imagens provenientes de contextos arqueológicos, sempre aludindo a transformações corpóreas, conforme pode ser visto em certos vasos da Tradição Policroma da Amazônia, cujos temas iconográficos remetem a seres antropomorfos com braços serpentilíneos formando outros seres como felinos, aves e outros corpos em transformação (Oliveira, 2016). Uma anatomia semelhante é vista também em certas urnas funerárias do estilo Pacoval Inciso, da ilha do Marajó, onde os braços são compostos por cobras, os ombros por apliques modelados como cabeças de pássaro e olhos em forma de escorpião (Barreto, 2014).

A corporalidade e a potência transformativa dos corpos, bem como as suas relações com as cosmovisões específicas têm sido o foco de abordagens teóricas centradas no estudo das imagens do mundo ameríndio. Estas estão preocupadas com as técnicas de percepção e materialização das imagens em ontologias perspectivistas, marcadas pela potência transformativa dos corpos e pela comunicação das interioridades escondidas neles (Lagrou, 2008; Lagrou e Severi, 2013).

O foco destas abordagens tem recaído sobre as imagens compósitas e na relação entre as suas diversas partes, bem como na cadeia de operações cognitivas relacionadas à sua percepção. Severi $(2007,2013)$ denominou de "quiméricas" as imagens cuja intensificação de sua eficácia se dá pelo processo de mobilização das suas partes invisíveis através da inferência visual. Estas associam em uma única forma índices visuais provenientes de uma miríade de seres, cujos traços visuais oferecem poucas pistas ao olhar e, portanto, para a sua interpretação o observador necessita projetá-la mentalmente, completando os seus traços invisíveis por meios puramente visuais (um olho mental) ou por um conjunto de inferências (Severi, 2013:45). 
O que caracteriza morfologicamente estas imagens é um princípio de organização do espaço que, ao provocar diferentes tipos de projeções, cria uma ilusão específica entre uma forma mostrada e outra apenas sugerida. Com isto, estas imagens são um tipo específico proveniente da articulação entre a representação icônica e a indicação indicial de uma existência imaterial, ou seja, é uma imagem gerada pelo pensamento por meios indiciais. Esteticamente o que caracteriza o espaço quimérico, é

(...) um jogo constante de pressuposição recíproca entre percepção e projeção, já que, no âmago desse tipo de espaço, a projeção e a percepção apenas se exercem quando estabelecem uma complementaridade provisória - a forma e o fundo, o fragmento e a totalidade, o focalizado e o periférico - , intercambiando incessantemente os seus papéis (Severi, 2013: 47).

Apesar destas características definidoras, a quimera não visa apenas representar seres, mas também as relações entre eles por meio de uma lógica das relações icônicas que se desdobra tanto nas imagens como nos atos de olhar que elas implicam (Severi, 2013: 48). Este tipo de iconografia, onde a representação dos seres está intrinsecamente relacionada à representação das suas relações não é algo incomum na Amazônia (Severi, 2013:51). único ser.

Retomando o exemplo dos Wajana, a imagem quimérica ocorre em uma lógica plural onde no lugar de personagens surgem classes de seres. Ao mesmo tempo em que uma representação iconográfica pode se referir a vários seres, séries de desenhos podem se referir a um

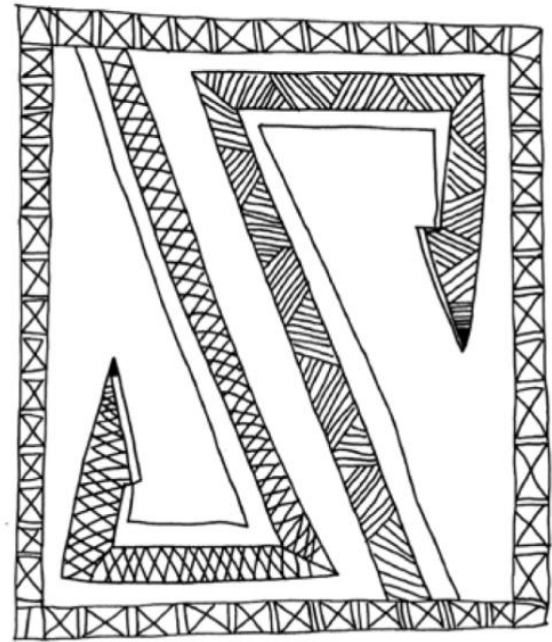

No primeiro caso, onde alguns Figura 49 motivo gráfico da cegonha maguari na cestaria wajana. Severi, motivos gráficos, apesar de guardarem a 2013. sua significação especifica, podem ser associados para designar grupos ou categorias de seres (Severi, op.cit). O motivo "bico de maguari", por exemplo, refere-se à cegonha maguari, uma ave 
considerada o protótipo de todos os seres que picam. Na ontologia wajana o ato de ferir, picar ou perfurar é considerado uma forma paradigmática de predação, onde o ato de flechar ou atingir de modo a atravessar a pele é característico das flechas e de certos animais como cobras, vespas, escorpiões e de certas aves, como a cegonha maguari. No motivo gráfico que designa esta ave, ela é indicada em posição de vigilância, mas o motivo também representa a flecha, assim como qualquer animal predador que ao modo dela atinge a sua presa, de forma que o motivo poderá designar indeterminadamente tudo aquilo que pica.

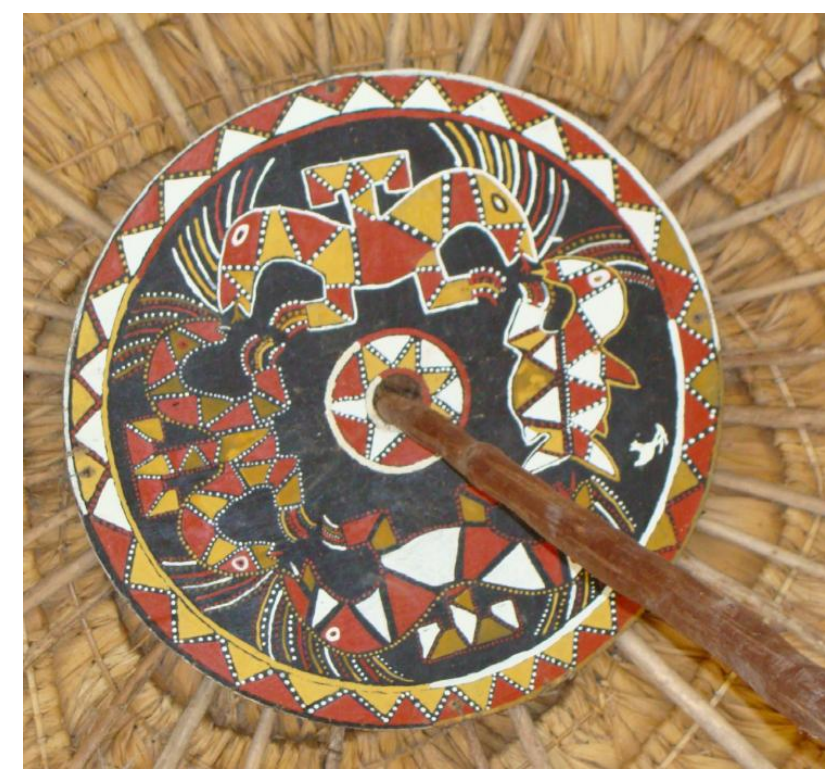

Figura 50 - Roda de teto (maluana) figurando a "raia enquanto anaconda".

A lógica que pauta o caso inverso, ou seja, quando séries de grafismos designam um único ser, é a de predador ancestral, um ser que se manifesta por meio de uma série de metamorfoses e que por isto é figurado como um ser coletivo. Isto pode ser visto, por exemplo, nas pinturas das rodas de teto da casa cerimonial, as maluana. Há uma série de temas gráficos que remetem a diversos seres híbridos, como anacondasjacarés e peixes com características de mamíferos e aves, mas cuja série figura a "raia enquanto anaconda" ${ }^{32}$.

Uma abordagem mais específica de "quimera" pautada nas especificidades do mundo ameríndio foi conceitualizada por Lagrou (2013) a partir da conciliação da proposta de Severi (op.cit.) com o perspectivismo ameríndio de Viveiro de Castro (2002). Aqui, a autora propõe que as imagens e grafismos ameríndios sejam considerados como instrumentos perceptivos que

\footnotetext{
${ }^{32}$ Esta categoria está pautada no entendimento da anaconda enquanto um modelo de predador. Para os Wajana os atos predatórios desta serpente possuem um caráter tão paradigmático que, além de remeterem à dimensão sobrenatural, podem ser aplicados a outras espécies de animais, de modo que se possa atribuir a outros seres, instintos de predação associados à anaconda, assim nestas ocasiões, a anaconda vestirá a pele destes animais (Velthem, 2003 apud Severi, 2013:54).
} 
envolvem operações mentais específicas apoiadas por uma ontologia marcada pela transformabilidade das formas e do corpo (Lagrou, 2013:68).

Esta proposta é fundamentada no postulado que considera o caráter perspectivista e "animista" das sociedades ameríndias, marcadas por uma transformabilidade das formas e pelo contraste entre uma interioridade e uma exterioridade não necessariamente coincidentes, onde um ser humano pode ocultar um corpo não-humano e um não-humano pode ocultar um corpo humano (Lagrou, 2013: 68).

A abordagem se foca, sobretudo, no dinamismo latente dos grafismos que, apesar de serem aparentemente abstratos, podem abrir e revelar à percepção uma figura (Lagrou, 2013: 69). Esta é uma característica paradigmática dos grafismos das ontologias transformacionais amazônicas, onde a relação entre tais grafismos e as figuras trazidas à percepção é marcada pela transformabilidade, e por esta razão os grafismos são vistos como caminhos para a visualização de imagens virtuais. Entre os Kaxinawa, por exemplo, o desenho é percebido como um caminho, uma porta de entrada para se referir a outras imagens em movimento, imagens estas que podem apenas ser vislumbradas para quem está preparado e em circunstâncias específicas (Lagrou, op.cit.).

Entre vários povos amazônicos existem muitos procedimentos formais característicos dos grafismos que, segundo Lagrou (2013:68), podem ser interpretados como "técnicas perspectivistas" que possibilitam ao espectador mudar de ponto de vista por meio de um enquadramento específico. Estas técnicas estão voltadas, particularmente, para a configuração do espaço perceptivo, obtida por meio do jogo entre linhas que se superpõem a um espaço preexistente, o que permite transitar alternadamente de uma percepção a outra, como por se nota, por exemplo, no jogo de contraste entre figura e contrafigura (Lagrou, 2013: 81).

$\mathrm{Na}$ arte gráfica de vários povos amazônicos, o jogo entre simetria e assimetria está relacionado à simultaneidade de mundos visíveis e invisíveis, que leva o olhar a não se deter em uma figura previamente delineada por um fundo, mas sim perceber uma figura simultaneamente com a contrafigura, 0 que, assim como as armadilhas de Gell (1998), produz um efeito sinético que 
anima o suporte e captura o olhar do seu observador, projetando-o para dentro do espaço gráfico delineado (Lagrou, 2013: 69).

Neste jogo entre o que é visto e o que é apenas sugerido, a introdução de pequenos detalhes assimétricos rompe com a simetria do conjunto e funciona como "uma tecnologia de transformação interna à estrutura da imagem", criando imagens diferentes (Lagrou, 2013: 87). Outro aspecto formal crítico diz respeito à interrupção do desenho assim que ele se torna reconhecível, sugerindo a sua continuidade para além do suporte, o que ocorre na arte gráfica de vários grupos, como por exemplo, nos tecidos Kaxinawa, na tecelagem Yudjá, na cestaria xinguana e nos desenhos Karajá e Asurini. Müller (1992), especificamente no caso dos grafismos Asurini, chama esta operação onde o grafismo é recortado para destacar uma parte do desenho infinito de "janela ao infinito".

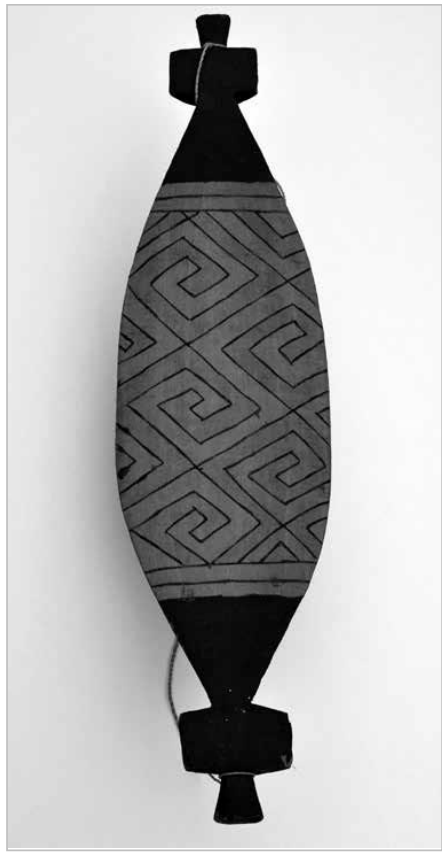

Figura 51. Banco Karajá coberto com grafismos recortados que sugerem a sua continuidade ao infinito. Fonte: Lagrou, 2013: 91

Estas quimeras abstratas, caracterizadas, como já sublinhamos, pelo grafismo enquanto uma passagem para figuração virtual, ocorre em vários sistemas gráficos ameríndios, mas particularmente entre os Asurini possuem um caráter paradigmático. Ali, toda a abstração aponta para a figuração, já que a figuração daquilo que está oculto é parte integrante da Tayngava, presente na maioria das pinturas corporais. Aqui, o grafismo se torna uma figuração virtual que possibilita completar mentalmente a imagem do Tayngava em uma imagem virtual dos espíritos a'anga a partir de poucos índices dados. Há um motivo semelhante ao Tayngava entre os

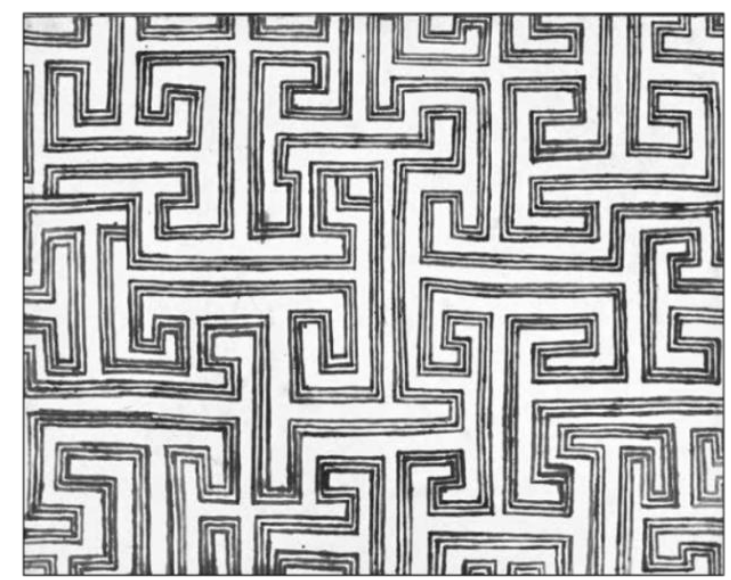

Figura 52- motivo tayngava asurini. Coleção Darcy Ribeiro, Museu do Índio, Rio de Janeiro. Fonte: Lagrou, 2013:95. 
Wauja e os Kalapalo, do Alto Xingu, que apesar de apresentar nomes diferentes entre os dois grupos, possui um caráter antropomorfizante que pode ser visto tanto no esquema do motivo que alude aos elementos mínimos da figuração humana, quanto no caráter metonímico da sua relação com o ser que o recebe, que possui capacidade de ação humana (Lagrou, 2013:95-96).

Na Arqueologia Amazônica a questão da transformabilidade dos corpos tem sido destacada por alguns trabalhos (Barreto, 2009, 2014; Oliveira, 2016). Algumas ferramentas analíticas utilizadas na Arqueologia andina, como aquela desenvolvida a partir do conceito de kenning, e voltada para o estudo das imagens elaboradas por meio da sobreposição de figuras que aludem a diversos seres ou às partes anatômicas deles, têm sido útil para a compreensão das imagens de contextos arqueológicos da Amazônia, servindo como ponto de partida para a reflexão das especificidades imagéticas vistas naquele contexto (Barreto, 2014; Oliveira, op.cit.). O uso desta ferramenta em contextos amazônicos, quando consideradas as particularidades ontológicas e cosmológicas que pautam a produção das imagens, pode ser bastante útil para entender as relações e as dinâmicas envoltas em tais imagens.

O conceito de kenning foi proposto inicialmente por Rowe (1962) para a arte de Chavín de Huántar, e posteriormente, estendido a outros contextos. Este autor sugeriu que a iconografia de Chavín deveria ser entendida em termos da construção de vários níveis e formas de metáforas visuais, começando em símiles (comparações) e metáforas simples e culminando na representação de metáforas, sendo as últimas consideradas kennings (Rowe, op.cit.; Urton, 2008).

Para Rowe (op.cit.) kenning poderia ser concebido como uma série de comparações visuais, frequentemente sugeridas por substituição de um elemento por outro. $O$ seu conceito parte de um tipo de figura de linguagem literária comum, ou tropo, muito usada em antigas sagas nórdicas. Na língua norueguesa antiga o kenning era o principal critério de julgamento da poesia, por isto os poetas criaram jogos de linguagem cada vez mais complexos e ousados e também aumentaram a frequência de seu uso. Havia duas maneiras de elaborá-lo, o kenning de kennings e a introdução de kennings dependentes de uma referência a uma história já conhecida pelos ouvintes. 
O exemplo tomado por Rowe diz respeito às figuras de linguagens usadas para se referir aos cabelos de uma mulher, que no caso em questão são, por comparação direta ou similitude referidas como "seus cabelos são como cobras"; por comparação implícita ou metáfora, por meio do uso de "seu cabelo de serpente" e, por comparação por substituição, que corresponde ao kenning, empregando apenas a figura de linguagem "seu ninho de cobras", sem usar a palavra "cabelo". Com isto em vista, o leitor só compreenderia a expressão por abdução, ou seja, caso compartilhasse do conhecimento de que o cabelo pode ser comparado a cobras, ou inferindo o seu significado a partir

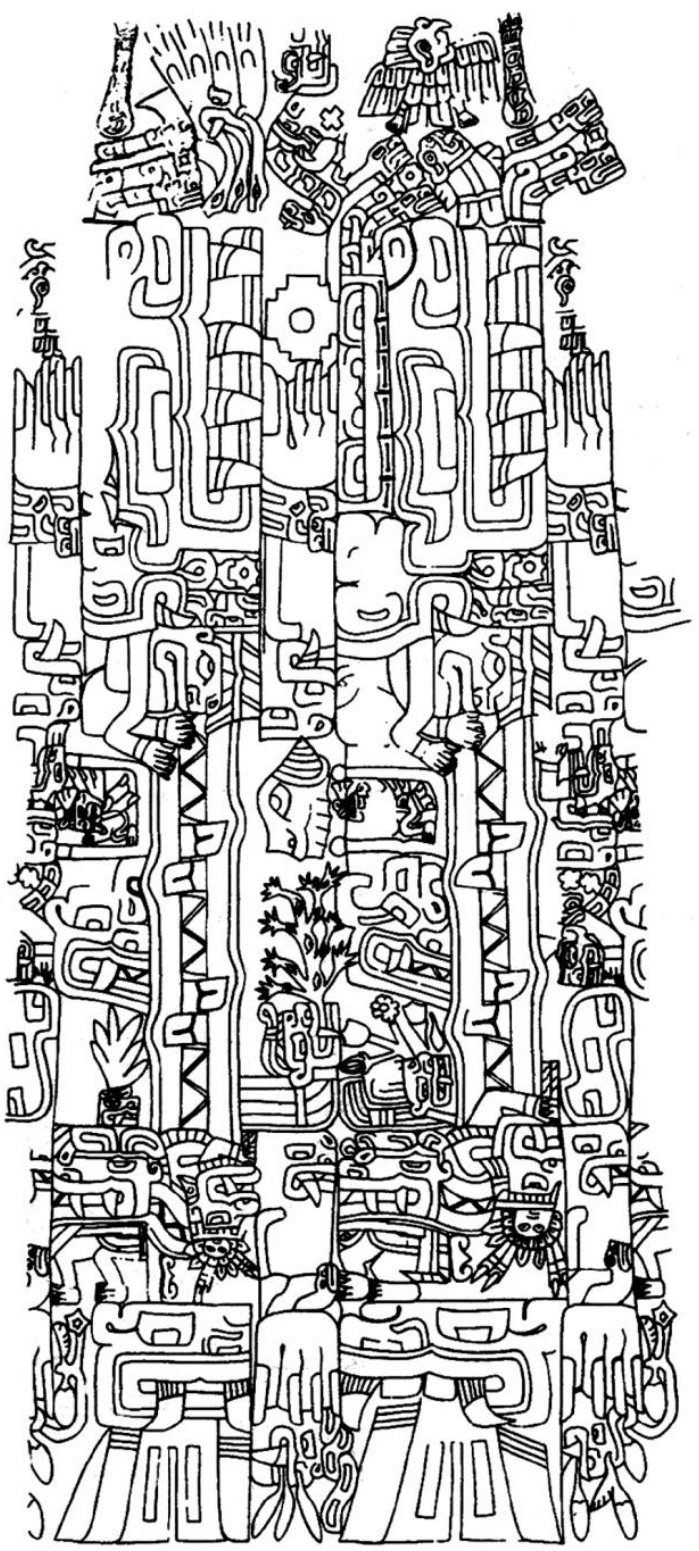

Figura 53 - Rollout dos relevos no obelisco de Tello. Disponível em Urton, 2008. do contexto em questão.

Quanto à arte de Chavín, Rowe sugere que o mesmo tipo de desenvolvimento visto na complexidade figurativa da poesia nórdica antiga também teria ocorrido ali, com kennings cada vez mais numerosos e rebuscados. Entre os vários exemplos citados pelo autor, um dos mais comuns poderia ser visto nas figurações em que a boca de qualquer criatura pode ser composta como a boca de um felino, talvez de um jaguar rosnando, com os dentes à mostra e os longos e pontiagudos caninos cobrindo os lábios. Esta boca felínica é vista não só nas figurações de felinos, mas também na boca de figuras humanas, de cobras e até mesmo de pássaros.

Especificamente para este caso, o autor pontua que o seu uso figurativo não está associado a uma comparação direta, mas por outro lado tem uma associação muito íntima com o uso de kennings. Sugere assim, 
que a boca felínica talvez tenha sido usada para distinguir os seres divinos e mitológicos das criaturas ordinárias do mundo da natureza, implicando em uma comparação entre o poder do jaguar e o poder sobrenatural.

Dito isto, é importante frisar que o uso do kenning, como proposto por Rowe, ou seja, como um recurso de linguagem cujo fim último parece ser identificar personagens e "dar voz" aos mitos que estão por trás, que organizam e que dão significado à imagem, tem sido criticado. Urton (2008), por exemplo, critica a maneira como Rowe (op.cit.) alterna exemplos artísticos e literários para explicar o significado dos kennings e outros tropos relacionados, como a símile e a metáfora, mas alegando, ao mesmo tempo, que os exemplos literários são válidos para a representação iconográfica.

De acordo, com Urton (op.cit.), a representação visual de qualquer um dos tropos (símile, metáfora e kenning) pode ser feita apenas por meio da comparação por substituição, mais especificamente, o kenning, uma vez que, caso figurados visualmente, as três figuras de linguagem pareceriam exatamente iguais. Com isto, os exemplos de Rowe onde o cabelo é comparado à cobra, ou seja, a símile "seus cabelos são como cobra", a metáfora "seus cabelos de serpente" e o kenning "seu ninho de cobra", quando figurados, só seria possível ver cabelos representados como cobra.

Estes ícones figurados na iconografia Chavín e interpretados por Rowe (op.cit.) como kennings, devem ser compreendidos em termos de sua organização dentro de um corpo e da composição anatômica deste corpo. Um dos exemplos da cultura Chavín usados por Urton é o da criatura que ele sugere ser o amarus, um ser compósito que pode incorporar partes corporais de caimans (uma espécie de jacaré), felinos, entre outros, e que compõe um eixo iconográfico fundamental do obelisco de Tello. Neste obelisco, tal ser é figurado dentro da estrutura dos corpos de dois caimans, de modo que as suas características são compostas por animais justapostos, assim, por exemplo, um felino / joelho está ligado a um réptil / pulso ou tornozelo (Urton, op.cit.).

Este tipo de composição indicaria certos princípios classificatórios pautados na relação de animais através da justaposição ou contiguidade, ou seja, na metonímia, bem como na comparação metafórica destes animais a certas partes dos corpos, como por exemplo, naquelas em que cotovelos e joelhos (jaguar) e pulsos e tornozelos (serpentes entrelaçadas) são 
transformados em animais. Com isto, os seres compósitos surgidos destas composições sugeririam princípios organizadores, modelos ou paradigmas para organizar e classificar as relações, como por exemplo, ascendência, filiação e afinidade (Urton, 2008:221). Esta abordagem poderia ser extrapolada à sociedade como um todo, já que esta é vista metaforicamente como um corpo, e os corpos são experimentados individualmente, mas são coletivamente socializados (Urton, 2008: 233).

\subsubsection{Os seres do entre-dois.}

Lagrou (2013) pensando nas técnicas perspectivistas de tornar o invisível visível nos grafismos Kashinawa aponta que os grafismos, ao invés de sugerirem figuras estáticas que funcionariam como unidades mínimas de significação, apontam para a relação entre-dois das figuras, haja visto que os seres são vislumbrados a partir da relação entre as linhas. Percebemos na iconografia das tangas a recorrência de certos seres que surgem da relação entre outros seres. Estes são sugeridos por meio da reflexão ou desdobramento de certos grafismos ou surgem da justaposição de certas figuras

Notamos que muitas tangas possuem em seu painel gráfico uma pequena figura que alude a uma pequena "cara". O ser sauroforme descrito anteriormente tem um papel fundamental na configuração desta pequena cara. Como pode ser visto na prancha abaixo (Figura 54), esta pequena face é composta por três áreas: um elemento central de forma amendoada e com linhas duplas pequenas saindo das suas laterais, além de um elemento triangular $^{33}$ que sai das suas extremidades, de modo a formar o cenho, nariz e boca; duas áreas laterais onde, normalmente, há um motivo quadrangular ou um pequeno ponto ou uma pequena linha que compõe os olhos da pequena figura.

\footnotetext{
${ }^{33} \mathrm{Em}$ alguns casos, em cada extremidade deste elemento amendoado pode sair um elemento de formato diferente, como por exemplo, na extremidade superior pode haver um elemento quadrangular ou amendoado, e na inferior, um elemento triangular, conforme pode ser visto nos exemplos da prancha.
} 


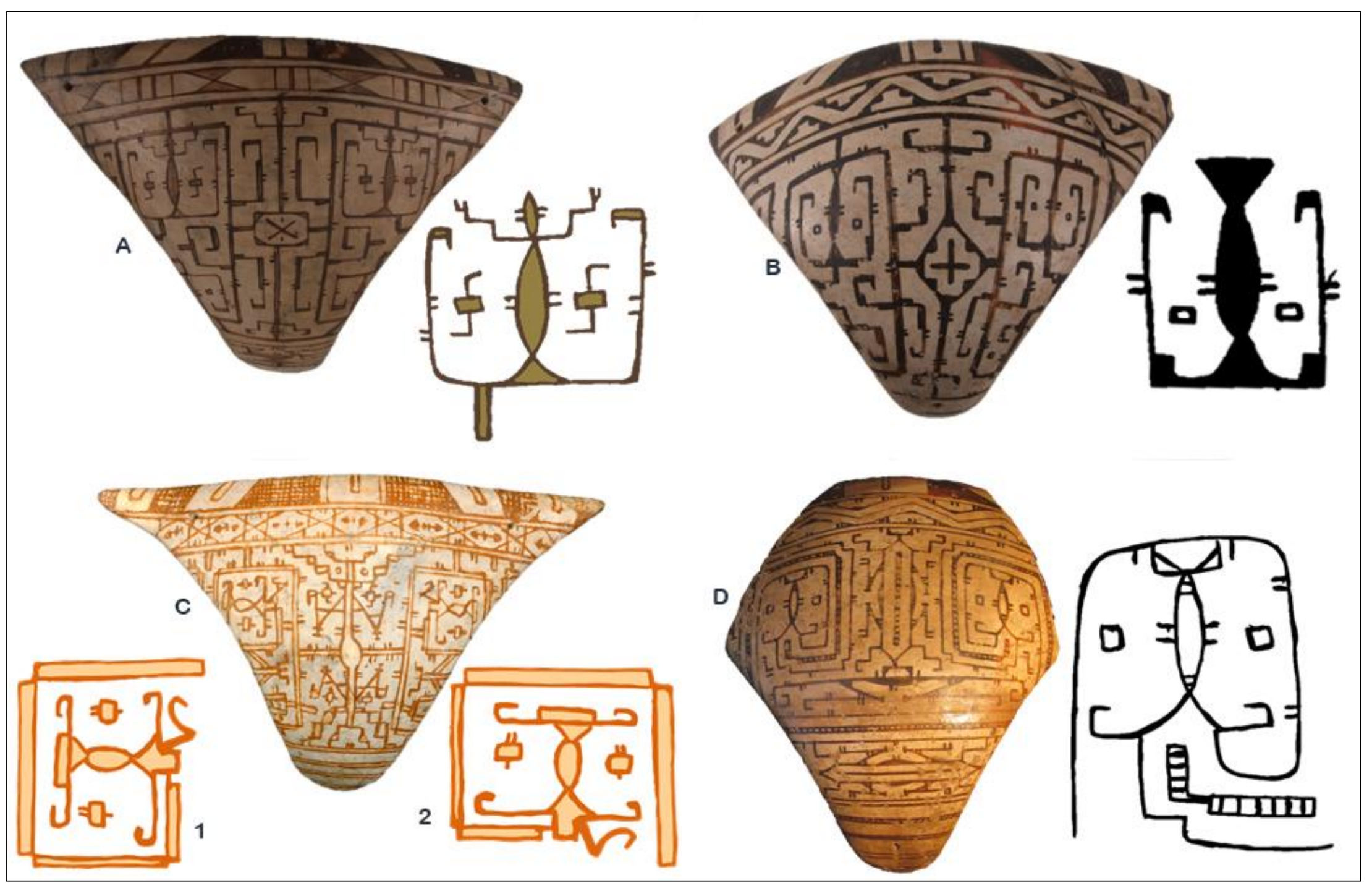

Figura 54 - lagartos/jacarés compondo as pequenas caras que formam os olhos das grandes faces. A e B: Coleção Oliveira, Museu do Estado de Pernambuco, Recife;

C: ICBS/MAE-USP, São Paulo;

D: Museu Paraense Emílio Goeldi, Belém. 
Nota-se que o elemento central frequentemente alude à figura do sauro. Esta pequena figura sauroforme pode ser percebida de maneira mais imediata no exemplo que ilustramos na figura 54A, contudo, é possível perceber que a mesma figura é sugerida nas outras, embora não tão explicitamente, sobretudo, pela presença de seu dorso de formato amendoado e, às vezes, pela sugestão dos seus membros.

Estas pequenas faces bidimensionais também compartilham características com certas figuras tridimensionais modeladas em tigelas e urnas que apresentam características felínicas (Figura 55). Entretanto, é preciso frisar que diferentemente das figurações de possíveis felinos vistas em outras cerâmicas amazônicas, como por exemplo, na cerâmica Guarita, analisada por Oliveira (2016: 253), onde certos elementos como presas e focinhos são priorizados, aqui as características destacadas são outras. As características enfatizadas são o focinho e as vibrissas (bigodes) que saem da linha de contorno da boca, ambos estilizados, e, ao invés das presas, a língua é destacada, ou seja, priorizam-se aqui atributos sensoriais.

Este modo de figuração, que prioriza atributos sensoriais, não é exclusivo da iconografia marajoara. Também na cerâmica tapajônica não é rara a presença de felinos com a língua de fora, e mesmo lambendo seres humanos. Curiosamente, os felinos tapajônicos têm as suas faces estruturadas de modo semelhante ao que vemos na cerâmica marajoara, com o cenho conectado com o nariz em T invertido (Gomes, 2002; Palmatary, 1960), mas ao mesmo tempo, são figurados com as presas expostas, ao modo como Oliveira (op.cit.) percebeu nos grafismos da cerâmica policroma. 

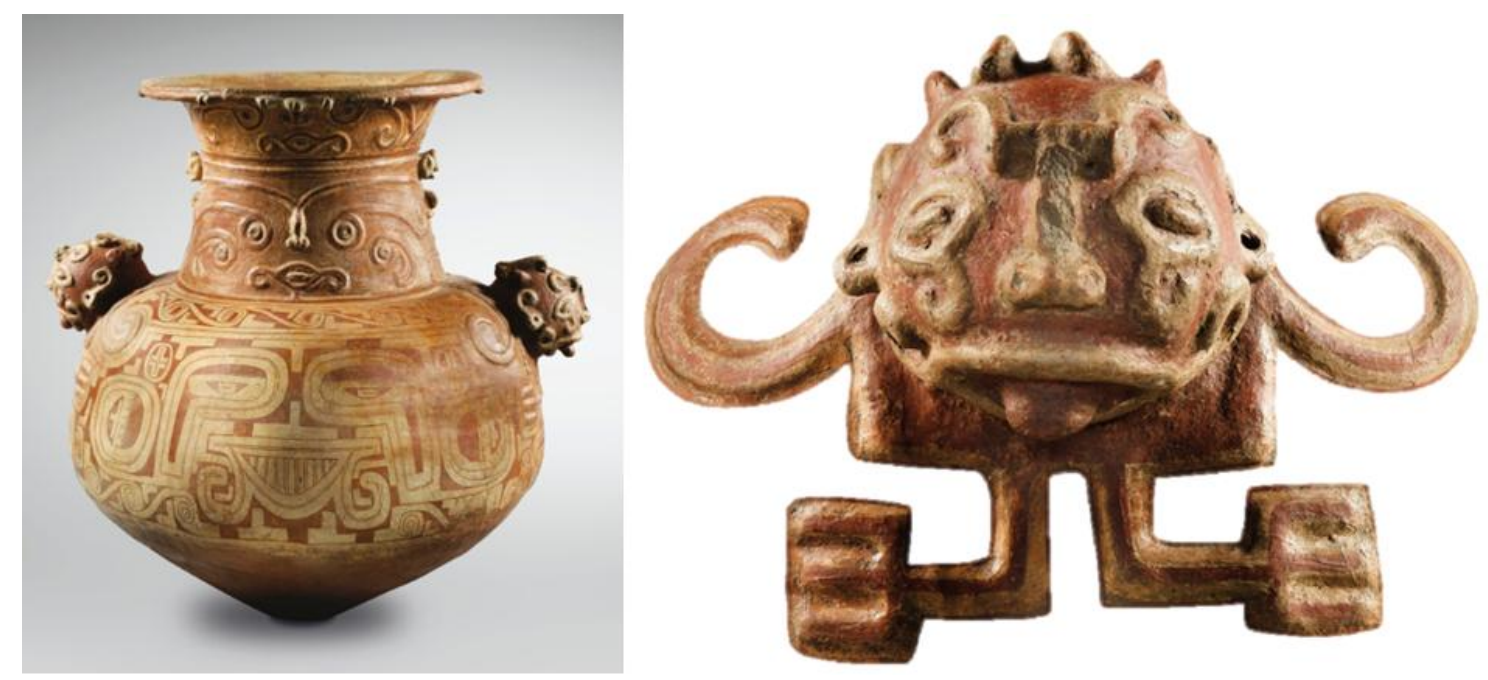

Figura 55- Detalhe mostrando aplique com possíveis traços felínicos. Antiga Coleção Barbier Mueller. Fonte: www.sothebys.com

Nota-se nestes apliques modelados que os traços faciais, assim como nas "pequenas caras" vistas nas tangas, são sugeridos pela introdução de elementos com características sauroformes. Com isto, o elemento sauroforme que sugere o nariz e o cenho funciona como um elemento ordenador a partir do qual outros elementos que compõem os olhos são dispostos. Nota-se que nestas caras pode haver a sobreposição de certos elementos, assim, ao mesmo tempo em que há orelhas com lóbulos alargados, aludindo a uma orelha humana, há também, bem próximo destas, uma orelha de formato mais triangular que poderia indicar uma orelha felínica. Tanto estes apliques quanto as caras figuradas graficamente parecem sugerir transformações, onde a imagem de vários seres são sobrepostas. Com isto, a imagem mescla atributos de um ser com certas características antropomorfas a outro com várias características de seres sauroformes, criando uma imagem intermediária (entre-dois) que parece aludir a um ser felínico.

Alguns apliques modelados, presentes em urnas e vasilhames, apresentam este mesmo tipo de composição, mas mostram outro tipo de transformação. Eles, se vistos de um ângulo, mostram uma figura sauroforme, se visto por outro, a figura sauroforme se transforma em uma face, tais quais as figuras dualistas vistas nas representações tapajônicas, onde, dependendo da posição em que são vistas, mostram humanos ou pássaros. Um exemplo muito interessante deste tipo de transformação é visto em um aplique de urna 
funerária ilustrado por Netto (1885: 384). Conforme Netto (op.cit.) notou, os membros da figura sauroforme funcionam como arcadas superciliares e olhos, enquanto que a cabeça se converte no focinho. Aqui, diferentemente dos exemplos descritos acima, não se vê todas as figuras ao mesmo tempo, mas é necessária a movimentação para ver cada ser, assim, ora se vê um sauro, ora uma cara (figura 56).
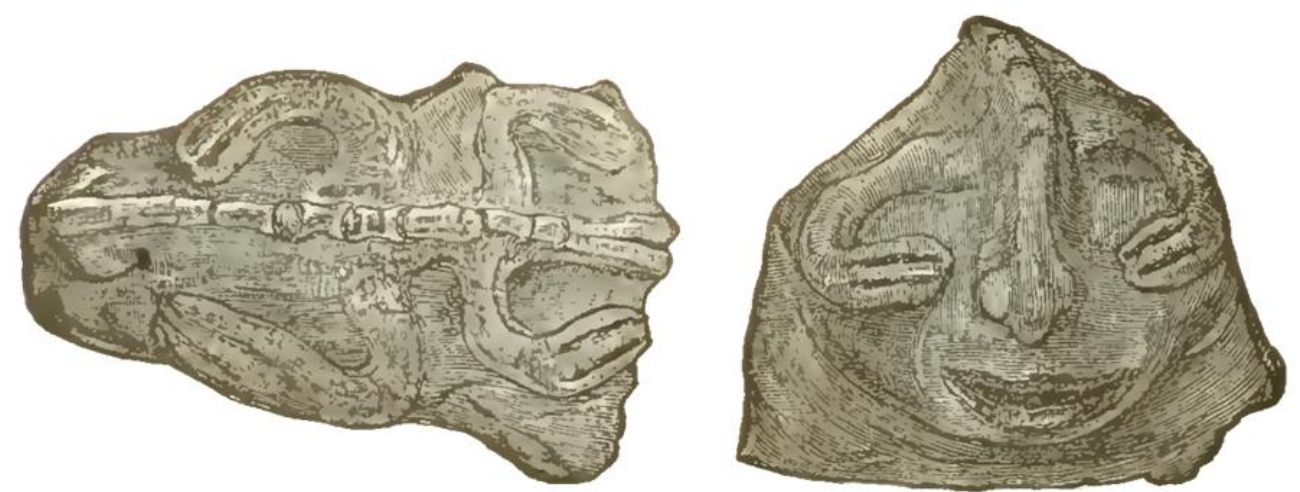

Figura 56- Aplique ilustrado por Netto (1885) que visto por ângulos diferentes mostra duas diferentes figuras.

De toda forma, este modo de figurar, apesar de evocar diferentes tipos de transformações, compartilha da justaposição de figuras como uma técnica de mostrar relações entre seres, de modo que um ser só pode ser vislumbrado através da presença de outro, ou de partes de outro. Estas relações podem ser metonímicas e pautadas em qualidades agentivas dos corpos, que por seu turno, são caracterizados pela fluidez e transformabilidade das formas.

Outro recurso frequente para sugerir a presença de certos seres é o uso de repetições por meio do desdobramento e de movimentos como reflexão, rotação e outros. Aqui, os motivos gráficos podem ser repetidos simetricamente

e estrategicamente de modo a sugerir outras imagens. Um exemplo disto é o motivo "pirâmide escalonada", que, em muitos casos, pode aludir à cabeça do peixe-

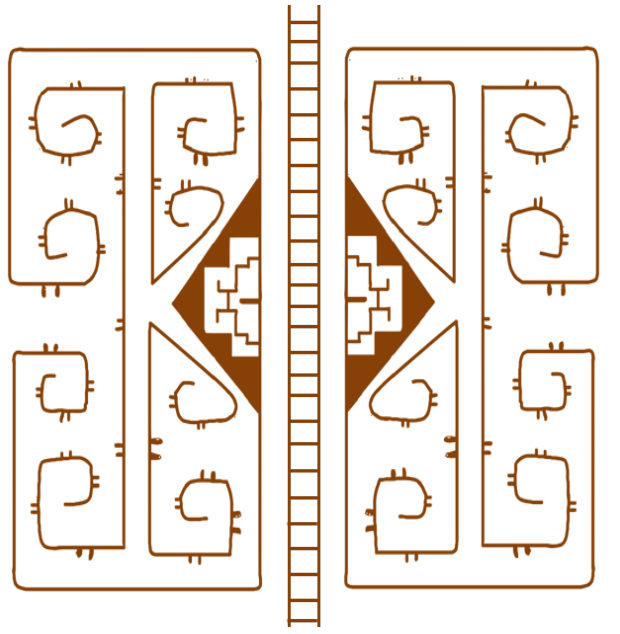

Figura 57. Motivo gráfico que alude à cabeça do peixe-serpentilíneo e, que refletido, aludiria à figura do sauro duplicado 
serpentilíneo (Figura 57), mas que pode ser refletido sugerindo uma figura losangular com volutas, que ao nosso entender aludiria também à figura do sauro com o seu corpo simetricamente duplicado.

Nota-se um tipo de estrutura semelhante às quimeras definidas por Severi (2013) nestas imagens complexas que podem ser decompostas em outras. Conforme já pontuamos no capítulo 2, na arte gráfica de vários povos amazônicos como os Wajana, os Wauja e os Yekuana é comum a representação de um ser complexo que pode se referir ao mesmo tempo a diversos seres. Nota-se nestas imagens quiméricas, como ocorre entre os Wajana, a representação de um determinado ser por meio de temas gráficos que aludiriam às suas possíveis transformações.

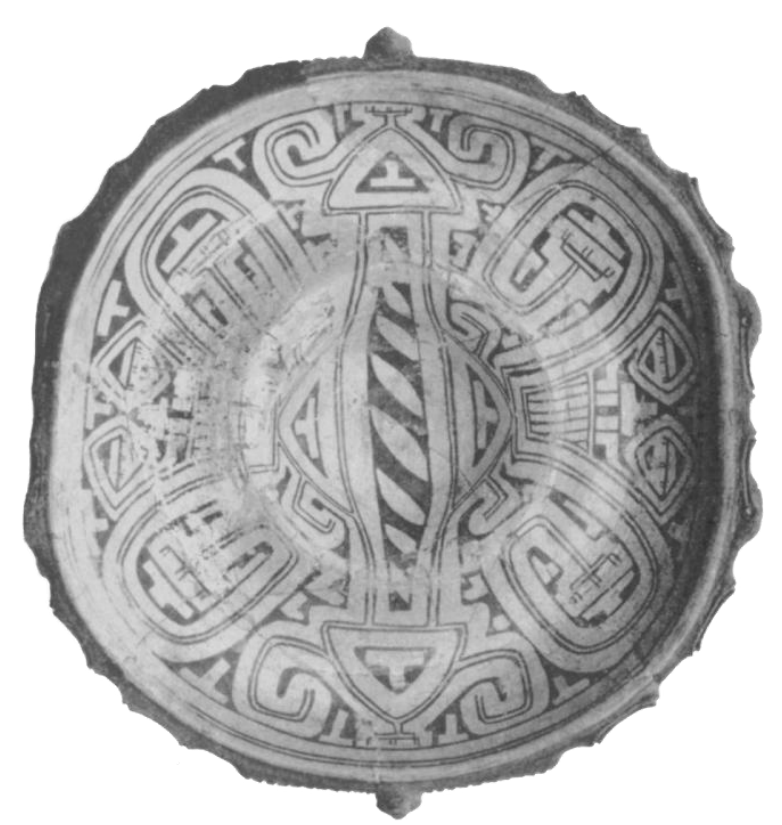

Figura 58. Tigela com figura de peixe-serpentilíneo aludindo à figura do sauro. National Museum of the American Indian. Fonte: Palmatary, 1950.

Especificamente no caso da relação entre 0 peixeserpentilíneo e o sauro, percebemos que na iconografia marajoara não é incomum a figuração de um ser por meio do outro. Em alguns pratos e urnas funerárias, por exemplo, assim como em certos grupos de tangas dos quais iremos tratar em outro momento, o motivo ordenador alude à figura do sauro, contudo em muitos é comum a presença de um ser bicéfalo ou simetricamente duplicado e com características do peixe-serpentilíneo, como o corpo alongado e a cabeça triangular de onde saem volutas, mas com o tronco losangular do sauro sugerido pela cabeça do peixe-serpentilíneo, assim como visto no motivo discutido anteriormente (Figura 58). 
Nos padrões da banda 2 das tangas, a sobreposição de seres é sugerida por procedimentos distintos, relacionados a movimentos simétricos, como a rotação e reflexão alternadas, reflexão, reflexão deslizante, assim como já frisamos anteriormente, sempre sugerindo "faces" com olhos, cenho e nariz, como se pode ver na figura 59 , o que é frequente na maioria das tangas onde esta banda ocorre.

Quando estas "faces" ocorrem, independentemente dos movimentos envolvidos em sua formação, ou seja, que as
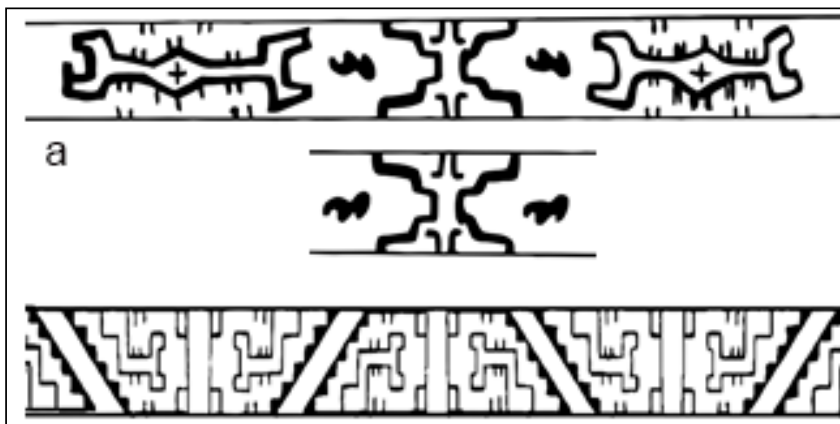
b

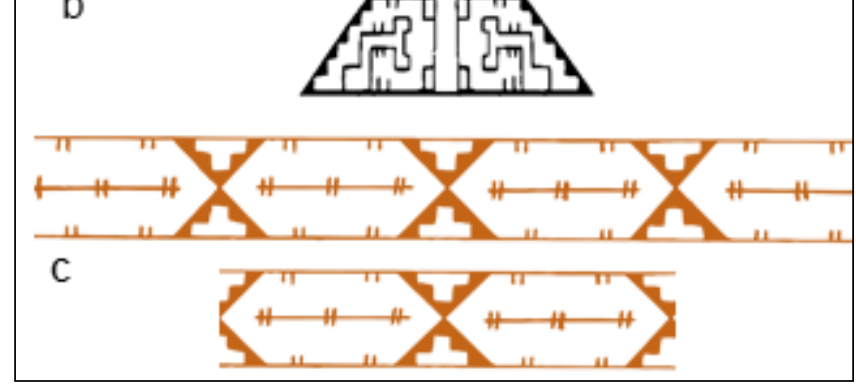

Figura 59- Padrões da banda 2 que formam "caras" a partir de procedimentos distintos.

repetem linearmente, todas elas

são sugeridas a partir do encaixe de certos elementos a partir de um elemento central, cuja posição formal alude à figura do "jacaré-humano" ou "saurohumano", do mesmo modo que ocorre nas pequenas caras vistas anteriormente. Nota-se que estes elementos centrais que aludem ao saurohumano são aqueles que nestas caras sugerem o cenho e o nariz.

\subsubsection{As anatomias compósitas e fluidas}

Desde os primórdios da pesquisa sobre a cerâmica da fase marajoara que os grafismos das tangas chamam a atenção. Hartt (1876: 23), por exemplo, foi o primeiro a observar que os grafismos do painel gráfico compõem uma cara, e por isto sugeriu se tratar da figuração de uma cara humana, o que sabemos, é difícil de especificar na cerâmica marajoara como um todo, que normalmente mostra corpos compósitos ou em transformação.

Conforme mostramos anteriormente, certas figuras se sobressaem nos campos gráficos devido às suas características. Algumas delas aludem a seres específicos e às suas transformações, enquanto outras sugerem certos seres ocultos entre os grafismos. Estes seres, juntos, compõem imagens maiores, 
assim como partes anatômicas compõem um corpo, de modo que a imagem resultante alude a um ser compósito. Notamos nestas imagens um jogo dinâmico caracterizado por uma relação entre parte e todo, onde o todo, na maioria das vezes, alude à figura de uma cara, e cujas "partes" são compostas por seres como sauros, peixes-serpentilíneos e outros. Como resultado deste jogo, o espectador vê várias imagens ao mesmo tempo, assim, uma cara que se abre e desvela outras imagens. Como já destacamos em outro momento, mais recentemente Prous e Lima (op.cit.) perceberam que estas caras podem ser variavelmente indicadas no campo gráfico, podendo ter olhos e bocas, às vezes olhos nariz, boca e orelhas (Figura 60).

A
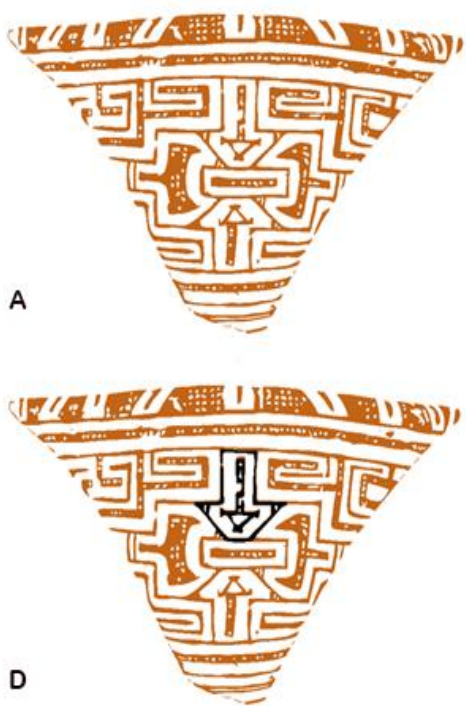

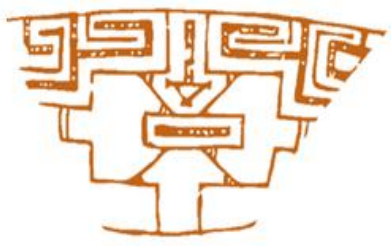

B

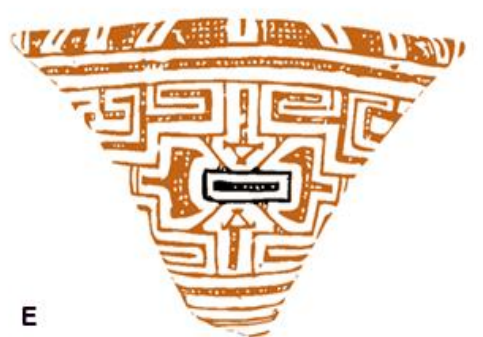

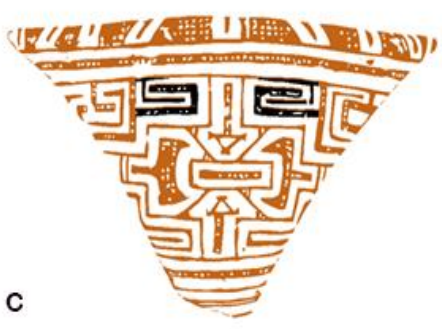

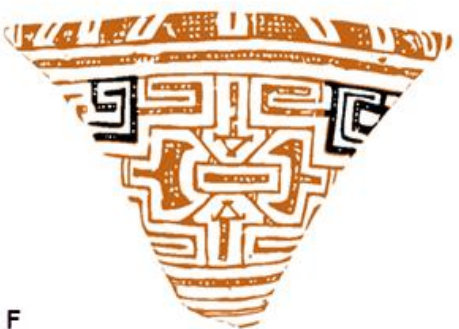

Figura 60- Detalhes destacando as características da cara vista no painel gráfico. Antigo Instituto Cultural Banco Santos- MAE-USP

A- Tanga com painel gráfico aludindo a uma cara.

B- Detalhe da cara figurada no painel gráfico.

C- Detalhe destacando os olhos.

D- Detalhe destacando o nariz.

E- Detalhe destacando a boca.

F- Detalhe destacando as orelhas.

Estas caras podem ser bastante variáveis, sendo que as suas características são determinadas pelos seres descritos anteriormente, pois são eles que compõem traços como olhos, bocas, nariz e orelhas. Vemos um tipo de anatomia compósita que parece aludir àquelas anatomias vistas ainda hoje nas ontologias construtivistas amazônicas, onde o corpo é concebido como uma entidade compósita, criado a partir de vários seres (Santos Granero, 2012), como já discutimos no capítulo 2. 
É muito comum que este tipo de imagem seja figurada também em outros objetos, tais como urnas funerárias, vasilhas, bancos, entre outros. Às vezes ela pode estar presente como parte de um corpo, com tronco, membros sugeridos ou ausentes e cabeças, como visto em urnas funerárias, e em outros casos, como vemos em certas vasilhas, bancos e nas tangas, o corpo todo é sintetizado na forma de uma cara (figura 61).

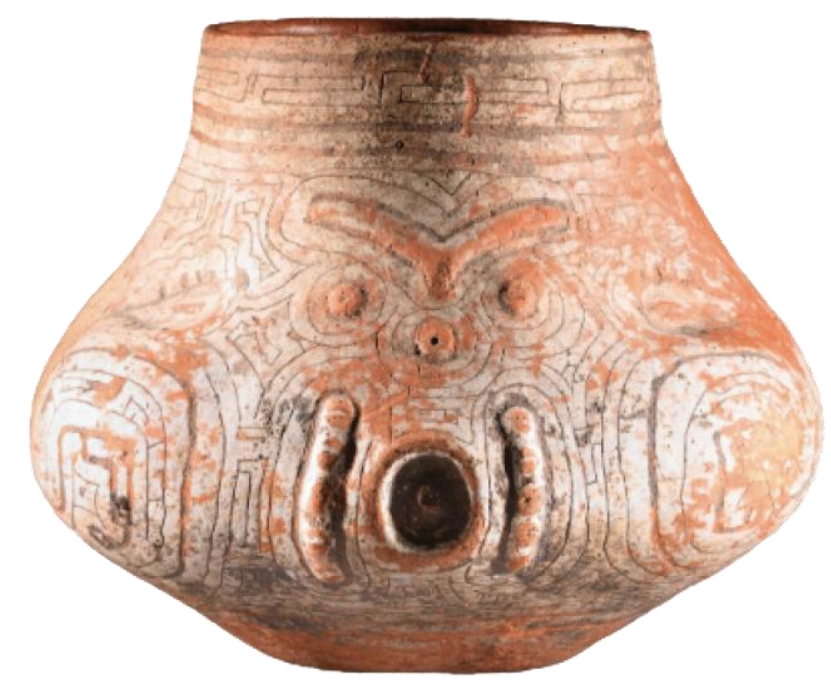

Figura 61 - Vaso que alude à figura de uma cara. Antiga coleção Barbier-Mueller, Geneva. Fonte:Young-Sánchez e Schaan (2011).

Embora as faces marajoaras compartilhem certas características que as tornam reconhecíveis dentro daquele estilo, elas podem ser compostas com traços bastante distintos. Olhos podem ser sugeridos por figuras diversas que ora aludem a escorpiões, ora aludem a sauros; figuras em T's refletidos verticalmente, muitas vezes aludem ao cenho e ao nariz, enquanto linhas arqueadas podem sugerir arcos supraciliares ou sobrancelhas; a boca pode ser sugerida por figuras diversas que muitas vezes aludem a sauros, assim como por figuras circulares e por figuras quadrangulares, espirais, etc. Também se nota que certas características faciais podem ser bem marcadas, como por exemplo, as bochechas podem ser delimitadas por espirais e, em casos específicos, por figuras que aludem a seres.

Ladislau Netto (1885) já havia chamado a atenção sobre o enfoque dado às caras na cerâmica marajoara, seja por meio da modelagem, da incisão ou excisão ou por meio da pintura. Nota-se que estas caras quando figuradas por 
qualquer uma destas técnicas podem ser decompostas em seres e partes de seres, como já observamos. Aliás, como já observado por Barreto (2014), na cerâmica marajoara este é um modo paradigmático de figurar o corpo. Aqui, em certos tipos de urnas, como aquelas do tipo Pacoval Inciso o corpo é construído a partir de seres diversos, com olhos que aludem a escorpiões e braços serpentilíneos, enquanto em outros casos, o corpo é composto por figuras que foram tão manipuladas que é difícil de relacionar a um protótipo especifico.

Este modo de figurar o corpo não é restrito somente à cerâmica da fase marajoara. Corpos compósitos caracterizados por braços serpentilínios são vistos também nas urnas da tradição Policroma e, além disto, os campos iconográficos de certos vasos podem ser caracterizados por padrões que aludem a seres antropomorfos, sugerindo, ao mesmo tempo, outros seres, como felinos e aves (Oliveira, op.cit.).

Especificamente em relação às tangas, estas caras podem apresentar características muito peculiares, misturando sempre traços antropomorfos com corpos e partes de animais, e podem ser compostas por atributos como olhos, nariz, boca e orelhas, cenho, bigodes (que poderiam ser também barbilhos ou vibrissas), e em certos casos, junto às orelhas pode haver também um elemento que pode ser interpretado como um adorno auricular. Entretanto, tais atributos jamais são sugeridos diretamente, mas sim por meio da sobreposição, onde os olhos podem ser indicados por meio de pequenas caras, e estas, conforme já mostramos em outro momento, aludem a um ser sauroforme, ou pela cabeça do peixe-serpentilíneo, etc., figuras sauroformes podem ser dispostas verticalmente no meio da composição, entre as duas pequenas caras, indicando o cenho, a linha e a base do nariz, e em casos mais específicos, a mesma figura é disposta horizontalmente, mais abaixo do nariz, sugerindo uma boca (figura 62). 

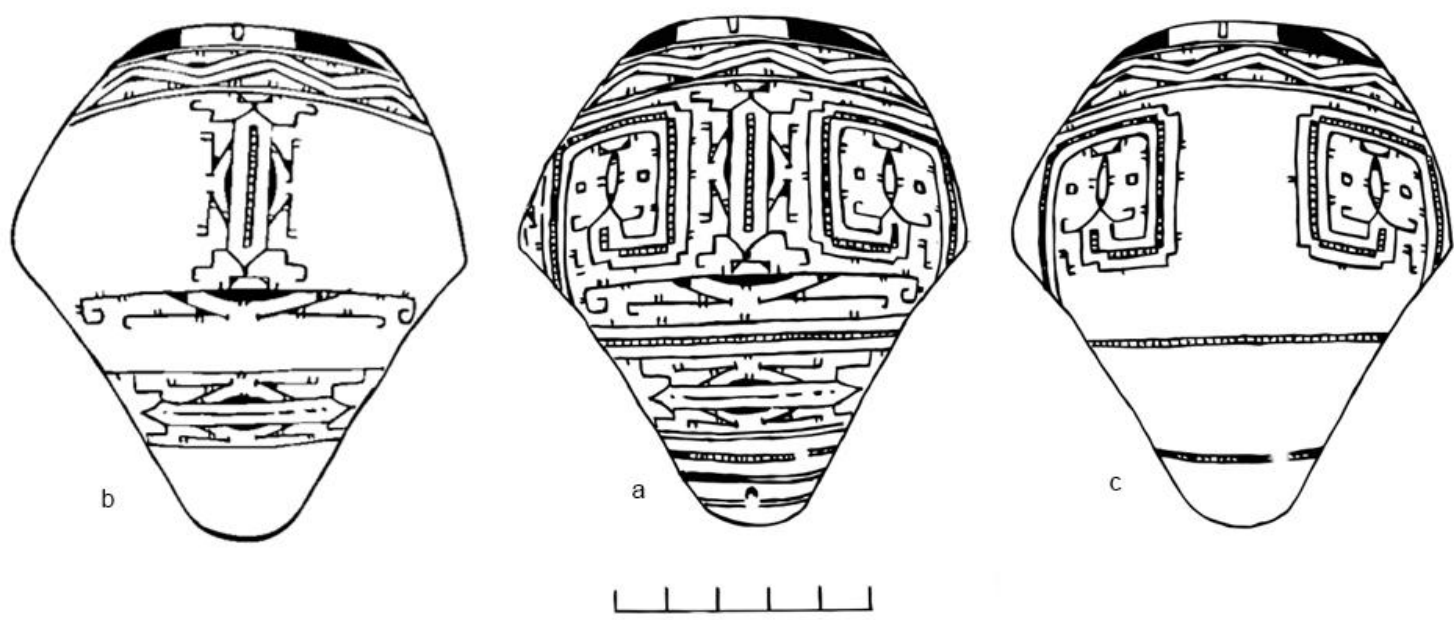

Figura 62- llustração de tanga com as extremidades superiores ausentes mostrando uma cara. Museu Paraense Emílio Goeldi.

a- Cara cujas partes são compostas por seres diversos.

b-Cenho, nariz, bigodes e boca compostos por um ser que alude a um sauro.

c- Olhos sugeridos por cara pequena que, por sua vez, é composta a partir de uma figura sauroforme.

\section{Enquadramento para fazer ver}

Estas faces podem ser compostas a partir de um conjunto de técnicas que envolvem o recorte dos motivos empregados e também movimentos como reflexão, translação, rotação, etc. O recorte dos padrões e motivos é umas das características mais comuns na composição das imagens das tangas. Conforme já comentado, esta é uma técnica vista ainda hoje na arte gráfica de vários povos da Amazônia (Lagrou, op.cit.). Entre os Asurini, por exemplo, o recorte dos padrões e motivos que são aplicados nos corpos cerâmicos sugere a sua continuidade além dos limites do suporte, o que foi caracterizado por Muller (1992) como "janela ao infinito".

Esta característica, para Lagrou (op.cit.) é uma maneira de jogar com a tensão entre visibilidade e invisibilidade. Isto parece bastante interessante, em relação aos padrões que aludem a caras com os quais estamos lidando, principalmente, por que eles sugerem a sua continuidade além dos limites do suporte. Todos os movimentos que já discutimos em outro momento estendem os padrões que compõe a imagem vista virtualmente para as laterais esquerda e direita, ao modo dos padrões de bandas. Isto sugere que os padrões do painel gráfico das tangas são potencialmente padrões allover, pois eles 
continuam se repetindo por meio de um jogo de movimento diversos em um plano virtual, ao modo das quimeras abstratas ameríndias (Figura 63).

Esse recorte que promove uma "janela ao infinito" tem um papel crucial na composição das faces vistas no painel gráfico, pois estas figuras são o resultado de um enquadramento específico em uma malha infinita de motivos gráficos que aludem a seres específicos. Este enquadramento que possibilita focar o olhar sobre uma imagem que pode ser abrir em um plano virtual, assim como visto nas artes dos povos amazônicos, poderia ser considerado como uma técnica de mediação entre o visível e o invisível (Lagrou, op.cit.).

Tais padrões de rede virtuais são compostos a partir de motivos gráficos que aludem a seres específicos ou à combinação destes seres, e são deslocados a partir dos movimentos diversos já explicitados. Estes movimentos são responsáveis pelo encadeamento da imagem, permitindo que a partir da repetição de duas figuras seja possível desvelar uma imagem oculta, ou mais especificamente, uma cara. Nos padrões de rede o responsável por enquadrar esta figura que alude a uma face, é o olhar, ao se focar em um ponto específico entre as repetições de um motivo gráfico que compõe uma imagem. Aqui, ao modo das quimeras abstratas ameríndias (Lagrou, op.cit.), os grafismos poderiam aludir a transformações, mostrando seres específicos e as suas transformações em outros seres. Com isto, o enquadramento da imagem de uma cara poderia ser entendido como um modo de estabilizar imagens que são demasiadamente instáveis e fluídas.

Este recorte que permitiria estabilizar uma imagem a partir de uma cadeia de transformações infinitas de figuras aludindo a seres específicos, entretanto, nunca é completamente estável. Se por um lado, o enquadramento que possibilita ver uma imagem ou um ser do "entre-dois", entre um motivo gráfico e outro de uma grande rede gráfica, cessa as transformações do padrão allover potencial, por outro lado, a imagem que é enquadrada tem sua própria instabilidade. Ela é composta por outras figuras que revelam outras figuras, ou seja, há um jogo de transformações dentro da própria imagem que é enquadrada. 


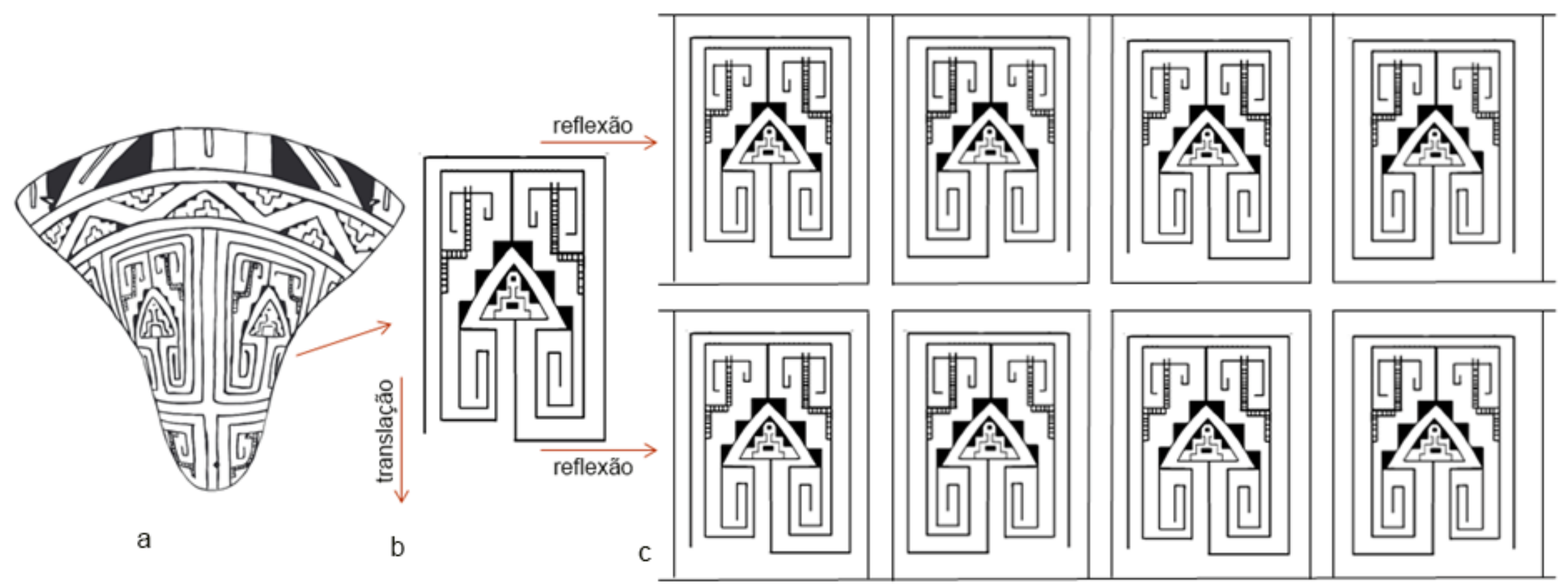

Figura 63- Figura 18- Imagem que alude a uma cara composta no painel gráfico a partir do enquadramento em um ponto específico de um padrão allover virtual. Tanga antiga coleção Barbier-Mueller, Geneva.

a- Tanga com face figurada no painel gráfico.

b-motivo gráfico que é repetido por meio de movimentos simétricos para a formação de padrão gráfico que alude a face.

c- Padrão allover virtual ou continuação dos motivos gráficos interrompidos que sugerem uma "janela ao infinito". 
Nos padrões da banda 2, já descritos anteriormente, ocorre o

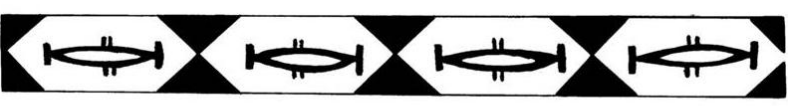
contrário. Como já comentado, estes padrões são repetidos linearmente por meio de movimentos diversos, sugerindo uma cara com cenho, olhos e às vezes, nariz entre os seus elementos. Contudo, esta cara nunca é explicita, a sua presença é apenas sugerida, é o olhar que a
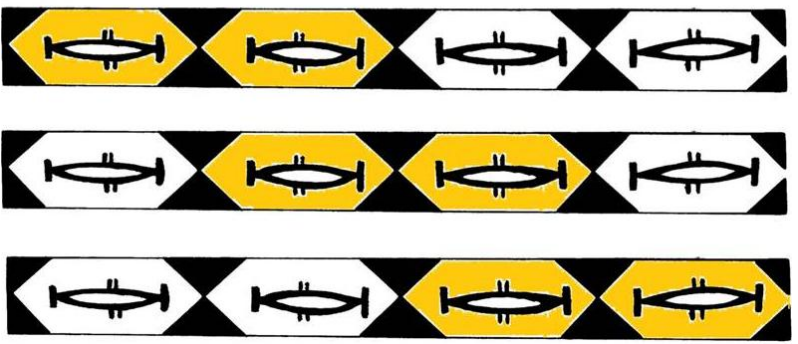

Figura 64- Detalhe de padrão da banda $2 \mathrm{com}$ faces ocultas destacadas em amarelo. Neste caso, os triângulo refletidos aludem ao cenho e ao nariz, enquanto que o espaço hexagonal entre cada repetição dos triângulo refletidos, assim como o motivo gráfico em seu interior, aludem aos olhos.

enquadra, diferentemente do que é visto no painel gráfico, onde a cara é desvelada por meio de um recorte, o que pode ser entendo como uma técnica para capturar o olhar do observador.

Figuras em escalas múltiplas e fractalidade

Este perpétuo estado de transformação das imagens poderia ainda ser intensificado pela composição multi-escalar das figuras, por meio de figuras semelhantes, mas em escalas diferentes, como por exemplo, uma cara menor dentro de uma cara maior, ao modo das imagens fractais de Gell (op.cit.), e ainda, por meio de esquemas compositivos evolvendo encaixes múltiplos, ao modo das bonecas russas, como visto em Fausto (2013) na composição de certas máscaras da Colúmbia-Britânica e do Alasca, na Costa noroeste na América do Norte, e do Alto Xingu, na Amazônia.

No decorrer desta pesquisa, observamos que as figuras podem ser elaboradas por meio da composição multi-escalar, de modo que a cara figurada no painel gráfico, frequentemente, possui imagens de caras em menor escala em seu interior, em uma relação de hierarquização, nos termos de Gell (op.cit). Esta hierarquização é bem comum na cerâmica marajoara como um todo e bem frequente nas tangas, onde motivos menores que aludem a seres específicos podem formar figuras maiores. Estas figuras podem ainda compor os olhos da figura e, mais raramente, as orelhas, contudo, é comum que 
componha a figura do sauro-humano indicando a sua cabeça e o seu dorso, a partir da reflexão destas figuras.

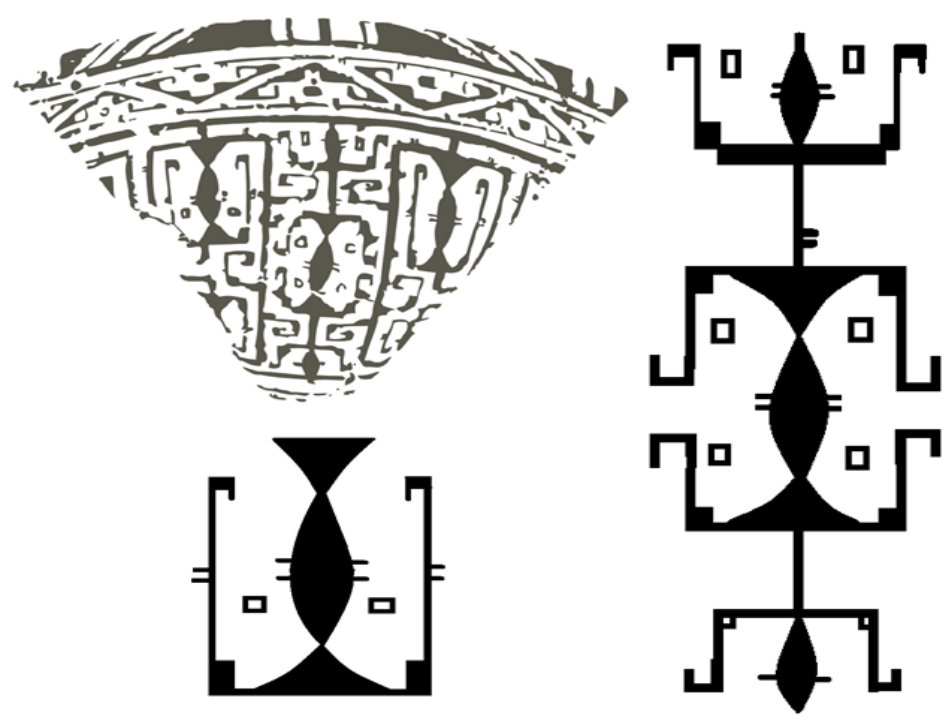

Figura 65- Figuras que aludem a faces na composição da imagem do painel gráfico. Tanga redesenhada a partir de Meggers e Evans, 1957.

Esta hierarquização pode ainda ser percebida na relação dos padrões da banda 2 com os padrões do painel gráfico, que apresentam temas que aludem a transformação de seres, no caso dos padrões da banda 2, de seres que se transformam em outro ser que nunca se mostra por completo, mas só a sua cara, e no caso do painel gráfico, de um ser que também só mostra a sua cara, mas que se transforma em vários outros seres, que também podem se transformar em outros. 

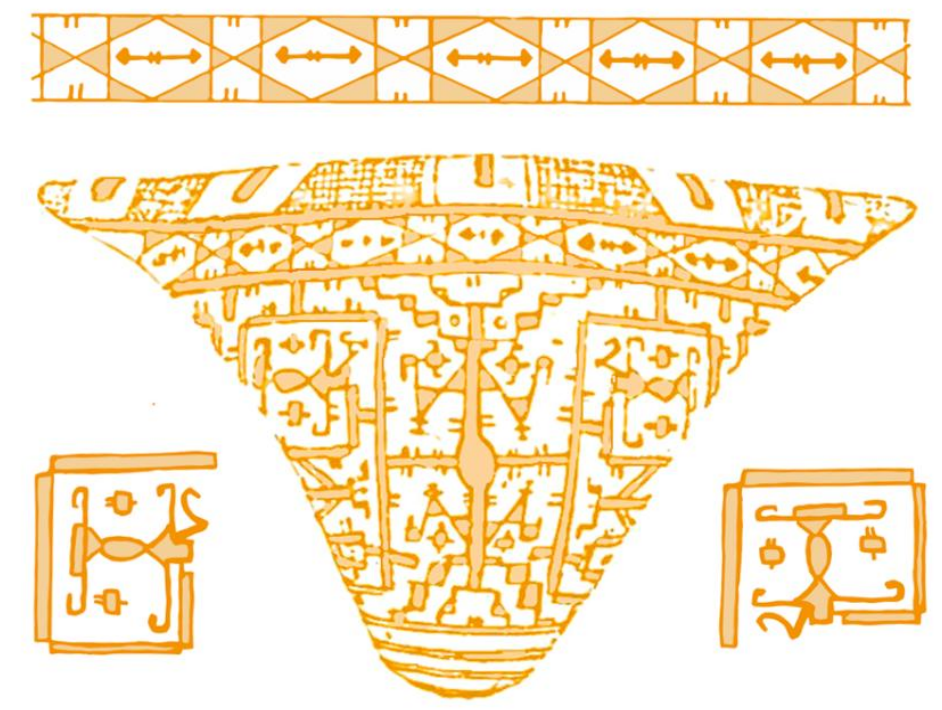

Figura 66- Relação multi-escalar vista na sobreposição de figuras que aludem a faces em escalas diferentes. Nota-se caras menores na composição dos olhos da cara maior, no painel gráfico e, pequenas caras "virtuais" no padrão da banda 2.

A mesma hierarquização vista em relação à escala destas figuras existe também na maneira de estruturá-las, sempre a partir de três componentes, sendo um central e dois laterais, independentemente da escala em que sejam feitas (figura 67). Em todas elas, sejam figuradas no painel gráfico ou nos padrões da banda 2, sempre os "olhos" são dispostos nas laterais de um motivo ou elemento ordenador que funciona como cenho, nariz ou boca. É interessante notar que os motivos ou elementos ordenadores que compõe estas figuras, sejam dos padrões de banda, sejam do painel gráfico, apresentam a mesma posição formal, e parecem aludir ao sauro-humano, ou seja, há figuras feitas de formas diferentes e em escalas diferentes, mas com semelhanças formais que podem aludir ao mesmo ser. 


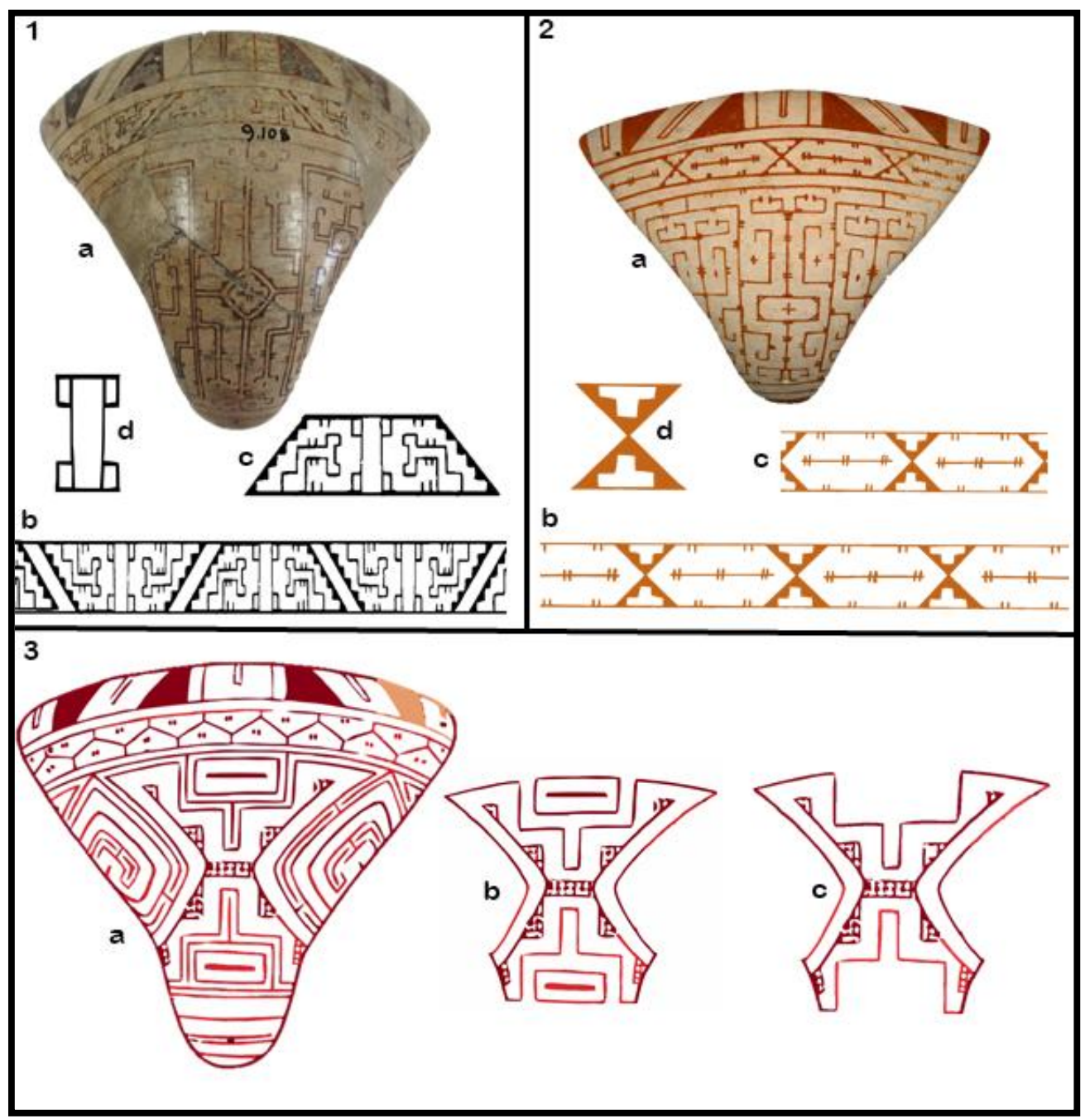

Figura 67- Hierarquização vista na maneira de estruturar as figuras.

Esta relação multi-escalar das imagens, seja por meio de figuras em escalas diferentes, seja pelo uso do mesmo procedimento para estruturar figuras diferentes ou em escalas diferentes pode ser compreendida a partir da noção de imagem fractal, conforme proposto inicialmente por Gell (op.cit.), e desenvolvida a partir da noção de pessoa fractal de Wagner (1991), já discutidas mais profundamente no capítulo 2. Lembramos que esta noção equivaleria a uma figura de linguagem, ou um tropo, para a expressão da noção de pluralidade singular e singularidade plural, e assim, as partes que compõe um corpo e um corpo as partes que o compõe estão integralmente implicados em relações multi-escalares.

As imagens fractais, mais especificamente, são compostas por figuras em escala menor que replicam as mesmas relações vistas na imagem como 
um todo, ou seja, as partes e o todo possuem as mesmas propriedades, por isto, tais figuras poderiam ser uma metáfora para expressar as relações sociais, tais como visto por Gell (op.cit.) na figura do A’a, uma imagem da tradição Rurutan, da Polinésia, que seria um tropo relacionado à sociedade, e as partes que a compõem se relacionariam às suas unidades de parentesco que estruturam a sociedade.

Esta relação dialética entre o corpo e as partes que o compõem é bastante proeminente, sobretudo, nas sociedades ameríndias da Amazônia onde a pessoa é constituída a partir da incorporação do outro em diferentes escalas, mas sempre semelhantes umas às outras (Santos Granero, 2012: 31), o que implicaria em ontologias estruturadas a partir da lógica da predação, conforme comentado no capítulo 2. Até agora mostramos como as imagens vistas nas tangas são compostas a partir do encaixe recursivo de figuras em escalas diferentes que aludem a diferentes seres em transformação permanente. Esta fractalidade ameríndia que se dá a partir da incorporação do outro poderia ser traduzida em termos visuais, na Amazônia, por meio das imagens multicompostas, cujos corpos são constituídos por diversos seres ou partes deles.

Esta fractalidade, no caso das tangas, vista no encaixe múltiplo das figuras que compõem as imagens, alude a seres em transformação em diferentes escalas. Se por um lado, a figura que sugere uma face composta por seres diversos indica um corpo em transformação, por outro lado, os seres que a compõem também estão em transformação. Estas diferentes escalas de transformação poderiam ser entendidas como uma maneira de levar a instabilidade das formas a níveis cada vez mais profundos, de modo que o enquadramento de uma imagem a partir de um padrão allover virtual, ao cessar a cadeia de transformações que se dá em um plano infinito e horizontal, poderia priorizar uma cadeia transformativa em um plano vertical, isto é, para dentro da imagem. Com isto, a imagem, ao modo das imagens quiméricas, se abriria paulatinamente, revelando uma cadeia de imagens em transformação cada vez mais profunda com o poder de abduzir o expectador para dentro destes grafismos labirínticos. 


\section{CAPÍTULO 5}

\section{CORPOS-IMAGENS: OS GRUPOS DE TANGAS}

\section{Giviting}

No capítulo anterior nos focamos nas principais características estruturais das tangas, como por exemplo, a delimitação dos seus campos gráficos e a elaboração dos seus padrões gráficos, e, além disto, alguns aspectos iconográficos foram destacados com a identificação de certos seres recorrentes na composição das imagens. Um enfoque especial foi dado às técnicas perceptivas envolvidas na composição das imagens vistas, sobretudo, àquelas capazes de mostrar transformações e revelar imagens ocultas. Deste ponto em diante, nos focaremos na descrição dos conjuntos formados a partir das características comentadas até aqui.

A análise identificou uma variabilidade nos princípios estruturais das imagens compostas nas tangas, de modo que nove conjuntos foram formados. Deste modo, das 210 tangas analisadas, 172 foram agrupadas nestes conjuntos. Já as outras 36, apesar de apresentar alguns indícios de linhas estruturais, não puderam ser incorporadas em virtude da perda de policromia no painel gráfico que impossibilitou a análise dos grafismos.

\begin{tabular}{|c|c|}
\hline \multicolumn{2}{|c|}{ Grupos Formados } \\
\hline Grupo & Número de tangas \\
\hline Grupo 1 & 50 \\
\hline Grupo 2 & 29 \\
\hline Grupo 3 & 11 \\
\hline Grupo 4 & 19 \\
\hline Grupo 5 & 14 \\
\hline Grupo 6 & 14 \\
\hline Grupo 7 & 13 \\
\hline Grupo 8 & 9 \\
\hline Grupo 9 & 15 \\
\hline Não classificadas & 36 \\
\hline
\end{tabular}


Entre as tangas do grupo 1, as imagens são elaboradas por meio do encaixe de diversas figuras, ao modo das bonecas russas. Isto é muito interessante, por que o espelhamento dos padrões destas tangas não engendram novas imagens na junção entre eles, sugerindo que as principais transformações das imagens são aquelas ocorridas diante dos olhos, ou seja, nos grafismos dispostos nos painéis gráficos. Considerando-se que este conjunto é aquele com a maior quantidade de tangas, abrangendo quase um quarto das peças, e que possui uma ampla dispersão pelos sítios da fase marajoara, é possível que os recursos gráficos empregados na elaboração das imagens integrassem uma linguagem menos codificada e mais acessível, mais pautada nas transformações mostradas a "olhos nus" na própria imagem, sem necessariamente precisar recorrer a inferências visuais e à abdução da agência.

As tangas do grupo 2 apresentam algumas semelhanças com aquelas do grupo 1. As imagens elaboradas em seu painel gráfico são também estruturadas dentro de painéis verticais e, inclusive, alguns motivos empregados nestas imagens aludem aos mesmos seres, como por exemplo, sauros e motivos que sugerem pequenas faces, no entanto, os seus painéis gráficos são menores e reduzidos à parte inferior da tanga, diferentemente daquelas. Nestas tangas, é o padrão da banda 2 que ocupa a área central, sendo que as suas elaborações são responsáveis por capturar e prender 0 olhar em seu emaranhado de grafismos, revelando seres como sauros, além de figuras de faces, algumas inclusive, aludindo a seres felínicos.

No grupo 3 , as imagens compostas nas tangas são sempre compostas por motivos aludindo ao peixe-serpentelíneo que, desdobrados, criam uma figura de face. Os padrões vistos aqui, no entanto, quando replicados em um plano virtual, na junção entre cada um, revelam outra figura de face, completamente diferente daquela vista na imagem "física".

As tangas dos grupos 4,5 e 6, embora estruturalmente diferentes, apresentam características gerais semelhantes. Em todas elas há a recorrência de motivos aludindo ao peixe-serpentelíneo ou a seres serpentelíneos que são reordenados para sugerir a figura de seres sauromorfos.

As tangas do grupo 7, por seu turno, apresentam imagens compostas por variações do mesmo motivo. No entanto, é a maneira de recortar e 
enquadrar o padrão que diferencia estas imagens. Aqui, as imagens produzidas destacam partes diferentes do padrão, ora priorizando o motivo que é desdobrado, ora priorizando mostrar a imagem que é formada entre eles, ou ainda, pode recortar o motivo e mostrar apenas uma parte sua, ou seja, há um jogo visual pautado na revelação e ocultação de imagens.

Já as tangas do grupo 8 são elaboradas por variantes de um mesmo motivo que alude à figura do sauro, compondo imagens de faces, cujos atributos nem sempre são perceptíveis. Deste modo, certas características faciais, como cenho, nariz e boca, muitas vezes são apenas sugeridas por meio da relação entre uma figura e outra.

Por fim, nas tangas do grupo 9, as imagens são construídas pela repetição de motivos, de modo que várias figuras podem ser vistas entre as repetições, ao modo dos padrões da banda 2. As tangas deste grupo, não apresentam o padrão da banda 2, uma vez que o mesmo tipo de imagem construída naqueles padrões são elaboradas no painel gráfico.

\subsection{As tangas do Grupo 1}

Este grupo é aquele que apresenta a maior quantidade de tangas, abrangendo um total de 50 inteiras ou fragmentadas e mais 11 fragmentos. É também aquele que apresenta a maior dispersão pelos sítios da fase marajoara, por esta razão há exemplares deste grupo em quase todas as coleções analisadas.

As instituições que guardam coleções com as tangas analisadas deste grupo são as seguintes: 


\begin{tabular}{|c|c|c|c|}
\hline \multicolumn{4}{|c|}{ Tangas do grupo 1 } \\
\hline \multirow{2}{*}{ Coleção/Instituição } & \multicolumn{2}{|c|}{ Quantidade } & \multirow{2}{*}{ Procedência } \\
\cline { 2 - 3 } & Inteira & Fragmentos & \\
\hline ICBS-MAE/USP & 8 & & Tesos Camutins/Urubu \\
\hline MAE-USP & 4 & 2 & Pacoval \\
\hline $\begin{array}{c}\text { Museu Paraense Emílio } \\
\text { Goeldi }\end{array}$ & 3 & & Pacoval \\
\hline $\begin{array}{c}\text { Coleção Dita } \\
\text { Acatauassu/ Museu } \\
\text { Paraense Emílio Goeldi }\end{array}$ & 3 & & Indeterminada \\
\hline $\begin{array}{c}\text { Museu do Estado de } \\
\text { Pernambuco }\end{array}$ & 18 & 5 & Pacoval \\
\hline Museu Nacional & & & Indeterminada \\
\hline
\end{tabular}

Outras instituições cujas coleções abrangem tangas deste grupo e que incorporamos, por meio de fotografias, são:

\begin{tabular}{|c|c|c|}
\hline Coleção Instituição & Quantidade & Procedência \\
\hline Museu do Marajó & 1 & Indeterminada \\
\hline Museu Rocha Santos & 1 & Pacoval \\
\hline Denver Art Museum & 1 & Indetermindo \\
\hline Museu Etnográfico de Geneva & 1 & Pacoval \\
\hline $\begin{array}{c}\text { American Museum of Natural } \\
\text { History }\end{array}$ & 2 & Pacoval e teso Camutins \\
\hline $\begin{array}{c}\text { Museu do Instituto Histórico e } \\
\text { geográfico de Alagoas }\end{array}$ & 1 & \\
\hline $\begin{array}{c}\text { National Museum of American } \\
\text { Indian }\end{array}$ & 3 & \\
\hline
\end{tabular}

Além das tangas mencionadas na tabela acima, não conseguimos identificar as instituições nas quais estão depositados dois exemplares ilustrados em Netto (1885). ${ }^{34}$

Com base na documentação das coleções analisadas, bem como com base na bibliografia publicada (Figueiredo, 1956; Lange, 1914; Mordini, 1929; Palmatary, 1950; Troufflard, 2010) conseguimos levantar a procedência de 21

\footnotetext{
${ }^{34}$ Há ainda uma tanga deste grupo na coleção Landmann, depositada no Museu de Arte de São Paulo, e outra na Coleção Tom Wildi, depositada no Museu de Antropologia da Universidade de Santa Catarina, em Florianópolis, ambas não foram incorporadas em nossa análise.
} 
tangas, ou seja, $42 \%$ das tangas deste grupo, além de seis fragmentos, o que é bastante significativo tendo em vista as condições nas quais as coleções foram formadas.

Diante disto foi possível perceber que as tangas deste grupo não estão restritas a um sítio ou região específicos do domínio marajoara, mas sim possuem uma ampla dispersão regional, conforme mostra o mapa ilustrado abaixo (Figura 68). Como é possível observar na tabela abaixo e no mapa que se segue, estas tangas estão distribuídas desde os sítios do conjunto Os Camutins, região do Rio Anajás, passando pela região do lago Arari, principalmente, no teso Pacoval, onde diagnosticamos o maior número de tangas deste grupo, se estendendo ao teso Pacoval dos Mello, ao sul do lago Guajará, como é possível perceber na tabela abaixo.

\begin{tabular}{|c|c|c|c|}
\hline \multicolumn{4}{|c|}{ Distribuição das tangas do Grupo 1 pelos sítios da fase marajoara } \\
\hline \multicolumn{2}{|c|}{ QUANTIDADE } & \multirow{2}{*}{ PROCEDÊNCIA/ SÍTIO } & \multirow{2}{*}{ INSTITUIÇÃO/COLEÇÃO } \\
\hline Inteira & Fragmentos & & \\
\hline 2 & & Teso Belém & NMAI \\
\hline 8 & & Tesos Camutins/Urubu & $\begin{array}{l}\text { ICBS-MAE/USP (Cols. } \\
\text { Luíz Otávio e Graciete). }\end{array}$ \\
\hline 10 & 4 & Teso Pacoval & $\begin{array}{l}\text { MEPE, AMNH, MPEG, } \\
\text { MIHGAL, NMAI, MRS }\end{array}$ \\
\hline \multirow[t]{2}{*}{1} & & $\begin{array}{c}\text { Fazenda Diamantina } \\
\text { (L. Ariri) }\end{array}$ & NMAI \\
\hline & 2 & Pacoval dos Mello & MAE/USP \\
\hline
\end{tabular}




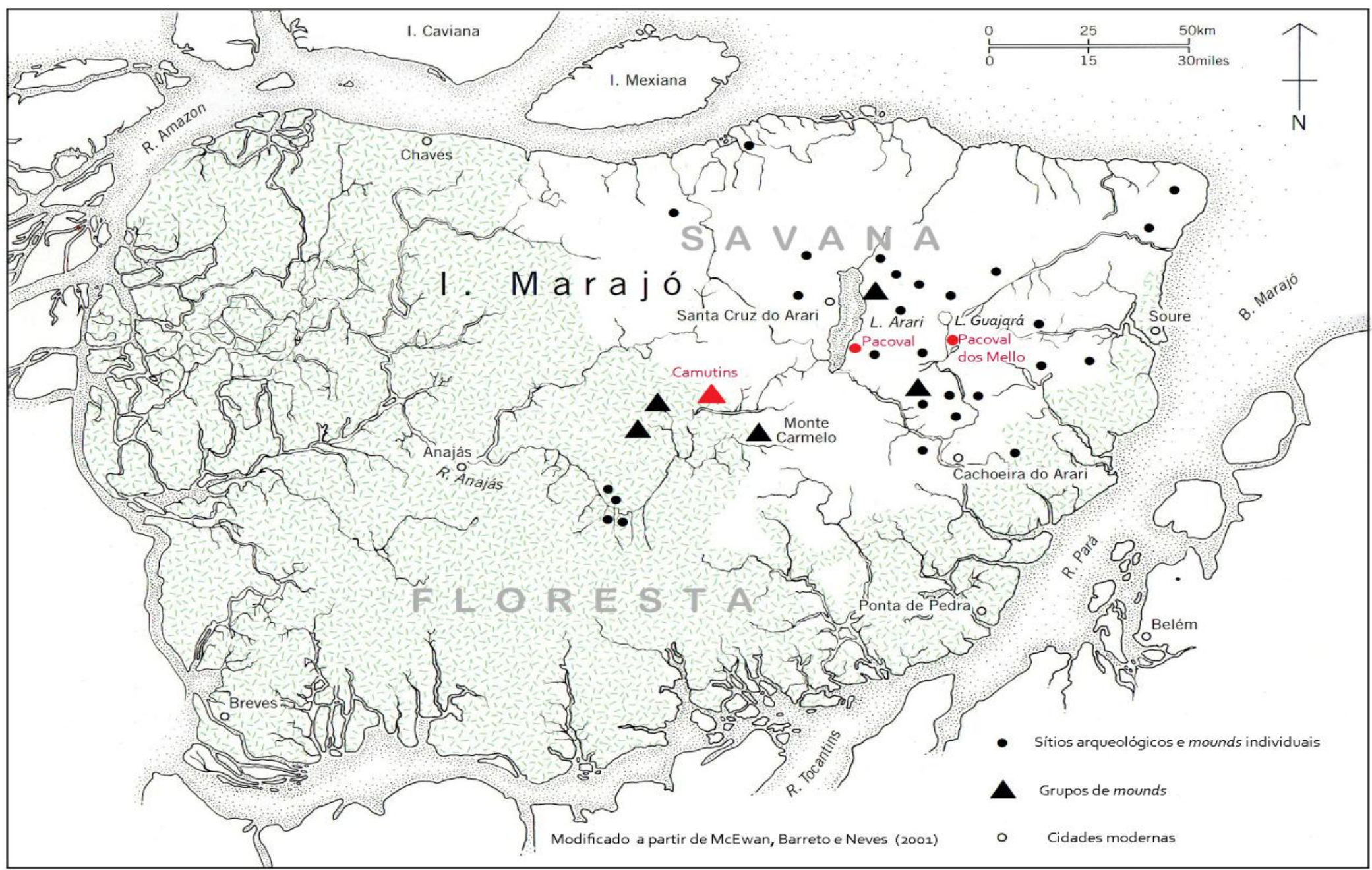

Figura 68. Figura 1- Sítios da fase marajoara. Destacam-se em vermelho os sítios de distribuição das tangas do grupo 1. 


\section{As recorrências estruturais}

Nas 50 tangas deste grupo identificamos certas recorrências estruturais que correspondem a elementos gráficos que constituem um modelo específico de tanga. Tais recorrências são definidas por características estilísticas e iconográficas que se repetem em todas as 50 peças, e com uma gama limitada de variação.

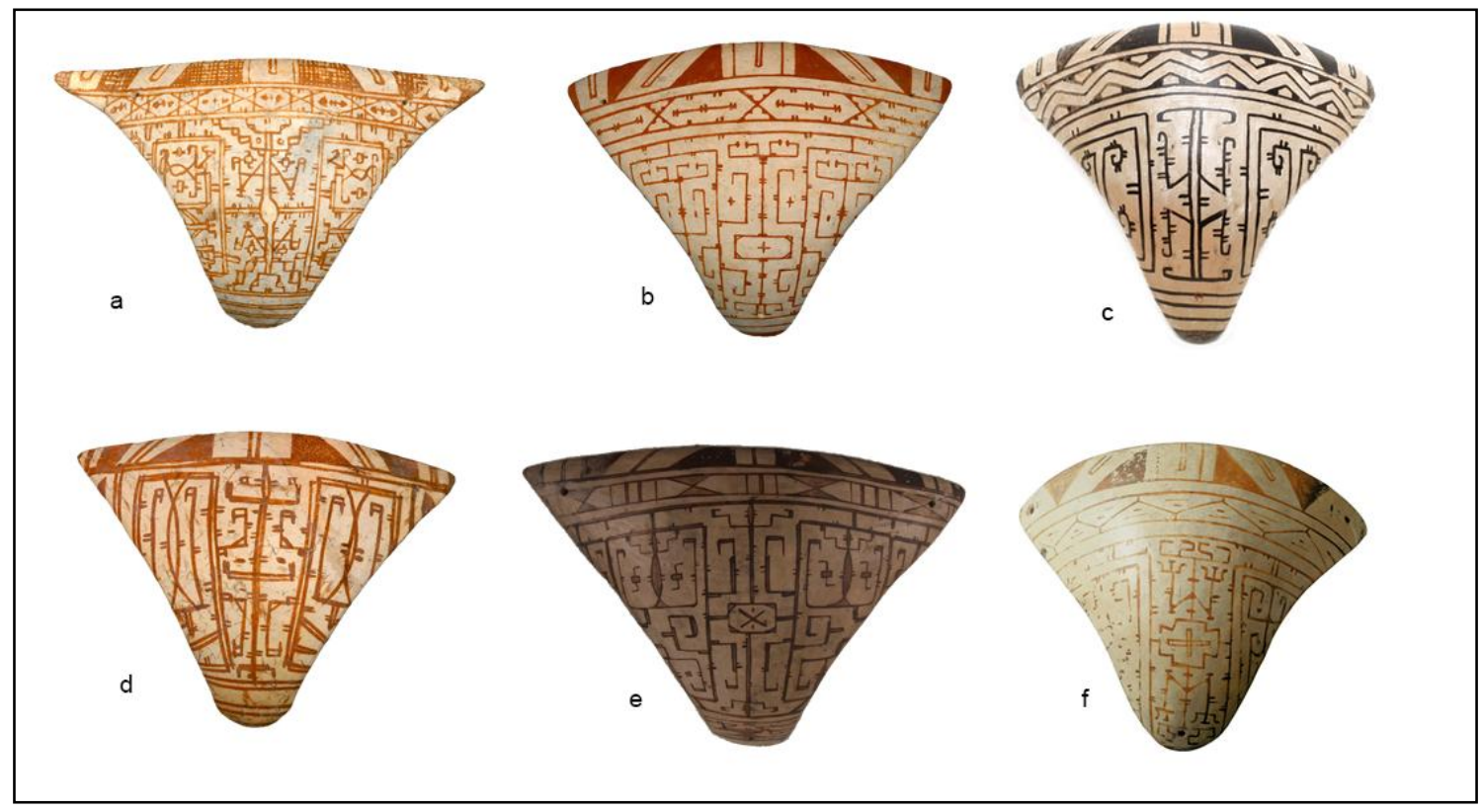

Figura 69- Tangas do grupo 1.

a,b,d. Coleção ICBS/ MAE-USP, Museu e Arqueologia e Etnologia, São Paulo.

c. Museu de Etnográfico de Geneva, Geneva.

e. Museu do Estado de Pernambuco, Recife.

f. Museu Nacional, Rio de Janeiro.

Desta 50 tangas, 45 apresentam a morfologia 1, enquanto a morfologia 2 só ocorreu em quatro. Destas tangas, 44 apresentaram um layout bastante característico, definido por quatro campos gráficos, a dizer, bandas 1 e 2, painel gráfico e linhas. Do total, somente cinco tangas não apresentaram um layout quadripartido, sendo que destas, quatro não possuem a banda 2 e uma possui mais do que quatro campos gráficos.

A banda 1 de todas estas tangas é caracterizada pela presença do padrão 1 , composto por faixas brancas verticais e oblíquas formadas pela justaposição de triângulos ou trapézios, já descrito anteriormente. A variante mais recorrente é aquela cujos trapézios e triângulos são preenchidos por tinta, tendo estado presente 
em 47 tangas. Já a variante cujas figuras são preenchidas por retículas é menos comum, e só esteve presente em 3 tangas, todas de morfologia 2.

A banda 2, por sua vez, apresenta padrões que podem ser divididos no tipo1 e no tipo 2. Os padrões de banda do tipo 1 estão presentes em 22 tangas e aqueles do tipo 2 estão presentes em 23, ou seja, ocorrem quase na mesma frequência.

\section{A composição do painel gráfico}

As imagens exibidas nas tangas deste grupo apresentam um layout bastante distintivo que é caracterizado por dois painéis verticais, um em cada uma das suas laterais, de modo a criar um terceiro painel vertical no centro, conferindo a este campo gráfico três áreas bem delimitadas, conforme pode ser observado na figura 70.
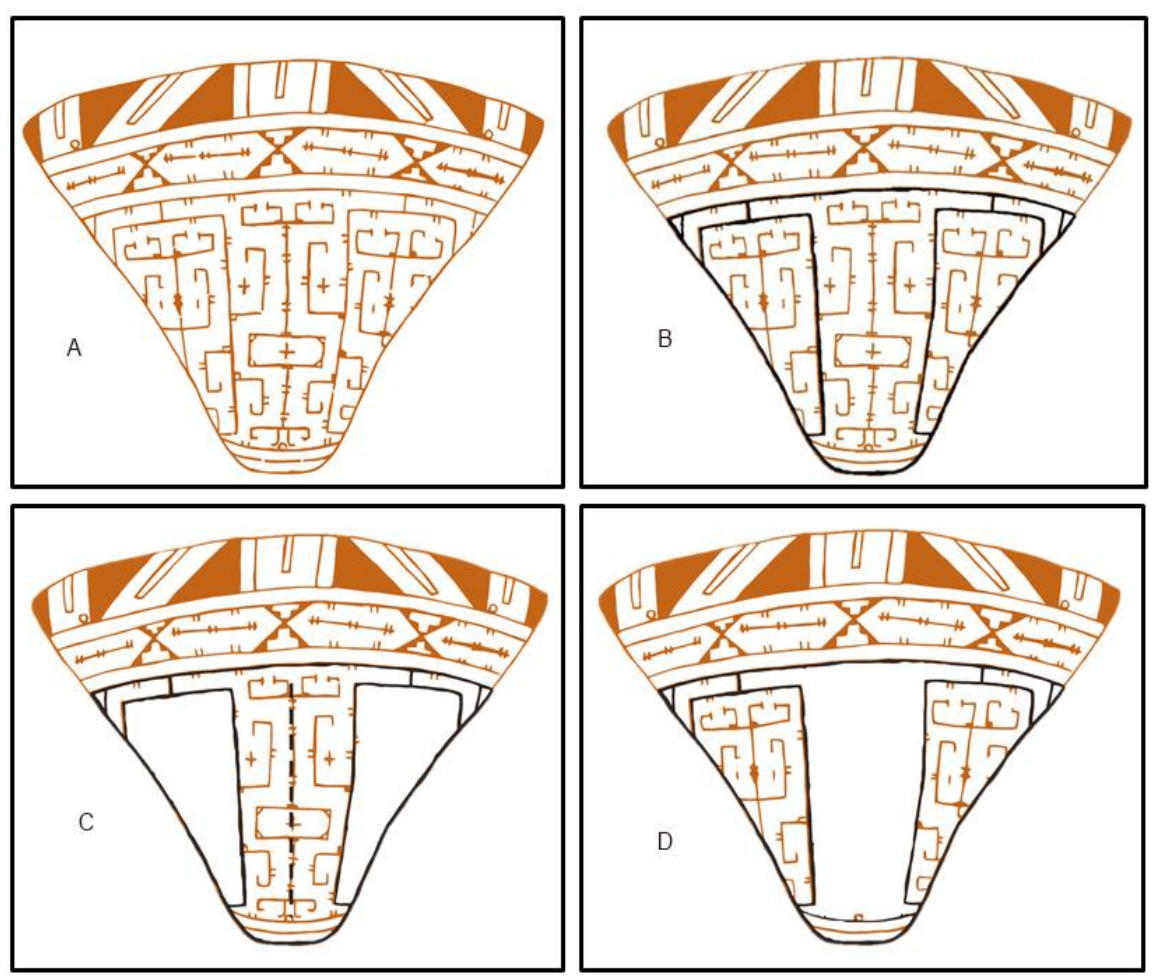

Figura 70- Layout e disposição dos padrões e motivos painel gráfico das tangas do grupo1. A. tanga grupo 1. B. Layout do painel gráfico. C. Motivo "sauro-humano" disposto no painel central. D. Disposição do motivo "pequena face-sauro" nos painéis laterais. Tanga: Coleção ICBS-MAE/USP, Museu de Arqueologia e Etnologia, São Paulo.

Os motivos que ocupam cada um destes três painéis verticais formam um padrão gráfico bastante peculiar que é composto por variantes do motivo sauro- 
humano, no painel vertical central (figura 70c), já descrito anteriormente, e também por variantes do motivo que corresponde a uma pequena face com características felínicas e que é composta por elementos gráficos que aludem a sauros, dispostas sempre nos painéis laterais (figura $70 \mathrm{~d}$ ).

O motivo gráfico que ocupa o painel central e que funciona como um eixo para duplicação simétrica de todo o campo é aquele que alude à figura que chamamos de sauro-humano. Este motivo, apesar de variar, apresenta elementos estruturais recorrentes, como se pode ver na figura 71. Aqui, ele sempre é disposto verticalmente dentro do painel central, ocupando toda a área delimitada, funcionando como um padrão ordenador que coincide não apenas com o eixo de simetria deste campo (ver figura 70.c), mas de toda a tanga.

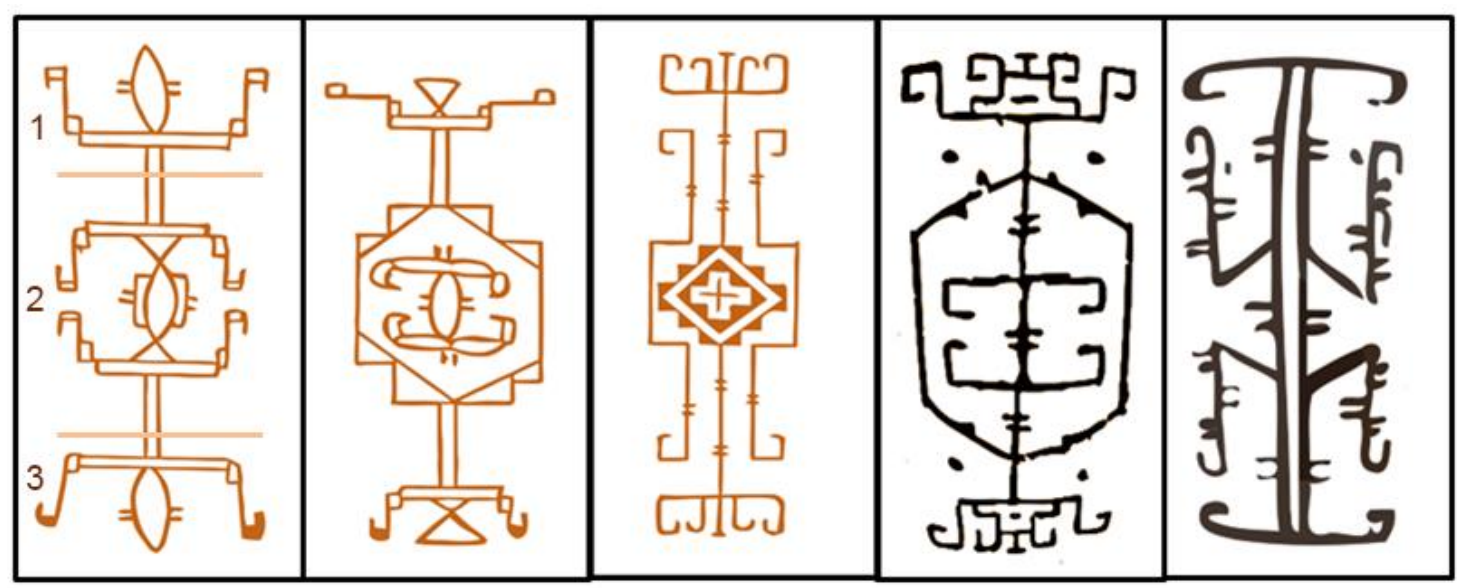

Figura 71. Variantes do padrão $X$, sempre compostas em três eixos, que sempre são graficamente dispostas no painel central.

Conforme destacado anteriormente, esta figura é simetricamente duplicada, mostrada de corpo inteiro, como se vista por cima, e o seu tronco é sugerido por figuras quadrangulares ou losangulares. Especificamente, neste grupo, os seus membros podem ser destacados a partir de um tronco losangular, mas também podem ser sugeridos a partir de suas extremidades, de onde por vezes a cabeça também é sugerida.

A duplicação simétrica desta figura se dá sempre a partir de um eixo central, que neste caso específico, alude ao seu dorso. Deste modo, a figura é sempre composta por três eixos bem visíveis, a dizer: um eixo central (dorso) e duas extremidades (cabeças ou membros). Deste modo, assim como o padrão do painel 
gráfico, este motivo apresenta uma composição tripartida, como se vê na figura abaixo.

O outro motivo que também compõe a imagem é aquele que mostra uma pequena face que parece aludir a um ser felínico e que ocupa os dois painéis laterais. Embora possua variantes, todas apresentam características estruturais comuns, como por exemplo, um eixo central que sugere um nariz ou focinho e também uma boca, que é composto por uma figura de sauro, na maioria das vezes simplificada. Ladeando este elemento gráfico central, elementos quadrangulares ou pontos aludem aos olhos (figura 72).
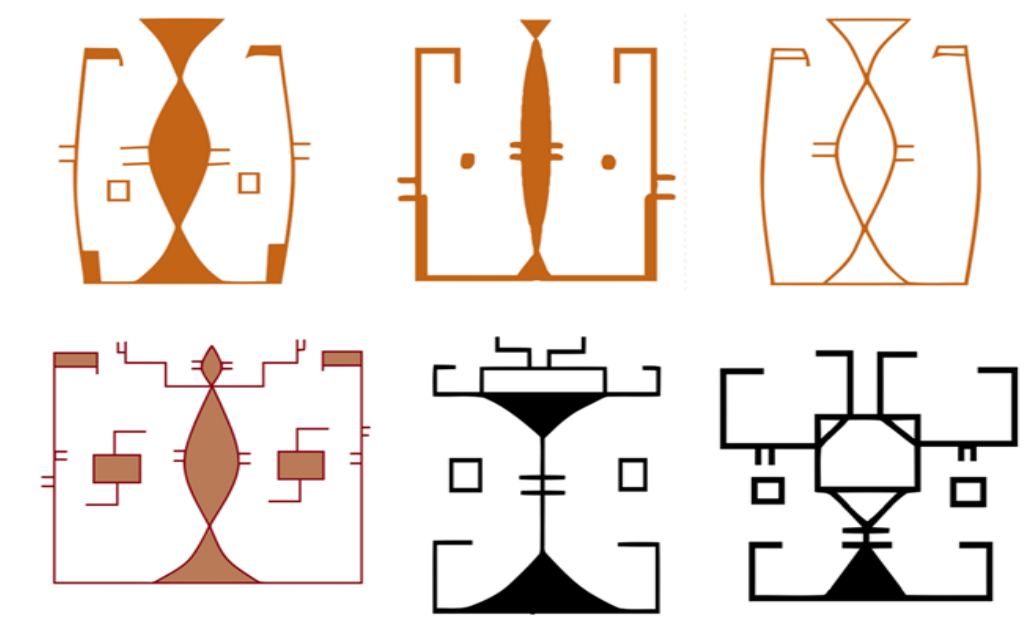

Figura 72. Algumas variantes do motivo que alude a uma pequena face e, que, no grupo 1 , aparece localizado sempre nos painéis laterais.

Os dois motivos gráficos acima mencionados, quando dispostos sobre 0 painel gráfico, criam um padrão gráfico bem distinto. Com base no rigoroso princípio de espelhamento, que nas tangas deste grupo é paradigmático, reconstituímos em um rollout o padrão do painel gráfico com o intuito de melhor detalhar os princípios subjacentes à imagem vista neste campo gráfico. Isto permitiu perceber dois princípios implícitos, mas fundamentais tanto para a compreensão de como o padrão recortado que é mostrado no painel gráfico pode ser reconstituído virtualmente, quanto para a formação do tipo específico de imagem visto neste grupo de tangas: o desdobramento a partir de dois eixos perpendiculares e o recorte de parte da figura desdobrada (figura 73).

Conforme mencionado anteriormente, nas tangas, a simetria bilateral ou reflexiva é o tipo mais comum de simetria usado para estruturar as imagens do 
painel gráfico. Entre as 50 tangas deste grupo todo o padrão gráfico pode ser desdobrado a partir de dois eixos de simetria perpendiculares, um deles virtual, resultando em um padrão formado a partir da união de duas faces distintas, mas unidas por um elemento quadrangular em seu centro, que neste caso, alude ao nariz da figura de face (figura 73c).

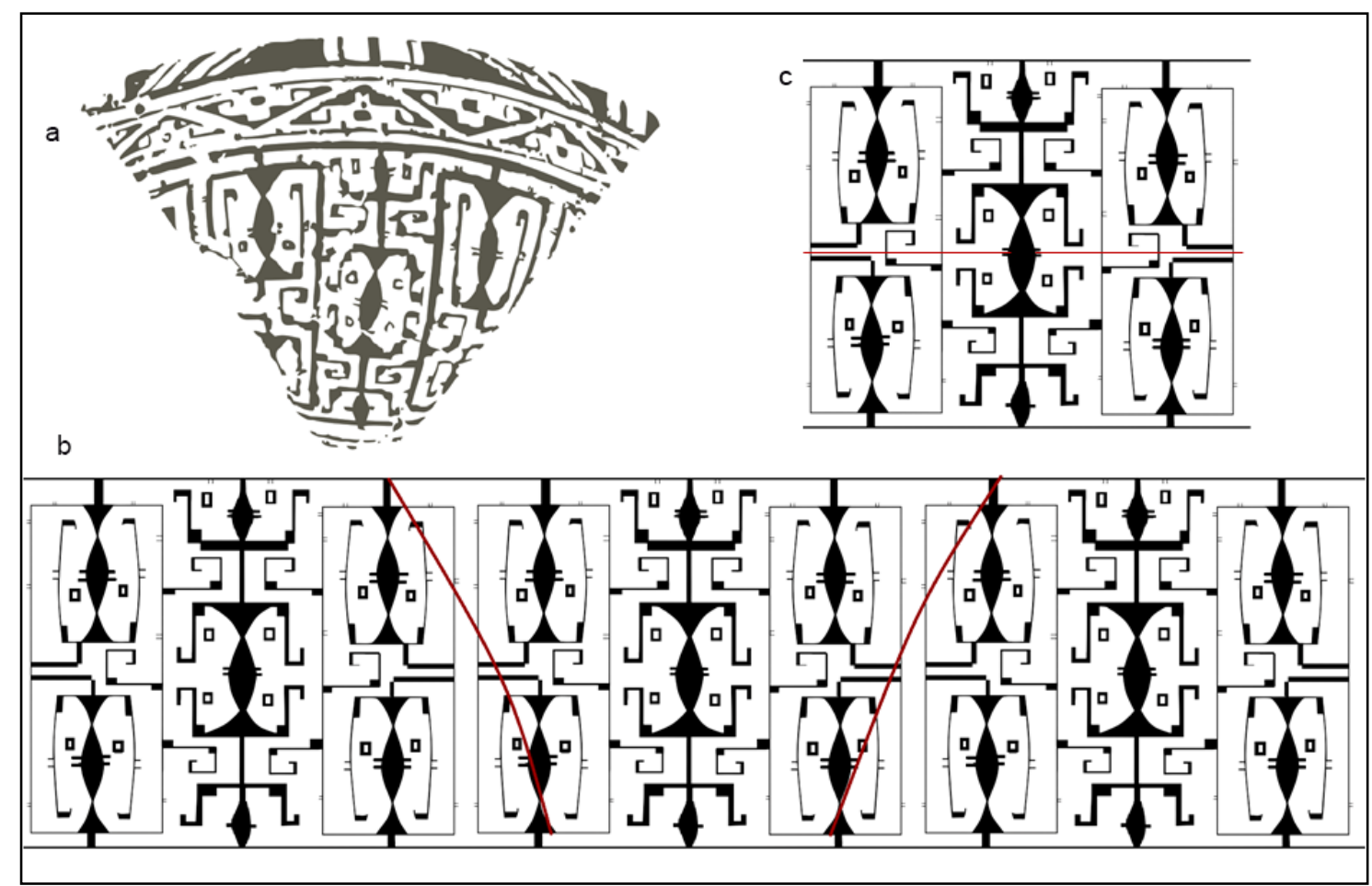

Figura 73- Rollout hipotético do padrão do painel gráfico.

a- Tanga do grupo 1. Desenhado a partir de Meggers e Evans, 1957.

b- Reconstituição do padrão allover sugerido com o recorte do padrão do painel gráfico. As linhas vermelhas destacam o recorte da imagem na tanga.

c- Rollout do padrão gráfico. A linha vermelha indica o eixo horizontal a partir de onde a figura é desdobrada.

O desdobramento cria um padrão com duas faces opostas, cada uma delas caracterizada por um par de olhos e por um cenho, mas compartilham o mesmo nariz, que normalmente corresponde ao dorso da figura que alude ao sauro-humano. É importante frisar que o padrão do painel gráfico da tanga exibe apenas uma destas faces, a outra é apenas sugerida, por meio do recorte. Ao recortar parte da imagem duplicada, neste caso específico, as cabeças laterais inferiores, aquilo que era antes o cenho da face espelhada na parte inferior se torna uma boca.

Ao passo que a imagem exibida em boa parte das 50 tangas deste grupo é estruturada a partir de um eixo de simetria vertical e outro eixo simétrico horizontal, um visível e o outro virtual, em 13 tangas as imagens vistas são desdobradas 
apenas em um eixo simétrico, divididas em duas metades, uma direita e outra esquerda, conforme é possível observar na figura $74 \mathrm{~d}$.

Esta característica é bem marcada, sobretudo, em um conjunto de cinco tangas que compartilham da mesma variante do padrão. Como se pode observar no rollout do padrão de uma delas, a imagem não é estruturada a partir de duas faces desdobradas, como ocorre nas tangas descritas acima. Nota-se, neste caso específico, que a imagem é dividida em duas metades a partir de um eixo de simetria vertical. Em decorrência disto, a imagem surgida da combinação dos motivos que aludem à figura do sauro-humano e a figuras de pequenas faces, mostra uma única figura de face, com olhos, cenho, nariz e boca.

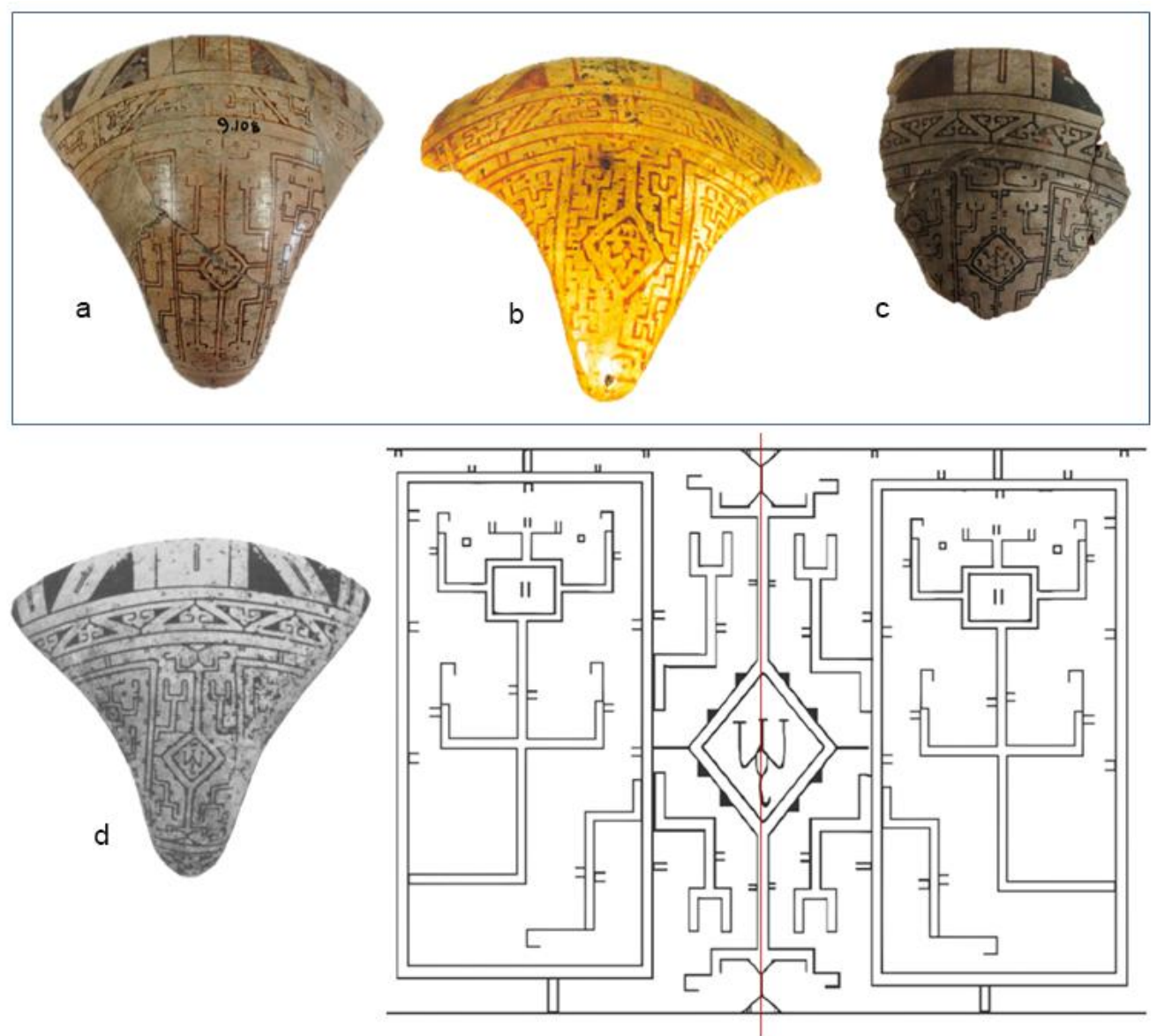

Figura 74. Imagem do painel gráfico estruturada a partir de um eixo de simetria vertical.

a: Museu Nacional, Rio de Janeiro.

b: Coleção Montenegro, Museu do Instituto Histórico e Geográfico de Alagoas, Maceió.

c: Museu Nacional, Rio de Janeiro.

d. Rollout da imagem do painel gráfico da tanga. National Museum of American Indian, Nova York. Fonte: Palmatary, 1950: 353. 
É importante observar que independentemente da forma como as figuras são desdobradas, as imagens resultantes são recortadas ao modo da técnica de "janela ao infinito", já comentada neste capítulo. No entanto, o enquadramento destas imagens, por meio do seu recorte, atenta também às transformações ocorridas dentro do próprio campo gráfico.

Conforme já comentamos na primeira parte deste capítulo, o encaixe múltiplo de imagens é uma característica comum das tangas, mas especificamente entre as tangas deste grupo, esta é uma característica paradigmática. Aqui, é exibida uma face que revela outras imagens dentro de si. Assim, a imagem ora mostra uma face com olhos, cenho, nariz e boca, ora mostra figuras em seu interior, como por exemplo, faces menores que se abrem e mostram um ser sauromorfo em seu interior. Além disto, outras figuras podem ser vistas dentro da imagem dependendo de onde o olhar se foca, como por exemplo, corpos e seres antropomorfos, como se pode perceber na figura 75 . Ou seja, as imagens vistas aqui são múltiplas e podem se transformar constantemente.
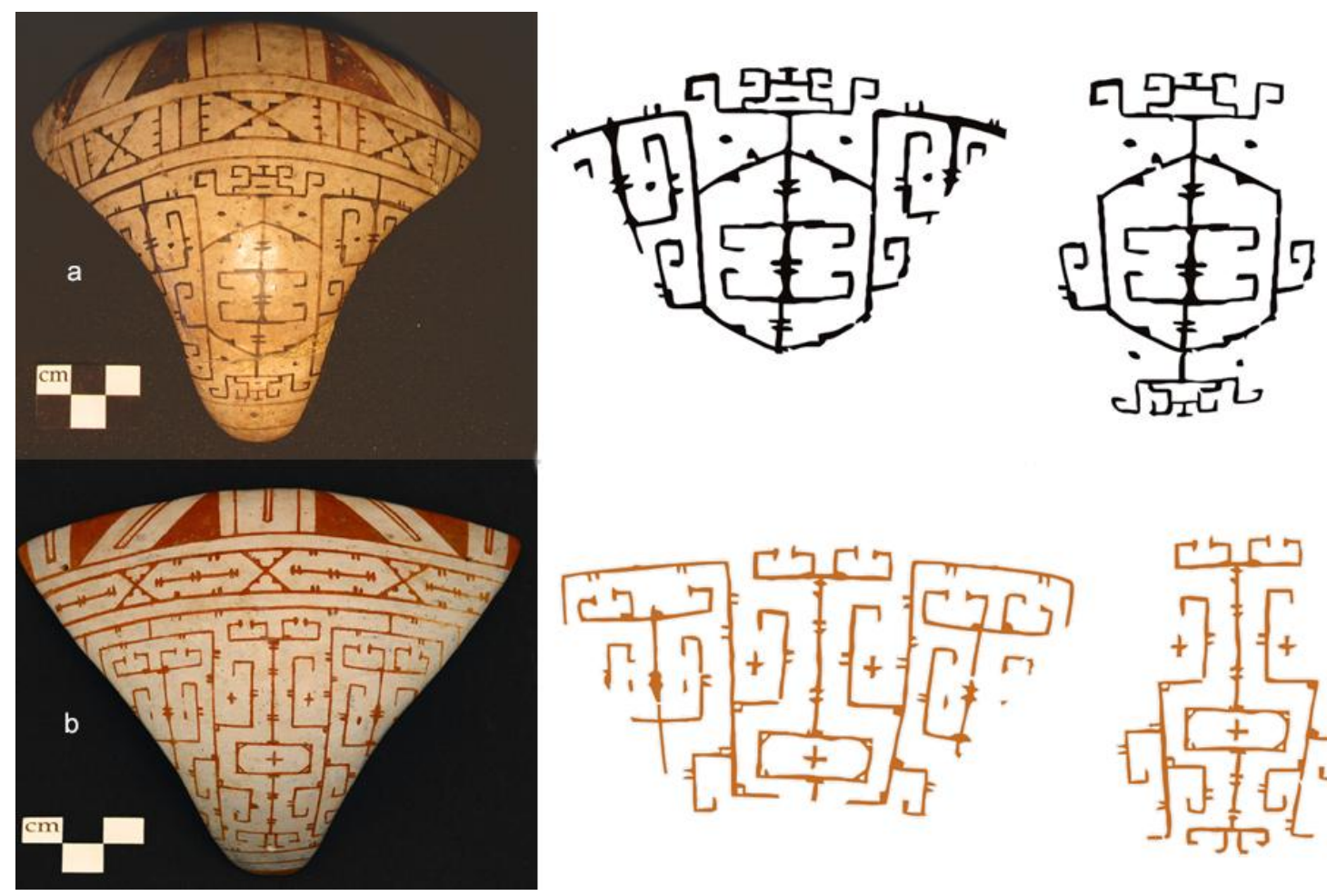

Figura 75. Imagens caracterizadas pelo encaixe múltiplo de figuras.

a.Museu Paraense Emílio Goeldi, Belém.

b. Coleção ICBS-MAE/USP, Museu de Arqueologia e Etnologia, São Paulo 


\subsection{As tangas do Grupo 2}

Este grupo abrange 29 tangas com características bem homogêneas quanto ao seu layout e motivos gráficos. Prous e Lima (2011) observaram que estas tangas apresentam características bastante homogêneas quanto ao seu layout que podem assim ser resumidas: os grafismos são elaborados por uma tinta bastante espessa; layout caracterizado por três campos gráficos; a banda 1 é mais larga do que em outras tangas e sempre ocupada pelo padrão do tipo 1; a banda 2 é muito larga, ocupando a parte central da tanga e em função disto o painel gráfico é sempre mais reduzido, ocupando a porção inferior da tanga; a morfologia 3 só ocorre com estas tangas, mas aqui também pode ocorrer com a morfologia 1, mas esta é mais arredondada quando ocorre com estas tangas.

As tangas analisadas deste grupo estão distribuídas em quatro coleções depositadas em dois museus diferentes.

\begin{tabular}{|c|c|c|}
\hline \multicolumn{3}{|c|}{ Tangas do grupo 2} \\
\hline Coleção/ Instituição & Quantidade & Procedência \\
\hline ICBS-MAE & 06 & $\begin{array}{c}\text { Rio Camutins, Fazenda São } \\
\text { Marcos }\end{array}$ \\
\hline 006 MAE-USP & 02 & Os Camutins, teso Furinho \\
\hline $\begin{array}{l}\text { Governo do Estado do } \\
\text { Pará/ MPEG }\end{array}$ & 8 & $\begin{array}{l}\text { Rio Camutins, Fazenda São } \\
\text { Marcos }\end{array}$ \\
\hline $\begin{array}{c}\text { Museu Paraense Emílio } \\
\text { Goeldi }\end{array}$ & 1 & Os Camutins, Teso Belém \\
\hline
\end{tabular}

Também incorporamos tangas das instituições relacionadas na tababela abaixo.

\begin{tabular}{|c|c|}
\hline Coleção/ Instituição & Quantidade \\
\hline Museu do Marajó & 5 \\
\hline $\begin{array}{c}\text { Museu Nacional de Etnologia } \\
\text { de Lisboa }\end{array}$ & 1 \\
\hline Denver Art Museum & 5 \\
\hline $\begin{array}{c}\text { Antiga coleção Jean Eugéne } \\
\text { Lyons, Geneva (coleção } \\
\text { particular) }\end{array}$ & 1 \\
\hline
\end{tabular}


A maior parte das tangas deste grupo possui a sua policromia parcialmente prejudicada ou perdida integralmente. Quase todas estas tangas tiveram os seus grafismos elaborado com tinta vermelha, entretanto, quando esta tinta não foi integralmente perdida, na maioria das vezes, apresenta desbotamento. No entanto, em muitos casos foi possível observar a presença das linhas estruturais.

Incorporamos neste grupo algumas tangas que não apresentam, necessariamente, o layout tripartido ou um espaço muito grande entre os campos gráficos. No entanto, estas peças apresentam o mesmo tipo de composição na banda 2, além de painel gráfico estruturado pelos mesmos princípios e motivos , como é possível observar, por exemplo, na figura 76b e figura 77c.

Há duas formas de estruturar o painel gráfico destas tangas. Na primeira, que é a mais comum (figura 76), este campo é dividido, na maioria das vezes, em três painéis que são sempre ocupados por figuras aludindo ao sauro, seres serpentelíneos, pequenas figuras aludindo a faces, por um elemento em forma de linhas duplas reticuladas, e algumas vezes, elementos em forma de volutas e ganchos.

Este modo de estruturar o painel é bastante semelhante ao que é visto nas tangas do grupo 1, inclusive, pela recorrência de motivos aludindo à figura do saurohumano e pequenas faces, no entanto, devido à perda da policromia de boa parte das tangas, não pudemos avaliar se, assim como naquele grupo, estes motivos ocorrem associados. Além disto, o padrão nunca é desdobrado a partir de dois eixos perpendiculares, como pode ocorrer nas tangas do grupo 1, aqui o desdobramento é sempre realizado horizontalmente.

É importante destacar que não é frequente que a imagem composta neste campo aluda a uma face, no entanto, em alguns casos, sobretudo, quando o painel central é ocupado pelo motivo em forma de linhas duplas reticuladas, uma face é sugerida, mas com poucas das características que são comuns nas faces marajoara, como pode ser visto na figura 76a e 76d. Nestes casos específicos, só os olhos são sugeridos, ora por motivos que aludem ao sauro (figura $76 \mathrm{c}$ ), ora por motivos aludindo pequenas faces (figura $76 \mathrm{~d}$ ). 

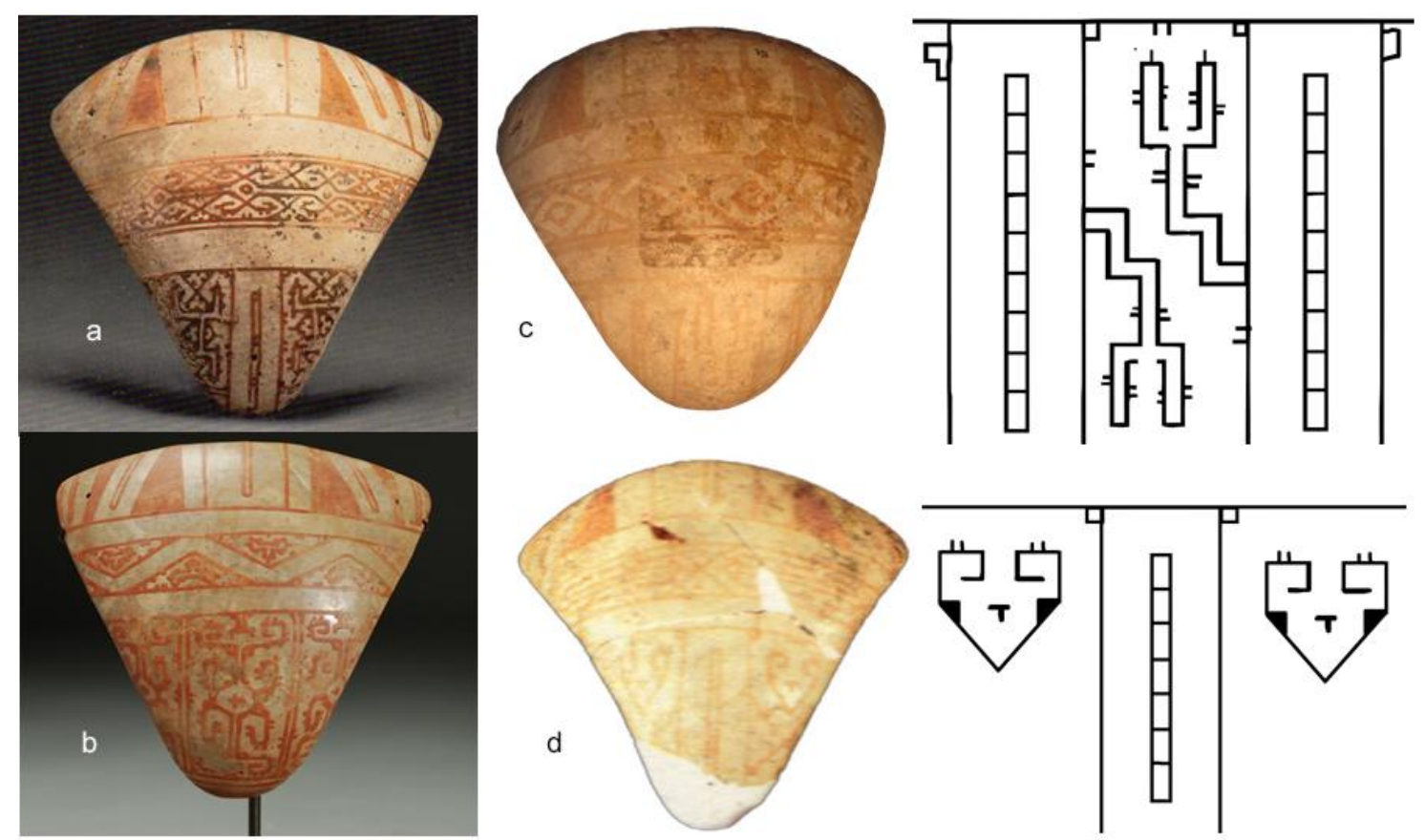

Figura 76. Tangas com painel gráfico estruturado em painéis.

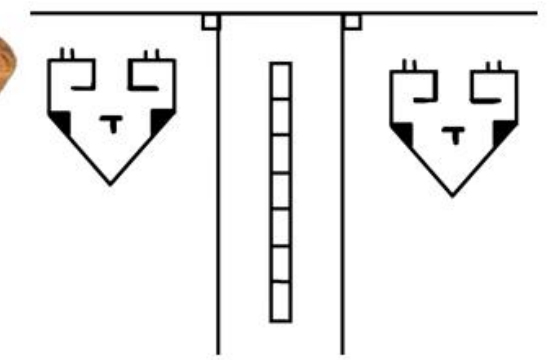

a. Painéis laterais com motivos aludindo a sauros.

Denver Art Museum, Denver. Fonte: Young-Sánchez e Schaan, 2011.

b. Painéis com motivos que aludem a sauros. Nota-se que as linhas horizontais abaixo do painel gráfico. Antiga coleção Jean Eugéne Lyon.

c. Painéis laterais com motivos em forma de linhas duplas reticuladas e painel central com motivo aludindo a sauro estilizado. Acervo do Governo do Estado do Pará, Museu Paraense Emílio Goeldi.

d. Painéis laterais com motivos que aludem a pequenas faces e painel central com motivo em forma de linhas duplas reticuladas. Museu do Marajó, Cachoeira do Arari. Fonte: Schaan, 2009: 374.

Já a segunda variante possui o seu painel gráfico estruturado em vários espaços semelhantes e de formato hexagonal, alternados por meio da reflexão deslizante (figura 77) e, após isto, preenchidos, por uma variante do motivo "cruz no medalhão" no espaço central e os outros espaços preenchidos pelo motivo que alude a uma pequena face (Figuras 77a e 77b) ou pode ser apenas preenchido por motivos que se assemelham ao motivo "cruz no medalhão", como ocorre na tanga da figura $77 \mathrm{~b}$.

Estas tangas podem, às vezes, aludir a uma figura de face, como é visto por exemplo na figura $77 \mathrm{a}$, onde os motivos de pequenas faces sugerem os olhos e 0 motivo cruz no medalhão sugere o nariz e a boca. No entanto, outras vezes, várias faces podem ser sugeridas, de acordo com o deslocamento do olhar, como é o caso da figura $77 \mathrm{~b}$, onde várias faces com grandes olhos e nariz/boca podem ser vistas, de acordo com onde se olha. 


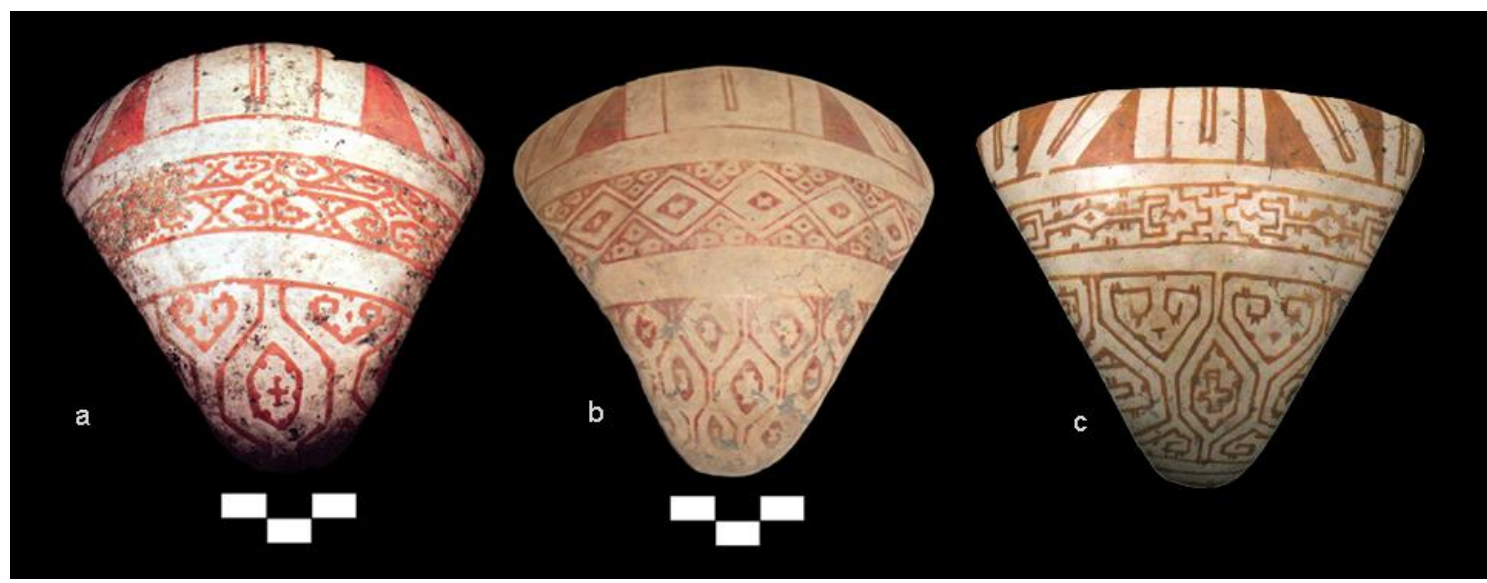

Figura 77. Tangas com painéis gráficos estruturados em espaços hexagonais alternados por meio da reflexão deslizante.

a. Museu do Marajó, Cachoeira do Arari. Fonte: Schaan, 2009: 375.

b. Museu de Arqueologia e Etnologia, São Paulo.

c. Antiga coleção Jean Eugéne Lyon. Fonte: robertmorrisfineart.com

Os padrões da banda 2 destas tangas, embora apresentem semelhanças com aqueles já descritos, são elaborações bastante originais. Em algumas são elaborados por elementos triangulares replicados por meio da reflexão deslizante criando uma faixa em ziguezague, como na figura $76 \mathrm{~b}$, por exemplo, ao modo visto nas tangas dos outros grupos. No entanto, a grande maioria deles é elaborada com figuras bastante complexas, que ora, podem aludir a sauros, ora podem aludir a diversas faces.

O padrão ilustrado na figura 78 , por exemplo, é composto por meio da reflexão e desdobramento de um único motivo que alude a uma pequena face com olhos nariz e cenho. O desdobramento deste motivo em um eixo vertical transforma este motivo em uma figura que alude a um sauro. Do mesmo modo, do espelhamento deste sauro surge outra figura de sauro. Além disto, estas figuras de sauro podem se transformar, dependendo de onde o olhar é enquadrado, e revelar figuras de faces, algumas, inclusive, aludindo a uma face felínica (figura 78f). Percebe-se, assim, que enquanto as imagens vistas nos painéis gráficos destas tangas não apresentam elaborações para engajar o olhar, as imagens vistas nas bandas, pelo contrário, estimulam o olhar a perceber diversas transformações de um ser em outro. Isto explicaria a razão pela qual em 17 das 29 tangas deste grupo a banda 2 ocupa o seu centro, enquanto que o painel gráfico é mais estreito. 


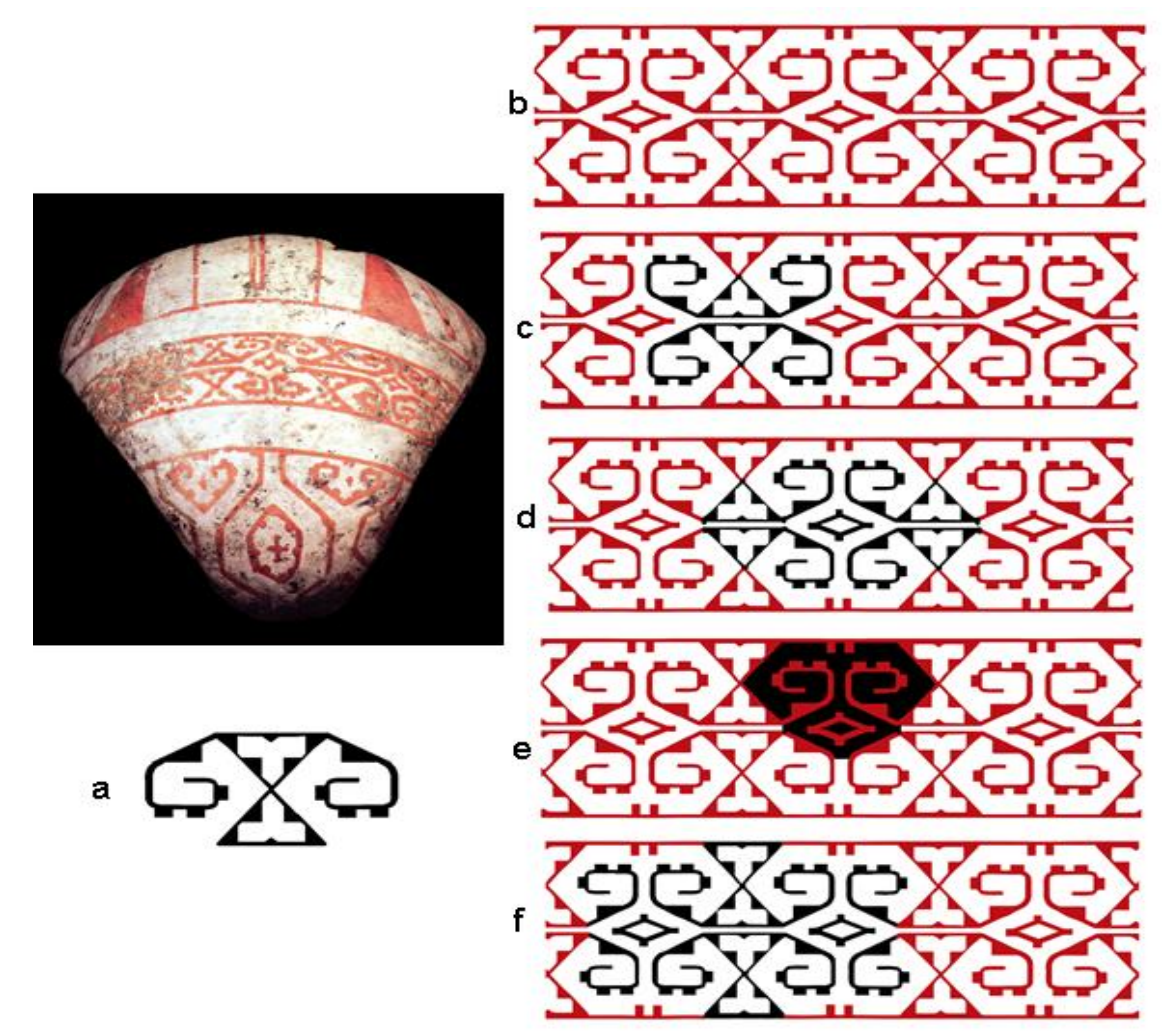

Figura 78. Padrão da banda 2 aludindo a várias transformações. Tanga do acervo do Museu do Marajó. Fonte: Schaan, 2009: 375)

a. Motivo replicado na elaboração do padrão.

b. Padrão resultante da reflexão e do desdobramento do motivo anterior.

c. Figura que alude a um sauro elaborada pelo desdobramento do motivo.

d. Figura aludindo a sauro bicéfalo formada na junção entre outras figuras de sauro.

e. Figura de face formada entre o dorso e os membros do sauro da junção.

f. Possível figura de face felínica composta pelo sauro do desdobramento e pelo sauro da junção.

\subsection{As tangas do grupo 3}

Este grupo é integrado por 10 tangas, todas caracterizadas pela presença de um painel dividido em duas metades por um eixo de simetria vertical muito bem marcado. Além disto, estas tangas apresentam uma consistência em relação ao tema iconográfico figurado, apresentando figuras que aludem ao peixeserpentelíneo, bem quanto aos efeitos perceptivos relacionados ao agenciamento do olhar.

A maior parte das tangas analisadas deste grupo é do acervo do Museu Nacional, como pode ser visto na tabela abaixo. 


\begin{tabular}{|c|c|c|}
\hline \multicolumn{2}{|c|}{ Tangas grupo 3 } \\
\hline Coleção / Instituição & Quantidade & Procedência \\
\hline Museu Nacional & 4 & Indeterminada \\
\hline $\begin{array}{c}\text { Coleção Graciete, } \\
\text { ICBS/MAE/USP }\end{array}$ & 1 & Tesos do Os Camutins \\
\hline $\begin{array}{c}\text { Museu Paraense Emílio } \\
\text { Goeldi }\end{array}$ & 1 & Pacoval \\
\hline
\end{tabular}

Além disto, incorporamos na análise quatro tangas, uma Coleção Governo do Estado do Pará, em Belém, uma da antiga Coleção Barbier Mueller, em Geneva, uma do American Museum of Natural History, em Nova York, além de uma tanga de uma coleção não identificada.

Destas 10 tangas, oito são estruturadas em três campos gráficos, banda 1, banda 2 e painel gráfico, ou seja, não apresentam as linhas na extremidade inferior (figura 79a, 79b, 79c). Todas estas apresentam a banda 1 composta pelo padrão gráfico do tipo a, ou seja, composta por faixas oblíquas brancas intercaladas por triângulos ou trapézios pintados, e apresentam também o padrão da banda 2 composto por variantes do padrão 2 , ou seja, aquela que apresenta uma faixa em ziguezague criada por meio replicação de triângulos por reflexão deslizante. Destas, com exceção de uma, todas são de morfologia 1.

As outras duas são compostas apenas pelo painel gráfico e banda 1, sendo que uma possui o padrão da banda 1 do tipo 2, e a outra não foi possível identificar o tipo devido a perda de policromia. As duas são de morfologia 2 (figura 79c, 79e). 

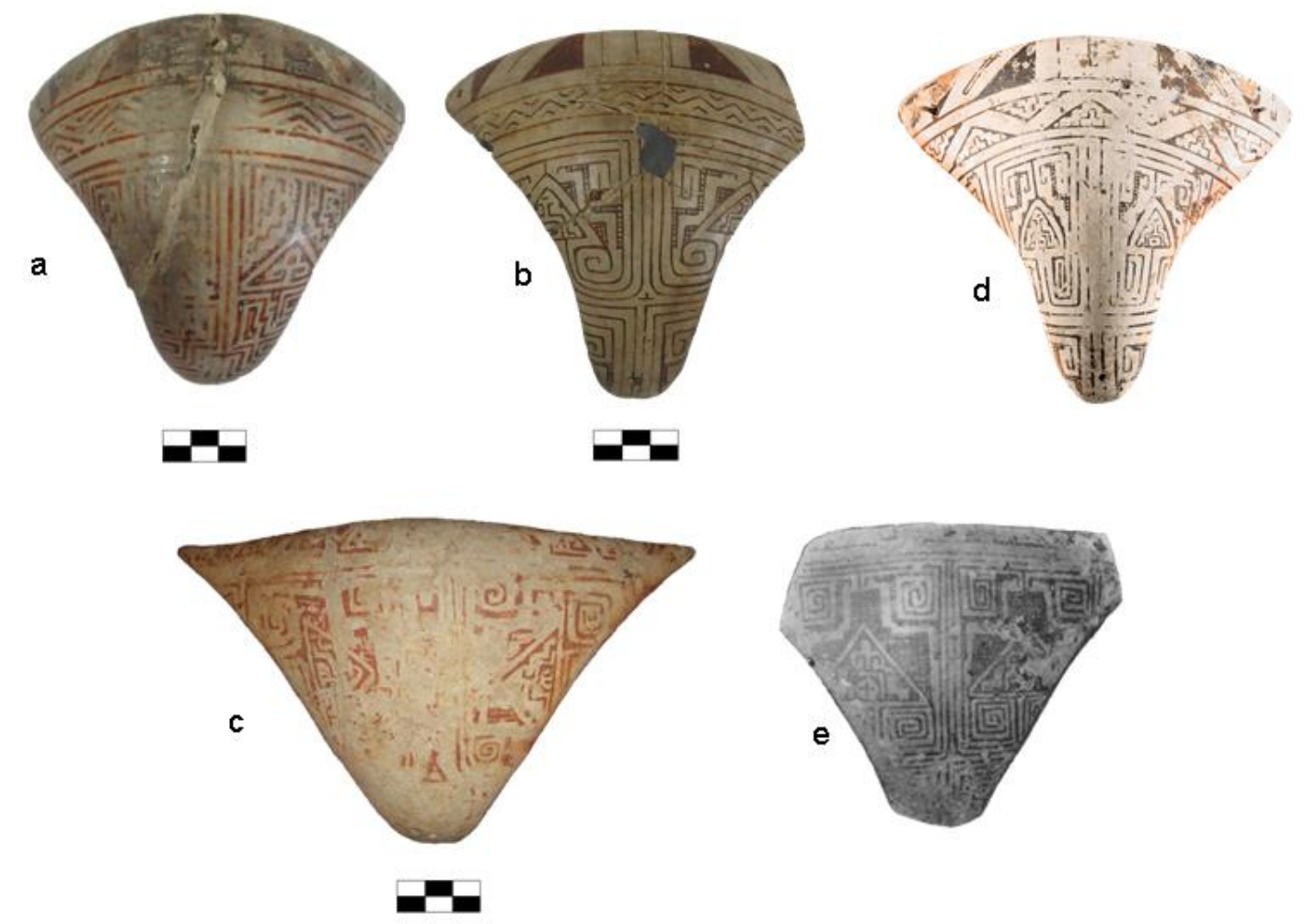

Figura 79. Tangas cujas imagens do painel gráfico são estruturadas por meio do desdobramento a partir de um eixo horizontal da figura que alude ao peixe-serpentelíneo. Percebe-se que em todas as tangas a figura deste ser esta posicionada verticalmente, com exceção daquela ilustrada na figura $\mathrm{C}$, cuja cabeça está voltada para o eixo do painel.
a, b. Museu Nacional, Rio de Janeiro.
c. Coleção ICBS/ MAE-USP, Museu de Arqueologia e Etnologia, São Paulo.
d. Antiga coleção Barbier Mueller, Geneva. Fonte: Sothesby.com
e. American Museum of Natural History, Nova York. Fonte Palmatary, 1950: 461.

O padrão do painel gráfico destas tangas mostra uma face composta pelo desdobramento, em um eixo horizontal, de motivos aludindo à figura do peixeserpentelíneo como visto na abaixo (figura 80). Por meio deste desdobramento, as cabeças daquele ser se transformam nos olhos, enquanto outros elementos vistos em seu corpo se transformam em narinas e na boca. É importante destacar que o desdobramento desta figura em um plano virtual cria uma nova figura de face na junção entre os motivos desdobrados, como pode ser visto na figura $80 \mathrm{e}$. 

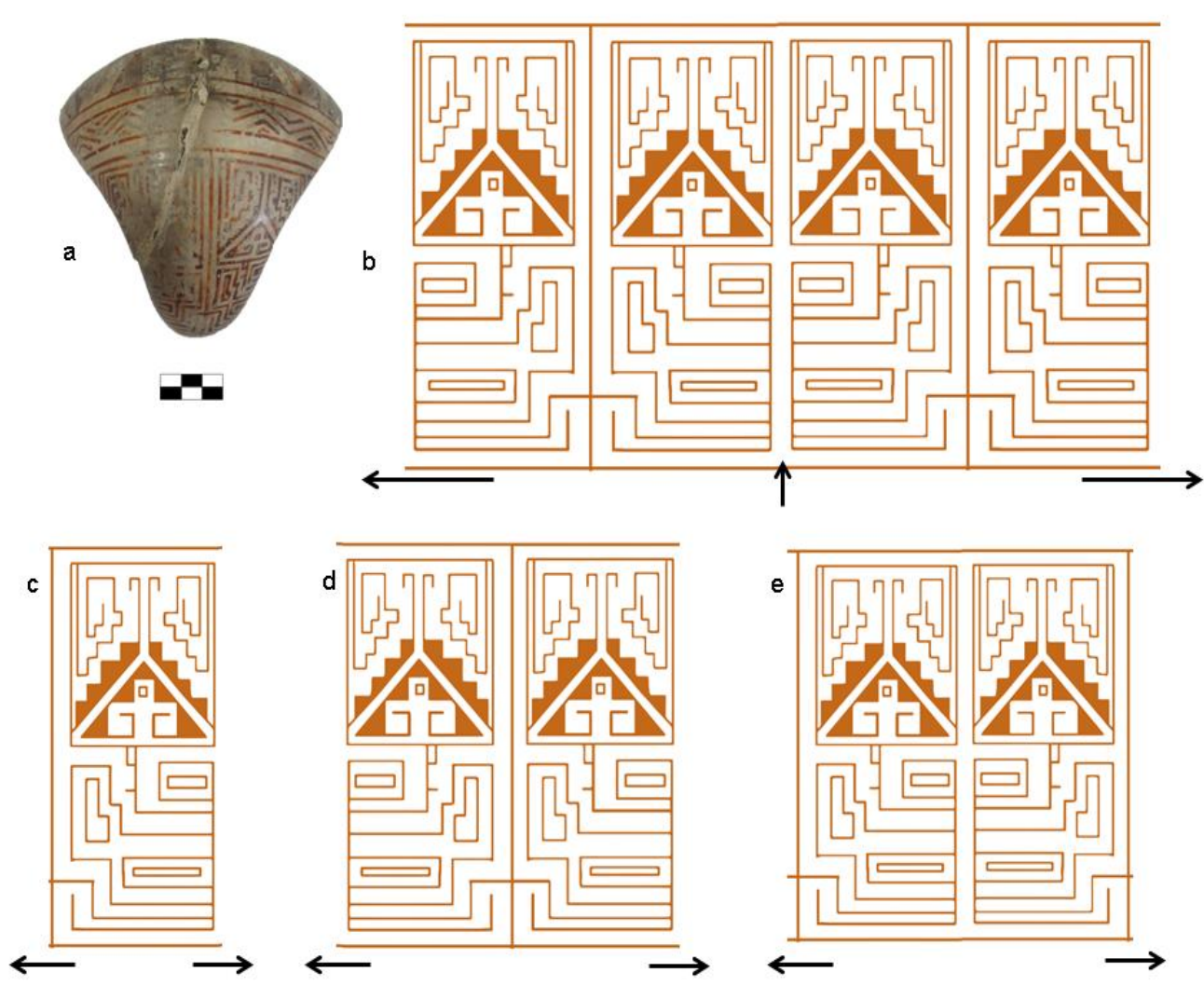

Figura 80. Composição de imagem que alude a uma face por meio do desdobramento do motivo do peixe-serpentelíneo.

a. Tanga com imagem de face no painel gráfico composta pelo desdobramento do motivo. Museu Nacional, Rio de Janeiro.

b. Rollout do padrão visto na tanga com seu desdobramento em um plano virtual. Destaque para o ponto de junção entre os motivos refletidos, onde uma nova figura é formada.

c. Motivo dobrado.

d. Padrão formado pelo desdobramento do motivo aludindo a uma face.

e. Nova figura de face formada no ponto de junção entre os motivos refletidos.

Como se observa, a maior elaboração gráfica destas tangas é a transformação da figura aludindo ao peixe-serpentelíneo, em uma face por meio do seu desdobramento, o que agencia o olhar a um plano virtual onde estas figuras continuam se transformando e criando novas imagens. Isto é bem diferente, por exemplo, do que ocorre com as tangas do grupo 1, onde o painel gráfico é repleto de figuras que se abrem revelando outras, mantendo a atenção na própria imagem e nas várias figuras vistas ao mesmo tempo. Aqui, ao contrário, para a percepção de outras imagens se requer o uso da "imaginação perceptiva" que conduz o olhar para fora do campo da imagem "física". 


\subsection{As tangas do Grupo 4}

Este grupo abrange 19 tangas cujos painéis gráficos são semelhantemente estruturados, mas elaborados por motivos diversos, que ora aludem a partes do peixe-serpentelíneo, ora aludem a partes do sauro, mas em todas formam uma figura que alude a uma face.

As tangas analisadas deste grupo estão distribuídas pelas seguintes instituições:

\begin{tabular}{|c|c|c|}
\hline \multicolumn{2}{|c|}{ Tangas grupo 4 } \\
\hline Coleção/ Instituição & Quantidade & Procedência \\
\hline ICBS/ MAE-USP & 4 & $\begin{array}{c}\text { Fazenda São Marcos, tesos } \\
\text { Camutins e Urubu }\end{array}$ \\
\hline $\begin{array}{c}\text { Museu Nacional } \\
\text { Museu Paraense Emílio } \\
\text { Goeldi }\end{array}$ & 5 & Tndeterminada \\
\hline $\begin{array}{c}\text { Museu do Estado de } \\
\text { Pernambuco }\end{array}$ & 2 & Teso Severino (1 tanga) \\
\hline
\end{tabular}

Também incorporamos quatro tangas, uma da Coleção Governo do Estado do Pará, uma do Museu do Marajó, em Cachoeira do Arari, uma do Peabody Museum de Havard e uma da antiga Coleção Instituto Cultural Banco santos.

Destas tangas, onze são de morfologia 1 e sete são de morfologia 2. A maior parte delas é estruturada com banda 1, banda 2, painel gráfico e linhas. Sendo o padrão de banda do tipo $1 \mathrm{a}$, ou seja, aquela caracterizado por faixas claras alternadas com triângulos ou trapézios preenchidos por tinta, o que mais ocorre na banda 1. Já na banda 2 o padrão mais frequente é aquele composto por elementos triangulares replicados por meio da reflexão deslizante e com uma faixa em ziguezague.

A imagem do painel gráfico destas tangas é, na maioria das vezes, estruturada dentro de uma área delimitada por linhas simples ou reticuladas que funcionam com uma espécie de moldura dentro da qual uma face é composta, conforme é possível observar na figura 82c. Esta face é elaborada sempre por três motivos, às vezes o mesmo motivo é usado para indicar olhos e nariz, mas também pode ocorrer que olhos sejam sugeridos por motivos idênticos e o nariz ser sugerido 
por um motivo diferente. Além disto, em todas estas tangas o espaço entre os olhos é sempre ocupado por motivos aludindo a um sauro, tridígítos ou volutas que formam o cenho. Bocas são sugeridas de várias formas, como por exemplo, pela repetição do padrão da banda 2 logo abaixo do painel gráfico, como se vê, por exemplo, nas figuras $81 \mathrm{~d}$ e 81 e.

As tangas vistas na figura 81 são as mais ilustrativas e características deste grupo. Seus painéis gráficos são sempre compostos por motivos que aludem a partes de seres, como linhas reticuladas com tridígitos, o motivo "cruz no medalhão" e figuras em espirais.

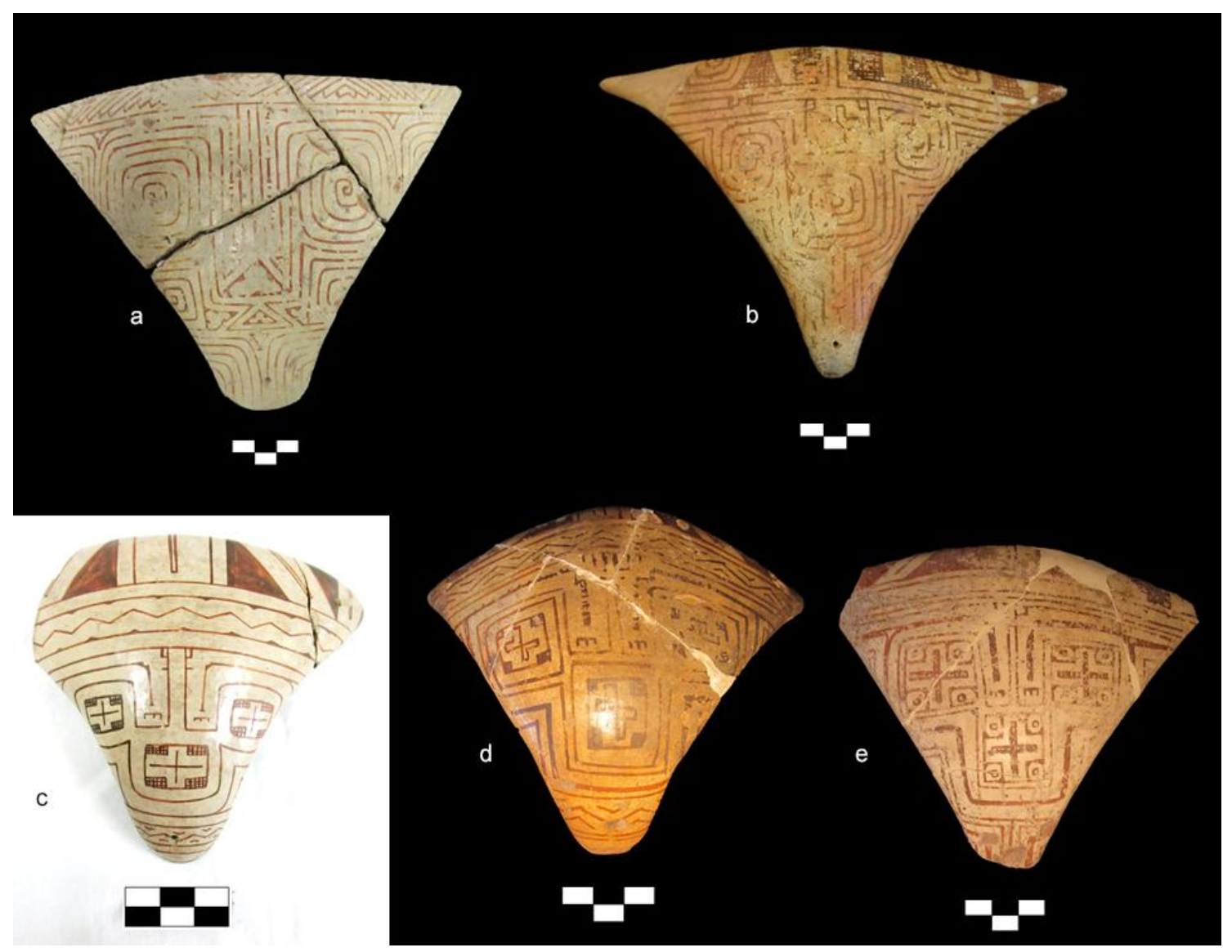

Figura 81. Tangas com padrões do painel gráfico constituídos por espirais e pelo motivo "cruz no medalhão".

a. Coleção Oliveira, Museu do Estado de Pernambuco, Recife.

b. Acervo do Sistema Integrado Museus e Memoriais/SECULT-PA, Belém.

c. Museu Nacional, Rio de Janeiro.

d. Museu Paraense Emílio Goeldi, Belém.

e. Coleção Dita Acatauassu, Museu Paraense Emílio Goeldi, Belém.

Estes motivos são sempre desdobrados e unidos ao centro por um outro, formando assim, uma face com olhos e nariz. Percebe-se que os olhos e nariz são 
sempre compostos por motivos iguais, com exceção daquela ilustrada na figura 81a, cujos olhos são em espirais, aludindo a um ser serpentelíneo, enquanto o nariz e a boca são triangulares, se assemelhando bastante também com aquelas ilustradas na figuras $82 \mathrm{~b}$ e $82 \mathrm{c}$.
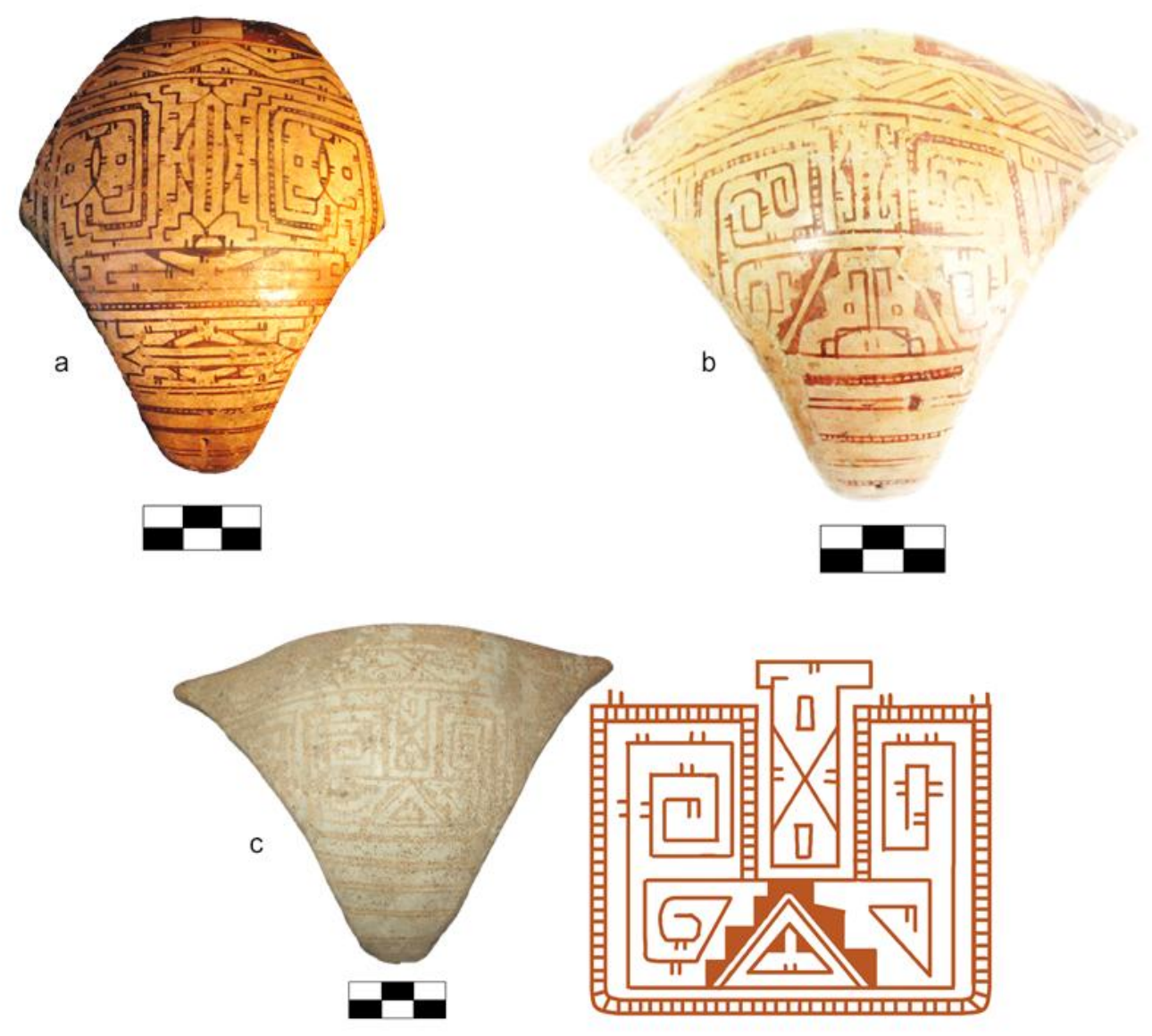

Figura 82. Tangas em que os padrões dos painéis gráficos aludem a uma face com olhos e nariz estruturados dentro de uma área delimitada por linhas reticuladas. Percebe-se que o cenho desta face é sugerido entre os olhos por figuras aludindo a sauros ou simplificações suas.

a. Museu Paraense Emílio Goeldi, Belém.

b. Museu Nacional, Rio de Janeiro.

c. Coleção ICBS/MAE-USP, Museu e Arqueologia e Etnologia, São Paulo.

Em um caso específico, o nariz é composto pela cabeça de uma figura que alude a um sauro e ao seu redor se desdobram duas pequenas faces com características felínicas, como aquelas vistas nas tangas do grupo 1 sugerindo o seus olhos (figura 82a). Nestas três tangas, o espaço entre os olhos é ocupado por motivos que aludem a um sauro, em alguns casos, bastante simplificado, compondo o cenho desta face. 
As três tangas ilustradas na figura 82, apresentam uma versão mais elaborada destas vistas acima. Em dois casos, por exemplo, o nariz é composto por motivos triangulares escalonados que aludem à cabeça do peixe-serpentelíneo e os são olhos sugeridos por volutas que se desdobram lateralmente a esta figura

Aqui, se percebe que as partes anatômicas das faces são compostas por figuras aludindo a cabeças de seres, como por exemplo, olhos compostos por uma pequena face com características de felinos (figura 82a), narizes aludindo à cabeça do peixe-serpentelíneo (figuras 82b e 16c). Nota-se ainda que é possível observar dentro destas faces/ cabeças outras figuras, tal como um sauro no interior da face felínica (figura 82a) ou uma pequena figura com "antenas" na cabeça dentro da cabeça do peixe-serpentelíneo (figura 82 b). Este é o mesmo princípio de encaixe recursivo de imagens que é visto nas tangas do grupo 1 usado para mostrar transformações. No entanto, em outras tangas a transformação é mostrada de outra forma.

O padrão visto nas tangas acima pode ser transformado, como pode ser visto nas tangas ilustradas na figura 83 , que exibem uma variação do motivo visto nas tangas ilustradas nas figuras $82 \mathrm{~b}$ e $82 \mathrm{c}$. Nelas, o motivo é transformado por meio da rotação e da reflexão, como é possível notar comparando-se as figuras 82b e 82c com as figuras 83a1 e 83a2.

Embora já tenhamos comentado em outro momento, é importante destacar que o desdobramento deste motivo alude a uma transformação, onde a cabeça do peixe-serpentelíneo se transforma no corpo losangular do sauro-humano e os seus barbilhos nos seus membros. A associação de motivos que aludem à cabeça do peixe-serpentelíneo ou a partes suas com a figura do sauro-humano também ocorre em tangas de outros grupos, como por exemplo, algumas do grupo 5 . 

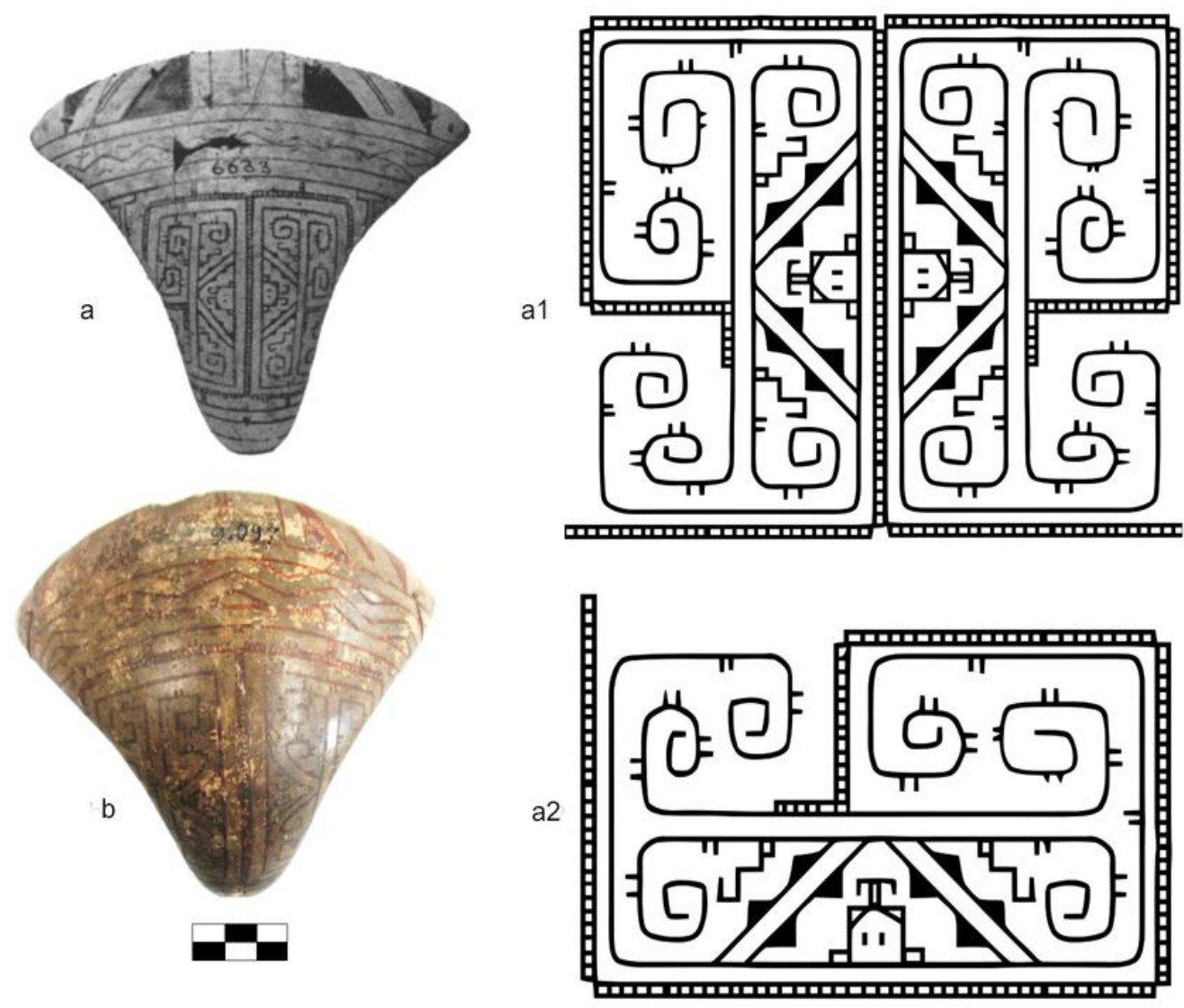

Figura 83. Tangas com padrão de face no painel gráfico formado pelo desdobramento do motivo que alude à cabeça do peixe-serpentelíneo.

a. Tanga com motivo que alude à cabeça do peixe-serpentelíneo desdobrado. Peabody Museum of Archaeology and Ethnology, Havard. Fonte: Palmatary, 1950: 460.

a1. Rollout do padrão visto na tanga da figura $A$ mostrando uma transformação do peixe-serpentelíneo, por meio do desdobramento, que ao mesmo tempo em que mostra uma face, alude à presença do sauro-humano.

a2. Motivo "dobrado" da cabeça do peixe-serpentelíneo conforme visto em outras tangas deste grupo.

b. Tanga com o mesmo motivo desdobrado. Museu Nacional, Rio e Janeiro.

\subsection{As tanga do Grupo 5}

Este grupo abrange 9 tangas cujo painel gráfico exibe a imagem de uma face estruturada em três áreas por meio da delimitação de grandes espaços losangulares e, mais raramente, triangulares, em suas laterais, o que cria um espaço central entre estas duas áreas laterais. A maior parte é composta por motivos em espirais que aludem a seres serpentelíneos e muitas vezes, motivos simplificados aludindo a sauros.

As tangas analisadas abrangem cinco coleções depositas em três diferentes instituições, como pode ser visto na tabela abaixo. 


\begin{tabular}{|c|c|c|}
\hline \multicolumn{3}{|c|}{ Tangas do grupo 5 } \\
\hline Coleção/ Instituição & Quantidade & Procedência \\
\hline ICBS/MAE-USP & 1 & Tesos Urubu e Camutins \\
\hline Coleção Plínio Airosa/ MAE-USP & 1 & indeterminada \\
\hline Museu Paraense Emílio Goeldi & 1 & Teso Pacoval \\
\hline $\begin{array}{c}\text { Coleção Dita Acatauassu/ Museu } \\
\text { Paraense Emílio Goeldi }\end{array}$ & 2 & Teso Severino \\
\hline $\begin{array}{c}\text { Coleção Oliveira/ Museu do Estado de } \\
\text { Pernambuco }\end{array}$ & 1 & \\
\hline
\end{tabular}

Também foram incorporadas outras três tangas, duas da Coleção Governo do Estado do Pará, em Belém, e outra do Denver Art Museum, em Denver.

Destas, cinco são de morfologia 2 e três são de morfologia 1. Quanto ao seu layout, estas tangas não necessariamente apresentam uma homogeneidade em relação à quantidade de campos gráficos. Ás vezes podem apresentar a banda 1, a banda 2, o painel gráfico e as linhas, às vezes não possuem apenas a banda 2 , outras vezes só apresentam o painel gráfico e as linhas, mas também podem apresentar só o painel gráfico, ou seja, variam bastante.

O painel gráfico destas tangas sempre mostra uma face cujas características variam em função da forma como os motivos são desdobrados dentro do campo. 

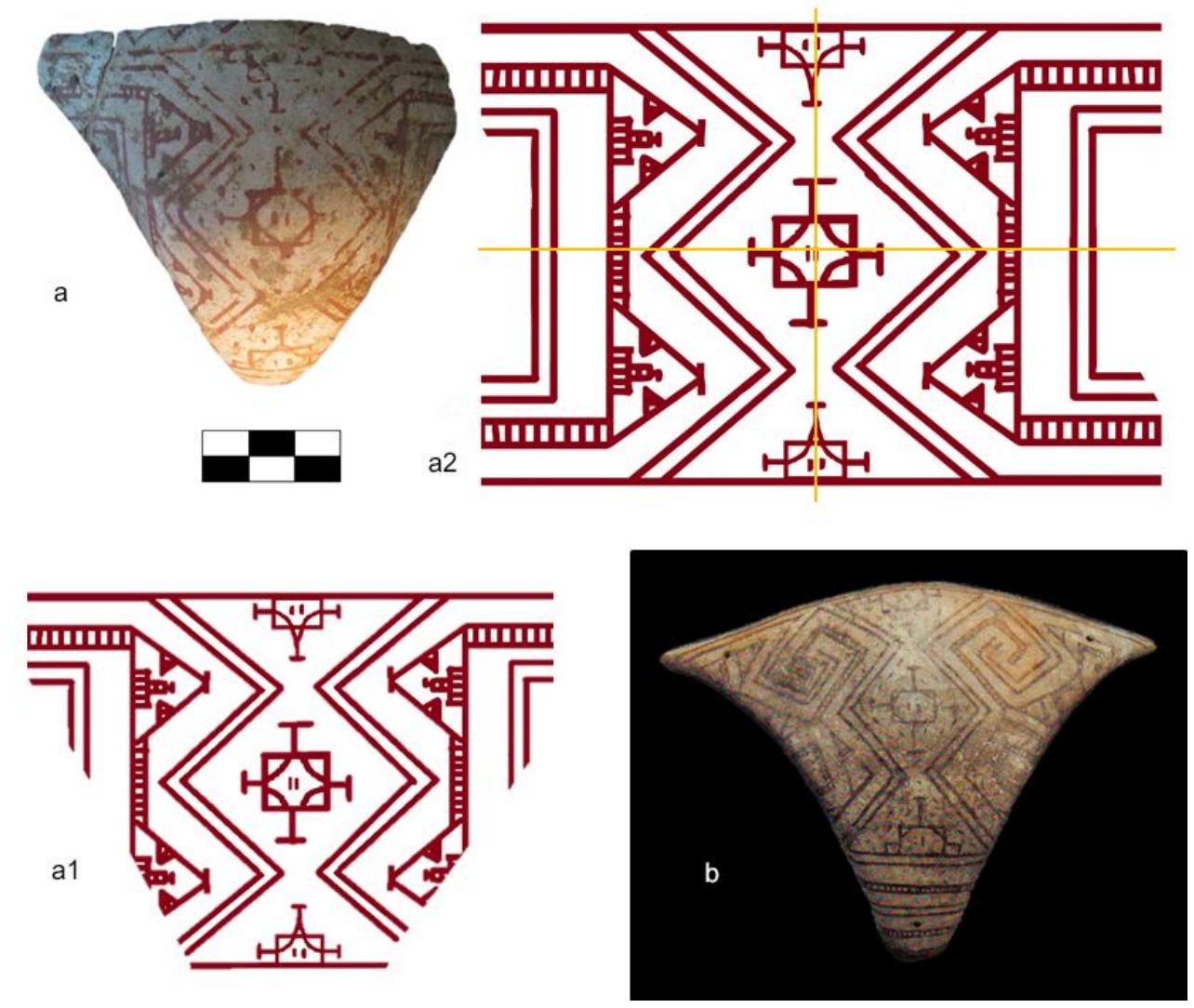

Figura 84. Tangas desdobradas em dois eixos simétricos perpendiculares.

a. Coleção Dita Acatauassu, Museu Paraense Emílio Goeldi, Belém.

a1. Reconstituiçaõ do padrão do painel gráfico.

a2. Rollout reconstituindo o desdobramento do padrão em dois eixos perpendiculares.

b. Denver Art Museum, Denver. Fonte: Young-Sánchez e Schaan, 2011.

Em três destas tangas, o padrão é estruturado pelo desdobramento de um motivo em dois eixos perpendiculares, como é visto na figura 84a2. Embora seja mais comum que a imagem de face tenha os seus olhos compostos por espirais losangulares aludindo a seres serpentelíneos (figura 84b), em um caso específico, os olhos são sugeridos por um motivo que pode aludir ao peixe-serpentelíneo (figura 84a).

Percebe-se que enquanto na figura $84 \mathrm{~b}$ o ser serpentelíneo é sugerido pelas espirais reticuladas losangulares, na figura $84 a$ é possível também ver a sua cabeça, onde uma pequena linha sugere os seus barbilhos, além de parte do seu corpo reticulado. Ou seja, o mesmo ser é figurado de maneiras diferentes, ora só mostrando o seu corpo, ora mostrando a sua cabeça e parte do seu corpo, em tangas com a mesma estrutura, a fim de sugerir uma parte anatômica de um corpo, isto é, olhos. 
Já em quatro outras tangas ocorre uma reelaboração do padrão visto acima. Nelas, motivos losangulares em espirais são desdobrados em um único eixo simétrico, sugerindo grandes olhos, e a área entre estes motivos é estruturada em forma de $X$, onde são dispostos elementos diversos para estruturar 0 cenho, o nariz e a boca (figura 85).

Nestas tangas, no espaço entre os olhos, ao mesmo tempo em que a boca, o nariz e cenho estão presentes, se vê figuras aludindo ao sauro-humano escondidas. Na tanga ilustrada na figura 85a, por exemplo, os elementos retangulares, ao mesmo tempo em que aludem ao cenho, boca e nariz, formam a cabeça de uma figura cujo corpo é sugerido na própria estrutura em forma de $X$ entre os olhos. Percebem-se os

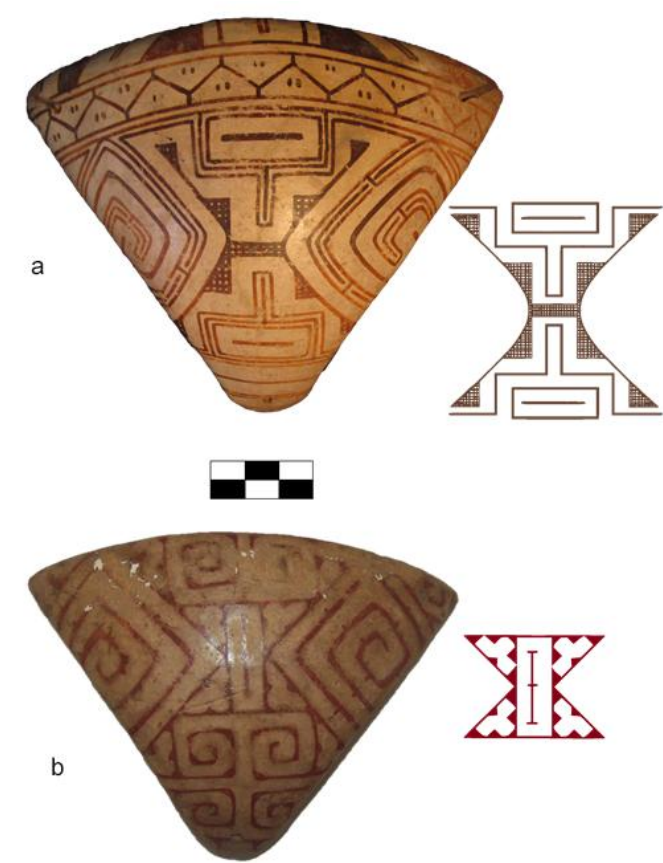

Figura 85. Tangas estruturadas em três áreas por meio da disposição de motivos em forma de espirais losangulares em suas laterais.

Belém.

a. Museu Paraense Emílio Goeldi,

b. Museu de Arqueologia e membros estendidos e a cabeça duplicada comum nas figurações do sauro-humano, como já comentado.

A configuração das imagens vistas nestas tangas, delimitadas em três áreas, ou seja, uma central e duas laterais, além da localização da figura que alude ao sauro-humano na área central, é semelhante ao que ocorre nas tangas do grupo 1. Lembremo-nos que naquelas tangas, da mesma forma, nariz, boca e cenho coincidem com a figura do sauro-humano e que os olhos são pequenas faces que se abrem mostrando figuras de sauros, mas cuja estrutura geral, poderia aludir a uma face felínica.

É importante destacar que não são raras as figurações em que seres sepentelíneos são estruturados para sugerir a figura do sauro. Na tanga ilustrada na figura 95b do grupo 8, por exemplo, o dorso do sauro é sugerido por meio de um ser serpentelíneo enrolado, assim como visto nas tangas acima ilustradas. Além disto, em certas tangas do grupo 4 , como aquelas vistas na figura 83 , um motivo em forma 
de pirâmide escalonada aludindo à cabeça do peixe-serpentelíneo é desdobrado, de modo que as cabeças espelhadas se transformam no tronco losangular do saurohumano, e os barbilhos daquele ser, sugeridos por volutas, se transformam em seus membros. Deste modo, é possível que o motivo em espiral losangular aludindo a um ser serpentelíneo, compondo os olhos nas imagens de faces vistas nestas tangas, também seja uma alusão à figura do sauro-humano.

Deste modo, apesar destas tangas não apresentarem transformações agenciadas por meio do encaixe múltiplo de imagens, como aquelas do grupo 1 , ainda assim apresentam semelhanças notáveis com aquelas. Conforme comentamos, ambas possuem as imagens dos painéis gráficos estruturadas em três áreas, sendo que na área central, a figura do sauro-humano sobrepõem-se ao cenho, nariz e boca. Também mas tangas do grupo 1, as figuras dos painéis laterais são olhos e ao mesmo tempo uma face felínica que se abre e mostra uma figura de sauro em seu interior. Já nestas tangas, as figuras que aludem aos olhos não se transformam no plano da visão, mas sim com base na abdução da agência, com a transformação do ser serpentelíneo no sauro. Deste modo, ambas possuem os painéis gráficos estruturados em 3 áreas, com um motivo aludindo ao sauro-humano no centro da imagem e, além disto, os motivos laterais que configuram os olhos agenciam algum tipo de transformação.

\subsection{As tangas do grupo 6 .}

Este grupo abrange 14 tangas cujos painéis gráficos apresentam imagens compostas, algumas vezes por motivos em forma de seta, aludindo a um ser serpetelíneo, e por volutas, e outras, pelo motivo "cruz no medalhão" e por motivos em $\mathrm{T}$, sempre construídas a partir de uma área retangular delimitada ao centro do painel gráfico e estruturadas por dois eixos que se cruzam, sendo um deles virtual (figura 86). 

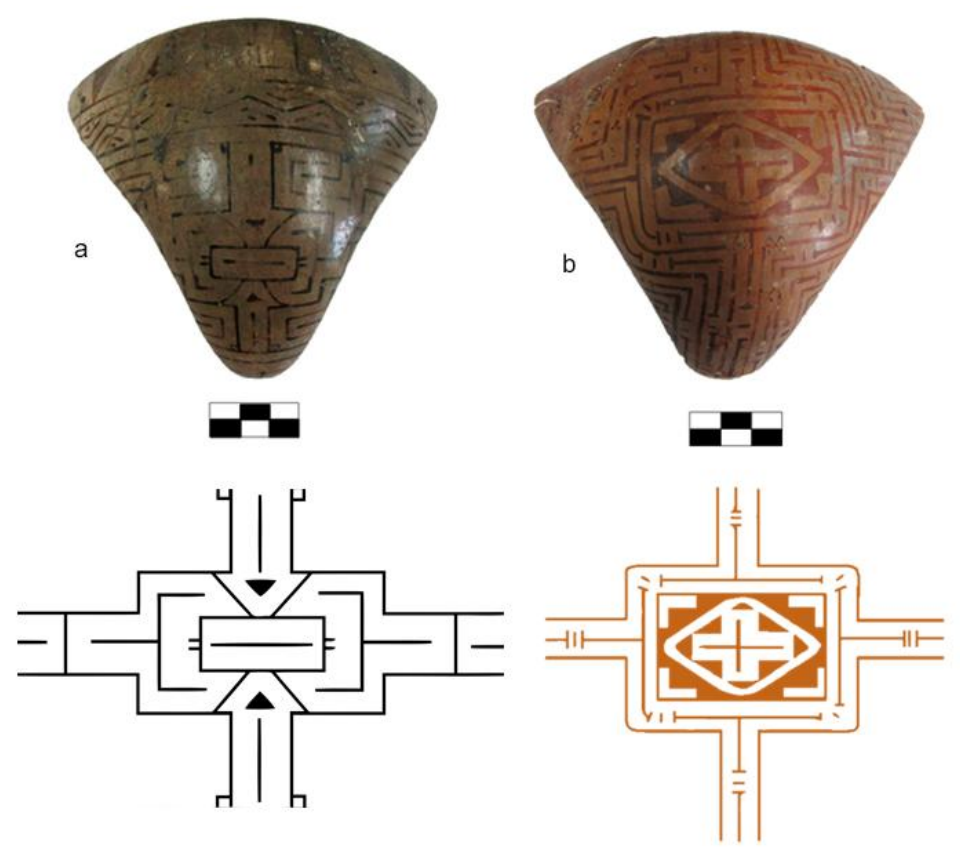

Figura 86. Imagens estruturadas a partir de uma área central retangular em dois eixos perpendiculares de simetria. a, b. Museu Nacional, Rio de Janeiro.

As coleções analisadas que abrangem as peças deste grupo podem ser vistas na tabela abaixo.

\begin{tabular}{|c|c|c|}
\hline \multicolumn{3}{|c|}{ Tangas grupo 6 } \\
\hline Coleção/ Instituição & Quantidade & Procedência \\
\hline ICBS/ MAE-USP & 2 & $\begin{array}{l}\text { Fazenda São Marcos, tesos } \\
\text { Camutins e Urubu (1 tanga) }\end{array}$ \\
\hline Museu Nacional & 6 & Indeterminada \\
\hline $\begin{array}{c}\text { Coleção Dita Acatauassu, } \\
\text { Museu Paraense Emílio Goeldi }\end{array}$ & 3 & \\
\hline
\end{tabular}

Também foram incorporadas três outras tangas, uma da Antiga coleção Instituto Cultural Banco Santos, Museu Nacional de Etnologia, em Lisboa e outra do American Museum of Natural History, em Nova York.

Destas tangas, nove são de morfologia 1 e cinco de morfologia 2. A maior parte das tangas de morfologia 1, apresenta os quatro campos gráficos, ou seja, banda 1, banda 2, painel gráfico e linhas horizontais nas extremidades. Neste caso, a banda 1 caracterizada pelo padrão do tipo 1a, isto é, por faixas brancas verticais e oblíquas formadas pela justaposição de triângulos ou trapézios preenchido por tinta, 
enquanto a banda 2 é composta por variantes do padrão formado por elementos triangulares refletidos por meio da reflexão deslizante de modo a formar uma faixa em ziguezague.

Entre aquelas de morfologia 1, três apresentam a banda 1, painel gráfico e linhas. Neste caso, o padrão da banda 1 é diferente em cada uma. Três tangas que apresentaram apenas o painel gráfico apresentam variantes do padrão ilustrado na figura 14b,e delas duas são de morfologia 2 e uma de morfologia 1.

Este grupo abrange tangas com dois padrões distintos, mas conforme já comentado, estruturadas de maneiras semelhantes, como pode ser observado na figura 86. Enquanto que na maior parte delas a imagem é construída pelo desdobramento de uma figura serpentilínea, em três tangas específicas vemos figuras em T desdobradas e unidas pelo motivo "cruz no medalhão", resultando em uma imagem que parece ser uma simplificação daquelas compostas pelo desdobramento do ser serpentelíneo (figura 86b). No entanto, em ambos os casos, este desdobramento de certos motivos forma uma estrutura retangular a partir da qual o restante da imagem é construída, seja por volutas, seja por linhas. Como é possível observar na ilustração 87 , nestas tangas, o desdobramento a partir de dois eixos perpendiculares, assim como já vimos em outros grupos, cria duas imagens opostas que são unidas por um elemento.

É importante destacar que a imagem do painel gráfico de todas estas tangas é estruturada por meio do desdobramento em dois eixos perpendiculares, um deles, assim como já visto em outras tangas, só é perceptível com a reconstituição das partes apenas sugeridas, como é possível observar na figura 87. 


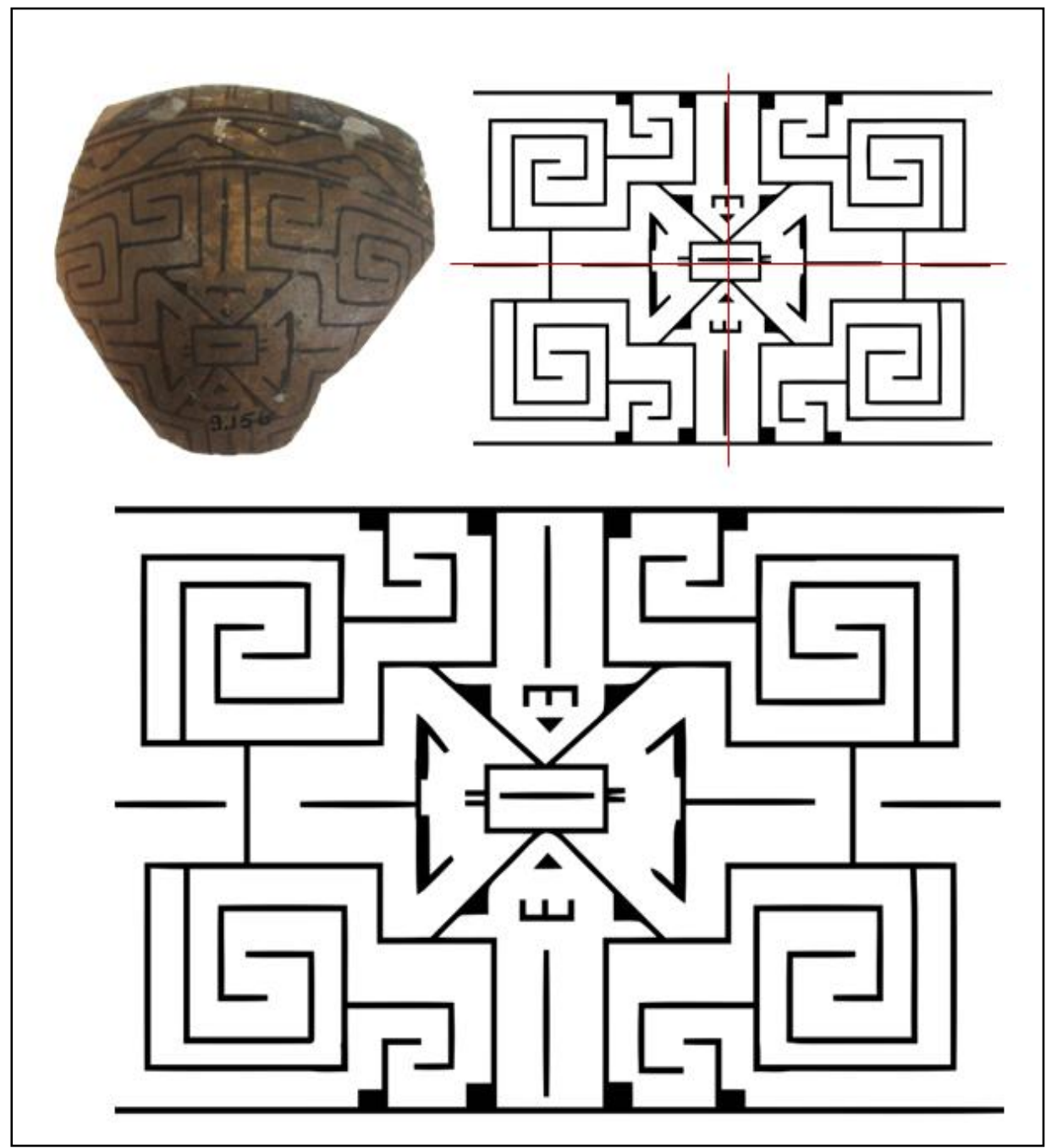

Figura 87- Rollout destacando a formação de uma face por meio do desdobramento em dois eixos perpendiculares, um deles virtual, da figura do peixe-serpentilíneo. Museu Nacional, Rio de Janeiro.

A maior parte destas tangas apresenta uma imagem no painel gráfico que alude a uma face felínica, com olhos, nariz, boca e um elemento espiralado que ora pode ser interpretado como orelhas, ora como um adorno auricular (figura 88). Estas características faciais são constituídas por figuras sepentilíneas ladeadas por volutas que poderiam aludir ao peixe-serpentelíneo.. 


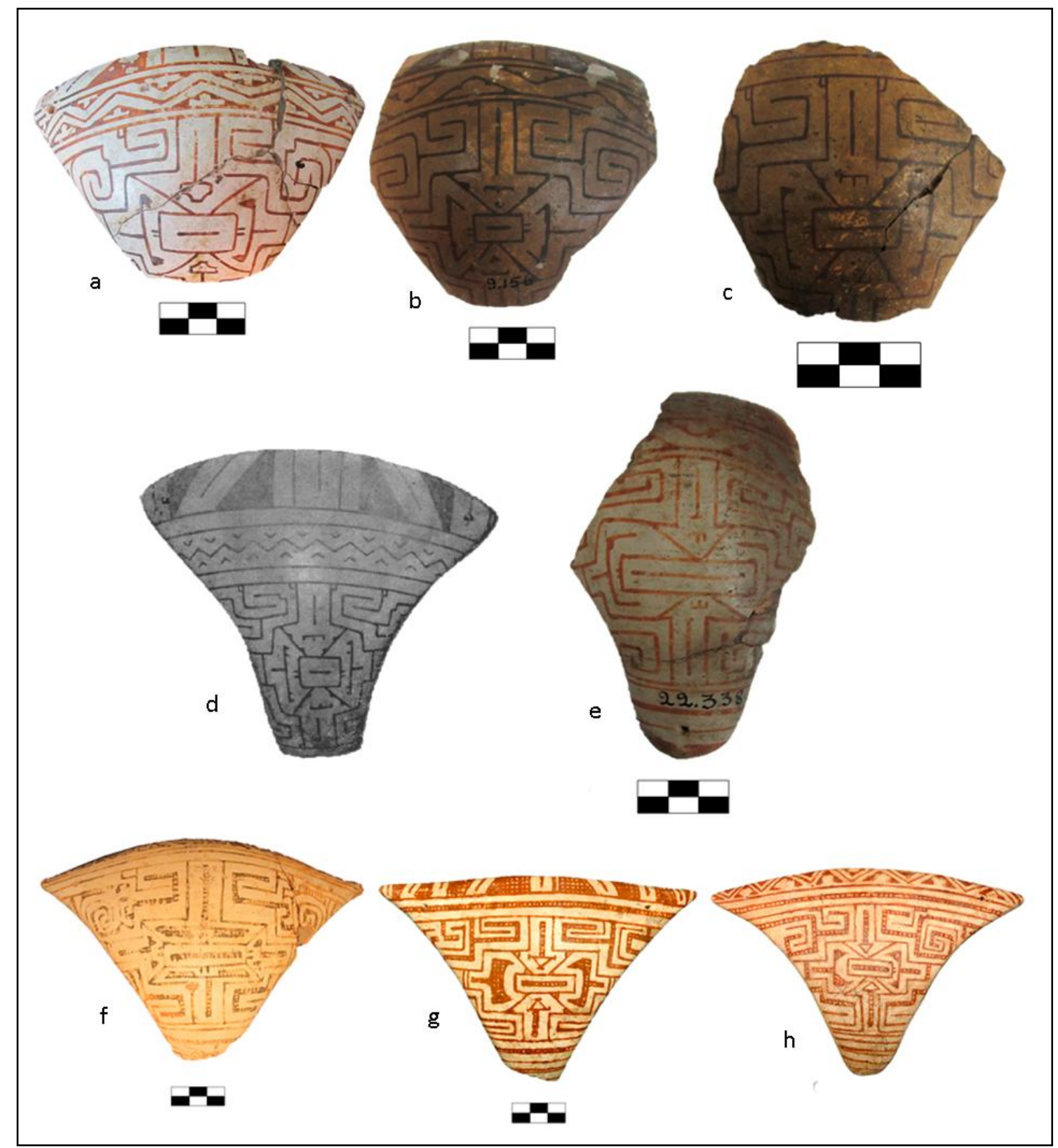

Figura 88- Tangas cujo padrão alude a uma face estruturada a partir do desdobramento de figuras serpentilíneas.
a, f. Coleção Museu Paraense Emílio Goeldi, Belém.
b, c, e. Museu Nacional, Rio de Janeiro.
d. American Museum of Natural History, Nova York. Fonte: Palmatary, 1950: 103.
g. Coleção ICBS/MAE-USP, São Paulo.
h. Antiga Coleção Instituto Cultural Banco Santos.

\subsection{As tangas do grupo 7}

Este grupo abrange 14 tangas, todas com imagens compostas por várias simplificações por figuras de seres, como por exemplo, elementos em T e volutas, e estruturadas por meio da reflexão ou pelo desdobramento. 


\begin{tabular}{|c|c|c|}
\hline \multicolumn{2}{|c|}{ Tangas grupo 7 } \\
\hline Coleção/ Instituição & Quantidade & Procedência \\
\hline ICBS/ MAE-USP & 4 & $\begin{array}{c}\text { Fazenda São Marcos, tesos } \\
\text { Camutins e Urubu }\end{array}$ \\
\hline Museu Nacional & 5 & Indeterminada \\
\hline $\begin{array}{c}\text { Museu Paraense Emílio } \\
\text { Goeldi }\end{array}$ & 1 & indeterminada \\
\hline $\begin{array}{c}\text { Museu do estado de } \\
\text { Pernambuco }\end{array}$ & 1 & Teso Severino \\
\hline
\end{tabular}

Foram incorporadas também na análise três tangas, sendo uma da Coleção Governo do Estado do Pará, em Belém, uma do Departamento de Antropologia da Cornell University, em Ithaca, e uma do National Museum of American Indian, em Washington.

Destas 14 tangas, nove são de morfologia 1 e são estruturadas em quatro campos gráficos. Nestas, a banda 1 é sempre ocupada pelo padrão do tipo 1a, e banda 2 apresenta padrões do tipo 3, com exceção da tanga ilustrada na 17c que apresenta a banda caracterizada por um padrão do tipo 2. Outras cinco tangas são de morfologia 1, caracterizadas por banda 1 e painel gráfico.

As imagens constituídas no painel gráfico destas tangas, como comentado, são compostas por vários elementos comuns, no entanto, as características exibidas são resultantes de enquadramentos diferentes do padrão gráfico virtual. Para se ter uma ideia, as duas tangas ilustradas na figura 89 são compostas por dois eixos de simetria perpendiculares, como pode ser visto na figura 89. Nos dois casos há figuras em $T$ que são desdobradas verticalmente, e entre elas há outra figura, no caso da figura 89a, o motivo "cruz no medalhão", e no caso da figura 89b, um motivo que alude ao sauro-humano. Estas imagens são estruturadas pelo desdobramento em um eixo horizontal destes motivos, e no espaço entre um e outro são formadas novas figuras, conforme é possível observar no rollout mostrado na figura 90.

Deste modo, é possível perceber, que enquanto na tanga vista na figura 89a o padrão virtual foi enquadrado priorizando-se a centralidade do motivo, na tanga ilustrada em 89b, o enquadramento priorizou a figura entre o motivo, ou seja, as imagens focalizam partes diferentes do padrão. É importante destacar que, independentemente da forma como estas imagens são enquadradas elas sempre 
exibem uma figura de face. $O$ enquadramento só determina qual figura será mostrada graficamente e qual figura será mostrada virtualmente, conforme pode ser observado nas ilustrações abaixo.

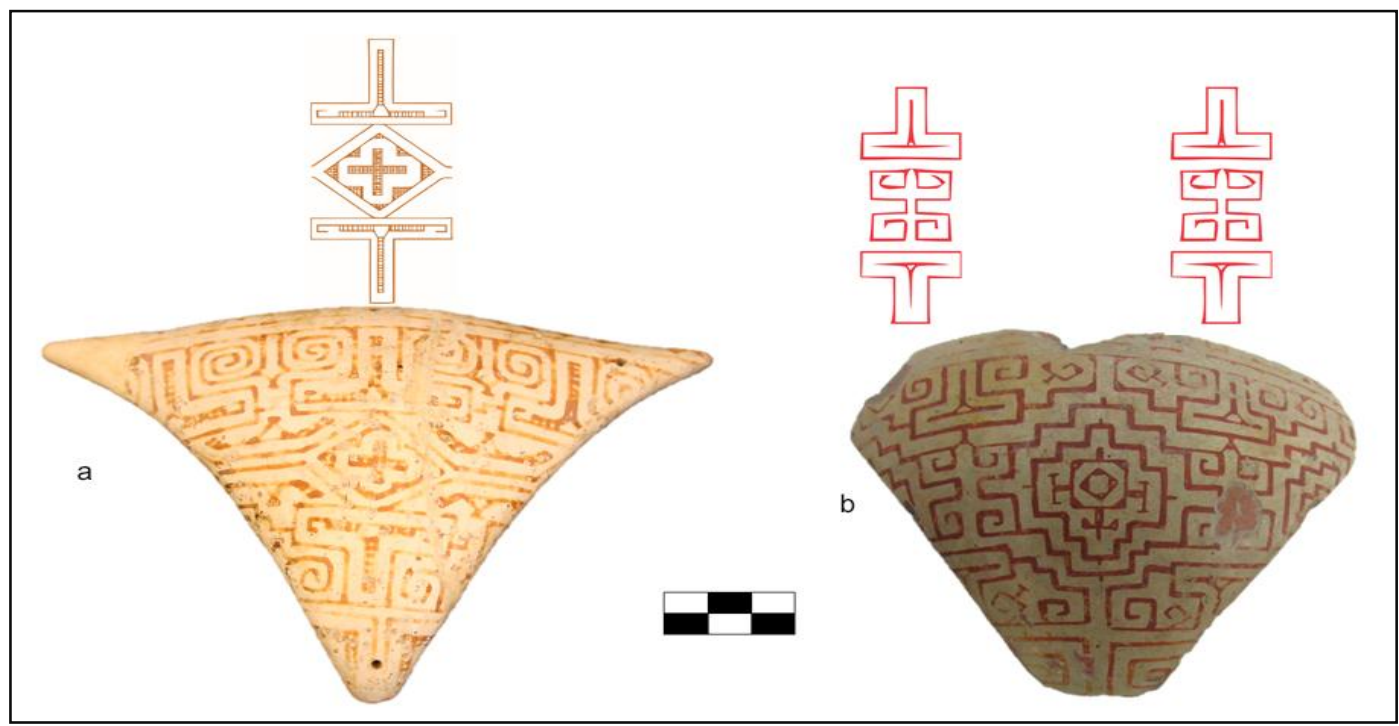

Figura 89. Imagens compostas por motivos semelhantes, mas exibindo enquadramento de partes diferentes do padrão virtual. Percebe-se que a posição dois motivos acima destacados diferem nas duas tangas, com um localizado ao centro do painel, e outro localizado em suas laterais.

a. Coleção Governo do Estado do Pará, Belém.

b. Coleção Oliveira, Museu do Estado de Pernambuco, Recife.
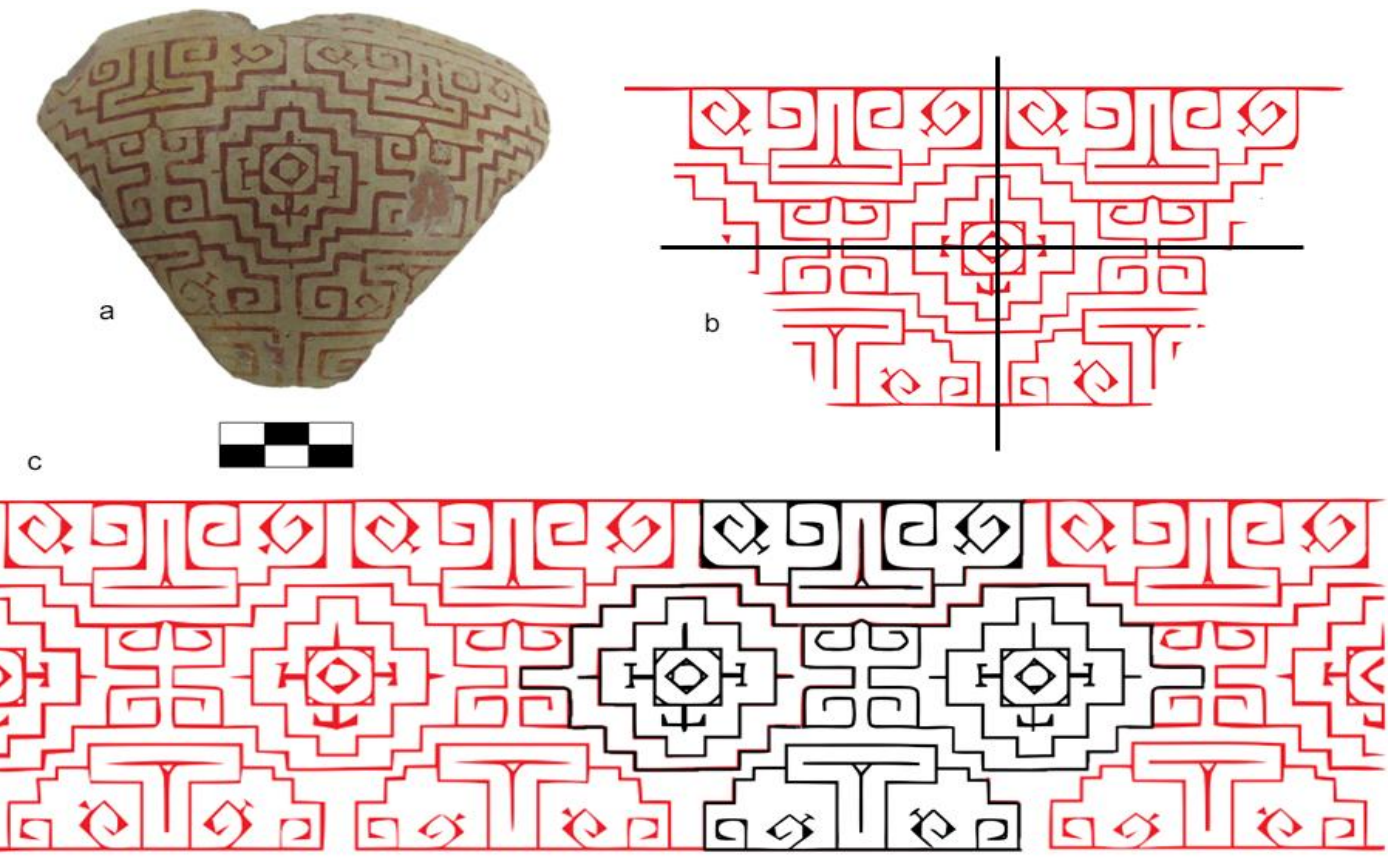

Figura 90. Figuras escondidas no padrão virtual.

a. Acervo do Museu do Estado de Pernambuco, Recife.

b. Rollout da imagem do painel gráfico destacando os eixos de desdobramento.

c. Rollout destacando as figuras que são formadas no padrão virtual. 
Um arranjo diferente deste padrão é visto em outras tangas, como pode ser observado na figura 91. Aqui, a imagem é resultante de um enquadramento que prioriza uma parte mais restrita ainda do padrão virtual.
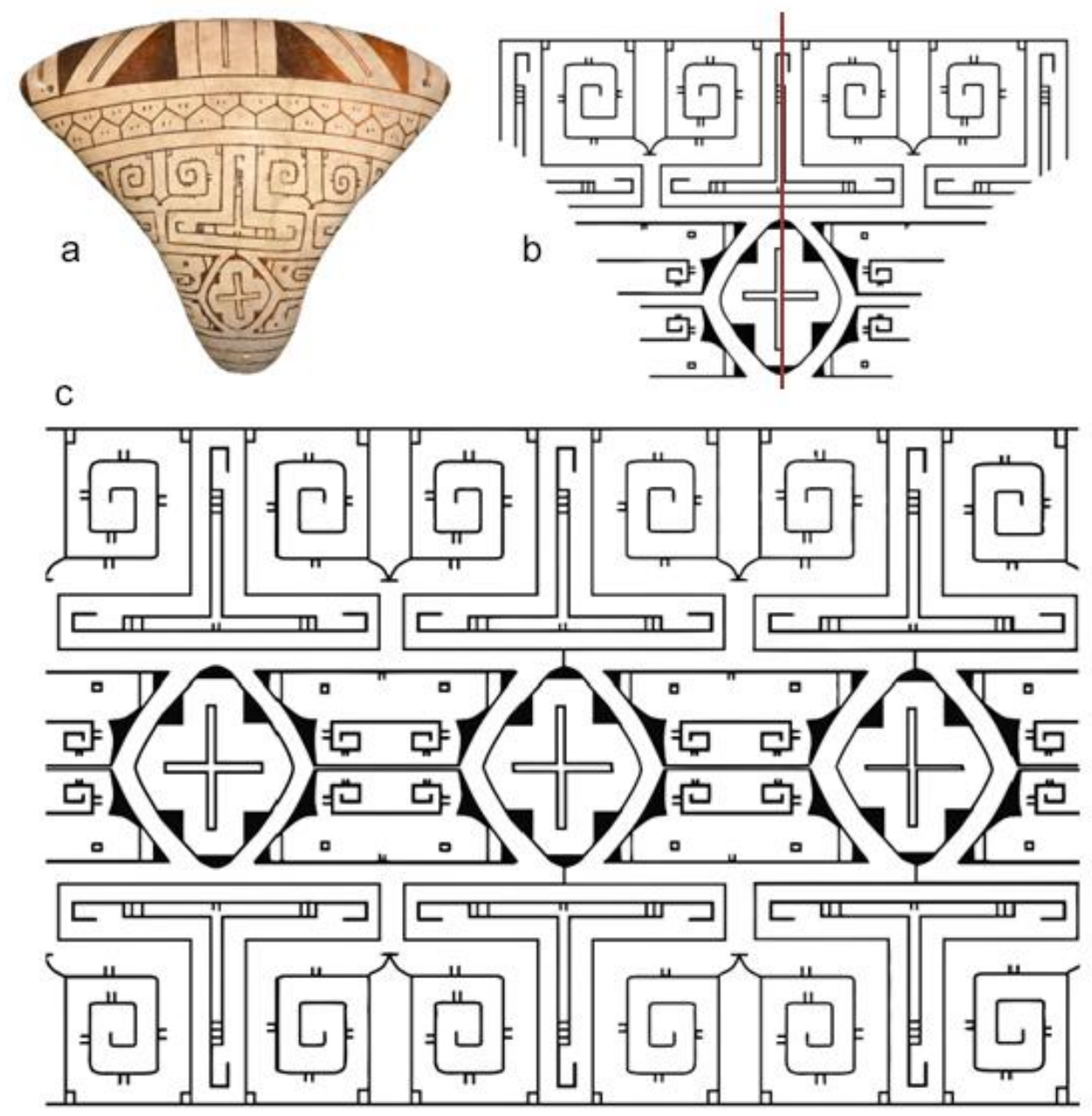

Figura 91. Imagem desdobrada em apenas um eixo de simetria.

a. Coleção ICBS/ MAE-USP, Museu de Arqueologia e Etnologia, São Paulo.

b. Rollout da imagem destacando o eixo de simetria pelo qual é desdobrada.

c. Rollout do padrão virtual.

Neste caso específico, a imagem sempre mostra uma face, cujos olhos são sugeridos por um ser com membros em forma ganchos ou volutas que poderia aludir a um sauro, nariz pelo motivo em $T$ invertido e bocas por motivos em espirais ou pelo motivo "cruz no medalhão"(figura 91 e figura 92). 


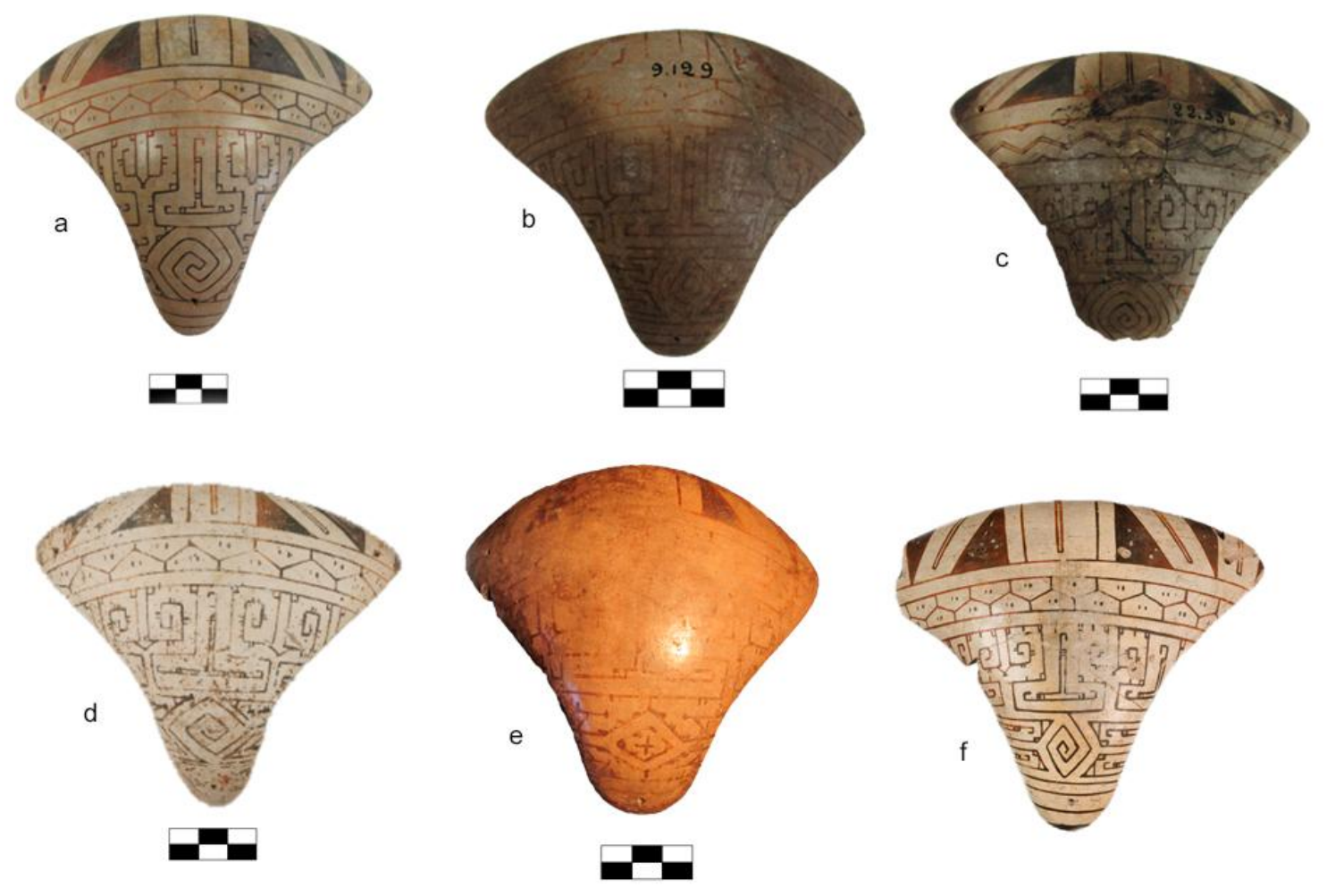

Figura 92. Tangas cujas imagens dos painéis gráficos destacam um enquadramento do padrão.
a, b, c. Museu Nacional, Rio de Janeiro.
d. National Museum of American Indian, Washignton.
e. Museu Paraense Emílio Goeldi, Belém.
f. Departamento de Antropologia da Cornell University.

Estas imagens, ora estruturadas com dois eixos de simetria, ora com um único eixo, e priorizando enquadrar diferentes partes de um padrão virtual, que pode ser mostrado integralmente ou em parte, ilustram o caráter quimérico dos grafismos vistos nas tangas deste grupo e destacam, sobretudo, a relação entre aquilo que é visto e aquilo que é apenas sugerido.

\subsection{As tangas do grupo 8}

Este grupo abrange 13 tangas, todas caracterizadas por composições que utilizam o mesmo motivo, ou variantes dele, no painel gráfico. Todas são de morfologia 1 e são estruturadas com os quatro campos já descritos, banda 1, banda 2, painel gráfico e linhas, com exceção de uma, que possui apenas três campos. A banda 1 é caracterizada sempre pelo padrão 1 composto por meio de faixas brancas obliquas alternadas com trapézios ou triângulos pintados, enquanto a banda 2 é 
sempre ocupada por padrões do tipo "b" e "c" já descritos anteriormente com maior predominância de padrões do tipo "b", isto é, padrões compostos por meio da replicação de triângulos por reflexão deslizante, criando deste modo, uma faixa em zigue-zague.

As tangas analisadas deste grupo estão distribuídas em dois museus, abrangendo três coleções museus, como pode ser visto na tabela abaixo, no entanto salientamos que a maior parte das peças analisadas é do Museu Nacional.

\begin{tabular}{|c|c|c|}
\hline \multicolumn{3}{|c|}{ Tangas do grupo 8 } \\
\hline Coleção/ Instituição & Quantidade & Procedência \\
\hline $\begin{array}{c}\text { Coleção Amazônica/ } \\
\text { Museu Nacional }\end{array}$ & 7 & Indeterminada \\
\hline ICBS/ MAE-USP & 1 & $\begin{array}{c}\text { Tesos Camutins e } \\
\text { Urubu }\end{array}$ \\
\hline 006/ MAE-USP & 1 & Pacoval \\
\hline
\end{tabular}

Também incorporamos 4 tangas publicadas em livros e catálogos, uma do Museum of Archaeology and Ethnology, em Cambridge, uma do Museum für Völkerkunde e uma do National Museum of American Indian, em Washington, todas provenientes do Pacoval, além de uma peça da antiga coleção Barbier-Mueller.

Os motivos do painel gráfico destas tangas podem ser estruturados por meio de quadrantes ou painéis horizontais, com exceção de uma em que os motivos são estruturados em painéis verticais. Todas são compostas por um motivo que alude à figura do sauro, bastante simplificado e caracterizado por um elemento losangular sugerindo o seu tronco e com membros em forma de tridentes que, ora podem estar voltados contra o tronco, ora podem estar voltados para o tronco, dependendo da variante, conforme pode ser notado na ilustração abaixo (figura 93). 


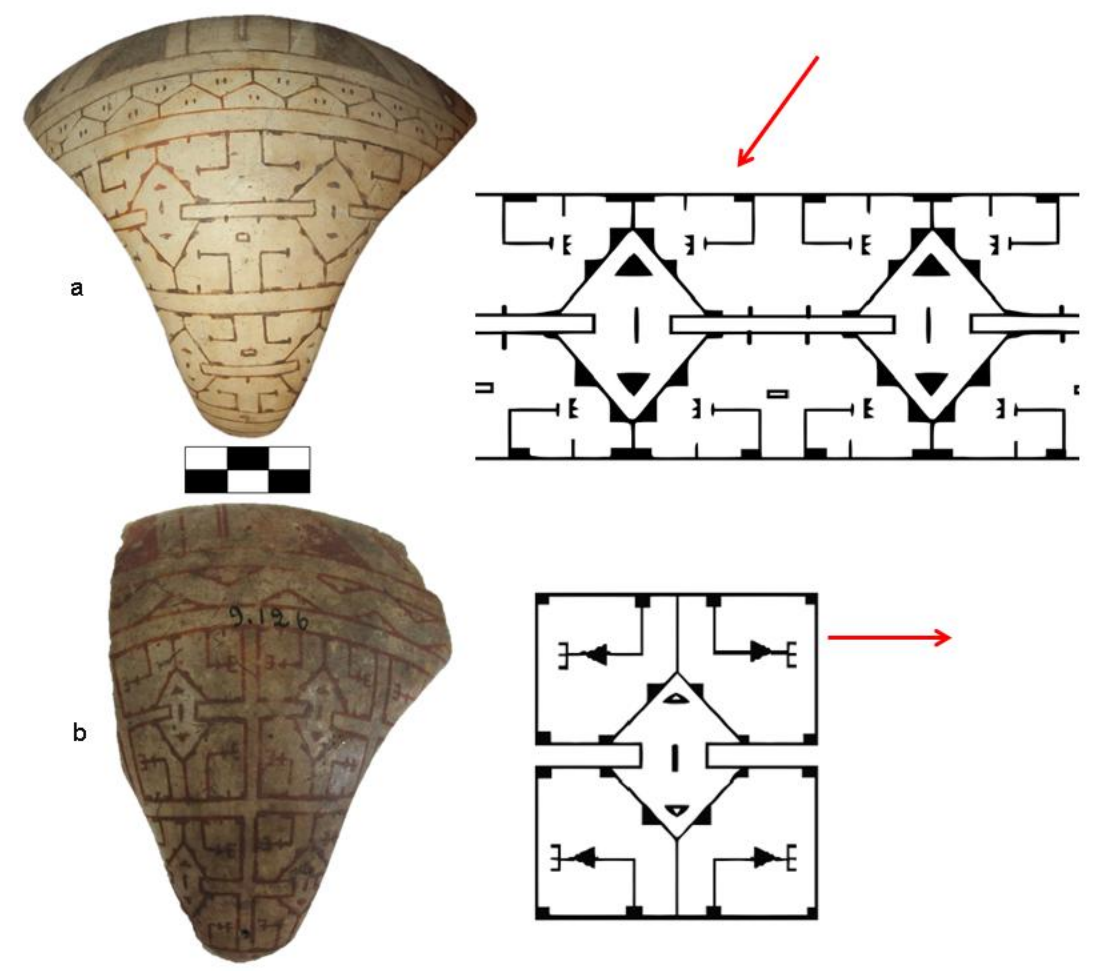

Figura 93. Formas de estruturar os motivos das tangas deste grupo. As setas vermelhas destacam a direção para a qual os membros da figura que alude ao sauro estão voltados.

a. Coleção ICBS/MAE-USP, São Paulo.

b. Museu Nacional Rio de Janeiro

Como se nota na ilustração acima (figura 93) as duas variantes do motivo são estruturalmente diferentes, enquanto na variante "a" a figura do sauro é estruturada dentro de painéis horizontais, um superior e outro inferior, na "b" é estruturada em quadrantes. Nota-se também que enquanto na variante "b" as linhas formadas entre os quadrantes desdobrados atravessam a imagem criando dois eixos perpendiculares, na variante "a" o eixo vertical é sugerido virtualmente entre os membros das figuras do sauro, ao passo que um eixo horizontal é sugerido no espaço entre os dois painéis. Percebe-se, deste modo, imagens muito semelhantes, compostas pelo mesmo motivo, mas por princípios estruturais diferentes.

Nos dois casos, a forma como os motivos que aludem ao sauro são estruturados cria uma face com todos os atributos das faces marajoara, ou seja, olhos, cenho nariz e boca. No entanto, como se vê na imagem abaixo, somente os olhos são dados ao olhar em todas as tangas, sendo sempre estruturados pelo tronco lonsagular do sauro (figura 94). 

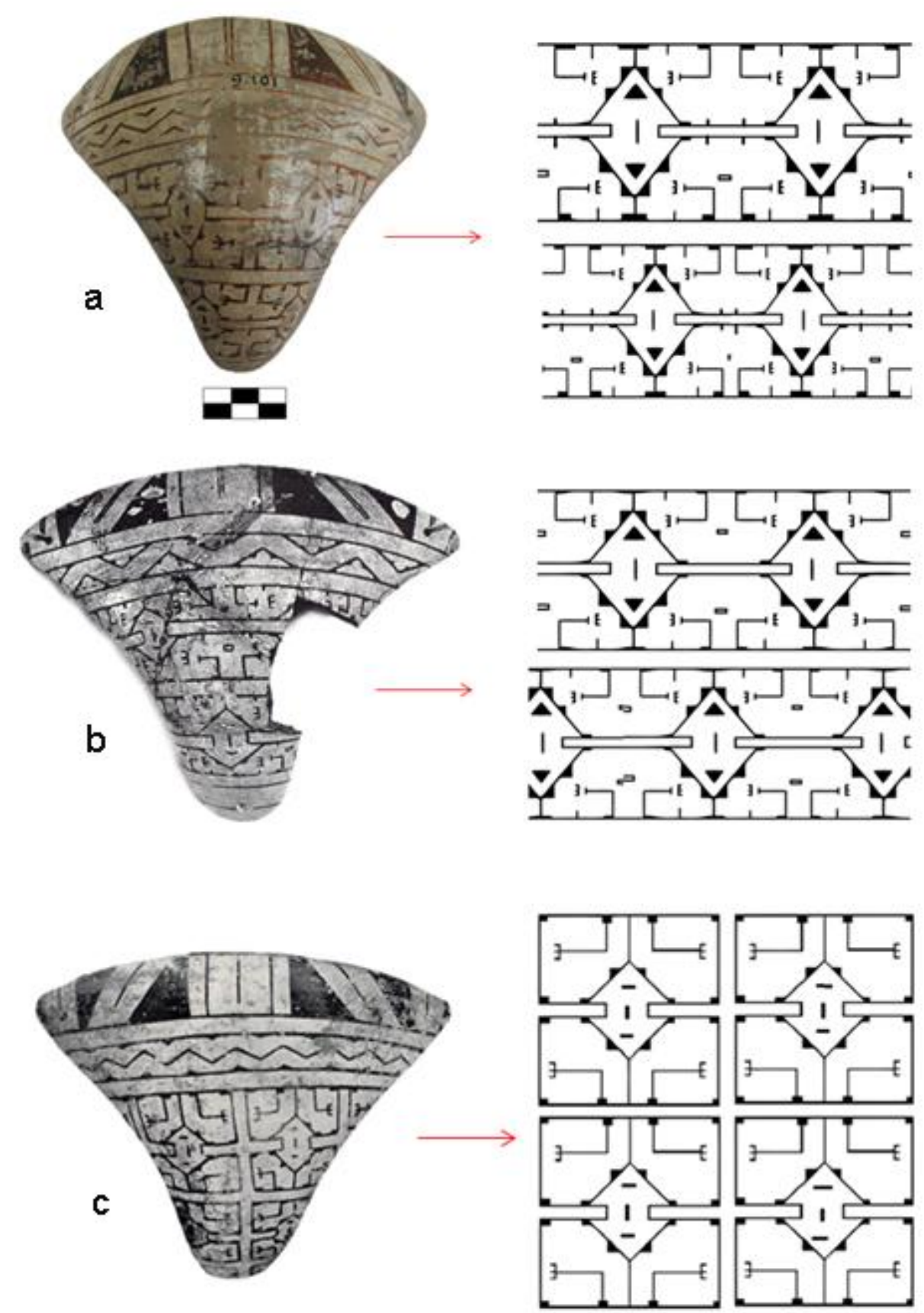

Figura 94. Diferentes modos de estruturar o campo gráfico para compor uma imagem de face.

a. Museu nacional, Rio de janeiro.

b.University Museum of Archaeology e Etnology, Cambridge. Fonte: Mordini: 1929, prancha 3.

c. Museum für Völkerkund, Berlin. Fonte: Mordini: 1929, prancha 4.

Já as outras características, como cenho, nariz e boca são mais varáveis, mas, no geral, são sugeridos entre as linhas dos membros do sauro. Na tanga ilustrada na figura 94c, por exemplo, o nariz é sugerido por meio da reflexão dos membros a partir de quadrantes separados, criando uma figura retangular, já nas 
outras duas tangas ilustradas nas figuras 94 a e $94 \mathrm{~b}$ o nariz é sempre sugerido no painel superior, abaixo dos olhos, por meio da oposição dos membros do sauro. A boca pode, às vezes, ser sugerida, em ambos os casos, pelo tronco losangular do sauro, no entanto, é mais comum que seja sugerida pelas linhas horizontais que unem os troncos losangulares que se localizam na parte inferior.

Em alguns casos específicos relacionados à variante "b", ou seja, aquela estruturada em quadrantes, os olhos se localizam quase fora do campo da visão, com o nariz composto pelo tronco do sauro localizado entre os olhos (figura 95a). Uma tanga da antiga coleção Barbie Mueller (figura 95b), curiosamente, apresenta motivos estruturados semelhantemente e ordenados da mesma maneira, no entanto, o seu layout é caracterizado por painéis verticais. Nota-se, nesta tanga, que o motivo losangular alude a um ser serpentilíneo enrolado sobre um fundo cruciforme vermelho, de maneira semelhante às figuras do sauro estruturadas nos quadrantes destas tangas onde os membros dos sauros, projetados flexionados para fora, sugerem uma figura cruciforme sob o seu tronco losangular.
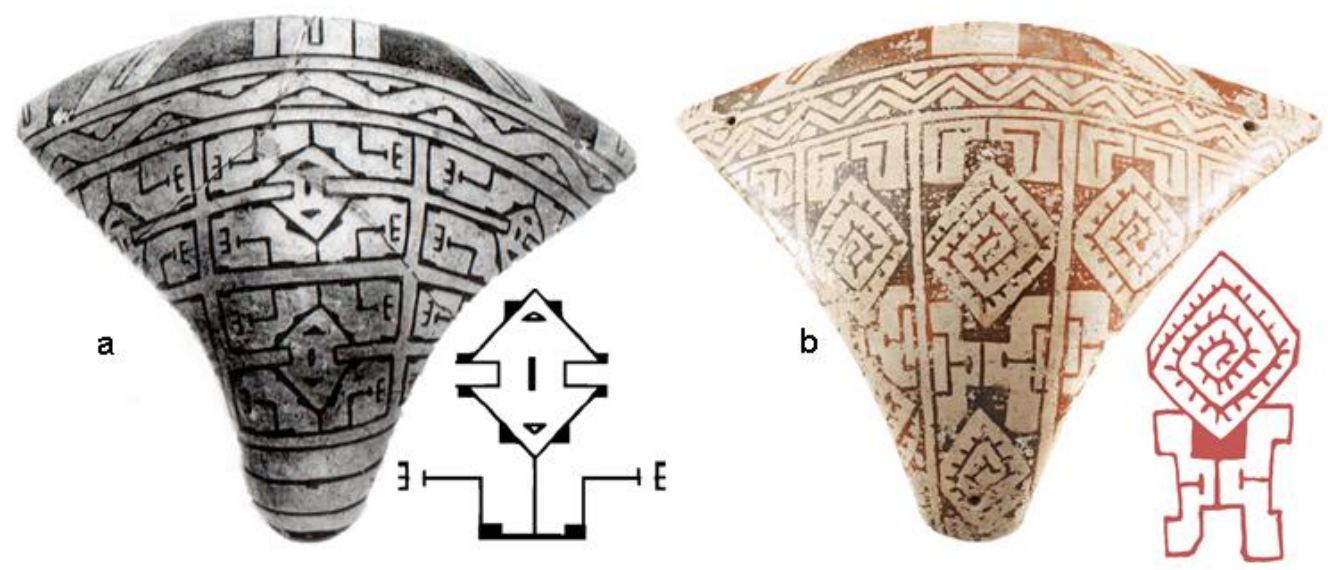

Figura 95. Imagens semelhantes compostas por motivos e estruturas diferentes e que escondem figuras antropomorfas.

a. National Museum of American Indian. Fonte: Nordenskiöld, 1930, prancha XVI.

b. Antiga Coleção Barbier Mueller. Fonte: sothebys.com

Como se pode observar, as tangas deste grupo possuem características bem particulares para capturar a visão e fazê-la se transformar constantemente. Motivos aludindo à figura do sauro são estruturados para sugerir uma face, no entanto, nem todos os atributos desta face são mostrados diretamente, o olhar deve enquadrar a 
figura para perceber que é na relação entre as suas partes que boca e nariz são sugeridos. Além disto, como se vê na ilustração acima, a imagem pode constantemente agenciar o olhar na percepção de novas figuras e, com isto, a figura do sauro pode se transformar, dependendo de como é vista, revelando uma figura antropomorfa (figura 95a) ou ainda, como se vê na figura 95b, seres podem ser sugeridos entre um motivo e outro.

\subsection{As tangas do grupo 9}

Este grupo abrange um total de 15 tangas cujo padrão do painel gráfico é formado por meio da repetição de um motivo por movimentos simétricos como translação, rotação, reflexão e reflexão deslizante, além de combinações destes, obtendo, assim, um tipo de padrão repetitivo que Shepard (op.cit.) chama de padrão allover (figura 96).

As tangas analisadas deste grupo estão depositadas em três instituições, abrangendo quatro coleções, como visto na tabela abaixo.

\begin{tabular}{|c|c|c|}
\hline & Tangas do grupo 9 \\
\hline Coleção/ Instituição & 2 & $\begin{array}{c}\text { Tesos do Monte Carmelo (1 tanga), } \\
\text { tesos Camuntins e Urubu (1 tanga) }\end{array}$ \\
\hline $\begin{array}{c}\text { ICBS/MAção Dita Acatauassu, Museu } \\
\text { Paraense Emílio Goeldi }\end{array}$ & 2 & Indeterminada \\
\hline Museu Paraense Emílio Goeldi & 2 & Teso Camutins (1 tanga) \\
\hline Museu Nacional & 2 & Indeterminada \\
\hline Museu do Estado de Pernambuco & 1 & Pacoval \\
\hline
\end{tabular}

Também incorporamos neste grupo uma tanga publicada por Young-Sánchez e Schaan (2011) pertencente a uma coleção particular, três tangas da antiga coleção Jean Eugéne Lyon, em Geneva, e uma da Coleção Governo do Estado do Pará, em Belém.

Todas as tangas deste grupo são de morfologia 2 e, destes, cinco apresentam apenas o painel gráfico, como aquelas vistas nas figuras $96 \mathrm{~b}$ e $96 \mathrm{c}$ e, nas outras 
dez, o painel gráfico é composto só pelo painel gráfico e por uma estreita banda 1 , caracterizada pelo padrão 1 do tipo b, como se vê na figura 96a.

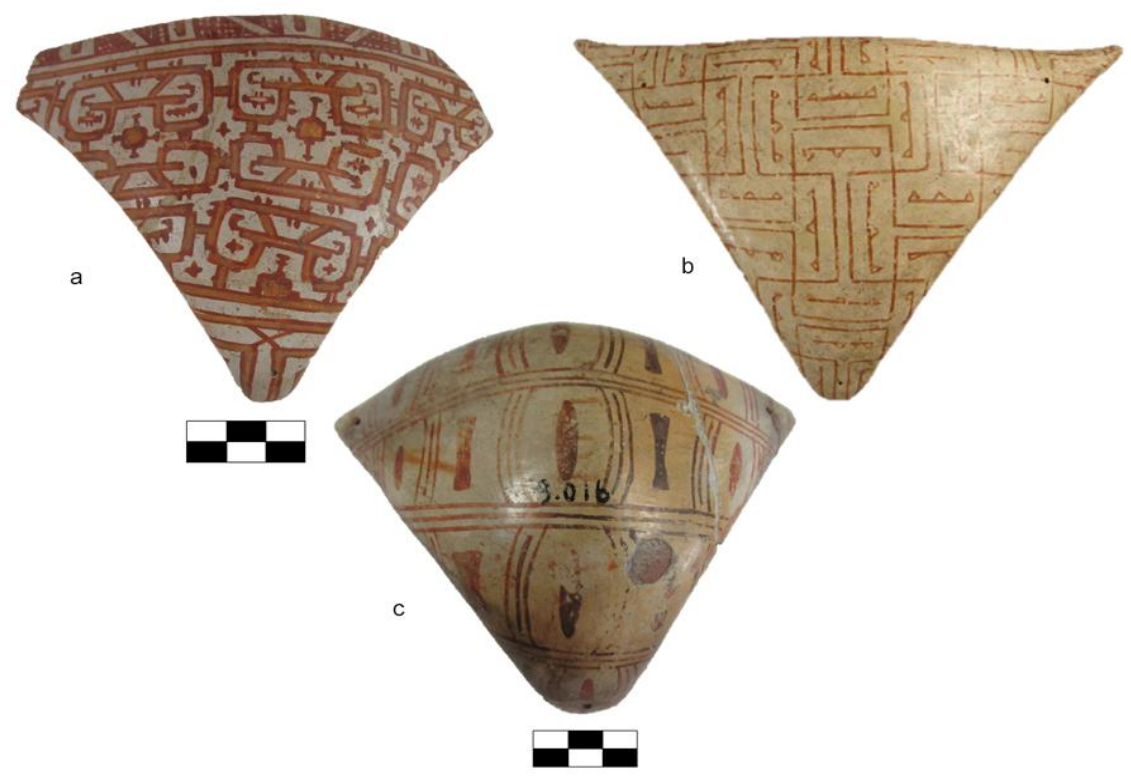

Figura 96. Tangas com painéis gráficos compostos por padrões allover.

a. Coleção ICBS/ MAE-USP, Museu de Arqueologia e Etnologia, São Paulo.

b. Antiga coleção Jean Eugéne Lyon, Geneva. Fonte: zenakruzick.com

c. Museu Nacional, Rio de Janeiro.

Estas se diferenciam de outras devido à forma de estruturar o painel gráfico, que privilegia uma imagem mais "aberta" em relação às imagens vistas em outros grupos. Conforme já comentamos, a imagem vista no painel gráfico é o resultado de um recorte que possibilita enquadrar o olhar em uma parte específica de uma imagem infinita virtual. Por esta razão sugerimos que estas imagens são padrões allover em potencial, já que continuam se repetindo infinitamente em um plano virtual.

As imagens vistas nas tangas deste grupo são estruturadas de acordo com a lógica oposta àquelas. Se em outras tangas o principio da "janela ao infinito" sugere que a imagem continua a se repetir e se transformar fora do campo da visão, aqui, a imagem dada a ver é mais ampla, mostrando mais figuras no plano gráfico.

Apesar de nem sempre o padrão do painel gráfico ser composto por motivos mais "icônicos", como por exemplo, aqueles vistos na figura 96 c e na figura 98, na maioria das vezes, os seus motivos compõem um padrão de rede que permite ver várias figuras escondidas entre uma repetição e outra. $\mathrm{Na}$ tanga ilustrada na figura 
97, por exemplo, ora se vê uma pequena face composta por um motivo que alude ao sauro, ora se vê uma face maior, composta pelo desdobramento desta face menor.

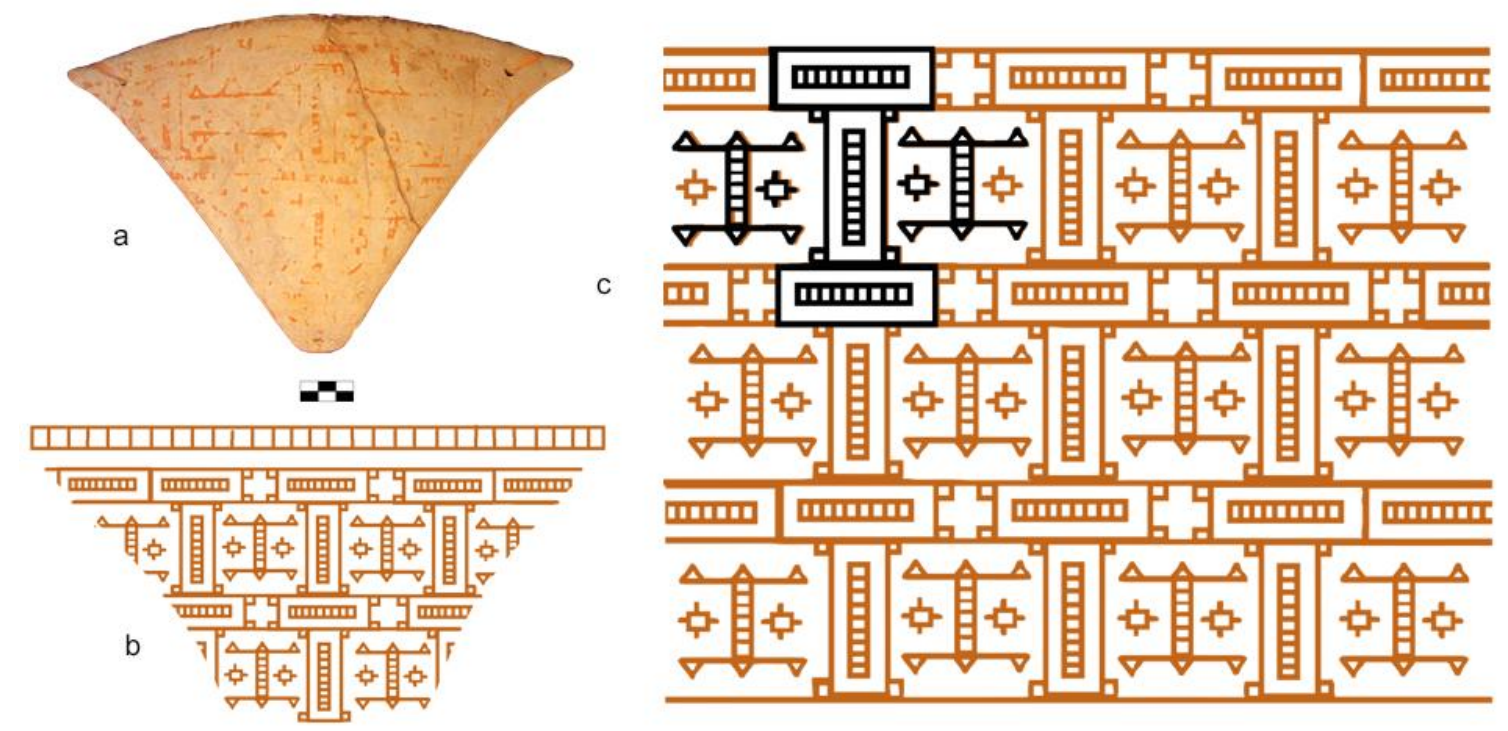

Figura 97. Tanga com padrão composto por várias figuras de faces.

a. Coleção Dita Acatauassu, Museu Paraense Emílio Goeldi, Belém.

b. Reconstituição do padrão da tanga.

c. Rollout com detalhe destacando as figuras vistas no padrão.

Também neste grupo, há quatro tangas e um grande fragmento, todas elaboradas com variantes do mesmo padrão formado a partir da inversão do motivo por meio da rotação no painel gráfico (figura 98). Neste caso, os motivos são simplificações que não mostram figuras explícitas, no entanto, os elementos triangulares e as linhas reticuladas poderiam aludir aos seres que temos visto nas tangas. De todo modo, a inversão do motivo parece ser o mecanismo envolvido na transformação da figura.

É importante destacar que este tipo de simetria só ocorre nestas tangas. Um tipo de estrutura bem semelhante a esta foi observada por Levi-Strauss (2008) na pintura facial Kadiwéu. Ali, os grafismos do rosto eram construídos simetricamente em relação a dois eixos lineares, um vertical acompanhando o plano mediano do rosto, e o outro horizontal que se cruzam na base do nariz e dividem o rosto em quatro setores triangulares opostos, cada um com uma decoração simétrica dupla e se repetidamente invertida no triângulo oposto, conforme já mencionado. 

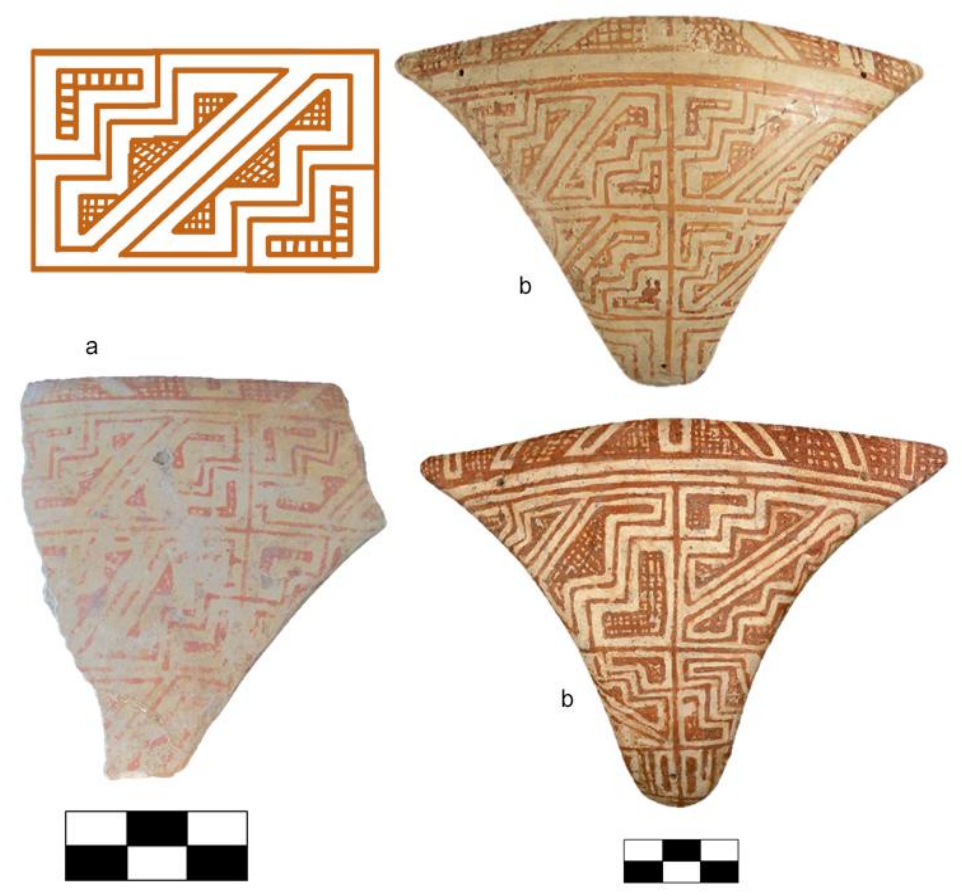

Figura 98. Motivos do painel gráfico invertidos por meio da rotação.

a. Museu Paraense Emílio Goeldi, Belém.

b. Antiga coleção Jeans Eugéne Lyon, Geneva.

c.Coleção ICBS/MAE-USP, Museu de Arqueologia e Etnologia, São Paulo.

Estas tangas, elaboradas por motivos repetidos que compõem um padrão de rede, não por acaso não possuem a banda 2. Anteriormente comentamos que há uma relação de reciprocidade entre os padrões da banda 2 e os padrões do painel gráfico que é caracterizada pelo que é mostrado em cada. Os padrões da banda 2 são compostos por motivos e elementos que se repetem linearmente de modo que para a percepção de certas figuras é necessário enquadrar o olhar em um ponto específico. Já os padrões do painel gráfico, em condições normais, mostram uma imagem que foi recortada ou enquadrada a partir de um padrão que continua a existir virtualmente, de um allover em potencial. Nestas tangas, no entanto, a imagem do painel gráfico é composta semelhantemente aos padrões da banda 2, ou seja, mostram uma imagem elaborada pela repetição e motivos, funcionando do mesmo modo que os padrões da banda 2 . 


\subsection{Os grupos de tangas e a variabilidade regional}

A análise aqui desenvolvida, com base em um grande conjunto, apontou para a variabilidade das tangas. Isto é bastante significativo, já que a maior parte das investigações anteriores, considerando um número limitado de exemplares, apontava para padronização dos seus grafismos por meio da repetição de um número relativamente pequeno de modelos (Meggers e Evans, 1957). Esta variablilidade é produto da combinação e recombinação de um número limitado de motivos aludindo a seres específicos, bem como da transformação destes, por meio de um conjunto de princípios, e é expressa, sobretudo, nos conjuntos de tangas aqui apresentados.

Pontuamos, aqui, novamente, que a classificação das tangas em grupos, como propusemos nesta dissertação, considerou tanto a forma de estruturar os padrões gráficos, quanto a recorrência de certos motivos gráficos, o que, na maioria das vezes, resultou em grupos caracterizados por padrões gráficos formalmente semelhantes. Um aspecto decorrente da classificação das tangas nestes grupos diz respeito à relação destes com sítios específicos, bem como com as regiões do domínio da fase marajoara.

Já nos referimos às limitações do trabalho com coleções museológicas impostas pela falta de contexto e de dados estratigráficos dos objetos. No caso específico das coleções de cerâmica marajoara estas limitações são enormes, sobretudo, decorrentes dos contextos nos quais foram formadas, quando as peças eram coletadas em virtude de suas características estéticas e de conservação.

Há coleções de cerâmica marajoara em diversos museus localizados não somente no Brasil, mas também nos Estados Unidos e em vários países da Europa. Uma parte bastante pequena destas coleções foi formada a partir de escavações sistemáticas, ou seja, poucas delas apresentam documentações das quais é possível extrair não somente procedência, mas também informações referentes aos dados estratigráficos.

Ao longo desta pesquisa, sempre que possível, tentamos obter o máximo de informações não somente a respeito dos processos específicos de formação das coleções pesquisadas, mas também tentamos recuperar o máximo de informações sobre as tangas analisadas, sobretudo, no que diz respeito à sua procedência. A 
preocupação em levantar estas informações pode ser percebida nas tabelas onde detalhamos as coleções e quantidade de peças analisadas de cada grupo em cada instituição, onde, sempre que possível, detalhamos também a procedência das peças.

Tem sido proposto que certos estilos de decoração cerâmica são restritos a determinadas regiões da llha de Marajó, de modo que certas urnas funerárias antropomorfas, decoradas com pintura ou com excisão são mais comuns nos sítios da região do rio Anajás, enquanto aquelas decoradas com incisões sobre engobo branco são muito mais frequentes em sítios localizados a leste do lago Arari, como o Pacoval (Roosevelt, 1991; Schaan, 2007b: 81). Haveria uma tendência semelhante a esta nas tangas, onde temas iconográficos específicos caracterizariam as iconografias de certos sítios ou regiões?

Um aspecto percebido no decorrer desta pesquisa é que a maior parte dos grupos de tangas está presente em vários sítios, marcando presença tanto nos sítios da região do rio Anajás quanto nos sítios da região do lago Arari, ou seja, não parece haver uma correlação entre estes grupos de tangas e sítios específicos ou com regiões de Marajó. Salientamos também que mesmo as tangas que compartilham do mesmo padrão, ou seja, tangas semelhantes, não estão restritas a um sítio ou região específicos. Neste caso, percebemos que muitas tangas provenientes dos sítios do rio Camutins, muitas delas provenientes da Fazenda São Marcos, e distribuídas hoje na coleção ICBS/MAE-USP e também na coleção Governo do Estado do Pará, formam pares com outras tangas provenientes dos sítios do lago Arari, como o teso Pacoval, o teso Severino e o teso Pacoval dos Mello, distribuídas, principalmente, nas coleções do Museu do Estado de Pernambuco (coleção Oliveira), do Museu Paraense Emílio Goeldi (coleção tombada), do Museu Nacional (coleção amazônica) e do Museu de Arqueologia e Etnologia da USP (coleção 006), além de diversas coleções, provenientes dos mesmos sítios, e distribuídas em diversos museus da Europa e dos Estados Unidos, que acessamos por meio de publicações.

As únicas tangas que parecem estar relacionadas a sítios específicos são aquelas do grupo 2. Neste caso, todas as tangas que tiveram a sua procedência identificada são provenientes do conjunto de tesos Os Camutins, e estão distribuídas em três coleções específicas, a coleção ICBS/MAE-USP e a coleção 006, 
depositadas no Museu de Arqueologia e Etnologia da USP, e nas coleções do Governo do Estado do Pará, especificamente a coleção McPhee, que se encontra distribuída no Museu Paraense Emílio Goeldi, no Museu do Forte e no Museu das Gemas, em Belém.

A falta de contextos, bem como de dados estratigráficos destas tangas é um fator que impossibilita compreender de maneira mais ampla as dinâmicas envolvidas na distribuição destes grupos pelos sítios e regiões da ilha de Marajó, assim como os seus possíveis significados. Algumas hipóteses que explicam diferenças regionais entre os estilos poderiam explicar também esta ampla dispersão dos temas e padrões iconográficos pelas diferentes regiões da ilha. Roosevelt (1991), por exemplo, propôs subdividir o período de ocupação de 900 anos referente à fase marajoara em subfases se baseando em possíveis distinções cronológicas e geográficas entre sítios. Em sua pesquisa identificou a subfase Camutins no Rio Anajás, datada entre 400 a 700 A.D. e também a subfase Pacoval a leste do Lago Arari datada entre 700 a 1100 A.D. Escavações posteriores identificou outras duas subfases: a subfase Teso na região do Lago Arari, datada entre 1100 e 1300 A.D. e a subfase Guajará, no rio Anajás, datada entre 700 e 1100 A.D. Conforme é possível observar na tabela abaixo, a subfase Guajará, no rio Anajás, e a subfase Pacoval, no lago Arari, são contemporâneas (Roosevelt, 1991: 399).

\begin{tabular}{|l|l|l|}
\hline \multicolumn{2}{|c|}{ Subfases da fase marajoara identificadas por Roosevelt (1991) } \\
\hline \multirow{2}{*}{ Região } & Subfase & Cronologia \\
\hline \multirow{2}{*}{ Anajás } & Camutins & $400-700$ A.D. \\
\cline { 2 - 3 } & Guajará & $700-1100$ A.D. \\
\cline { 2 - 3 } Lago Arari & Pacoval & $700-1100$ A.D. \\
\cline { 2 - 3 } & Teso & $1100-1300$ A.D. \\
\hline
\end{tabular}

Schaan (2004) propõe subdividir a fase marajoara em períodos, que apesar de definidos com base em critérios diferentes daqueles propostos por Roosevet, concordam, no geral, em relação às cronologias. Propõe subdividir a fase marajoara em quatro períodos tendo como base possíveis processos de mudança cultural: incipiente de 70 a.C. a 400 d.C., expansionista de 400 a 700 d.C., clássico de 700 a 1100 d.C. e declínio de 1100 a 1300 d.C. 


\begin{tabular}{|c|c|}
\hline \multirow{2}{*}{ Períodos da fase marajoara propostos por Schaan (2004) } \\
\hline Período & Cronologia \\
\hline Incipiente & 70 a.C. a 400 d.C. \\
\hline Expansionista & 400 a 700 d.C \\
\hline Clássico & 700 a 1100 d.C \\
\hline Declínio & 1100 a 1300 d.C \\
\hline
\end{tabular}

Conforme pode ser notado, o período entre 700-1100 d.C é coincidente nas duas propostas. Para Schaan (op.cit.) este período teria sido caracterizado pela expansão e ocupação máxima da ilha com os conjuntos de tesos se expandindo por uma área de 20 mil quilômetros quadrados a partir do centro da llha, estabelecendo pequenos cacicados competitivos com estilos cerâmicos distintivos, e dentro disto, o uso de temas iconográficos semelhantes por grupos de parentesco locais, priorizando certos motivos, técnicas de decoração e morfologias cerâmicas (Schaan, 2004).

Diante de um contexto onde não só o estilo, mas também a iconografia são aspectos que diferenciam não apenas regiões e sítios, mas também diferenciariam grupos específicos, por qual razão grupos de tangas, caracterizados pelos mesmos temas iconográficos e, em muitos casos, por padrões gráficos semelhantes, possuem uma dispersão tão ampla? É possível que neste período entre 700 a 1100 d.C. o uso de tangas com os mesmos temas iconográficos e os mesmos padrões tenha se generalizado?

É importante ressaltar que um dos aspectos pontuados no capítulo 3, diz respeito à diferença de frequência entre tangas monocromáticas e tangas com grafismos entre os sítios do rio Anajás e os sítios do lago Arari. Com base em um levantamento, em que foram considerados os registros de escavações em sítios das duas regiões, verificou-se que as tangas com grafismos são mais frequentes nos sítios do lago Arari, enquanto as monocromáticas são mais frequentes nos sítios do rio Anajás.

Os dois tipos são frequentes em sítios das duas regiões, diferindo apenas em frequência. No entanto, é possível que a maior ocorrência de tangas com grafismos nos sítios do lago Arari tenha se dado como um desenvolvimento alcançado com a ocupação dos sítios desta região. Neste sentido, com a ocupação de novas áreas é 
possível que temas iconográficos e padrões gráficos já existentes nos sítios do rio Anajás tenham continuado em uso nos sítios do lago Arari. A ocorrência de tangas com padrões gráficos e morfologias específicas aos sítios do conjunto Os Camutins, como aquelas do grupo 2, poderiam, assim, ser atribuídas a períodos anteriores a esta possível "expansão".

Apesar disto, algumas dúvidas prevalecem. Se entre estas duas regiões as diferenças das cerâmicas marcam estilos regionais, como visto, por exemplo, nas urnas funerárias, por que o mesmo não ocorre com as tangas? Neste sentido, as tangas não parecem ser um marcador de diferenças regionais, mas sim de semelhanças, e assim, caberia a futuras pesquisas, compreender o significado desta semelhança. 


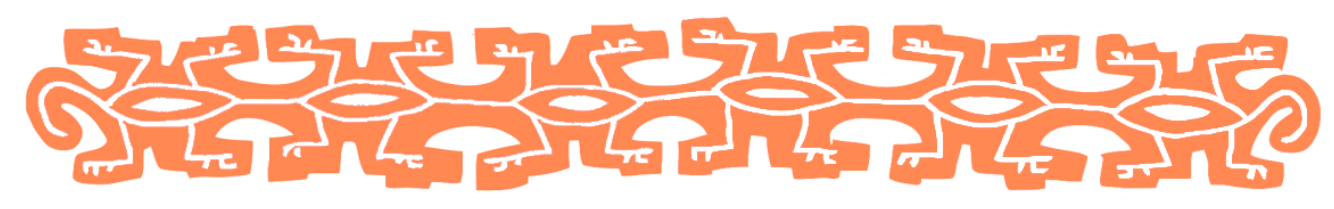

\section{CONSIDERAÇÕES FINAIS}

O estudo de uma categoria específica de objeto, como aqui proposto, permitiu não somente compreender os princípios estruturais que os compõem e também as imagens neles inscritas, mas também permitiu avançar a noção de corporalidade a partir de uma forma específica não apenas de representar corpos, mas também de compor corpos. Neste sentido, o foco na categoria "tanga" possibilitou também uma maior compreensão do regime de figuração marajoara, bem como das formas de materialização de princípios cosmológicos, relacionados à fabricação, à composição e à transformabilidade dos corpos.

Deste modo, o papel das tangas na fabricação e composição de corpos de pessoas deve ser considerado. Trata-se de uma categoria específica de objeto fabricada para ser usada em um corpo, modulando capacidades e qualidade específicas, assim como todos os adornos corporais, no mundo ameríndio. As tangas estão inseridas em um contexto mais amplo relacionado à paramentação dos corpos, abrangendo, além delas, tintas para pintura dos corpos e adornos, como botoques, labretes, contas de colar, etc, o que aponta para importância destes adornos na fabricação dos corpos.

Conforme comentado no capítulo 3, no mundo ameríndio, tintas e grafismos possuem capacidades agentivas distintas que operam performances específicas de acordo com o contexto, conforme sugerido por Lagrou (2007), Müller (2013), Van Velthem $(2003,2013)$. Ali, sugerimos uma possível diferença entre as tangas com grafismos e as tangas monocromáticas em relação aos seus tipos de agentividade. Deste modo, analisamos os grafismos das tangas com vistas a compreender as suas capacidades de encantamento específicas. A análise, que abrangeu todo 0 capítulo 4, identificou princípios e recursos gráficos responsáveis por capturar o olhar e estimular a visão a perceber figuras dentro dos próprios padrões gráficos das tangas, além de figuras virtuais, percebidas com base na abdução da agência. Estes princípios englobam replicações dos motivos gráficos por meio de movimentos 
simétricos e desdobramento, encaixe recurso de figuras, além de recortes e enquadramentos dos padrões gráficos.

A análise iconográfica aqui desenvolvida foi exploratória, com vistas a identificar os principais componentes iconográficos das tangas. Diante disto, percebemos a recorrência de figuras que englobam feições tanto de seres como o jacaré quanto o lagarto, mas que podem também mesclar características antropomorfas, por esta razão denominamos, de "sauro-humano", e também de uma figura serpentelínea com cabeça em forma de pirâmide escalonada de onde são projetadas volutas que poderiam aludir aos barbilhos de certas espécies de peixes, as quais, aqui, foram chamadas de "peixe-serpentelíneo".

Nesta dissertação apenas identificamos estas figuras, sem buscar acessar os seus possíveis conteúdos semânticos. Percebemos, no entanto, como foi comentado no capítulo 4, que existe uma possível relação entre as duas, sendo recorrente a figuração de uma por meio de partes anatômicas da outra. Particularmente, o motivo "pirâmide escalonada", motivo que corresponde à cabeça da figura "peixe-serpentelíneo", pode ser espelhado e, assim, transformado, no motivo "cruz no medalhão", motivo que identificamos como uma possível simplificação da figura do "sauro-humano", ser que quando figurado graficamente, pode ter o seu ventre sugerido por losangos ou por variantes deste motivo, relação que foi, inclusive, observada por Carvalho (1976).

Acreditamos que pesquisas futuras, visando explorar a relação entre estas duas figuras, bem como o seu conteúdo semântico, podem se focar exclusivamente nas cerâmicas do tipo Arari-exciso, onde ocorre a maior incidência de figurações destes dois seres, seja de forma modelada, seja por meio de grafismos excisos, principalmente, nas urnas funerárias deste tipo, onde ocorre a presença simultânea deste dois seres ou de partes suas, sob a forma dos motivos "pirâmide escalonada" e "cruz no medalhão".

\section{Os corpos marajoara}

As imagens materializadas na categoria de artefato estudada nesta dissertação só puderam ser melhor compreendidas por meio de um diálogo com a Etnologia ameríndia e com a Antropologia da Arte. Acreditamos que as iconografias 
dos artefatos provenientes das sociedades da Amazônia antiga podem ser estudadas à luz dos conhecimentos a respeito das sociedades indígenas do presente.

Embora o exercício de explorar objetos arqueológicos à luz destes conhecimentos possa incorrer no risco de se projetar conhecimentos a respeito das cosmologias do presente para interpretar aquelas do passado, ele também pode ser bastante frutífero, considerando-se algumas esferas resistentes da relação entre imagem e identidade nas sociedades ameríndias em geral, o que pode ser crítico na escrita de uma história indígena de longa duração.

Os princípios de construção das imagens, dentro do sistema representacional marajoara, em nosso entender, em muitos aspectos são convergentes com as formas de representação características dos sistemas gráficos ameríndios. Contudo, não podemos negar que no geral a cerâmica marajoara apresenta formas de figuração mais explícitas do que aquelas existentes nos regimes de figuração ameríndios atuais, que conforme certos estudos demonstram, tendem a uma abstração (Lagrou, 2007, 2011; Lagrou e Severi, 2013). Barreto (2009:25) sugere que talvez este figurativismo mais realista que o material pré-colonial, em geral, apresenta esteja relacionado a esferas de reconhecibilidade mais amplas, panamazônicas, enquanto que as imagens mais "abstratas" das sociedades ameríndias atuais talvez reflitam uma circulação mais restrita (e, portanto, mais codifificada), interna ao grupo que as produz.

No entanto, mesmo se corpos e suas partes anatômicas são representados de maneira mais figurativa na arte marajoara, uma característica persistente entre passado e presente é o fato de que os artefatos no universo ameríndio sejam tratados como corpos, alguns deles sendo considerados, inclusive, como partes parceladas de corpos, e mantendo a capacidade agentiva destes (Lagrou e Severi, op.cit:; Silva, 2001; Van Velthem, 203, 2009).

Deste modo, no material marajoara, verificamos uma maneira muito específica não apenas de fabricar corpos, mas também de materializar princípios cosmológicos relacionados à transformabilidade destes corpos, como o constante jogo entre diferentes perspectivas, característico das cosmovisões multinaturalistas amazônicas e da ontologia da predação. 
A composição da imagem a partir de figuras em escalas diferentes, seja por figuras autosimilares, seja por figuras aludindo a seres ou partes do seu corpo, pode estar relacionada a uma fractalidade ameríndia, sobretudo, conforme discutido no capítulo 2, no que diz respeito à constituição do "eu" pela integração do "outro", o que implica em corpos permeáveis à transformação. Ao mesmo tempo, os princípios envolvidos na constituição destas imagens visam estimular a visão de figuras que podem estar escondidas nos emaranhados dos seus grafismos, ou mesmo a figuras que não podem ser percebidas a "olhos nus" dentro do campo da própria imagem, mas que requerem sempre o uso de uma "imaginação perceptiva".

Imagens e estruturas de poder

A forma de materializar certos princípios cosmológicos na fabricação de corpos e imagens, mostrada aqui, traz importantes implicações para se refletir a respeito das estruturas de poder durante a fase marajoara, sobretudo, aquelas que têm sido propostas por Roosevelt (1991) e Schaan (2004). Conforme destacado no primeiro capítulo desta dissertação, a iconografia marajoara foi correlacionada a um processo de transformação de uma sociedade igualitária em uma sociedade hierárquica.

Em um primeiro momento, foi sugerido que o aumento da hierarquização da sociedade refletiu diretamente na iconografia da cerâmica, de modo que as figuras de animais perderam a sua importância no simbolismo xamânico, sendo substituídas por imagens humanas relacionadas aos ancestrais. Aqui, a importância de tais imagens decorreu do seu uso para a sustentação genealógicas das elites ao poder (Roosevelt, 1991). Posteriormente, foi sugerida uma proeminência de figuras relacionadas a serpentes na iconografia marajoara, o que se relacionaria à ligação deste ser com conceitos cosmológicos relacionados ao mito da cobra, usado para justificar a hierarquia social e o acesso diferenciado aos recursos pelas elites (Schaan, 2004).

A análise iconográfica das tangas, aqui apresentada, mostrou que o sistema representacional marajoara não prioriza um tipo específico de figura, seja ela antropomorfa ou zoomorfa, mas ao contrário, engloba componentes gráficos que aludem tanto a seres antropomorfos quanto seres zoomorfos. As imagens 
compostas nas tangas, especificamente, mostram faces que são compostas por corpos e partes anatômicas de animais. Neste sentido, o conjunto de imagens analisadas não foge à regra de composição dos corpos marajoara materializados, por exemplo, em urnas funerárias e estatuetas, que representam figuras antropomorfas que possuem as suas partes anatômicas sugeridas por corpos de animais.

Deste modo, percebe-se que o regime de figuração marajoara concebe corpos compósitos, o que é proeminente, sobretudo, na iconografia das tangas, o que é análogo às formas de concepção de corpos e pessoas nas ontologias construtivistas ameríndias, que conforme comentado no capítulo 2 , concebem os seres como entidades feitas de corpos e partes de corpos de uma miríade de outros seres (Santos-Granero, 2012).

A maneira de conceber os corpos que é priorizada no regime de figuração marajoara está de acordo com o que é visto na Amazônia multinaturalista, onde natureza e cultura fazem parte de um mesmo campo sociocósmico (Viveiros de Castro, 2002: 370). Aqui, a instabilidade das formas de representação dos corpos, com figuras híbridas de humanos e animais, é característica do mundo altamente transformacional das culturas amazônicas que ilustram de maneira visual a noção do corpo como lugar para constantes transformações (Barreto, 2009:51).

Neste sentido, as imagens nas tangas mostram corpos em transformação, compostos por meio de uma amálgama de seres. Estas formas de representação poderiam estar relacionadas à importância do xamanismo no Marajó antigo. Neste sentido, o simbolismo xamânico envolvendo tais transformações corporais poderia destacar a capacidade xamânica de tomar as mais distintas perspectivas e mesmo enfatizando capacidades de acessar outros mundos, conforme alguns estudos iconográficos de materiais arqueológicos têm sugerido (Barreto, op.cit:; Oliveira, 2016; Reichel-Dolmatoff, 1990).

Os princípios formais que estas imagens englobam dialogam com aquilo que Lagrou (2011) chama de uma "arte das sociedades contra o Estado", caracterizada, sobretudo, por procedimentos que permitem ao espectador mudar de ponto de vista, ou perspectiva, e pela integração construtiva e dosada de agências inimigas e predatórias, o que nos grafismos, poderia ser percebido, principalmente, no movimento transformativo entre corpos e no caráter compósito dos seres. 
Como forma de questionar certas ideias segundo as quais "as sociedades humanas percorreram um caminho de crescente complexificação e que, a partir de pequenas aldeias relativamente autônomas, tornaram-se sociedades regionais (cacicados, entre elas) e então estados" (Schaan, 2010:50), o perspectivismo e a ontologia da predação têm sido correlacionados à ideia de que, nas terras baixas, as sociedades ameríndias podem se organizar em comunidades mais autônomas do ponto de vista político e econômico, mantendo tal autonomia ou por meio da perpetuação de um estado de guerra, ou pela participação em extensas redes de relações com os vizinhos, sendo que o xamanismo é um elemento essencial nesta dinâmica (Clastres, 2004; Figueireido, 2006; Sztutman, 2005, 2013; Viveiros de Castro, 2002, Gallois, 2005).

O trânsito cósmico, característico da cosmovisão perspectivista, responsável por tornar as identidades pessoais e coletivas sempre instáveis no mundo ameríndio, seria um impedimento para a centralização do poder político, que só poderia se constituir sobre uma unidade identitária estável, não ameaçada por mudanças de perspectiva advindas da incorporação de subjetividades diversas (Sztutman, 2005:79). Já a predação implica na incorporação contínua das diferenças, ameaçando, deste modo, a centralização de poder ao impor um movimento incessante de buscar a matéria para a sociabilidade e impedir a estabilização de uma interioridade e de uma identidade coletiva dos grupos (Figueiredo, 2006).

Deste modo, entendemos que a iconografia das tangas cerâmicas expressa noções mais relacionadas à fabricação dos corpos e princípios cosmológicos referentes à mediação entre diferentes perspectivas, entre o visível e o invisível do que estratégias ideológicas visando a legitimação do poder de certos grupos sociais, como aquelas apresentadas no capítulo 1.

Nesta dissertação tentamos demonstrar o potencial existente nas coleções de objetos contidas nas reservas técnicas dos museus, que na maioria das vezes, são desprezadas por que não possuem os seus contextos registrados. Esperamos ter demonstrado, assim, a importância destes objetos para os estudos iconográficos, assim como da importância destes estudos para a compreensão das maneiras 
específicas que as sociedades pretéritas concebem, estruturam e representam os seus universos e os princípios cosmológicos que estruturam estes universos. 


\section{BIBLIOGRAFIA}

AMORIM, LILIAM B. 2010. Cerâmica marajoara. A comunicação do silêncio. Belém: Museu Paraense Emílio Goeldi.

ARCURI, MÁRCIA. 2007. Tribos, Cacicados ou Estados? A dualidade e centralização da chefia na organização social da América pré-colombiana. Revista do Museu de Arqueologia e Etnologia, São Paulo, 17: 305-320.

BARATA, FREDERICO. 1968. Artes plásticas no Brasil: Arqueologia. Edições de ouro, Rio de Janeiro.

BARRETO, CRISTIANA.

2004. Simbolismo sexual na antiga Amazônia. Revisitando urnas, estatuetas e tangas marajoara. In: Antes: histórias da pré-história. Catálogo de exposição. Rio de Janeiro: Centro Cultural Banco do Brasil.

2009. Meios místicos de reprodução social: arte e estilo na cerâmica funerária da Amazônia antiga. São Paulo: Programa de pós-graduação em Arqueologia. Museu de Arqueologia e Etnologia. Universidade de São Paulo (Tese de Doutorado).

2014. Modos de figurar o corpo na Amazônia précolonial. In: Stéphen Rostain. (Org.). Antes de Orellana. Actas del 3er Encuentro Internacional de Arqueología Amazónica. 1ed.Quito: Instituto Francés de Estudios Andinos, v. 1, p. 123-132.

2017. Figurine traditions of the Amazon. In: Timothy Insoll (org.).

Oxford Handbook of Prehistoric Figurines. Oxford: Oxford University Press.

BARRETO, C., LIMA, H. P., BETANCOURT, C. J. 2016. Cerâmicas Arqueológicas da Amazônia: rumo a uma nova síntese. Belém: IPHAN /Museu Paraense Emílio Goeldi. 
BARROS, EDIR P. 2003. Os filhos do sol: história e cosmologia na organização social de um povo karib: os kura-bakairi. São Paulo: Editora da Universidade de São Paulo.

PAIS DE BRITO, JOAQUIM. 2000. Os índios, Nós. Lisboa: Museu Nacional de Etnologia.

BROTHERSTON, G. 1997. La América indígena en su literatura: los libros del quarto mundo. México, D.F: Fondo de Cultura Económica.

CARNEIRO, ROBERT.

.1970. A Theory of the Origin of the State. Science, 169:733-738. 1981.The Chiefdom: Precursor of the State. In Grant D. Jones and Robert R. Kautz (org.). The Transition to Statehood in the New World, pp, 3779. Cambridge: Cambridge University Press. 2007. A base ecológica dos cacicados amazônicos. Revista de Arqueologia, 20: 117-154

CARVALHO, SILVIA. M.S. 1976. O duplo jacaré (a cerâmica marajoara). Revista de Ciências Sociais. UNESP, vol.1.

CHILD, V. G. 1983. Man makes himself, New York: Meridian.

CORREA, C. G.; BARRY, I. 2002. Amazonie précolombienne dans les collections du Museo Barbier-Mueller de Arte Precolombino, Barcelona. Barcelona \& Genéve: 5 Continents, Museo Barbier-Mueller de Arte Precolombino, Musée Barbier-Mueller.

COVARRUBIAS, MIGUEL. 1961. El águila, el jaguar y la serpiente. Arte indígena americano: América del Norte: Alaska, Canadá, los Estados Unidos. México, D.F.: Universidad Nacional Autónoma de México. 
DEMARCHI, A. 2009. Armadilhas, quimeras e caminhos: três abordagens da arte na antropologia contemporânea. Espaço Ameríndio, Porto Alegre, v. 3, n. 2, p. 177199, jul./dez.

DE PAULA, CAMILA G. 2015. Num mundo de muitos corpos: um estudo sobre objetos e vestimentas entre os Wajãpi no Amapá. Dissertação de mestrado. São Paulo: Programa de Pós-Graduação em Antropologia Social. Faculdade de Filosofia, Letras e Ciências Humanas. Universidade de São Paulo.

EARLE, TIMOTHY.

.1990. Style and Iconography as Legitimation in Complex Chiefdoms. In by M. Conkey and C. Hastorf, The Uses of Style in Archaeology, Cambridge: Cambridge University Press, pp. 73-81.

1991a. Chiefdoms: Power, Economy, and Ideology. School of American Research Advanced Seminar Series. Cambridge: Cambridge University Press.

.1991b. The Evolution of Chiefdoms. In Thimoty Earle, Chiefdoms:

Power, Economy and Ideology. Cambridge: Cambridge University Press, pp. 1-15.

FAUSTO, CARLOS.

2013. "A máscara do animista: quimeras e bonecas russas na América indígena". In: Carlo Severi \& Els Lagrou, Quimeras em diálogo: grafismo e figuração na arte indígena. Rio de Janeiro: 7Letras. pp. 305- 331

.2005. Os índios antes do Brasil. 3. ed. Rio de Janeiro: Jorge Zahar.

FERREIRA PENNA, D. S. 1877. Apontamentos sobre os Cerâmios do Pará. Archivos do Museu Nacional do Rio de Janeiro, 2 , 47-67.

FREEDBERG, DAVID.1992. El poder de las imágenes, estudios sobre la historia y la teoría de la respuesta. Madrid: Ediciones Cátedra, S.A. 
FIGUEIREDO, MARINA VANZOLINI. 2006. Centralização e faccionalismo: imagens da política no alto Xingu. Dissertação de mestrado. Rio de Janeiro: Museu Nacional/UFRJ.

FIGUEIREDO, NAPOLEÃO. 1956. Arte amazônica, IV: As "tangas" do Marajó. São Paulo: Habitat, ํo30.

FIGUEIREDO, N.; FOLHA, M. H. DE AMORIM. 1976. Catálogo ilustrado da coleção arqueológica. Maceió: Instituto Histórico e geográfico de Alagoas.

GALLOIS, DOMINIQUE TILKIN (Org.). 2005. Redes de relações nas Guianas. São Paulo: Associação Editorial Humanitas: FAPESP.

GELL, ALFRED.

.1992. The technology of enchantment and the enchantment of technology". In Coote and Shelton (eds.). Anthropology, Art and Aesthetics. pp. 40-63.

. 1995. "On Coote's 'Marvels of everyday vision"'. In J. F. WEINER (org.). Too many meanings: a critique of the anthropology of aesthetics. Social Analysis, $\mathrm{n}^{\circ} 38$, pp.18-31.

.1998. Art and agency. An anthropological theory. Oxford: Clarendon Press.

GILlESPIE, SUSAN D. 1993. Power, Pathways, and Appropriations in Mesoamerican Art. In: Whitten, Dorothea S. e Whitten, Norman E. (orgs.) Imagery and Creativity: Ethnoaesthetics and Art Worlds in the Americas. Tucson: University of Arizona Press, pp. 67-107.

GÖLTE, J. 2009. Moche, Cosmología y Sociedad: una interpretación iconográfica. Cusco: Instituto de Estudios Peruanos. 
GOMES, D. M. C.

.2002. Cerâmica arqueológica da Amazônia: vasilhas da Coleção

Tapajônica MAE-USP. São Paulo: FAPESP/EDUSP/ Imprensa Oficial de São Paulo.

.2012. O Perspectivismo Ameríndio e a Ideia de uma Estética Americana. Boletim do Museu Paraense Emílio Goeldi. Ciências Humanas, 7 (1): 133-159.

.2014. Imágenes de las sociedades contra el Estado en la Amazonia

Antigua. In: Campagno, Marcelo (org), Pierre Clastres y las Sociedades Antiguas.

Buenos Aires: Miño y Dávila, pp. 81-98.

2016. O lugar dos grafismos e das representações na arte pré-colonial amazônica. Mana 22(3): 671-703.

GOSDEN, Chris. What do objects want? Journal of Archaeological Method and Theory, Vol. 12, No. 3, September 2005, pp. 193-211.

HARTT, C. F. 1871.

The Ancient Indian Pottery of Marajo, Brazil. American Naturalist, 5 (5), 259-271.

1876. Notas sobre algumas Tangas de Barro Cozido dos Antigos Indígenas da llha de Marajó. Archivos do Museu Nacional do Rio de Janeiro.

1885. Contribuições para a Ethnologia do Valle do Amazonas.

Archivos do Museu Nacional do Rio de Janeiro, v. 6, p. 1-174.

HEGMON, Michelle.1992. Archaeological research on Style. Annual Review of Anthropology, Vol. 21, 517-536.

HILBERT, P. PAUL. 1952. Contribuição à arqueologia da ilha de Marajó os "tesos" marajoaras do alto Camutins e a atual situação da ilha do Pacoval, no Arari. Belém: Instituto de Antropologia e Etnologia do Pará, Instituto de Antropologia e Etnologia do Pará. Publicação, 5. 
HILL, J. 2012. Materializando lo oculto: um acercamiento a la compreensión de la naturaliza de la materialida em la ontologia wakuénai. In: Santos-Granero, Fernando (org.). La vida oculta de las cosas: Teorías indígenas de la materialidad y la personeidad. Quito: Abya-Yala.

HODDER, I. 1985. Post-processual archaeology. In: Schiffer, M (ed.) Advances in Archaeological Method and Theory, Vol. 8. New York: Academic Press:1-26.

ILLIUS, B. 1995. La "Gran Boa", Arte y Cosmología de los Shipibo-Conibo, in: Bulletin de la Société Suisse des Américanistes 55/56 (1995), S. 23-35.

INGOLD, T.1996. Key debates in anthropology. Londres/ Nova York: Routledge

LAGROU, E. \& SEVERI, C. (Orgs.). Quimeras em diálogo: grafismo e figuração nas artes indígenas. Rio de Janeiro: 7Letras.

LAGROU, E.

2007. A Fluidez da Forma. Arte, alteridade e agência em uma sociedade amazônica (Kaxinawa, Acre). Rio de Janeiro: Topbooks.

2011. Existiria uma arte das sociedades contra o Estado? Revista de Antropologia, v. 54, n. 2, p. 747-780. Universidade de São Paulo - USP, São Paulo.

.2012. La memória cristalizada de los artefatos: uma reflexión sobre la agencia y la alteridade en construcción de imágenes entre los Cashiahua. . In: Santos-Granero, Fernando (org.). La vida oculta de las cosas: Teorías indígenas de la materialidad y la personeidad. Quito: Abya-Yala.

.2013. "Podem os grafismos ameríndios ser considerados quimeras abstratas? Uma reflexão sobre um a arte perspectivista. In: LAGROU, E. \& SEVERI, C. (Orgs.). Quimeras em diálogo: grafismo e figuração nas artes indígenas. Rio de Janeiro: 7Letras.

LANGE, ALGOT. 1914. The Lower Amazon. New York: Putnam. 
LAU, GEORGE F.

2010. The work of surfaces: object worlds and techniques of enhancement in the ancient Andes. Journal of Material Culture. 15(3), 259-286.

2011. Andean expressions: art and archaeology of the Recuay culture. lowa City: University of lowa Press.

LÉVI-STRAUSS, CLAUDE. 2008 (1958). Antropologia Estrutural. São Paulo: Cosac Naify.

LIMA,T.A. 2005. Vestígios de uma cultura. Revista Ciência Hoje. Instituto Ciência Hoje, n.36, 30-33, Março.

MAUSS, MARCEL. 2003. Ensaio sobre a Dádiva. São Paulo: Cosac Naify.

MEGGERS, BETTY J.; EVANS, C. 1957. Archaeological Investigations at the Mouth of the Amazon. Bureau of American Ethnology, Bulletin 167. Smithsonian Institution Press.

MEGGERS, BETTY J.

.1947. The Beal-Steere collection of pottery from Marajó Island, Brazil.

Papers of the Michigan Academy of Science, Arts and Letters, Vol. XXXI. .1954. Uma interpretação das culturas da llha de Marajó. Belém, Pará, Brasil: Instituto de Antropologia e Etnologia do Pará .1977 [1971]. Amazônia: a llusão de um paraíso. Rio de Janeiro: Civilização Brasileira.

MILLER, JOANA.

.2007. As coisas: enfeites corporais e a noção de pessoa entre os Mamaindê (Nambiquara). Tese de Doutorado, PPGAS-Museu Nacional, UFRJ. .2012. Las cosas como personas: adornos corporales y alteridade entre los Mamaindê (Nambicuara). In: Santos-Granero, Fernando (org.). La vida oculta de las cosas: Teorías indígenas de la materialidad y la personeidad. Quito: AbyaYala. 
MORDINI, ANTONIO. 1929. I 'couvre sexe' precolombiani in argilla dell'isola de Marajó. Firenze: Archivio per l'Antropologia e l'Etnologia, v.59, pp.41-46.

MORPHY, H. (1994). "The anthropology of art". T. INGOLD (org.), Companion encyclopedia of anthropology. Londres/Nova York: Routledge, 648-85.

MÜLLER, REGINA POLO.

1990. Os Asuriní do Xingu, História e Arte. Campinas: Editora da Universidade Estadual de Campinas.

1992. Tayngava, a noção de representação na arte gráfica. In: Vidal, L.B. (Org). Grafismo indígena. São Paulo: Studio Nobel/ FAPESP/EDUSP, pp.231248.

MUNN, NANCY.

1973. Walbiri Iconography, Graphic Representation and Cultural

Symbolism in a Central Australian Society. Ithaca: Cornell University Press. . 1977. The Spatiotemporal Transformations of Gawa Canoes. Journal de la Société des océanistes, Année, Volume 33 Numéro 54 pp. 39-53.

NIETZEL, J. E. 1995. Elite styles in hierarchically organized societies: the chacoan regional sistem. In: CARR, C. \& NEITZEL, J. E. (eds.). Style, Society and Person (Archaeological and Ethnological Perspectives). New York/London: Plenum Press, pp 393-418.

NETO, A. BARCELOS

. 2012. La (des)animalización de los objetos: ofrendas de comida y subjetivación de máscaras y flautas entre los Waujá. In: Santos-Granero, Fernando (org.). La vida oculta de las cosas: Teorías indígenas de la materialidad y la personeidad. Quito: Abya-Yala.

.2006. De divinações xamânicas e acusações de feitiçaria: imagens Wauja da agência letal. Mana 12(2): 285-313.

2008a. Apapaatai Rituais de Máscaras no Alto Xingu. São Paulo: Edusp. 
.2008b. Choses (in)visibles et (im)périssables. Temporalité et matérialité des objets rituels dans les Andes et en Amazonie. Gradhiva, no.8, n.s.

NETTO, LADISLAU. 1885. Investigações sobre a archeologia brazileira. Rio de Janeiro: Archivos do Museu Nacional do Rio de Janeiro, vol.6, pp. 257-554.

NEVES, E.G.

1999. O Velho e o Novo na Arqueologia Amazônica. Revista USP, São Paulo, v. 44, p. 87-113.

. 2006. Arqueologia da Amazônia. Rio de Janeiro: Jorge Zahar Editor. .2008. Ecology, Ceramic Chronology and Distribution, Long-term History, and Political Change in the Amazonian Floodplain. In Helaine Silverman e William Isbell (org). Handbook of South American Archaeology, Springer, Nova York, pp. 359-379.

NOBRE, EMERSON. 2016. Resenha: Severi, Carlo; Lagrou, Els. "Quimeras em diálogo. Grafismo e figuração na arte indígena". Goiânia: Habitus, v. 14, n.1, p. 157162, jan./jun.

NORDENSKIÖLD, ERLAND.1930. L'Archeologie du Bassin de l'Amazone. Ars Americana, vol.1. Paris.

OLIVEIRA, ERÊNDIRA. 2016. Potes que encantam: estilo e agência na cerâmica polícroma da Amazônia central. Dissertação de mestrado. São Paulo: Programa de pós-graduação em Arqueologia. Museu de Arqueologia e Etnologia. Universidade de São Paulo.

OSBORNE, ROBIN. 2007. Sex, Agency, and History: The Case of Athenian Painted Pottery. In Osborne, R. e Tanner, J. (org.). Art's agency and art history. Oxford: Blackwell Publishig Ltd, p.p. 135-157. 
PALMATARY, H.C.

1950. The pottery of Marajo Island, Brazil. Philadelphia:

Transactions of the American Philosophical Society 39 (3).

1960. The archaeology of the Lower Tapajós Valley, Brazil.

Philadelphia: Transactions of the American Philosophical Society, 50(3):1-246

POZORSKI, S. e POZORSKI, T. 2011. The square-room unit as an emblem of Power and authority within the initial period Sechín Alto polity, Casma Valley, Peru. Latin American Antiquity, v. 22, n. 4, p. 427-548

PROUS, A.; LIMA, A.P. 2011. De Cobras e Lagartos: as tangas marajoaras. Revista do Museu Arqueologia e Etnologia, São Paulo, n. 21, p. 231-263.

PROUS, A. 2013. Tangas of the Marajó (Brazil): ornamental pubic covers, their typology and meaning. Antiquity, Vol. 87, Issue 337, p.815.

QUILTER, JEFREY. 2007. Representational Art in Anciet Peru and the work of Alfred Gell. In Osborne, R. e Tanner, J. (org.). Art's agency and art history. Blackwell Publishig Ltd, Oxford, p.p. 135-157.

REICHEL-DOLMATOFF, GERARDO. 1990. Orfevreria y Shamanismo: Un estudio iconográfico del Museo del Oro. Medellin: Editorial Collina.

RODRIGUES, IGOR et al. 2011. Fabricação e utilização experimentais de réplicas de tangas marajoara. Revista do Museu Arqueologia e Etnologia, São Paulo, n. 21 , p. 265-274.

ROOSEVELT, ANNA C.

1987. Chiefdoms in the Amazon and Orinoco. In: Drennan, R. D. e Uribe, C. (orgs.). Chiefdoms in the Americas. Lanham: University Press of America, p. 153-184. 
1988. Interpreting Certain Female Images in Prehistoric Art. In: Miller,

V. (org). The Role of Gender in Precolumbian Art and Architecture. Harvard: University Press, p.1-34.

1991. Moundbuilders of the Amazon: Geophysical Archaeology on Marajo Island, Brazil. San Diego: Academic Press.

1992. Arqueologia Amazônica. In: Carneiro da Cunha, Manuela (org.). História dos Índios no Brasil. São Paulo: Companhia das Letras, pp. 5386.

1993. The Rise and Fall of the Amazonian Chiefdoms. L'Homme, 126-128, XXXIII (2-4).

SANTOS-GRANERO, FERNANDO. 2012. Introducción. In: Santos-Granero, Fernando (org.). La vida oculta de las cosas: Teorías indígenas de la materialidad y la personeidad. Quito: Abya-Yala, pp.13-43.

SCATAMACCHIA, M. C. M. et al. 1991. Aproveitamento científico de coleções museológicas: proposta para classificação de vasilhas da tradição Tupiguarani. Clio, UFPE, 4: 89-94.

SCHAAN, DENISE. P.

1996. A Linguagem Iconográfica da Cerâmica Marajoara. Dissertação (Mestrado em História - Área de Concentração Arqueologia). Porto Alegre: Universidade Católica do Rio Grande do Sul, 1996.

1997. A linguagem iconográfica da cerâmica marajoara: um estudo da arte pré-histórica da llha de Marajó, Brasil (400-1300 AD). Porto Alegre: Edipuc/RS.

2001. into the labyrinths of Marajoara pottery: status and cultural identity in an Amazonian complex society. In: MCEWAN, C et al (orgs.). The Unknown Amazon. Nature in culture in ancient Brazil, pp. 108-133. Londres: British Museum Press.

2001b. Estatuetas antropomorfas marajoara: o simbolismo de identidades de gênero em uma sociedade complexa amazônica. Boletim do Museu Paraense Emílio Goeldi. série Antropologia, 17(2). 
2003. A ceramista, seu pote e sua tanga: identidade e papéis sociais em um Cacicado Marajoara. Revista Arqueologia, 16: 31-45.

2004. The Camutins Chiefdom: Rise and Development of Social Complexity on Marajó Island, Brazilian Amazon. Tese de doutorado. Pittsburg: Universidade de Pittsburgh.

2007a. Os Filhos da Serpente: Rito, Mito e Subsistência nos Cacicados da Ilha de Marajó. Inter. J. South American Archaeology, pp.50-56.

2007b. Uma janela para a pré-história colonial: olhando além- e apesar- das fases e tradições. Belém: Boletim do Museu Paraense Emílio Goeldi. Ciências Humanas, v.2, n.1, pp.77-89.

2009. Cultura Marajoara. Rio de Janeiro: Senac Nacional.

2010. Sobre os cacicados Amazônicos: sua vida breve e sua morte anunciada. Jangwa Pana, [S.I.], v. 9, n. 1, p. $45-64$.

SCHAAN, D. P.; SILVA, WAGER F.V. 2004. O Povo das Águas e sua Expansão Territorial: uma Abordagem Regional de Sociedades Pré-Coloniais na ilha de Marajó. Revista de Arqueologia, v. 17, p. 13-32.

SHANKS, M. 2008: 1133-144. Post-processual archaeology and after. In: BENTLEY, R.A.; MASCHNER, H. D. G. e CHIPPINDALE, C. Handbook of Archaeological Theories . Lanham, MD: AltaMira Press.

SEEGER, ANTHONY. 1980. Os Índios e Nós: Estudos sobre Sociedades Tribais Brasileiras. Rio de Janeiro: Editora Campus. pp. 43-60.

SEEGER, ANTHONY et al. 1979. A construção da pessoa nas sociedades indígenas brasileiras. Boletim do Museu Nacional, Série Antropologia, 32:2-19.

SEVERI, CARLOS. 2013. O espaço quimérico. Percepção e projeção nos atos do olhar. In: LAGROU, ELS e SEVERI, CARLO (orgs).Quimeras em diálogo: grafismo e figuração nas artes indígenas. Rio de Janeiro: 7Letras. 
SHANKS, M e TILLEY, C. 1992. Reconstructing archaeology: theory and practice. Cambridge, Cambridge University Press.

SHEPARD, A. O. 1965. Ceramics for the Archaeologist. Washington: Carnegie Institution of Washington publication; 609.

SILVA, F. 2000. As Tecnologias e Seus Significados: Um estudo da cerâmica dos Asurini do Xingu e da cestaria dos Kayapó-Xikrin sob uma perspectiva Etnoarqueológica. Tese (Doutorado em Arqueologia). São Paulo: Museu de Arqueologia e Etnologia, Universidade de São Paulo.

STEWARD, J.H. (org). 1946-1950. Handbook of South American Indians. Vols. 16. Washington: Smithsonian Institution Press.

STEWARD, J.H. 1948. Culture Areas of the Tropical Forest. In: STEWARD. J.H. (Org). Handbook of South American Indians. Vol. 3, The Tropical Forest Tribes, Bureau of American ethnology Bulletin 143, pp. 883-899.

STEWART, PETER. 2007. Gell's Idols and Roman Cult. In Osborne, R. e Tanner, J. (org.). Art's agency and art history. Oxford: Blackwell Publishig Ltd, p.p. 135-157.

STRATHERN, MARILYN.

2006. O gênero da dádiva. Problemas com as mulheres e problemas com a sociedade na Melanésia. Campinas: Editora da Unicamp. 2013. Learning to see in Melanesia. HAU Masterclass Series, Vol. 2, pp.15-157.

STREIFF, Ruth. 1966. "Catalogue des céramiques du Marajó au Musée d'ethnographie de Genève", in Bulletin de la société suisse des Américanistes, n॰30, pp.31-42.

SZTUTMAN, RENATO. 
2005. O Profeta e o Principal: a ação política ameríndia e seus personagens. Tese de Doutorado, FFLCH, Universidade de São Paulo. 2013. Metamorfoses do Contra-Estado. Ponto Urbe [Online], 13 2013, posto online no dia 31 Dezembro 2013, consultado em 05 de Novembro de 2015. URL : http://pontourbe.revues.org/893 ; DOI : 10.4000/pontourbe.893.

TAYLOR, ANNE-CHRISTINE e VIVEIROS DE CASTRO, EDUARDO. 2006. Un corps fait de regards. In: Stéphane Breton, Qu'est-ce qu'un corps ? Paris, Musée du Quai Branly-Flammarion: 148-199

TORRES, HEloísA A. Arte indígena da Amazônia. Rio de Janeiro: Publicação do Serviço do Patrimônio Histórico e artístico Nacional, n6, Imprensa Nacional, 1940.

TROUFFLARD, J. 2010. Testemunhos funerários da llha de Marajó no Museu Dr. Santos Rocha e no Museu Nacional de Etnologia. Interpretação arqueológica. Dissertação de mestrado. Lisboa: Faculdade de Ciências Sociais e Humanas, Universidade Nova de Lisboa.

TURNER, T.

1980. The social skin. In: Not work alone: A cross-cultural view of activities superfluous to survival, Cherfas, Jeremy; Lewin, Roger (Ed.) 112-140. London: Temple Smith.

2012. Bienes, valor y mercancias entre los Kayapó del Brasil Central. In: Santos-Granero, Fernando (org.). La vida oculta de las cosas: Teorías indígenas de la materialidad y la personeidad. Quito: Abya-Yala.

VAN VELTHEM, L. H.

1995. O Belo É a Fera: A Estética da Produção e da Predação entre os Wayana. São Paulo: Departamento de Antropologia/Universidade de São Paulo (Tese de Doutorado).

2003. O belo é a fera: a estética da produção e da predação entre os Wayana. Lisboa: Museu Nacional de Etnologia: Assírio \& Alvim. 
2009. Mulheres de cera, argila e arumã: princípios criativos e fabricação material entre os Wayana. Mana, 15(1), 213-236.

VIDAL, LUX. 1992. Grafismo indígena. São Paulo: Studio Nobel/ FAPESP/ EDUSP.

VIVEIROS DE CASTRO, E.

. 2002. A inconstância da alma selvagem, e outros ensaios de

antropologia. São Paulo: Cosac \& Naify.

2006. A floresta de cristal. São Paulo: Cadernos de campo, n. 14/15,

p. 319-338.

WAGNER, ROY. 1991. The Fractal Person. In: Strathern, M.; Godelier, M. (Ed.). Big

Men and Great Men: Personifications of Power in Melanesia, pp. 159-173. Cambridge: Cambridge University, Press.

WALLIS, Neill J. 2013. The Materiality of Signs: Enchainment and Animacy in Woodland Southeastern North American Pottery. American Antiquity; 78: 207.

WALKER, H. 2012. Hamacas de bebé y cuencus de piedra: tecnologias urarina de compañerismo y servidumbre. In: Santos-Granero, Fernando (org.). La vida oculta de las cosas: Teorías indígenas de la materialidad y la personeidad. Quito: Abya-Yala, pp.13-43.

WENGROW, DAVID. 2007. Enchantment and Sacrifice in Early Egypt. In Osborne, R. e Tanner, J. (org.). Art's agency and art history. Blackwell Publishig Ltd, Oxford, p.p. $135-157$.

YOUNG-SÁNCHEZ, M.; SCHAAN, D. P. 2011. Marajó. Ancient Ceramics from the Mouth of the Amazon. Denver: Denver Art Museum. 
ANEXOS 


\section{Índice de Anexos}

Anexo 1. Tabela de Levantamento das tangas associadas a sepultamentos. Anexo 2. Ficha de análise. 
ANEXO 1. Levantamento das tangas associadas a sepultamentos. 


\begin{tabular}{|c|c|c|c|c|c|c|}
\hline \multicolumn{7}{|c|}{ LEVANTAMENTO DAS TANGAS ASSOCIADAS A SEPULTAMENTOS } \\
\hline \multirow[b]{2}{*}{ Sítio } & \multirow[b]{2}{*}{ Coletor } & \multicolumn{2}{|c|}{ Tipo de tanga } & \multirow[b]{2}{*}{ Tipo de urna } & \multirow[b]{2}{*}{ Material associado } & \multirow[b]{2}{*}{ Referência } \\
\hline & & $\begin{array}{l}\mathrm{C} / \\
\text { grafismos }\end{array}$ & Monocromática & & & \\
\hline Pacoval & O. Derby & $\mathrm{X}$ & & Pacoval inciso & Ossos humanos & $\begin{array}{l}\text { Hartt, 1876, } \\
1885\end{array}$ \\
\hline Guajará (Monte Carmelo) & Betty Meggers & & $\mathrm{X}$ & Joanes Pintado (urna I) & Ossos humanos & $\begin{array}{l}\text { Meggers e } \\
\text { Evans, } 1957\end{array}$ \\
\hline Guajará (Monte Carmelo) & Betty Meggers & & $\mathrm{X}$ & Joanes Pintado (Urna L) & Ossos humanos & $\begin{array}{l}\text { Meggers e } \\
\text { Evans, } 1957\end{array}$ \\
\hline Guajará (Monte Carmelo) & Betty Meggers & & $\mathrm{X}$ & Inajá simples & Ossos humanos & $\begin{array}{l}\text { Meggers e } \\
\text { Evans, } 1957\end{array}$ \\
\hline Guajará (Monte Carmelo) & Betty Meggers & & $\mathrm{X}$ & $\begin{array}{c}\text { Urna simples, associada } \\
\text { à urna L }\end{array}$ & Ossos humanos & $\begin{array}{l}\text { Meggers e } \\
\text { Evans, } 1957\end{array}$ \\
\hline Guajará (Monte Carmelo) & Betty Meggers & & $\mathrm{X}$ & Inajá simples (urna M) & $\begin{array}{l}\text { Duas tigelas, fragmentos de carvão, } \\
\text { ossos humanos e animais pintados de } \\
\text { vermelho, fragmentos cerâmicos } \\
\text { diversos. }\end{array}$ & $\begin{array}{l}\text { Meggers e } \\
\text { Evans, } 1957\end{array}$ \\
\hline Guajará (Monte Carmelo) & Betty Meggers & & $\mathrm{X}$ & Inajá simples (urna O) & $\begin{array}{l}\text { Uma tigela Joanes pintado, uma tigela } \\
\text { Inajá simples, três outras tigelas } \\
\text { quebradas, ossos desarticulados, } \\
\text { fragmentos diversos. }\end{array}$ & $\begin{array}{l}\text { Meggers e } \\
\text { Evans, } 1957\end{array}$ \\
\hline Guajará (Monte Carmelo) & Betty Meggers & & $\mathrm{X}$ & Associada à urna $\mathrm{O}$ & Fragmentos de ossos humanos & $\begin{array}{l}\text { Meggers e } \\
\text { Evans, } 1957\end{array}$ \\
\hline
\end{tabular}




\begin{tabular}{|c|c|c|c|c|c|c|}
\hline \multirow[b]{2}{*}{ Sítio } & \multirow[b]{2}{*}{ Coletor } & \multicolumn{2}{|c|}{ Tipo de tanga } & \multirow[b]{2}{*}{ Tipo de urna } & \multirow{2}{*}{ Material associado } & \multirow[b]{2}{*}{ Referência } \\
\hline & & $\begin{array}{c}\text { C/ } \\
\text { Grafismos }\end{array}$ & Monocromática & & & \\
\hline Camutins (Os Camutins) & Betty Meggers & & $X$ & Camutins simples & ------ & $\begin{array}{l}\text { Meggers e } \\
\text { Evans, } 1957\end{array}$ \\
\hline Camutins (Os Camutins) & Betty Meggers & & $\mathrm{X}$ & $\begin{array}{l}\text { Joanes Pintado (conjunto } \\
\text { funerário } 1, \text { urna } 1 \text { ) }\end{array}$ & $\begin{array}{l}\text { Terra molhada com manchas de carvão } \\
\text { vegetal e fragmentos cerâmicos } \\
\text { diversos. }\end{array}$ & $\begin{array}{l}\text { Meggers e } \\
\text { Evans, } 1957\end{array}$ \\
\hline Camutins (Os Camutins) & Betty Meggers & $\mathrm{X}$ & & $\begin{array}{l}\text { Joanes Pintado (conjunto } \\
\text { funerário } 1, \text { urna } 4 \text { ) }\end{array}$ & $\begin{array}{l}\text { Fragmentos de osso humanos, pequenos } \\
\text { cacos de vasos, fragmentos de madeira } \\
\text { carbonizada. }\end{array}$ & $\begin{array}{l}\text { Meggers e } \\
\text { Evans, } 1957\end{array}$ \\
\hline $\begin{array}{l}\text { Belém (M17) Os } \\
\text { Camutins }\end{array}$ & Denise Pahl Schaan & & $\mathrm{X}$ & $\begin{array}{c}\text { Joanes Pintado G2 (urna } \\
\text { 4) }\end{array}$ & $\begin{array}{l}\text { Pequenos fragmentos de ossos, manchas } \\
\text { de carvão vegetal, fragmentos. }\end{array}$ & $\begin{array}{l}\text { Schaan, } \\
2004\end{array}$ \\
\hline $\begin{array}{l}\text { Belém (M17) Os } \\
\text { Camutins }\end{array}$ & Denise Pahl Schaan & & $\mathrm{X}$ & $\begin{array}{l}\text { Joanes Pintado G2 (urna } \\
\text { 12) }\end{array}$ & $\begin{array}{l}\text { Solo cinza escuro seco, manchas de } \\
\text { carvão vegetal e fragmentos. }\end{array}$ & $\begin{array}{l}\text { Schaan, } \\
2004\end{array}$ \\
\hline $\begin{array}{l}\text { Belém (M17) Os } \\
\text { Camutins }\end{array}$ & Denise Pahl Schaan & & $\mathrm{X}$ & $\begin{array}{c}\text { Joanes Pintado G1 (Urna } \\
\text { 5) }\end{array}$ & Fragmentos cerâmicos & $\begin{array}{l}\text { Schaan, } \\
2004\end{array}$ \\
\hline $\begin{array}{l}\text { Belém (M17) Os } \\
\text { Camutins }\end{array}$ & Denise Pahl Schaan & & $\mathrm{X}$ & $\begin{array}{c}\text { Joanes Pintado G2 (urna } \\
9 \text { ) }\end{array}$ & ---- & $\begin{array}{l}\text { Schaan, } \\
2004\end{array}$ \\
\hline $\begin{array}{l}\text { Belém (M17) Os } \\
\text { Camutins }\end{array}$ & Denise Pahl Schaan & & $\mathrm{X}$ & $\begin{array}{l}\text { Joanes Pintado G1 (Urna } \\
\text { 15) }\end{array}$ & $\begin{array}{l}\text { Sedimento, ossos, pequenos pedaços de } \\
\text { carvão, fragmentos. }\end{array}$ & $\begin{array}{l}\text { Schaan, } \\
2004\end{array}$ \\
\hline $\begin{array}{l}\text { Belém (M17) Os } \\
\text { Camutins }\end{array}$ & Denise Pahl Schaan & & $\mathrm{X}$ & Joanes Pintado (Urna 16) & $\begin{array}{l}\text { Ossos, um pequeno vaso, manchas de } \\
\text { carvão, fragmentos. }\end{array}$ & $\begin{array}{l}\text { Schaan, } \\
2004\end{array}$ \\
\hline
\end{tabular}




\begin{tabular}{|c|c|c|c|c|c|c|}
\hline \multirow{2}{*}{ Sítio } & \multirow{2}{*}{ Coletor } & \multicolumn{2}{|c|}{ Tipo de tanga } & \multirow{2}{*}{ Tipo de urna } & \multirow{2}{*}{ Material associado } & \multirow{2}{*}{ Referência } \\
\hline & & $\begin{array}{c}\text { C/ } \\
\text { Grafismos }\end{array}$ & Monocromática & & & \\
\hline $\begin{array}{l}\text { Belém (M17) Os } \\
\text { Camutins }\end{array}$ & Denise Pahl Schaan & $\mathrm{X}$ & & Joanes Pintado & ------ & $\begin{array}{l}\text { Schaan, } \\
2004\end{array}$ \\
\hline Camutins (Os Camutins) & $\begin{array}{l}\text { Victor Bandeira e } \\
\text { Françoise Carel- } \\
\text { Bandeira }\end{array}$ & $\mathrm{X}$ & & Joanes Pintado G1. & Sem informações & $\begin{array}{l}\text { Troufflard, } \\
2010\end{array}$ \\
\hline Camutins (Os Camutins) & $\begin{array}{l}\text { Victor Bandeira e } \\
\text { Françoise Carel- } \\
\text { Bandeira }\end{array}$ & $\mathrm{X}$ & & $\begin{array}{l}\text { Arari exciso vermelho } \\
\text { G2 }\end{array}$ & Sem informações & $\begin{array}{l}\text { Troufflard, } \\
2010\end{array}$ \\
\hline Panellas & Antonio Mordini & $\mathrm{X}$ & & $\begin{array}{l}\text { Associada a uma } \\
\text { antropomórfica com } \\
\text { gravuras }\end{array}$ & Sem informações & $\begin{array}{l}\text { Palmatary, } \\
1950\end{array}$ \\
\hline Panellas & Antonio Mordini & & $\mathrm{X}$ & $\begin{array}{c}\text { Associada a uma urna } \\
\text { antropomórfica com } \\
\text { gravuras }\end{array}$ & Sem informações & $\begin{array}{l}\text { Palmatary, } \\
1950\end{array}$ \\
\hline Teso dos Bichos & José S. Lourenço & $\mathrm{X}$ & & $\begin{array}{c}\text { Urna branca com } \\
\text { incisões retocadas de } \\
\text { vermelho }\end{array}$ & $\begin{array}{l}\text { Esqueleto desarticulado, estatueta } \\
\text { chocalho. }\end{array}$ & $\begin{array}{l}\text { Roosevelt, } \\
1991\end{array}$ \\
\hline
\end{tabular}

*Devido ao fato de a tipologia "Joanes Pintado", conforme proposta por Meggers e Evans(1957), englobar tipos de urnas morfologicamente distintos, optamos por acrescentar na tabela juntamente com o termo, quando a identificação foi possível, as abreviações G1 (grupo 1) e G2 (grupo 2) para diferenciar os tipos, referindo-se às tipologias apresentadas por Barreto para estes tipos de urnas. Deste modo, G1 refere-se a urnas cujo corpo constitui um personagem específico e que, geralmente, é composta por elementos plásticos e pintados, enquanto G2 refere-se a urnas com dimensões médias, formas globulares, e pintadas com grafismos semelhantes. 
ANEXO 2. Ficha de análise utilizada neste dissertação. 


\begin{tabular}{|c|c|c|}
\hline \multicolumn{3}{|c|}{ FICHA DE ANALISE } \\
\hline \multicolumn{3}{|c|}{ A.DOCUMENTAÇÃO } \\
\hline $\begin{array}{l}\text { NÚMERO DE } \\
\text { REGISTRO }\end{array}$ & & \\
\hline \multicolumn{3}{|c|}{ B.DESCRIÇÃO GERAL } \\
\hline INTEGRIDADE & \multicolumn{2}{|l|}{ ( ) ÍNTEGRA ( )INCOMPLETA ( )FRAGMENTO } \\
\hline CONSERVAÇÃO & \multicolumn{2}{|c|}{ ( ) PADRÕES PRESERVADOS ( ) PADRÕES APAGADOS ( ) PADRÕES SEMI PRESERVADOS } \\
\hline $\begin{array}{l}\text { ALTERAÇÕES } \\
\text { SUPERFICIAIS }\end{array}$ & \multicolumn{2}{|c|}{ ( ) NÃO ( ) SIM （）PERDA DE POLICROMIA（）DESCAMAÇÃO } \\
\hline RESTAURO & \multicolumn{2}{|c|}{$\begin{array}{l}\text { ( ) SIM ( )NÃO TIPO: ( ) REINTEGRAÇÃO CROMÁTICA ( ) PREENCHIMENTO ( ) COLAGEM DE } \\
\text { FRAGMENTOS }\end{array}$} \\
\hline MORFOLOGIA & \multicolumn{2}{|l|}{ ( )1 ( )2 ( )3 } \\
\hline $\begin{array}{l}\text { DIMENSÕES } \\
\text { DA PEÇA }\end{array}$ & \multicolumn{2}{|l|}{ ALTURA（）CM LARGURA（）CM } \\
\hline ESPESSURA & \multicolumn{2}{|l|}{ ( ) CM } \\
\hline $\begin{array}{l}\text { QUANTIDADE } \\
\text { DE CAMPOS } \\
\text { GRÁFICOS } \\
\end{array}$ & \multicolumn{2}{|l|}{() 1() 2() 3() 4() $5($ )6( )7 } \\
\hline \multicolumn{3}{|c|}{ C.SINAIS DE USO } \\
\hline $\begin{array}{l}\text { DESGASTE DOS } \\
\text { ORIFICIOS }\end{array}$ & \multicolumn{2}{|l|}{ ( ) SIM ( ) NÃO } \\
\hline \multicolumn{3}{|c|}{ D.PINTURA } \\
\hline $\begin{array}{l}\text { COR DO } \\
\text { ENGOBO }\end{array}$ & ( ) CREME ( ) BRANCO OUTRO $(. . . . . . . . . . . .)$. & MUNSELL: \\
\hline $\begin{array}{l}\text { COR DOS } \\
\text { GRAFISMOS }\end{array}$ & ( ) VERMELHO ( ) MARROM ( ) PRETO OUTRO (...............) & MUNSELL: \\
\hline $\begin{array}{l}\text { QUANTIDADE } \\
\text { DE CORES }\end{array}$ & \multicolumn{2}{|l|}{ ( ) 2 CORES ( ) 3 CORES ( )MAIS [..............] } \\
\hline \multicolumn{3}{|l|}{$\begin{array}{l}\text { CAMPOS } \\
\text { GRÁFICOS }\end{array}$} \\
\hline \multicolumn{3}{|c|}{ BANDA 1} \\
\hline $\begin{array}{l}\text { PADRÃO } \\
\text { GRÁFICO }\end{array}$ & \multicolumn{2}{|l|}{ ( ) $1[\ldots .],.($ )2, ( )3, ( )4, ( )5, ( ) 6} \\
\hline $\begin{array}{l}\text { TIPO DE } \\
\text { PADRÃO } \\
\text { BANDA }\end{array}$ & \multicolumn{2}{|l|}{() 1() 2() 3() 4() 5() 6() 7} \\
\hline \multicolumn{3}{|l|}{$\begin{array}{l}\text { PRINCIPAIS } \\
\text { ELEMENTOS E } \\
\text { MOTIVOS } \\
\end{array}$} \\
\hline ELEMENTOS & \multicolumn{2}{|c|}{$\begin{array}{l}\text { ( )ASPA ( ) CRUZ ( ) ESPIRAIS ( )GANCHOS ( )HEXÁGONO ( )LOSANGO ( )PENTÁGONOS ( ) } \\
\text { RETÂNGULOS ( ) SETAS ( )TS ( )TRIÂNGULOS ( )TRIÂNGULOS ELABORADOS ( )VOLUTAS }\end{array}$} \\
\hline MOTIVOS & \multicolumn{2}{|c|}{ 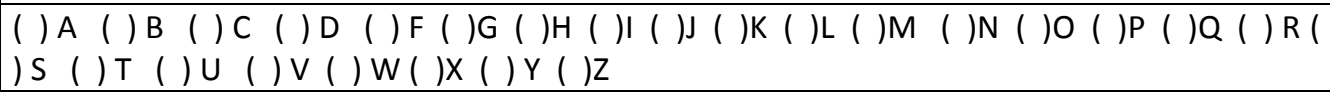 } \\
\hline
\end{tabular}




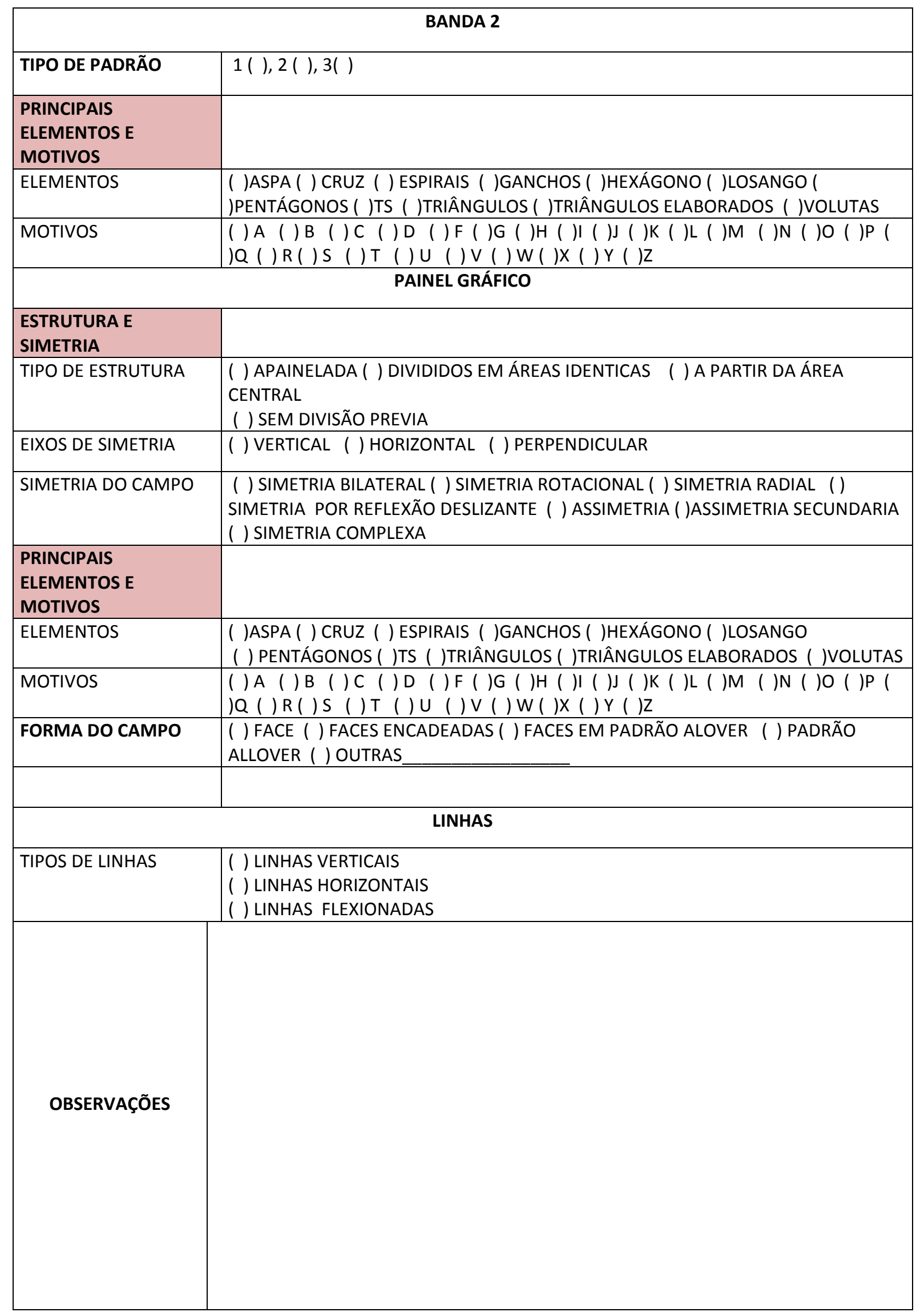


